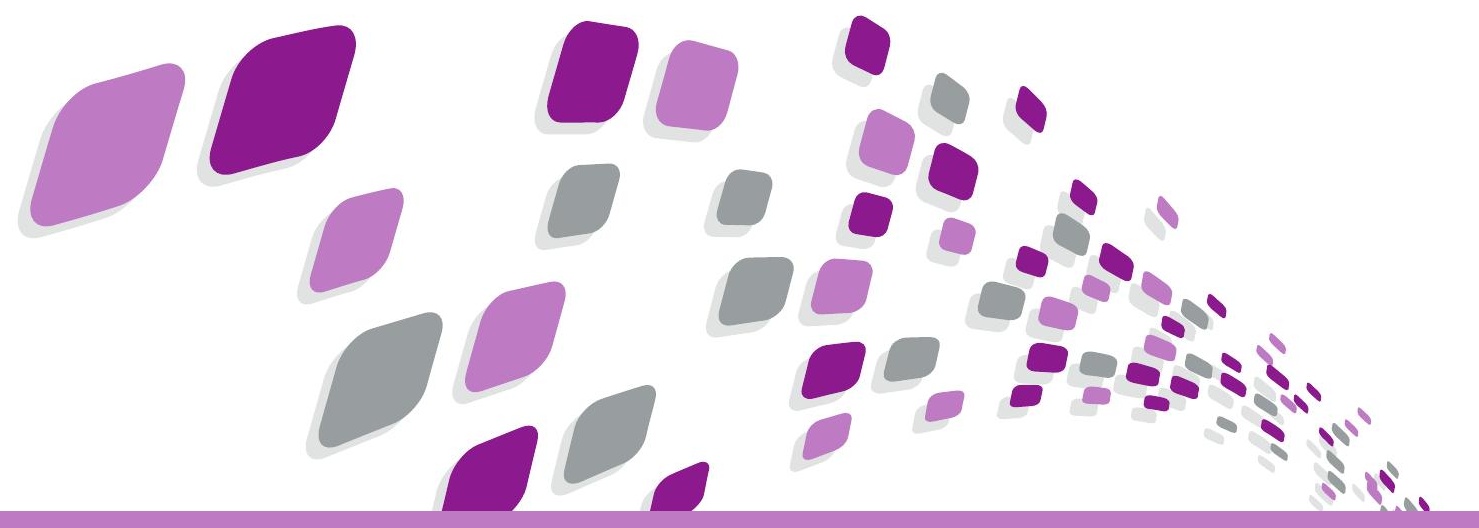

\title{
Inclusäo educacional
}

\section{para surdas: \\ tons e cores da formação continuada de professores no exercício profissional}

Lázara Cristina da Silva Marisa Pinheiro Mourão Wender Faleiro da Silva organizadoras

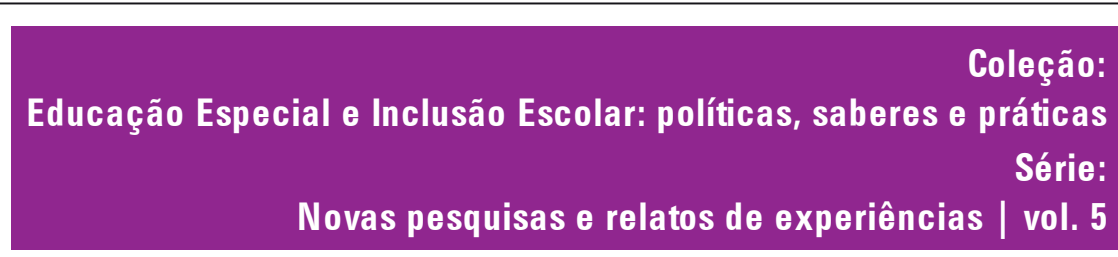

$$
E D \cup F U
$$


ATENDIMENTO EDUCACIONAL PARA SURDOS:

TONS E CORES DA FORMAÇÃO CONTINUADA DE PROFESSORES NO EXERCÍCIO PROFISSIONAL 
PRESIDENTE DA REPÚBLICA

Dilma Rousseff

MINISTRO DA EDUCAÇÃO

Aloizio Mercadante

SECRETÁRIA DE EDUCAÇÃO CONTINUADA, ALFABETIZAÇÃO, DIVERSIDADE E INCLUSÃO - SECADI

Macaé Maria Evaristo dos Santos

DIRETORIA DE POLÍTICAS PEDAGÓGICAS DE EDUCAÇÃO ESPECIAL

Martinha Clarete Dutra dos Santos

UNIVERSIDADE FEDERAL DE UBERLÂNDIA - UFU REITOR

Elmiro Santos Resende

VICE-REITOR

Eduardo Nunes Guimarães.

FACULDADE DE EDUCAÇÃO FACED/UFU DIRETOR Marcelo Pereira Soares da Silva

CENTRO DE ENSINO, PESQUISA, EXTENSÃO E ATENDIMENTO EM EDUCAÇÃO ESPECIAL CEPAE/UFU

Lázara Cristina da Silva
CURSO DE APERFEIÇOAMENTO

EM ATENDIMENTO EDUCACIONAL

ESPECIALIZADO PARA ALUNOS

SURDOS

Lázara Cristina da Silva

COORDENAÇÃO DE TUTORIA

Jane Eyre Bandeira de Lavôr Gonçalves

COORDENAÇÃO PEDAGÓGICA

DO CEaD

Marisa Pinheiro Mourão

SUPORTE TECNOLÓGICO

Alberto Dumont Alves Oliveira

Otaviano Ferreira Guimarães

João Vitor da Silva Alves

APOIO PEDAGÓGICO E

ADMINISTRATIVO

Jane Eyre Bandeira de Lavôr Gonçalves Karla Vanessa da Silva Giló

Maria Ivonete Ramos

REVISÃO TEXTUAL

Valdete Aparecida Borges Andrade

TRADUÇÃO E INTERPRETAÇÃO DOS VÍDEOS PARA LIBRAS

Márcia Dias Lima 


\section{Atendimento educacional para surdos: tons e cores da formação}

continuada de professores no exercício profissional

Lázara Cristina da Silva Marisa Pinheiro Mourão

Wender Faleiro da Silva

Organizadores

Coleção:

Educação Especial e Inclusão Escolar:

Políticas, Saberes e Práticas.

Série:

Novas pesquisas e relatos de experiências

Volume 5

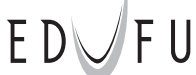


REITOR

Elmiro Santos Resende

\author{
Vice-Reitor Diretora da Edufu \\ Eduardo Nunes Guimarães Joana Luiza Muylaert de Araújo
}

Conselho Editorial

\author{
Alessandro Alves Santana \\ Lília Gonçalves Neves \\ Carlos Eugênio Pereira \\ Luiz Carlos de Laurentiz \\ Cibele Crispim \\ Luiz Fernando Moreira Izidoro \\ Francisco José Torres de Aquino \\ Sílvio Carlos Rodrigues
}

Guilherme Fromm

Dados Internacionais de Catalogação na Publicação (CIP)

Sistema de Bibliotecas da UFU, MG, Brasil.

A864e Atendimento educacional para surdos : tons e cores da educação continuada de professores no exercício profissional / Lázara Cristina da

Silva, Marisa Pinheiro Mourão, Wender Faleiro da Silva (organizadores).

- Uberlândia: EDUFU, 2014.

208 p. : il. - (Educação Especial e Inclusão Escolar: Políticas, Saberes e

Práticas ; série Novas pesquisas e relatos de experiências, v. 5)

Inclui bibliografia.

ISBN: 978-85-7078-355-4.

1. Educação. 2. Surdos - Educação. 3. Professores - Formação. I.

Silva, Lázara Cristina da. II. Mourão, Marisa Pinheiro. III. Silva, Wender

Faleiro da. IV. Título.

\title{
Equipe de realização
}

Editora de publicações

Projeto gráfico e capa

Diagramação
Maria Amália Rocha

Ivan da Silva Lima

Natália Borba

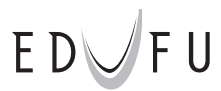

Editora da Universidade Federal de Uberlândia

Av. João Naves de Ávila, 2121 - Campus Santa Mônica - Bloco 1S - Térreo

Cep 38408-100 - Uberlândia - Minas Gerais

Tel: (34) 3239-4293

www.edufu.ufu.br 


\section{Sumário}

7 Apresentação

Lázara Cristina da Silva

Wender Faleiro da Silva

Marisa Pinheiro Mourão

\section{CAPÍTULO I}

13 Formação de professores para o atendimento educacional

especializado: uma necessidade, um direito

Geovana Ferreira Melo Teixeira

\section{CAPÍTULO II}

27 Educação a distância na lógica da mundialização do capital: limites e possibilidades para a qualificação profissional em serviço

Cinval Filho dos Reis

Jane Maria dos Santos Reis

\section{CAPÍTULO III}

47 Ensino da Língua Brasileira de Sinais e formação de professores a distância

Marisa Pinheiro Mourão

Arlete Aparecida Bertoldo Miranda

\section{CAPÍTULO IV}

73 Educação de alunos surdos na perspectiva inclusiva: limites e possibilidades nas escolas públicas brasileiras

Ana Carolina Caetano Arantes

Vilma Aparecida de Souza

\section{CAPÍTULO V}

93 As variáveis - estrutura, diálogo e autonomia - na relação didático-pedagógica de curso on-line: otimizando a formação e potencializando a distância transacional

Eleodora S. Leonardi

Eliamar Godoi

Wender Faleiro 


\section{CAPÍTULO VI}

119 A política nacional de formação continuada de professores e a educação especial: compreendendo a acessibilidade.

Lázara Cristina da Silva

Andréa Pires Dayrell da Cunha Pereira

Letícia Rodrigues de Castro

Ludmile Cristine Mendes Santos

\section{CAPÍTULO VII}

133 A Libras no atendimento educacional especializado: base para o letramento em Libras e em Português

Nelma Cristina de Carvalho

Cristina B. F. de Lacerda

\section{CAPÍTULO VIII}

143 Atendimento educacional especial e o estudante surdo: o desafio da aprendizagem da Libras em diferentes ambientes

Lara Ferreira dos Santos

Cristina Broglia Feitosa de Lacerda

\section{CAPÍTULO IX}

1650 atendimento educacional especializado no processo de inclusão: experiências de uma escola municipal

Nathália Freitas Santos Nunes

Viviane Prado Buiatti

\section{CAPÍTULO IX}

189 Contribuições do curso de aperfeiçoamento em atendimento educacional especializado para pessoas surdas: concepções dos cursistas da turma II, da segunda edição do curso

Fernanda Duarte

Viviane Chaves 
A construção de um espaço educacional com horizontes inclusivos demanda a modificação de estruturas físicas e mentais historicamente construídas. Para além das mudanças estruturais da escola, há urgência na mudança atitudinal e conceitual dos profissionais envolvidos no processo de escolarização. Para tanto, a formação inicial e continuada de professores apresenta-se como uma demanda real e urgente.

Neste sentido, cabe às instituições formadoras assumirem seu papel e o compromisso social com a garantia de inserção nos currículos formativos de temáticas que ampliem e modifiquem a atuação desses profissionais no sentido de romper com modelos classificatórios e excludentes que cerceiam as condições de desenvolvimento e aprendizagem das crianças em idade escolar.

São muitas as dificuldades encontradas no tocante à garantia dos direitos relacionados à escolarização das pessoas com deficiências, transtornos globais do desenvolvimento e altas habilidades/superdotação, no entanto, a acessibilidade à escola e aos seus diversos espaços de convívio coletivo e de ensino e aprendizagem (questões relacionadas à acessibilidade arquitetônica), ao currículo trabalhado na instituição escolar (questões relacionadas à acessibilidade comunicacional, atitudinal e conceitual) são desafios que se apresentam a todos.

Neste sentido, este livro é resultado do trabalho de um grupo de profissionais preocupado com a formação docente e a escolarização das pessoas com deficiências, transtornos globais do desenvolvimento e altas habilidades/superdotação, membros do Grupo de Estudos e Pesquisa em Políticas e Práticas em Educação Especial - GEPEPES, nas linhas de Educação a Distância e Educação Especial, de Educação de Pessoas Surdas e Ensino de Língua Brasileira de Sinais - Libras, e de Políticas e Educação Especial. É também parte do compromisso assumido junto ao Ministério da Educação por meio da Secretaria de Educação Continuada, Alfabetização, Diversidade e Inclusão/Diretoria de Políticas Pedagógicas de Educação Especial (MEC/SECADI/DPEE), como publicização das atividades de pesquisa realizadas nas edições do Curso de Extensão em Aperfeiçoamento em Atendimento Educacional Especializado para Surdos.

O GEPEPES foi criado em 2009 com o objetivo de congregar pesquisadores na área da Educação Especial, para realização de estudos e pesquisas envolvendo políticas públicas, formação docente, metodologias de ensino, estudo de Língua Brasileira de Sinais etc., correlacionadas com o processo de escolarização do público da Educação Especial. Esse grupo 
possui oito linhas de trabalho, com cinquenta participantes. A dinâmica acontece de acordo com a coordenação de cada linha de estudo e pesquisa, constando de reuniões de trabalho, atividades de grupos de estudos, pesquisas coletivas, cursos de formação continuada de professores, de Libras, de intérpretes de Libras, de Braile, etc. Bienalmente o grupo organiza um evento na área da Educação Especial e inclusiva, para fomentar a divulgação de pesquisas, a troca de experiências, atualização das discussões da área.

Uma das atividades articuladas, envolvendo pesquisadores das três linhas citadas anteriormente, é a oferta em parceria com o Centro de Ensino, Pesquisa, Extensão e atendimento em Educação Especial - CEPAE, e a Faculdade de Educação da Universidade Federal de Uberlândia - UFU, com a Secretaria de Educação Continuada, Alfabetização, Diversidade e Inclusão - SECADI, do Ministério da Educação, de um Curso de Extensão na Rede Nacional de Formação Continuada de Professores em Educação Especial, o Curso de Aperfeiçoamento em Atendimento Educacional Especializado para Alunos Surdos, do qual vem o apoio financeiro para esta publicação.

A participação da UFU por meio do CEPAE nas atividades da Rede Nacional de Formação Continuada de Professores em Educação Especial teve início em 2008, com a oferta de um Curso "Professor e Surdez: Cruzando Caminhos, produzindo novos olhares", que durante os anos de 2008 e 2009 qualificou mil professores de todo o país que atuavam em salas de aula do ensino regular, em parceria com a Universidade Aberta do Brasil - UAB. Dessa participação também foram produzidos dois livros: um de material didático e o outro com resultados de pesquisas, envolvendo a experiência realizada. Dessa participação surgiu também a ideia e a necessidade da criação do GEPEPES.

No ano de 2011, os dois projetos do CEPAE/UFU foram aprovados novamente pela Rede Nacional de Formação Continuada de Professores em Educação Especial com o objetivo de, cada curso, capacitar 2.000 professores da rede pública de ensino regular do Brasil, ambos voltados para o Atendimento Educacional Especializado - AEE nas escolas regulares, sendo um para pessoas que estivessem interessadas no curso e o outro para estudantes surdos. Neste novo formato de cursos, não mais voltados para os professores de salas regulares, mas para a formação daqueles que estejam atuando no Atendimento Educacional Especializado regulamentado em 2008, pelo Decreto n.ำ 6.571, de 17 de setembro de 2008, revogado atualmente pelo Decreto n.․ 7.611, de 17 de novembro 2011.

0 Curso de Aperfeiçoamento em Atendimento Educacional Especializado para Alunos Surdos tem por objetivo oferecer formação 
continuada a distância, via web, para educadores que atendem ou pretendem atender alunos surdos na modalidade de Atendimento Educacional Especializado - AEE. A forma de interação e comunicação entre tutores e alunos foi efetivada, exclusivamente, no Ambiente Virtual de Aprendizagem - AVA Moodle.

Para a realização deste curso foi composta uma equipe de profissionais que trabalham diariamente na concepção, organização e disponibilização de atividades no AVA. Todos trabalham com a finalidade de tornar a experiência de formação dos cursistas significativa tanto no aspecto profissional quanto pessoal. 0 curso oferece espaço on-line totalmente acessível, com atividades que requerem a interação e a troca de ideias, registro e estudos, ferramentas para esclarecimentos de dúvidas e dificuldades. Cada edição do curso é composta por cinquenta turmas, com vinte alunos cada, envolvendo uma equipe de cinquenta tutores, dezessete professores pesquisadores, um coordenador geral e um de tutoria, além de outros profissionais que atuam na área administrativa e no apoio técnico.

Demarca-se, que este livro é resultado de atividades de pesquisadores do GEPEPES, tendo como corpus de estudo o Curso de Extensão em Aperfeiçoamento em Atendimento Educacional Especializado para Alunos Surdos, segunda edição realizado em 2012. Encontra-se organizado em nove capítulos.

No capítulo I, "Formação de Professores para o Atendimento Educacional Especializado: uma Necessidade, um Direito", a autora apresenta uma discussão sobre o processo de melhoria da formação inicial e continuada de professores, favorecendo o conhecimento e o aprimoramento das produções realizadas nos últimos anos, de forma contextual, geradas pelo momento político que vive a educação de modo geral e da Educação Inclusiva de modo específico.

O capítulo II, "Educação a Distância na Lógica da Mundialização do Capital: Limites e Possibilidades para a Qualificação Profissional em Serviço", os autores apresentam a EaD nos seus aspectos históricos, sua relação com a dinâmica do sistema capitalista, discutindo os sentidos que essa modalidade de ensino constrói na realidade educacional brasileira, principalmente na formação continuada de professores para atuação no Atendimento Educacional Especializado nas escolas brasileiras.

O capítulo III, "Ensino da Língua Brasileira de Sinais e a Formação a Distância", discute ações alternativas de formação docente, em que as Tecnologias da Informação e da Comunicação - TIC, podem se tornar uma ferramenta diferente e diversificada para atender as demandas da realidade educacional de um país de dimensões continentais como 
o Brasil, relaciona tais tecnologias ao ensino da Língua de Sinais para professores nas escolas públicas brasileiras, tendo como referência o material produzido no Libranet, curso que visa o ensino da Língua Brasileira de Sinais.

O capítulo IV "Educação de Alunos Surdos na Perspectiva Inclusiva: Limites e Possibilidades nas Escolas Públicas Brasileiras", tem como objeto de investigação a atual política de formação docente para a Educação Especial instituída pelos Cursos de Formação Continuada para Professores na área da Educação Especial/Inclusiva por meio da Rede Nacional de Formação de Professores em Educação Especial do Ministério da Educação, criada em 2008. 0 foco principal do estudo é o Curso de Atendimento Educacional Especializado para Alunos Surdos. As autoras procuram analisar os limites e as possibilidades encontradas na dinâmica do trabalho docente, em relação à educação de alunos surdos nas escolas públicas brasileiras, a partir das percepções dos professores que participaram de cursos de formação continuada na modalidade a distância, pela Plataforma Freire, em especial o curso "Atendimento Educacional Especializado para Pessoas Surdas - Turma I".

No capítulo V, "As variáveis - estrutura, diálogo e autonomia - na relação didático-pedagógica de curso on-line: otimizando a formação e potencializando a distância transacional", os autores apresentam uma análise da relação didático-pedagógica entre professores formadores e tutores do Curso de Atendimento Educacional Especializado para Alunos Surdos, ofertado pelo Centro de Ensino, Pesquisa, Extensão e Atendimento em Educação Especial - CEPAE/UFU. Esses autores objetivaram descrever e analisar as implicações da relação professor formador-tutor no desenvolvimento e desempenho do aluno em formação desse curso.

O capítulo VI, "A Política Nacional de Formação Continuada de Professores e a Educação Especial: compreendo a acessibilidade", apresenta resultados de uma pesquisa financiada pelas agências de fomento à pesquisa CNPq e Fapemig, que discute a Formação Continuada de Professores para o público da Educação Especial, focado no Atendimento Educacional Especializado - AEE dos cursos da Rede Nacional de Formação Continuada de Professores em Educação Especial da SECADI/ MEC. Este artigo trata, especificamente, da questão da acessibilidade presente nos cursos estudados na Rede Nacional de Formação Continuada de Professores em Educação Especial.

No capítulo VII, "A Libras no Atendimento Educacional Especializado: Base para o Letramento em Libras e em Português", as autoras abordam aspectos de uma experiência de ensino de Português escrito, realizada 
com um grupo de dezesseis adolescentes surdos, que frequentavam o sexto ao nono ano do ensino fundamental, em uma escola pública da rede regular. A experiência relatada poderá ser implementada em espaços de Atendimento Educacional Especializado - AEE.

No capítulo VIII, "Atendimento Educacional Especial e o Estudante Surdo: O Desafio da Aprendizagem da Libras em Diferentes Ambientes" as autoras apresentam uma proposta de trabalho de ensino de Libras e de Português como segunda língua, envolvendo um instrutor surdo. Além disso, apresentam e discutem atividades realizadas e contribuições para a aprendizagem do estudante surdo.

No penúltimo capítulo, "O atendimento educacional especializado no processo de inclusão: experiências de uma escola municipal”, resultado de uma pesquisa qualitativa, buscou discutir a inclusão escolar e o AEE, em uma escola municipal de Ituiutaba - $\mathrm{MG}$, oferecido às pessoas com deficiência, transtornos globais do desenvolvimento e altas habilidades/ superdotação. As autoras procuraram compreender e apreender o movimento do AEE nesta escola, conhecer a clientela atendida, compreender como se configura o trabalho da equipe e identificar a visão de professores e gestão sobre essa proposta, levantando suas concepções, estratégias e práticas para o desenvolvimento de competências no trabalho com essa população.

No último capítulo, "Contribuições do curso de aperfeiçoamento em Atendimento Educacional Especializado para pessoas surdas: concepções dos cursistas da turma II da segunda edição do referido curso", as autoras apresentam dados de uma pesquisa desenvolvida no curso de Pedagogia da Faculdade de Ciências Integradas do Pontal da Universidade Federal de Uberlândia - FACIP/UFU, com objetivo analisar as contribuições do Curso de Aperfeiçoamento em Atendimento Educacional Especializado para Pessoas Surdas, realizado no ano de 2011, nessa universidade, em parceria com o Centro Ensino, Pesquisa, Extensão e Atendimento em Educação Especial - CEPAE, na formação dos cursistas.

0 presente material apresenta diferentes olhares e possibilidades de se relacionar e compreender os processos de escolarização em um contexto de Educação Inclusiva, precisamente ao grupo de estudantes surdos, sinalizando para os profissionais da área grande contribuição no sentido de compreender sua realidade e agir sobre a mesma.

Lázara Cristina da Silva Wender Faleiro da Silva Marisa Pinheiro Mourão 


\section{CAPÍTULO I \\ FORMAÇÃO DE PROFESSORES PARA O ATENDIMENTO EDUCACIONAL ESPECIALIZADO: UMA NECESSIDADE, UM DIREITO}

Geovana Ferreira Melo Teixeira

Não há saber mais, nem saber menos, há saberes diferentes.

Paulo Freire

A análise apresentada neste artigo tem o objetivo de destacar a necessidade de formação inicial e continuada de professores, para o Atendimento Educacional Especializado - AEE. O professor, que é tomado como mobilizador de saberes profissionais bastante específicos, característicos da profissão docente, deverá ter em sua trajetória formativa e profissional a oportunidade de desenvolver-se profissionalmente, no sentido de construir e reconstruir seus saberes. Trata-se de uma pesquisa bibliográfica e documental que teve como ponto de partida o estudo da literatura referente a formação de professores e suas especificidades para o AEE, focalizando os saberes da docência.

A presente pesquisa partiu de um amplo acervo de fontes bibliográficas e teve como principal objetivo contribuir com os debates que evidenciam a formação de professores, numa perspectiva pluridimensional. Este trabalho insere-se neste contexto propício e fértil da produção acadêmico-científica, e visa ampliar os debates em torno da temática que tem como preocupação central investigar a necessidade de formação de professores para atuação no AEE. Este estudo pretende avançar no sentido de contribuir com o processo de melhoria da formação inicial e continuada de professores, além de favorecer o conhecimento e aprimoramento das produções realizadas nos últimos anos, apesar das limitações contextuais geradas pelo momento político que vive a educação de modo geral e da Educação Inclusiva de modo específico.

Os estudos têm destacado a importância de se analisar a questão formação como algo relevante. Pimenta (2000, p. 17) ressalta a importância "de ressignificar os processos formativos a partir da reconsideração dos saberes necessários à docência, colocando a prática pedagógica e docente escolar como objeto de análise".

0 AEE tem especificidades que devem ser contempladas ao longo da formação inicial e continuada, uma vez que essas especificidades 
demandam a capacidade do professor de mobilizar diferentes saberes. O AEE tem o compromisso de elaborar e organizar recursos pedagógicos e de acessibilidade capazes de promover o pleno desenvolvimento e participação dos alunos, considerando as suas necessidades específicas. As atividades desenvolvidas no AEE diferenciam-se daquelas realizadas na sala de aula comum, não sendo substitutivas à escolarização. Esse atendimento complementa e/ou suplementa a formação dos alunos com vistas à autonomia e à independência na escola e fora dela. São objetivos do AEE, conforme artigo Art. 3 do Decreto n.ำ 7611/2011:

I- prover condições de acesso, participação e aprendizagem no ensino regular e garantir serviços de apoio especializados de acordo com as necessidades individuais dos estudantes;

II- garantir a transversalidade das ações da educação especial no ensino regular;

III- fomentar o desenvolvimento de recursos didáticos e pedagógicos que eliminem as barreiras no processo de ensino e aprendizagem; e

IV- assegurar condições para a continuidade de estudos nos demais níveis, etapas e modalidades de ensino.

Os objetivos citados acima, para serem plenamente alcançados, exigem que os professores tenham uma formação sólida do ponto de vista teórico-metodológico, especialmente, no que se refere a "prover condições de acesso, participação e aprendizagem no ensino regular e garantir serviços de apoio especializados de acordo com as necessidades individuais dos estudantes". Para prover tais condições, o professor deverá ter profundo conhecimento a respeito das dificuldades apresentadas pelos alunos e buscar formas concretas de amenizá-las. A partir da constatação referente às especificidades do $\mathrm{AEE}$, fica evidente a responsabilidade dos cursos de formação de professores no sentido de considerar os diferentes saberes no processo formativo, principalmente nos cursos de formação inicial, em que os licenciandos começam a ter os primeiros contatos com a profissão.

A formação de professores para atuar no AEE deverá organizar-se com o objetivo de possibilitar aos professores a construção dos saberes docentes. No intuito de desenvolver um processo formativo que contribua para o desenvolvimento do aluno com deficiência, os professores devem ser amplamente preparados para lidarem com a diversidade e a crescente demanda do atendimento especializado.

Além disso, o professor deverá ter em seu processo formativo a oportunidade de desenvolver a aprendizagem de linguagens e de códigos 
específicos de comunicação e sinalização. Outro aspecto a ser contemplado, refere-se à necessidade de adequações e produção de materiais didáticos e pedagógicos, tendo em vista as necessidades específicas dos alunos, o que requer dos professores o domínio de diferentes saberes a serem construídos no contexto de sua formação. Embora as atividades do AEE se diferenciem das realizadas em salas de aula, o professor deverá promover ampla articulação entre tais atividades com a finalidade de alcançar a melhoria da qualidade da formação dos alunos e de suas capacidades.

\section{Especificidades da formação de professores para o AEE: em foco os saberes docentes}

A Conferência Mundial sobre Educação para Todos realizada em Jomtien, na Tailândia no ano de 1990, constitui-se em um marco para a consolidação dos processos de inclusão escolar. Outro marco significativo, no âmbito dos direitos sociais, é a Declaração de Salamanca ocorrida em 1994. Esse documento concebe a formação inicial essencial para que os professores possam ter a oportunidade de compreender a deficiência e suas demandas, de forma que permita entender como as escolas podem contribuir para o desenvolvimento pleno de alunos com deficiência. A discussão centrou-se na necessidade de desenvolver nos professores diferentes habilidades necessárias para a inclusão de alunos com deficiência. Além disso, a declaração lança luzes nos saberes e aptidões imprescindíveis para a consolidação de uma pedagogia da inclusão, quais sejam: a capacidade de analisar as necessidades educativas dos alunos, de promover a adaptação dos conteúdos dos programas de estudo, de personalizar os procedimentos pedagógicos, de perceber a importância de trabalhar em conjunto com especialistas e pais, além de recorrer à ajuda da tecnologia para o aprimoramento do processo educacional.

A proposta para a formação de professores para atuar no AEE busca romper com o modelo da racionalidade técnica ${ }^{1}$ e as abordagens psicológicas que se centravam nos processos de aprendizagem. Tais

\footnotetext{
${ }^{1}$ A racionalidade técnica, conforme Giroux (1997), está calcada em ideologias instrumentais, que reduzem os professores a técnicos, de modo que, imersos na burocracia escolar, estejam incumbidos de "administrar e implementar programas curriculares, mais do que desenvolver ou apropriar-se criticamente de currículos que satisfaçam objetivos pedagógicos específicos." Contrapondo-se a esse modelo, Giroux reafirma a ideia de que a docência é um trabalho intelectual e não puramente técnico. Dessa forma, será preciso encarar os professores como "intelectuais transformadores", o que significa conferir ao exercício da docência a dimensão política (GIROUX, 1997, p. 161).
} 
modelos não mais satisfazem as inquietações dos pesquisadores na área educacional, e isso faz com que se volte um olhar diferente para a problemática da educação e, especificamente, para a docência no AEE. Nessa perspectiva, busca-se compreender o professor como sujeito histórico, dotado de subjetividades e intencionalidades. Nesse sentido, o saber docente vem sendo utilizado como importante categoria de análise, que busca desvelar o entendimento da cultura escolar, da prática pedagógica, enfim, dos saberes que os professores utilizam em seu cotidiano no AEE.

Para o desenvolvimento de nossa análise,é importante compreender o conceito de formação no sentido mais amplo, para que possamos refletir sobre o papel das políticas públicas que regem as instituições formadoras de professores. Parece-nos conveniente lembrar que,

a formação, encarada do ponto de vista do aprendente, torna-se um conceito gerador em torno do qual vêm agrupar-se, progressivamente, conceitos descritivos: processos, temporalidade, experiência, aprendizagem, conhecimento e saber-fazer, temática, tensão dialética, consciência, subjetividade, identidade. Pensar a formação [..] é evidentemente, não ignorar o que dizem as disciplinas das ciências do humano (Josso, 2004, p. 38).

A complexidade do processo de formação, particularmente da formação de professores para atuar no AEE, envolve aspectos, tais como: sociais, políticos, filosóficos e culturais. Assim, a formação, tanto inicial quanto continuada, deverá atentar-se para o reconhecimento das diferenças dos alunos, e para a compreensão da aprendizagem como um processo construído em interação e cooperação do sujeito com o meio. Isso significa que o professor deverá ter condições de refletir continuamente sobre sua prática pedagógica no sentido de identificar e desenvolver estratégias de ensino capazes de contribuir para a superação dos obstáculos e dificuldades dos alunos. A gestão dos processos de aprendizagem no AEE requer do professor a capacidade de mobilizar diferentes saberes: disciplinares, pedagógicos, experienciais.

Genericamente, os saberes disciplinares referem-se aos conhecimentos da área específica de formação, ou seja, a um conhecimento que vai além da aquisição de informações. Os saberes disciplinares, conforme Gauthier (1998, p. 29), dizem respeito "aos saberes produzidos pelos pesquisadores e cientistas nas diversas disciplinas científicas, ao conhecimento por eles produzidos a respeito do mundo". Referem-se 
também ao conhecimento do conteúdo a ser transmitido, uma vez que só se poderá ensinar o que conteúdo que se domina (Gauthier, 1998, p. 29). 0 conhecimento tem como ponto de partida o trabalho cognitivo com as informações, mas não se reduz a este, porque envolve a reflexão e a produção de novas formas de desenvolver as capacidades intelectuais.

Os saberes pedagógicos estão diretamente relacionados à orientação para a prática profissional da docência, às teorias da educação, aos processos de ensino-aprendizagem e aos princípios da organização escolar. Gauthier (1998, p. 34) ressalta que os saberes pedagógicos são os menos desenvolvidos durante a formação dos professores o que se constitui em um problema, visto que são imprescindíveis à profissionalização do ensino. Para esse autor, "os saberes pedagógicos constituem um dos fundamentos da identidade profissional do professor". Autores como Bourdoncle, citado por Gauthier (1998, p. 71) assumem que o desenvolvimento de um repertório de saberes exclusivos, originais e científicos seria o suficiente para garantir a profissionalização do magistério. Assim, os signatários dessa visão admitem que "entre todas as profissões, o ensino é aquela que deveria estar assentada sobre um sólido núcleo de conhecimentos, considerando que o desenvolvimento e a transmissão de conhecimentos constituem a sua própria essência" (Gauthier, 1998, p. 71). De acordo com a especificidade das tarefas docentes, essa perspectiva seria incoerente, pois a aula em si é dotada de momentos inesperados e, por mais que seja planejada, o professor sempre lida com o inusitado no cotidiano escolar.

Os saberes da experiência são produzidos e apropriados ao longo da história de vida do professor, em sua prática pedagógica diária e nas relações entre os pares, entre professores e os alunos, entre a escola e sua organização, e entre os professores e os seus próprios saberes. Os saberes da experiência advêm da intervenção pedagógica do professor na escola, em suas turmas, na organização do trabalho pedagógico, em sua própria história de vida profissional e pessoal. Para Tardif (2002, p. 48) estes saberes "não provém das instituições de formação nem dos currículos. [...] não se encontram sistematizados em doutrinas ou teorias." Nesse sentido, o professor é ao mesmo tempo produtor e sujeito. Os saberes da experiência como diz Tardif (2002, p. 50) "[...] fornecem aos professores certezas relativas a seu contexto de trabalho na escola de modo á facilitar sua integração".

Diante dessa problemática é que se torna oportuno reavaliar os saberes que são importantes na formação inicial e continuada dos professores. É preciso romper com a cultura do "ensino porque sei", para "ensino porque sei e sei ensinar" e, assim, construir uma outra perspectiva 
que promova uma formação de professores pautada nos diferentes saberes: sólidos conhecimentos da área específica e igualmente sólidos conhecimentos da área pedagógica. De acordo com Roldão,

Os docentes transportam um déficit de afirmação profissional exatamente pela fragilidade da sua relação com o saber definidor da atividade e consequentemente definidor do nível de profissionalidade; possuem, usam e trabalham com saberes, mas, carecem de um saber próprio que os identifique e com que se identifiquem: ou vivem o saber como sinônimo dos conteúdos que ensinam, ou vivem o saber educativo na versão praticista divorciada da teorização e formalização que o saber educacional - que eles também não produzem - oferece no campo das ciências da educação, situada num outro mundo de produção saber que apenas a formação procura "ligar" mas com escasso sucesso na ruptura desta divergência paradigmática das duas culturas em presença (Roldão, 2005, p. 21-22).

Para a atuação em uma escola que se preocupa com as diferenças, faz-se ainda mais urgente compreender que o desenvolvimento de novas práticas pedagógicas deve ser construído à luz de referenciais teóricos consistentes, na articulação entre o saber (conhecimento específico), o saber ensinar (conhecimento pedagógico), e o saber ser (relações interpessoais). Nesse sentido, torna-se essencial que se construa um processo colaborativo entre gestores, professores da sala comum e professores do AEE. Será importante superar as dificuldades e obstáculos no sentido de promover na escola o trabalho conjunto, de maneira que os esforços sejam orquestrados em favor de uma Educação Inclusiva e de uma qualidade socialmente referenciada. A cultura de partilha de saberes deverá ser fortalecida e estimulada nos processos de formação inicial e continuada.

Se os professores não se identificam com o saber educativo, se não são eles que produzem esse saber, se não o percebem como essencial para o desempenho de sua função docente, este parece ser mais um dos desafios a serem enfrentados pelos cursos de formação de professores: atribuir sentido aos diferentes saberes. De acordo com Pereira (2000, p. 75), "é preciso romper com uma visão simplista de formação de professores, negar a ideia do docente como mero transmissor de conhecimentos e superar os modelos de Licenciatura que simplesmente sobrepõem o 'como ensinar' ao 'o que ensinar'". Esses desafios apontados para a formação de professores precisam ser considerados na elaboração e implementação de projetos pedagógicos de cursos de formação inicial e continuada. 
As pesquisas têm contribuído para uma melhor compreensão dos processos formativos de professores e dos saberes que caracterizam a profissão docente. 0 desenvolvimento desses estudos utiliza uma abordagem teórico-metodológica que permite ouvir as vozes dos professores, a partir da análise de suas histórias de vida, trajetórias profissionais, práticas pedagógica, etc. De acordo com Nóvoa (1995), esta outra roupagem da pesquisa educacional surge em oposição aos estudos anteriores que restringiam a profissão docente a um conjunto de regras, competências e técnicas prescritas, ou seja, que ignorava o professor como ser humano, o que acabou por gerar nos professores uma crise de identidade em decorrência da separação do eu pessoal e o eu profissional. As pesquisas atuais têm destacado o professor como figura central dos estudos, possibilitando uma abordagem mais abrangente, a partir de diferentes enfoques que têm como pressuposto os saberes profissionais, a identidade docente, a prática pedagógica, dentre outros aspectos ligados ao exercício da profissão docente.

As concepções de formação de professores a partir da ótica da capacitação, ou seja, da transmissão pura e simplesmente de conhecimentos prontos, para que os professores estivessem "treinados" para o exercício da docência, têm dado lugar a outra abordagem, a da análise das práticas docentes, enfatizando os saberes dos professores, como estes são mobilizados e construídos no cotidiano escolar.

Nesta perspectiva, compreender os processos formativos, as experiências, as trajetórias de vida, permite esclarecer uma série de questões que vão desde a forma como o professor ensina, ao modo como ele organiza os conteúdos, os procedimentos, até o modo como lida com os alunos e suas demandas de aprendizagem. Isso faz com que se valorize outro tipo de saber: o experiencial, aquele que brota da experiência, sendo validado por ela e que está diretamente ligado à maneira como o professor age, porque toma determinadas decisões e como se posiciona diante dos problemas cotidianos.

Para Tardif (2000, p. 13), é importante compreender a epistemologia da prática profissional como o "estudo do conjunto dos saberes utilizados realmente pelos profissionais em seu espaço de trabalho cotidiano para desempenhar todas as suas tarefas". A sala de aula passa a ser o lugar privilegiado de mobilização e construção de novos saberes que irão configurar o fazer docente em prol do pleno desenvolvimento dos alunos. Para este autor, 
A questão da epistemologia da prática profissional se encontra, evidentemente, no cerne do movimento de profissionalização. De fato, no mundo do trabalho, o que distingue as profissões das outras ocupações é, em grande parte, a natureza dos conhecimentos que estão em jogo (Tardif, 2002, p. 247).

No intuito de compreender melhor a configuração dos diferentes saberes, necessários à prática docente, temos como referência que os saberes profissionais são elaborados, incorporados no processo do fazer docente, que só têm sentido quando se considera o contexto em que essas práticas pedagógicas se constituem e são constituídas. Tardif (2000) nos alerta para o fato de que os saberes profissionais dos professores são plurais e heterogêneos, porque formam um repertório de conhecimento unificado. São, portanto, ecléticos e pluridimensionais. Assim, esses saberes profissionais estão a serviço da ação e é na prática que se tornam significativos. Além disso, Tardif (2000) pontua que o objeto de trabalho do docente são seres humanos, com ampla possibilidade de desenvolvimento e, consequentemente, os saberes dos professores trazem consigo a marca do humano. As dimensões éticas e estéticas na prática pedagógica dos professores passam a ser consideradas, pois essa prática implica em construção de valores, expectativas e relações interpessoais que vão tecendo a complexidade da trama que o processo de ensino aprendizagem produz, especialmente na realidade do AEE.

Este estudo nos revela que os cursos de formação inicial e continuada de professores precisam oportunizar a aprendizagem dos diferentes saberes, para que os professores possam exercer sua tarefa, bastante complexa, da melhor maneira possível, pois, "ensinar supõe aprender a ensinar, ou seja, aprender a dominar progressivamente os saberes necessários à realização do trabalho docente" (Tardif, 2002, p. 20).

É no contexto da formação inicial e continuada que os professores devem ter a oportunidade de construir os diferentes saberes que os identificam enquanto profissional da docência em toda sua complexidade. Ser professor requer uma multiplicidade de atitudes que ultrapassam a previsibilidade. É preciso aprender a lidar diariamente com o inesperado, os conflitos, as individualidades, a adversidade, e isso requer um tempo de formação para além dos limites das instituições formativas.

Gauthier (1998, p. 24) ressalta que é possível reconhecer uma profissão "principalmente pela posse de um saber específico formalizado e adquirido numa formação de tipo universitário". Nesse sentido, a responsabilidade dos cursos de formação de professores consiste, 
principalmente, em propiciar a aquisição de saberes de diferentes ordens. Pois, o saber, apesar de ser pessoal, modifica-se com a experiência e se constitui a partir da interação com outras pessoas, evolui, transforma-se e vai se aprimorando constantemente. Barth, citada por Fiorentini (2001, p. 322) afirma que

o saber não é linear. Não se constrói como um prédio onde se deve necessariamente começar pela base e acabar pelo teto [...]. 0 nosso saber é o sentido que damos à realidade observada e sentida num dado momento. Existe no tempo como uma paragem, uma etapa. Está em constante transformação, em perpétuo movimento, tal como uma sinfonia inacabada.

Portanto, será necessário um contexto propício e fértil para a elaboração, interpretação e compreensão dos saberes que configuram a prática pedagógica, o que permitirá ampliar, cada vez mais, os saberes que já estão construídos e que estão sempre em movimento. Nessa direção, Carr e Kemmis (1988, p. 61) consideram que

0 saber do professor proporciona um ponto de partida para a reflexão crítica. Simplesmente, não pode dar-se por pronto ou sistematizado na teoria, nem tornar-se definitivo na prática. E isto não ocorre porque o saber do professor é menos exigente que o de outros, senão porque os atos educativos são atos sociais e, portanto, reflexivos, historicamente localizados, e abstraídos de contextos intelectuais e sociais concretos. De tal maneira que a educação deve estar de acordo com as circunstâncias históricas, os contextos sociais e os diversos entendimentos dos protagonistas durante o encontro educativo ${ }^{2}$.

Esse posicionamento dos autores nos faz compreender a prática pedagógica como uma verdadeira praxis ${ }^{3}$, momento em que teoria e prática são absolutamente indissociáveis. Polarizar na formação inicial e continuada de professores, dando ênfase ora na teoria ora na prática seria cometer um equívoco. É importante manter, durante todo o curso de formação, momentos em que teoria e prática se harmonizem, se completem, se concluam, permitindo aos estudantes compreender seu

\footnotetext{
${ }^{2}$ Tradução nossa.

${ }^{3} \mathrm{Na}$ filosofia marxista, a palavra grega práxis é usada para designar uma relação dialética entre o homem e a natureza, na qual o homem, ao transformar a natureza com seu trabalho, transforma a si mesmo. (In: Dicionário Básico de Filosofia. Zahar, p. 219).
} 
processo formativo enquanto espaço fecundo de produção e apropriação de saberes de diferentes ordens.

Gauthier (1998, p. 28) nos alerta para o fato de que a formação de professores deve ser concebida como o espaço para a mobilização de vários saberes que formam uma espécie de reservatório no qual o professor se abastece para responder às exigências específicas de sua situação concreta de ensino. Nesse sentido, reconhecemos a escola e a sala de aula como espaços de produção e mobilização de saberes. Tardif (2000) também corrobora a ideia da importância da formação inicial e acentua a responsabilidade das instituições formadoras de professores. Para o autor,

Todo saber implica um processo de aprendizagem e de formação; e, quanto mais um saber é desenvolvido, formalizado, sistematizado, como acontece com as ciências e os saberes contemporâneos, mais se revela longo e complexo o processo de aprendizagem que exige, por sua vez, uma formalização e uma sistematização adequadas (Tardif, 2002, p. 218).

A profissão docente implica saberes, o que demanda aos cursos de formação inicial e continuada de professores compreender como esses saberes são produzidos, integrados e utilizados na prática. A docência é assim entendida como um ofício pleno de saberes que a caracterizam (cf. Gauthier, 1988, p. 28). Entendemos que a questão dos saberes docentes é um tema bastante polêmico e requer análises aprofundadas para sua compreensão. Optamos, neste estudo, por assumir os saberes docentes enquanto conhecimentos construídos pelo professor e que estão a serviço de sua prática profissional. Os saberes, afirma Charlot (2000, p. 62), são construídos em "uma história coletiva que é a da mente humana e das atividades do homem e está submetido a processos coletivos de validação [...]. Como tal é produto de relações epistemológicas entre os homens".

Alguns estudos, como o de Kassar (2006), Bueno (1999), Padilha (2001), propõem que os processos de formação inicial e continuada de professores para atuar no AEE sejam pautados pelo suporte à inclusão. Os referidos autores alertam para a necessidade de uma formação que habilite o professor especializado para uma adequação da prática pedagógica no contexto escolar pautada nas dificuldades dos alunos. Além do atendimento às singularidades decorrentes da deficiência, o professor deverá desenvolver um trabalho cooperativo com a família, a escola e a comunidade, em consonância com o projeto pedagógico, o que requer a construção de diferentes saberes da docência. 
A compreensão dos saberes desenvolvidos nos cursos de formação de professores permite ampliar o entendimento das práticas formativas desses cursos e o perfil de profissionais que está sendo formado. Os saberes são considerados, portanto, como o resultado de uma produção histórica e social, fruto de uma interação entre os sujeitos (professores) e seus processos educativos. Os saberes estão em constante movimento e passam por elaborações e reelaborações na medida em que haja necessidade.

\section{Possíveis considerações...}

0 estudo desenvolvido evidencia que a formação de professores para atuar no AEE consiste em um desafio, uma vez que as políticas públicas de formação inicial e continuada ainda caminham a passos lentos rumo à melhoria do trabalho pedagógico desenvolvido nas escolas. Além disso, são poucas as instituições escolares que se encontram totalmente preparadas para dar respostas eficazes à diferença de aprendizagem dos alunos.

No entanto, não se pode negar que as políticas de inclusão estão se consolidando e tornam-se perceptíveis, principalmente, com relação à preocupação crescente das escolas em aprimorar o atendimento especializado e oferecer as condições de aprendizagem a todos os alunos, independentemente de suas demandas e possíveis deficiências.

As escolas, que se organizam com base no princípio da inclusão, têm envidado esforços para construírem práticas que respondam às demandas de seus alunos. 0 cotidiano escolar vem se constituindo como um espaço privilegiado de reflexões sobre a necessidade de Atendimento Educacional Especializado que demanda dos processos de formação docente a construção de saberes capazes de prover os professores de atitudes proativas para a inclusão dos alunos com deficiência, cujo desenvolvimento pleno deve ser prioridade.

Uma escola inclusiva tem como princípios a compreensão das diferenças dos alunos, pautada na concepção de que a aprendizagem terá como finalidade maior o desenvolvimento de sujeitos autônomos. Nesse sentido, os processos formativos devem propiciar ao professor a construção de ferramentas que lhes permitam promover e ampliar a capacidade de aprendizagem do aluno a partir de diferentes perspectivas didático-pedagógicas.

Os professores, ao serem estimulados a desenvolverem o olhar atento e a escuta sensível a respeito das questões que envolvem as 
dificuldades de aprendizagem dos alunos e suas especificidades, terão uma visão de conjunto da realidade em que atuam, ou seja, uma maior percepção de toda a problemática que envolve a educação e o processo de ensino e aprendizagem no AEE. Esse exercício da prática refletida, alimentada pela teoria, dá origem a novas finalidades, pois os professores serão capazes de produzir novas percepções sobre a escola e também sobre as dificuldades de seus alunos, que os farão enxergar e compreender a realidade de maneira mais aprofundada e extensa.

Nos processos formativos, a prática investigativa é essencialmente válida para a formação dos professores. Ao trazer questões do cotidiano escolar para serem refletidas coletivamente, é possível articular teoria e prática, e focalizar aspectos inerentes à prática pedagógica em sua totalidade. A escola passa a ser vista como um local onde existe a interação entre vários sujeitos com suas diferenças, necessidades, possibilidades intermediadas por espaços e lógicas diferenciadas, enfim, passa a ser vista como um local que envolve uma multiplicidade de ações, as quais devem ser pensadas à luz de referenciais teóricos, pois os aspectos dessa realidade precisam ser aprofundados.

O desafio que ainda permanece nas escolas brasileiras consiste na necessidade de concretizar práticas pedagógicas que sejam capazes de transformar a realidade escolar no sentido de possibilitar, além da acessibilidade, a permanência de todas as crianças, jovens e adultos, para que possam se desenvolver plenamente por meio do acesso aos bens culturais historicamente acumulados pela humanidade.

As reflexões realizadas, além da análise da literatura, apontam para urgência de se incluir nos projetos pedagógicos dos cursos de pedagogia e demais licenciaturas, aspectos referentes aos fundamentos e práticas de Educação Inclusiva, gestão da sala de aula, além dos saberes docentes para o AEE.

Especialmente nos cursos de formação inicial deverá ser contemplada a reflexão sobre a instituição escolar: crenças, valores e hábitos que constituem o cotidiano da escola, o modo como os professores, pais e gestores escolares compreendem e atuam frente à diversidade, às diferentes concepções, e aos desafios e obstáculos enfrentados nos processos formativos dos alunos. Nesse sentido, a formação de professores para o AEE constitui-se em uma necessidade e em um direito de todos por uma educação mais democrática e inclusiva. 


\section{Referências}

BRASIL. Decreto n.o 7.611. Dispõe sobre a educação especial, o atendimento educacional especializado e dá outras providências. Brasília. 17 nov. 2011.

BRASIL. Coordenadoria Nacional para Integração de Pessoas Portadoras de Deficiências. Declaração de Salamanca e Linhas de Ação sobre Necessidades Educacionais Especiais. Brasília: MEC, 1994.

BUENO, J. G. S. A educação especial nas universidades brasileiras. Brasilia: MEC/ SEESP, 2002.

CARR, W. e KEMMIS, S.. Teoria crítica de la ensenãnza: la investigación-acción en la formación del profesorado. Barcelona: Martínez Roca, 1988.

CHARLOT, B.. Da Relação com o saber: Elementos para uma teoria. Porto Alegre: ArtMed, 2000.

FIORENTINI, D. et.all. Saberes docentes: um desafio para acadêmicos e práticos. In: GERALDI, C. M. G. et. all. (Org.). Cartografias do Trabalho Docente. Campinas/ SP: Mercado das Letras, 2001, p-. 307-335.

GAUTHIER, C.. Por uma teoria da Pedagogia - Pesquisas contemporâneas sobre o saber docente. Ijuí/RS: Ed. Unijuí, 1998.

GIROUX, H. A. Os professores como intelectuais: rumo a uma pedagogia crítica da aprendizagem. Porto Alegre: Artmed, 1997.

JOSSO, M.-C.. Experiências de vida e formação. Trad. José Claudino e Júlia Ferreira. São Paulo: Cortez, 2004.

KASSAR, M. C. M. Práticas pedagógicas e o acesso ao conhecimento: análises iniciais. In: MANZINI, E. J. Inclusão e acessibilidade. Marília: ABPEE, 2006.

NÓVOA, A. (Org.). Profissão professor. Porto: Porto Editora, 1995.

PADILHA, A. M. L. Práticas pedagógicas na educação especial: a capacidade de significar o mundo e a inserção cultural do deficiente mental. Campinas: Autores Associados, 2001.

PEREIRA, J. E. D.. Formação de Professores: pesquisa, representação e poder. Belo Horizonte: Autêntica, 2000.

PIMENTA, S. G. (Org.). Saberes Pedagógicos e Atividade docente. São Paulo: Cortez, 2000.

ROLDÃO, M. do C.. Saber educativo e culturas profissionais - contributos para uma construção/desconstrução epistemológica. Congresso da Sociedade Portuguesa de Ciências da Educação, 8, 2005, Portugal, VIII Congresso da Sociedade Portuguesa de Ciências da Educação. Portugal, 2005, p. 1-26. Disponível em: <www.space.org. pt>. Acesso em: 22 nov. 05.

TARDIF, M.. Saberes profissionais dos professores e conhecimentos universitários. Revista Brasileira de Educação. ANPED, no 13, 2000, p. 5-23.

. Saberes docentes e formação profissional. Petrópolis, RJ: Vozes, 2002. 


\section{CAPÍTULO II \\ EDUCAÇÃO A DISTÂNCIA NA LÓGICA DA \\ MUNDIALIZAÇÃO DO CAPITAL: LIMITES E \\ POSSIBILIDADES PARA A QUALIFICAÇÃO \\ PROFISSIONAL EM SERVIÇO}

Cinval Filho dos Reis ${ }^{1}$

Jane Maria dos Santos Reis ${ }^{2}$

O presente artigo apresenta algumas reflexões acerca da Educação a Distância no Brasil ${ }^{3}$, sobretudo a partir da década de 1990, a partir da qual essa modalidade de ensino pôde contar com recursos avançados proporcionados pelo desenvolvimento da microeletrônica, por sua vez, diretamente articulada às tecnológicas de informação e comunicação. Consequentemente, delimitadas pelo sistema sócio econômico vigente, inúmeras foram e continuam sendo as transformações em várias instâncias da vida social, sobretudo na educacional.

A EaD confrontou com o modelo tradicional presencial, suscitando grandes entraves e debates que movimentam, atualmente, profundas discussões de âmbito acadêmico, em torno da questão da maior eficiência de uma ou de outra modalidade de ensino e aprendizagem. Outra questão que gera grandes polêmicas é sobre o pretenso potencial democratizante que vários autores e órgãos institucionais querem delegar à EaD, como sendo capaz de reduzir a defasagem na formação educacional da nação brasileira - principalmente daqueles que já se encontram em exercício profissional e necessitam de formação específica para a execução de sua função.

Dessa maneira, a EaD é fruto de um desenvolvimento histórico e, como tal, deve ser analisada face ao atual processo de expansão global da educação, em seus diversos níveis e modalidades de ensino. Para isso, é necessário atentar para sua interface com os desdobramentos das relações

\footnotetext{
${ }^{1}$ Cientista Social, Mestre em Educação - Professor Pesquisador II do CEPAE no Curso de Atendimento Educacional Especializado para Alunos Surdos. E-mail: cinvalfilho@hotmail.com

${ }^{2}$ Cientista Social, Mestre em Educação, Doutoranda em Educação - Professora Pesquisadora II do CEPAE no Curso de Atendimento Educacional Especializado para Alunos Surdos. E-mail: jane05@uol.com.br

${ }^{3} 0$ termo Educação a Distância é mencionado, neste artigo, utilizando-se a sigla EaD.
} 
produtivas que passam a emergir a partir da década de 1990, uma vez que são fatores determinantes do processo educacional em debate.

A partir de então, foram criados vários mecanismos legais por parte do governo brasileiro, para garantir a expansão da EaD. 0 principal deles é a LDB ${ }^{4}$ n.o 9.394/96 (hoje, após 15 anos de vigência, demandando reflexões e ajustes contínuos) que em seus Artigos 80 e 87 dispõe sobre a aplicabilidade da EaD em todos os níveis da estrutura e funcionamento do ensino no país. Para Santos (2008), está imerso na LDB um movimento de diversificação e de diferenciação da educação no país, vinculado, em grande medida, às orientações dos organismos multilaterais. Esses organismos enfatizam a flexibilização dos processos formativos, para atender em massa a demanda de adaptabilidade dos processos produtivos delineados pela articulação global da expansão e mundialização do grande capital e que, por consequência, atende a diferentes interesses públicos e privados.

Dessa maneira, objetiva-se problematizar, a partir dos estudos aqui desenvolvidos, as reais possibilidades de democratização da educação via EaD, tão defendida por vários órgãos governamentais, dentre eles, o MEC 5 . Mais especificamente, pretende-se contextualizar a origem da EaD como uma metodologia de ensino, indagando o porquê desta vir adquirindo tamanha expansão em curto espaço de tempo, em contraposição ao modelo de ensino presencial tradicional - com ênfase no processo de mundialização do capital.

Além disso, objetiva-se refletir sobre alguns limites e possibilidades da EaD no contexto da atual sociedade globalizada, delineada pelo interesse dos grandes capitais internacionais.

0 estudo aqui proposto foi concretizado por meio de análises de referências que tratam da questão da $\mathrm{EaD}$ no contexto mundialização do capital e das experiências vivenciadas no trabalho executado pelos autores $^{6}$ da presente pesquisa no Centro de Ensino, Pesquisa, Extensão e Atendimento em Educação Especial da Faculdade de Educação da Universidade Federal de Uberlândia - CEPAE/FACED/UFU) em seus respectivos cursos e edições via EaD. Além disso, as reflexões aqui desenvolvidas são frutos do Grupo de Estudo e Pesquisa em Políticas Públicas e Práticas em Educação Especial - GEPEPES, formado pela equipe de professores pesquisadores, alunos de Iniciação Científica, organizado

\footnotetext{
${ }^{4}$ Lei de Diretrizes e Bases da Educação Nacional.

${ }^{5}$ Ministério da Educação e Cultura.

${ }^{6}$ Os autores da pesquisa fazem parte do CEPAE como Professores Pesquisadores Nível II, no Curso de Atendimento Educacional Especializado para Alunos Surdos.
} 
desde 2009. Foram utilizados na pesquisa bibliográfica, desde autores clássicos, que nos auxiliaram no entendimento e posicionamento crítico da temática aqui abordada, bem como atuais trabalhos científicos de diferentes naturezas, que nos auxiliaram no aprofundamento do debate acerca da EaD no Brasil.

\section{Contextualização da EaD com as mudanças socioeconômicas mundiais}

Hoje se vive um momento no qual a educação vem sendo debatida em várias instâncias da vida social. Um dos principais pontos discutidos vem sendo a eficácia dos modelos tradicionais de educação, enquanto capazes de qualificar um cidadão com uma formação, que possa inseri-lo na sociedade e no mercado do trabalho. Tais interrogações emergem diante de uma sociedade que chega a uma modernidade (que para muitos já é designada de pós-modernidade) calcada no que vários estudiosos preconizam como Sociedade Globalizada. Um processo histórico capitalista que se desenvolve mais fortemente a partir da Revolução Industrial, a partir da qual se iniciou uma profunda revolução tecnológica.

0 processo de globalização acirrou-se face às crises cíclicas do capital mundial, sobretudo, a partir da década de 1970 com a crise instaurada pelo modelo de produção fordista. Diante dessa questão, foi desencadeado na economia mundial processos de transformações tecnológicas e financeiras com novas formas de organização de produção e de trabalho. Com isso, segundo Reis (2009), novas estratégias de mercados deram início a um movimento de reestruturação produtiva nos países capitalistas avançados, levando-os a buscarem novas formas de competitividade e concorrências entre mercados.

A globalização sob a ótica das mudanças socioeconômicas mundiais se desdobra no processo dessa maneira, no fenômeno o qual Chesnais (1996) designa de "mundialização do capital", cujo uso das tecnologias da informação e da comunicação foram claramente delimitados pelo contexto político e econômico vigente.

Assim, contextualmente marcada pelo processo de mundialização do capital, emerge no Brasil a expansão do uso das tecnologias informacionais enquanto vias de "democratização" da educação. Ênfase na técnica ou no processo? Trata-se de questões contraditórias, que demandam problematizações e debates acerca das finalidades da acessibilidade e utilização de tais tecnologias. 
Frutos dessa realidade, os anos posteriores à década de 1990 até os dias atuais, no âmbito da educação, foram e continuam sendo marcados pelo significativo crescimento e estabelecimento de cursos de EaD, e propagados entre as mais distintas áreas do conhecimento. Cursos que, em consonância com a lógica globalizante, são caracterizados pela sua curta duração, voltados para as atividades profissionais que já se encontram em serviço. A exemplo, temos os cursos de Atendimento Educacional Especializado - AEE que, com diferentes ênfases na Educação Especial, são voltados para a demanda de professores da rede de escolas públicas que estão em plena atividade profissional. No caso da escola pública, o AEE corresponde a uma ação massiva de qualificação de professores, estrategicamente estabelecida pelo governo, por meio do MEC, voltada para gerar, com custos e mão-de-obra considerados, por críticos do sistema, reduzidos. Tal o processo formativo cada vez mais recorrente face à realidade e às necessidades da educação básica brasileira.

Para Previtalli e Faria (2007, p. 1)

Como tentativa de responder à crise decorrente do padrão de acumulação taylorista fordista, a reestruturação do capital impõe uma nova ordem produtiva, calcada na flexibilidade, multifuncionalidade, participação e melhoria contínua do trabalhador.

Esse processo de globalização, impulsionado pelo grande avanço tecnológico, ocorreu de maneira mais contundente na área das Tecnologias de Informação e Comunicação - TIC, propiciado pelo avanço da microeletrônica, o que provocou profundas mudanças nas formas como os países se interagem, como as pessoas se aproximam e, obviamente, no processo educacional que, atualmente, vem se apropriando cada vez mais desses instrumentos, como estratégia do processo de ensino e de aprendizagem. A tecnologia é parte dessa luta e como tal mostra todas as contradições do desenvolvimento social. Em certa medida, como ressalta Holloway (1992, p. 29), “[...] o desenvolvimento tecnológico, assim como outros aspectos do desenvolvimento social é marcado pela tentativa sempre contraditória do capital de colocar arreios na criatividade humana".

Portanto, a modernização tecnológica provocou mudanças inimagináveis em poucas décadas, alavancado pelo avanço dos processos de industrialização, pelo surgimento do paradigma da globalização e sob a égide da revolução tecnológica que ampara novos modos de produção. Nesse sentido, Araújo e Viana (2009, p. 01) destacam que 
Cria-se uma nova ordem mundial e internacionalizam-se as economias das nações que passam a investir num novo sistema de produção, agora baseado na parceria, na negociação, na aliança entre as empresas, interligando-se pelo manejo cada vez mais fácil e ágil da informação. Transformações radicais movidas pelas novas formas de produzir e socializar o conhecimento influencia não só a economia mundial, mas, sobretudo redimensionam os paradigmas que orientam a cultura, o trabalho e a educação.

Nesse contexto, a sociedade é invadida por essa lógica capitalista mercadológica na qual seus atores são levados a se adaptarem velozmente às exigências trazidas pelo mundo globalizado. Tais exigências se inserem dentro das empresas e, concomitantemente, invadem o cotidiano da vida social das pessoas, provocando mudanças profundas em seu dia a dia, seja na vida familiar, na condição econômica e, principalmente, na esfera do trabalho e da educação.

A revolução tecnológica originou-se e difundiu-se, não por acaso, em um período histórico da reestruturação global do capitalismo - para o qual foi uma ferramenta básica - e, sendo assim, a nova sociedade emergente desse processo de transformação é capitalista e também informacional, embora apresente variação histórica considerável nos diferentes países, conforme sua história, cultura, instituições e relação específica com o capitalismo global e a tecnologia informacional. (Castells, 1999, p. 31)

Os trabalhadores, agentes do mundo do trabalho, que possuem somente a força de trabalho como fonte de sobrevivência, aderem a essa euforia mercadológica, colocando-se em uma inesgotável corrida em busca de um perfil profissional e social, seja através da realização de cursos técnicos, graduações, ou outros tipos de cursos, na maioria das vezes, de curta duração e de qualidades questionáveis no que se refere ao pano de fundo em questão. Conforme afirma Kuenzer (2006, p. 880),

por força das políticas públicas "professadas" na direção da democratização, aumenta a inclusão em todos os pontos da cadeia, mas precarizam-se os processos educativos, que resultam, em mera oportunidade de certificação, os quais não asseguram nem inclusão, nem permanência.

Nesse cenário, a educação é vista como um dos elementos fundamentais aliada ao capitalismo na condução de uma maestria 
racional. Consequentemente, ficam garantidos os elementos ideológicos e cognitivos capazes de sustentar a dinâmica que garante a manutenção do sistema capitalista, por meio de um discurso pró-dominação. Conforme salienta Lucena,

As pessoas buscam uma (de)formação profissional que os inclua o mais rápido possível no mercado de trabalho. [...] Essa é a mentalidade difundida pela lógica do capital; que faz com que o sistema educacional seja formulado de acordo com os interesses do próprio sistema. Nesse sentido a educação é compreendida não como bem social, mas como serviço orientado pelas regras do mercado (Lucena, 2004, p. 197).

A exigência em relação à formação é, desse modo, sinônima de qualificação profissional. Assim, os cidadãos, desde muito cedo, iniciam a sua vida escolar preocupados em se formar, visando à inserção no mercado de trabalho que muda constantemente, tendo em vista que os trabalhadores devem estar aptos a atenderem às constantes mudanças exigidas pelo mercado consumidor cada vez mais heterogêneo, haja vista que é mundial. Conforme afirma Braverman (1981, p. 124),

O modo capitalista de produção está continuamente se expandindo a novas áreas de trabalho, inclusive àquelas recentemente criadas pelo avanço tecnológico e o emprego do capital a novas indústrias. Ao mesmo tempo, a habituação dos trabalhadores ao modo capitalista de produção deve ser renovada a cada geração.

Nesse sentido, presencia-se uma rearticulação nas instituições educacionais, ou melhor, nos órgãos responsáveis pelo seu gerenciamento, no sentido de se adequarem a essas demandas cíclicas. Essa dinâmica se sustenta pela voracidade que o trabalhador busca uma formação exigida. Tudo isso faz com que o individualismo se acirre ao passo que concorrência entre as empresas é transferida para os trabalhadores. Ao mesmo tempo, Santos (2008, p. 19) diz que

Emerge dessa reestruturação um falso sentido de transformação social, que agrega novos discursos, que se apresentam apoiados em uma demanda por qualificação tecnológica e mão-de-obra especializada para justificar processos excludentes como altos índices de desemprego, trabalhos temporários e precarização das condições de trabalho. 
Ou seja, convencido pelo discurso da expansão Inclusão Educacional e da Educação Especial e seu respectivo projeto estabelecimento nas escolas públicas brasileiras, o professor para se adequar aos imperativos desta ordem mundial, parte em uma desenfreada busca por cursos de qualificação profissional que lhes habilite ao trabalho na Educação Especial. Indo ao encontro desse movimento, temos a oferta de um significativo número de vagas destinada à formação de professores, que se tratam dos cursos em Atendimento Educacional Especializado AEE, ofertados na modalidade a distância, uma vez que a precarização do trabalho docente, não permite que esses profissionais da educação tenham tempo para cursar presencialmente as suas atividades.

Por um lado, verifica-se uma contradição: cada vez mais é exigida uma maior qualificação do trabalhador, porém, por outro lado, este já não tem controle sobre sua própria dinâmica de trabalho e de estudos. Para Chesnais (1996), tanto a educação quanto o trabalho e as respectivas diferenciações de ambos, são configurados de acordo com a dinâmica do sistema de produção capitalista, ou seja, de acordo com a lógica do capital, que delineia "mundialmente" tantos os países centrais, quanto os países periféricos que despertam o seu interesse.

Nesse contexto, para Santos (2005, p. 3), “A educação hoje é uma necessidade da empresa e, consequentemente, implica em repensar um novo perfil de trabalhador, que seja submetido a uma formação que esteja em consonância com a nova realidade produtiva e organizacional do trabalho".

Dessa maneira, a educação associada ao contexto socioeconômico, no que se refere à influência mercadológica aponta que

A produção organizada de conhecimento passou por notável expansão nas últimas décadas, ao esmo tempo que assumiu cada vez mais um cunho comercial como provam as incômodas transições de muitos sistemas universitários do mundo capitalista avançado de guardiães do conhecimento e da sabedoria para produtores subordinados de conhecimento a soldo do capital corporativo (Harvey, 1992, p. 151).

É nesse sentido que a EaD vem tomando corpo, pois é uma modalidade de educação fruto das transformações históricas provocadas pelas exigências cíclicas do modelo econômico capitalista.

A necessidade de ajustar o trabalhador ao trabalho em sua forma capitalista de superar a resistência natural intensificada pelo avanço da tecnologia 
mutável e alternante [...] torna-se um aspecto permanente da sociedade capitalista (Braverman, 1981, p. 124).

Logo, o trabalhador já não pode contar unicamente com o modelo de educação presencial tradicional, rígida e que, de certa forma, vem se mostrando inadequada e/ou insuficiente para atender às demandas suscitadas pelo momento histórico atual, conduzido pelo capitalismo globalizado. Resta, portanto, sair em busca de cursos que sejam flexíveis ao seu trabalho, de modo que, concomitantemente à docência, possam ser efetivados os processos formativos voltados para sua qualificação profissional em serviço.

\section{A EaD no contexto brasileiro}

No Brasil, as primeiras experiências em EaD se deram por meio de cursos via correspondência, tendo ainda o rádio e a televisão como meio de apoio. Uma das instituições pioneiras na Educação a Distância no Brasil é o Instituto Universal Brasileiro, fundado na década de 1940, que segundo pesquisas recentes, mostram que este instituto já formou mais de 3 milhões e 600 mil alunos em cursos técnicos ou supletivos (Castela e Granetto, 2008). Ou seja, é perceptível que entre seus limites e possibilidades, a EaD se caracteriza, a partir de sua trajetória histórica, como modalidade de ensino voltada para o atendimento e qualificação profissional em massa nas mais diferentes áreas.

Na década de 1970, aproveitando-se da ideia de que a TV era uma importante ferramenta para disseminar o conhecimento, foi criado pela fundação Roberto Marinho juntamente com a Fundação das Indústrias de São Paulo, o Telecurso. Esse curso consistia em um método de ensino supletivo, de $1^{\text {o }}$ e $2^{\circ}$ graus, e que também oferecia ensino profissionalizante. Para seu desenvolvimento e concretização, utiliza-se de um modelo de teleducação com aulas via satélite, complementadas por kits de materiais impressos. Esse modelo demarca a chegada da segunda geração de EaD no país. Segundo seus fundadores, o objetivo maior desse programa seria oferecer oportunidades de crescimento profissional e pessoal aos brasileiros.

Os anos de 1990 foram marcantes por terem sido iniciados com muitas expectativas, tendo em vista que o Brasil vivia um cenário político mais democrático, respaldado numa maior participação da sociedade civil que estava organizada no sentido de definir e implementar as políticas sociais. No campo educacional, precisamente em março de 1990, foi 
realizada a Conferência Mundial sobre Educação para Todos, na qual o Brasil era um dos países signatários.

0 projeto educação para todos, elaborado na Conferência em A educação para todos tem como objetivo principal a satisfação das necessidades básicas de aprendizagem, que compreende dois aspectos fundamentais: os instrumentos essenciais para aprendizagem, como leitura e escrita, expressão oral, cálculo e solução de problemas e os conteúdos básicos de aprendizagem, conhecimento e habilidade3s, valores e atitudes (Brasil, MEC, 1993, p. 73).

Essa conferência foi realizada em Jomtien, na Tailândia, onde foram reunidos 155 países - sob orientação e coordenação de organismos multilaterais como o Banco Mundial - os quais assumiram um compromisso de centrar esforços na concepção e no nível de educação definidos pela conferência como prioridade para as décadas seguintes.

Em 1993, os Ministros da Educação dos nove países mais populosos do mundo, inclusive o Brasil, em Nova Delhi, na Índia, assinaram uma declaração, reiterando o compromisso assumido em Jomtien. Os Ministros de Estado ali presentes afirmaram que tinham consciência de que os países, por eles representados, abrigavam mais da metade da população mundial, sendo, portanto, de crucial importância o sucesso dos esforços desencadeados nesses países para alcançar a meta global de Educação para Todos (Santos, 2008, p. 60).

O Brasil implementou várias ações com o intuito de atender as diretrizes da conferência. Santos (2008) destaca o Plano Decenal de Educação que apresentou os dados educacionais brasileiros na época, demonstrando que cerca de 3,5 milhões de crianças na faixa etária de 7 a 14 anos, permaneciam sem oportunidade de acesso ao ensino fundamental.

Nesse cenário a Educação a distância se configura como uma estratégia para ampliação dos meios de alcance da educação básica, através dos meios de informação, comunicação e ação social, em apoio às redes escolares locais, incluindo, entre outros, programas de educação aberta e a distância [...] ao definir as medidas e instrumentos de implementação das ações para universalização da educação básica, o Sistema Nacional de Educação a Distancia, que se encontrava em fase de estruturação, é apontado como forma de aprimorar e ampliar o programa de capacitação e atualização dos professores (Santos, 2008, p. 66). 
Ainda em 1990, a EaD apontava para novos rumos no cenário brasileiro, sendo desenvolvida como uma modalidade educativa também no ensino superior. Como tentativa de institucionalizar tal modalidade no ensino superior foi encaminhado ao Congresso Nacional alguns projetos cujas tramitações, apesar de não terem sido aprovadas corroboraram para a criação do Sistema Nacional de Educação a Distância, em 1993, e para a institucionalização da Universidade Aberta do Brasil (UAB), em 2005.

A partir daí foram criados instrumentos pela Secretaria de Educação Superior, tais como grupos de trabalho, no sentido de sugerirem políticas para Educação Continuada e a Distância no Brasil, inclusive no âmbito da Educação Superior (Brasil, MEC, 1994). Tais grupos tinham ainda a função de elaborar uma proposta do consórcio interuniversitário de Educação Continuada e a Distância - Brasilead, criado por meio do Protocolo de Cooperação n.ำ 3/93, celebrado entre MEC, Ministério das Comunicações, Conselho de Reitores - Crub, Conselho de Secretários de Educação - Consed, e União Nacional dos Dirigentes Municipais de Educação - Undime.

Santos (2008) chama atenção para um dos muitos pontos convergentes que podem ser observados nos documentos que norteiam as diretrizes das políticas nacionais e os que configuram a política mundial, qual seja a lógica da cooperação e da internacionalização, tão recomendada pelos organismos internacionais, especialmente nas últimas décadas. Isso fica claro no Inciso IX do regimento do consórcio Brasilead, quando estabelece que tal consórcio,

Deve buscar a mais ampla cooperação com as universidades estrangeiras, consórcios de educação a distancia e organismos internacionais, privilegiando a colaboração com universidade, centros de educação tecnológica e organizações da região latino americanas (BRASIL, MEC, 1993, p. 3 apud Santos, 2008).

Um dos instrumentos primordiais para a expansão da EaD no ensino de nível superior no campo da legislação foi a Lei de Diretrizes e Bases LDB, Lei $n$. . 9394, de 1996. Nesse documento, foi expressa pela primeira vez, em uma lei dessa natureza, a questão da Educação a Distância, instituindo o seu uso em todos os níveis e modalidades de ensino no país.

Tal prescrição legal, articulada ao processo de reforma da educação superior por meio da adoção do ideário da flexibilização, diversificação e diferenciação institucional, sinaliza que a EaD, enquanto política e 
estratégia na expansão da educação, especialmente da educação superior, estava sendo gestada no âmbito das políticas educativas, como uma modalidade a ser inexoravelmente implementada (Santos, 2008, p. 64).

A partir da década de 1990, através da análise de alguns fatos e medidas institucionalizadas pelo governo brasileiro, de órgãos competentes como o MEC e outros, fica claro o teor neoliberal do conteúdo existente nas legislações criadas na área da educação. Tais documentos foram fortemente influenciados por organismos multilaterais mundiais, tais como OCDE - Organização para Coordenação do Desenvolvimento Econômico, OMC - Organização Mundial do Comércio, BM - Banco Mundial, e FMI - Fundo Monetário Internacional, que funcionam como meios para expansão e dominação dos países centrais capitalistas sobre os países periféricos.

Se até meados anteriores à década de 1990, os cursos na modalidade a distância no Brasil eram propagados por meio das correspondências e da televisão, desse momento em diante, com a intensa expansão da internet, ícone principal das novas tecnologias da informação, foi se configurando em solos brasileiros, a política nacional de Educação a Distância, que a partir das orientações dos organismos internacionais para a educação de países periféricos, como o em questão, trouxe em seu bojo novas formas e conteúdos a diferentes cursos, dentre eles o de qualificação profissional para professores da rede pública. 0 marco destas mudanças está expresso pela LDB de 1996 (Brasil, 1996), especificamente em seu Artigo 80, que trata do respaldo estatal no que concerne aos programas de Ensino a Distância.

A ênfase neste contexto é a reconfiguração do Estado, na qual o sistema capitalista se configura pela orientação desses organismos internacionais do capital. Por um lado, se instala nessa perspectiva, o Estado mínimo, que vem se distanciando de seu papel de proventor das necessidades e bens sociais de sua nação. Por outro lado, com essa "ausência" do Estado, juntamente com o discurso da mundialização do capital (quebra de fronteiras e "homogeneização" da sociedade), as inovações tecnológicas servem de justificava enquanto vias de uma pseudodemocratização da educação. Com a predominância do livre mercado, os acordos firmados pelos organismos internacionais correspondem, juntamente com a mundialização do capital, à sustentação e ao firmamento do capital financeiro e internacional.

Revela-se, então, o foco na técnica e/ou no "progresso técnico" como uma possibilidade de superar os dilemas e as contradições na educação. 
Consequências desse processo são os cursos de formação continuada para o Atendimento Educacional Especializado - AEE, que via EaD, promovem processos formativos dos professores da educação básica brasileira. Por conseguinte, essas demandas se desaguaram nas universidades públicas brasileiras, responsabilizadas pela operacionalização desses cursos. Com isso, os profissionais envolvidos em projetos de elaboração, montagem e manutenção de cursos voltados para o aperfeiçoamento de professores, se esbarram nas contradições do sistema: de um lado, tem-se o debate teórico e crítico, primando pela qualidade do curso e, de outro, tem-se a realidade precária da infraestrutura na qual se sustentam os referidos projetos: tanto a equipe dos cursos quanto os professores que buscam qualificação não usufruem dos elementos básicos para a efetivação dessa proposta Isto é, não conseguem ligar o computador e, consequentemente, acessar a internet, enfim, não possuem conhecimentos sobre tecnologias informacionais.

0 processo de expansão da educação superior no Brasil, nessa ótica, "[...] sob a égide da diversificação e diferenciação das instituições superiores, se coloca como dinâmica crucial e base legal para ampliação das oportunidades educacionais" (Santos, 2008, p. 15). Esse discurso ganha força no processo de reforma do Estado e do sistema educativo no Brasil, de modo que a EaD passa a ser uma modalidade educativa amplamente recomendada pelos organismos multilaterais, e que, a partir da década de 1990, encontrou campo fértil de desenvolvimento no Estado brasileiro.

Nessa perspectiva, para Oliveira (2004, p. 1129),

As reformas da década de 1990 tiveram como principal eixo a educação para a equidade social [...] Passa a ser imperativo dos sistemas escolares formar os indivíduos para a empregabilidade, já que a educação geral é tomada como requisito indispensável ao emprego formal e regulamentado, ao mesmo tempo em que deveria desempenhar papel preponderante na condução de políticas sociais de cunho compensatório, que visem a contenção da pobreza.

Na visão de Santos (2008) deve se cuidar para não perder de vista a educação como processo ideológico de reestruturação do mundo do trabalho, reestruturação esta que vê e educação como instrumento fundamental para a manutenção e revigoramento do sistema capitalista. Outro marco, datado em 2001, corresponde ao Plano Nacional de Educação, que trouxe em seu texto a associação da Educação a Distância à oferta de ensino fundamental e médio, para as camadas mais pobres da população (jovens e adultos "insuficientemente" escolarizados). 
De acordo com Frigotto (1999, p. 20),

A compreensão do cenário em que esse o movimento de expansão da educação, se desencadeia se justifica, pois analisar as articulações e ações desencadeadas para a expansão global da educação, sobretudo da educação superior, requer o entendimento do cenário político, econômico e social em que esse processo se desenvolve, uma vez que sua lógica compõe uma totalidade e como tal, não deve ser pensada isoladamente, e sim como expressão de projetos que em disputa articulam determinados interesses e desarticulam outros, mediante suas ações no campo da construção da realidade, dos valores e atitudes.

Alguns autores, como Guimarães (2008) defende que essas mudanças no campo da Educação a Distância suscitam diversas vantagens. Uma das principais, diz respeito à flexibilidade de horário, que permite que o aluno flexibilize seu tempo de estudo, de acordo com o que mais lhe convier, podendo adequar o processo de estudos ao seu horário e não vice-versa.

Outra questão vista como positiva refere-se a uma maior autonomia no estudo, que faz com que o aluno possa se dedicar mais tempo aos assuntos que mais lhe interessam, sendo o principal responsável pela sua evolução no aprendizado.

Não menos importante surge à questão do espaço, ao ponto que permite que alunos que se encontram distantes fisicamente das escolas e universidades tenham acesso aos cursos desejados.

Quanto aos materiais didáticos, possuem características mais modernas, desenvolvidos especificamente para a EaD. Destaca-se o uso intensivo de elementos multimídia, como vídeo, áudio, computação gráfica e outros. Embasada nessas características, Guimarães (2008) confere à EaD um potencial de democratização do acesso à educação e avanço no processo de ensino-aprendizagem.

Entretanto, existem outras correntes de pensamento que defendem que a EaD, em vez e ajudar a democratizar o ensino, atua exatamente de forma contrária. Uma vez que a grande maioria da população não tem acesso às novas tecnologias, qualquer elemento que valorize esses meios, sem disponibilizá-los para todos, estaria contribuindo para o aumento da desigualdade. 


\section{EaD e os sentidos da qualificação profissional em serviço}

A pergunta que tem sido feita é a seguinte: o que há de novo na EaD? Uma vez que se trata de algo tão antigo, no que se situa a novidade? Do ponto de vista aqui desenvolvido, a novidade da EaD se situa nos instrumentos e/ou técnicas utilizadas nessa modalidade de ensino, para se "sustentar" nos dias atuais, mediantes aos imperativos do capital e às demandas de qualificação profissional. Nesse sentido, a EaD na era da mundialização do capital adquiriu destaque ao se aliar com a internet um poderoso elemento da comunicação da sociedade atual.

Neste contexto do capital em que a flexibilização é uma palavra de ordem, tal princípio se adentrou no cotidiano formativo do professor, neste caso, a flexibilidade pode ser utilizada no turno de trabalho, no horário de realização das atividades, e nas condições materiais para realização do curso. No tocante ao tempo para realização do estudo, a flexibilidade não se aplica, pois estes requerem disciplina e tempo para estudos, registros e realização de atividades avaliativas. Logo, a EaD não pode ser vinculada à "não-presença", uma vez que o tempo é necessário para qualquer processo de ensino e de aprendizagem. 0 que necessita ficar claro é que a $\mathrm{EaD}$, como as outras modalidades de ensino, exige a presença virtual, que deixa de ser física.

Além disso, uma vez que é evidente o que a EaD tem de novo, é possível estabelecer um outro questionamento: quais as finalidades que estão em questão? Qual a finalidade da EaD?

A finalidade é justamente pensar na utilização da internet como uma técnica fundamentadora da EaD nos dias atuais. Consequentemente, a configuração dessas técnicas e outras mais estrategicamente utilizadas na modalidade de ensino em destaque estão associadas às inovações tecnológicas que brotam das contradições da sociedade atual - processo este que vem notavelmente intensificar a mundialização do capital.

De um lado, temos as inovações tecnológicas como vias condutoras ao processo de "democratização" do conhecimento e, por outro, contraditoriamente, redes informacionais inacessíveis a muitos trabalhadores da educação, mas significativamente alcançáveis pelas regiões que são estrategicamente viáveis para o capital. Por conseguinte, numa visão superficial da ótica dominante, que prega a "homogeneização do espaço", a "rede social" se descaracteriza pelo fato de se fazer firmemente presente - embora, muitas vezes, de maneira implícita, a continuidade da diferença e da hierarquia de classes sociais.

Revela-se, neste sentido, a tendência ideológica arraigada 
na dimensão educacional, uma vez que questões básicas, ao serem "filtradas" pela lógica do sistema, são discursivamente derivadas da eficiência e da eficácia, enquanto que a essência aparentemente descentralizada se afasta do sentido, da finalidade dessa modalidade de educação.

Sob a égide do discurso globalizante, busca-se o progresso técnico como finalidade. Desse modo, um dos procedimentos se situa nos financiamentos públicos de políticas educacionais para os setores emergenciais: no caso da Educação Especial, projetos de qualificação docente de professores para atuarem nesta área. O uso das novas tecnologias da informação e da comunicação, por meio da Educação a Distância voltada para a qualificação em serviço de professores, é considerado, portanto, uma estratégia essencial para a Educação Especial no país. Trata-se de um processo longo e complexo quando pensado desde os cursos até a efetivação do seu processo formativo no "chão" das escolas públicas por aqueles que foram qualificados.

\section{Considerações finais}

A problematização das questões aqui debatidas possui sua essência na modernização e adequação da educação escolar à nova ordem mundial que, por sua vez, requer dos profissionais da educação a adequação da sua formação profissional à ordem do capital.

0 que ocorre é que com a chegada das tecnologias da informação na educação se reduziu à modalidade de Educação a Distância direcionada, enfaticamente, às classes sociais mais pobres da população brasileira e à qualificação em serviço de professores. Ou seja, uma das evidências está na formação de professores à distância, que conduz à certificação em massa. Tanto que o próprio curso de Atendimento Educacional Especializado para Alunos Surdos, oferecido pelo CEPAE/FACED/UFU, consiste na oferta de aperfeiçoamento profissional com a oferta 1.000 vagas, por edição, para professores de qualquer região do país.

Logo, uma das armadilhas desta formação de professores consiste no distanciamento da agregação de novas possibilidades aos processos pedagógicos e aproximação às estratégias de substituição tecnológica voltada para a certificação profissional.

É perceptível, portanto, que a EaD no Brasil, sob a ótica do sistema capitalista de produção, se apresentou à educação como uma possiblidade de acesso à globalização econômica e à sociedade da informação. Consequentemente, a referida modalidade de ensino se estabeleceu como 
estratégia de ampliação do acesso à educação, com novas dimensões de espaço e de tempo, visando a formação dos professores em exercício e a certificação em larga escala.

Além disso, os professores desempregados são "culpados" pelos ditames neoliberais, por serem individualmente incapazes pela sua não adaptação às demandas do mercado de trabalho informatizado. Ora, em sua essência, vê-se que a raiz do problema não está nas novas tecnologias da informação como causadoras do desemprego, mas na lógica do capital que se faz cada vez mais presente na sociedade atual, com tentativas cada vez mais opressoras contra o trabalho vivo. Entretanto, tal opressão é mascarada pelo discurso inclusivo que, em profundidade, tem como objetivo maior captar a subjetividade dos indivíduos imersos neste contexto. Soma-se a isso a mundialização financeira, que juntamente com as tecnologias atualizadas, trazem consigo a exclusão de um significativo número de trabalhadores.

Paralelamente à "democratização" da educação informatizada, estão os interesses do capital em obter lucratividade com esta modalidade de ensino, a partir dos avanços tecnológicos que lhe permitem avançar ao avistar novos mercados consumidores.

Os professores, nesta dinâmica, são meros possuidores de uma formação flexível e, diante disso, devem ser capazes de utilizar as novas tecnologias da informação - o que carrega consigo o risco de reduzir a educação a mero treinamento.

É necessária cautela com a pseudo-homogeneização do espaço pregada pela "era" da globalização: o ritmo de acumulação do capital é desigual e se desdobra em profunda concentração de produção e consumo com isso, a própria estrutura tecnológica é diferenciada, pois não é a mesma, uma vez que está presente apenas nos espaços que interessam ao capital.

Além disso, há outra indagação: qual é o acesso e o tipo de tecnologia utilizada nos cursos oferecidos a distância? Eis uma das contradições que constituem desdobramentos do próprio sistema capitalista vigente: a EaD é destinada, a partir das políticas educacionais, àqueles economicamente desfavorecidos, visando a "eficácia' de levar a esses indivíduos, o acesso aos processos educativos. Entretanto, quais as condições reais, em termos tecnológicos e estruturais, que os mesmos possuem de concretizar e finalizar seus cursos?

Os professores em serviço, desse modo, são impulsionados, pela própria lógica do sistema, a se "adequarem" às demandas de trabalho, em virtude que o próprio sistema de avaliação de desempenho docente implantando de diversas formas, nas distintas esferas da rede pública 
(municipal, estadual e federal) transforma tais demandas em necessidades de qualificação profissional que requerem o "uso competente da tecnologia". A ênfase dada para que esses cursos de formações ocorram via EaD se justifica pelo fato de que os organismos internacionais, aliados aos imperativos da mundialização do capital, somente liberam financiamento que seja articulado às novas tecnologias da informação.

Neste contexto, mesmo que os referidos cursos que compõem a Rede Nacional de Formação continuada de Professores em Educação Especial sejam financiados pelo Ministério da Educação - MEC, na prática, os professores precisam agregar um mínimo de competência e condições financeiras para realizá-los. Portanto, a EaD precisa ser pensada com cautela sob a égide de não se transformar em mais uma ferramenta de expropriação da força de trabalho dos profissionais da Educação e demais cidadãos. 


\section{Referências}

ANTUNES, R. Adeus ao trabalho? Ensaio sobre as metamorfoses e a centralidade do mundo do trabalho. 2. ed. São Paulo, SP: Cortez; Campinas, SP: Unicamp, 1995.

Adeus ao Trabalho? Ensaio sobre as metamorfoses e a centralidade do mundo do trabalho. 8. ed. Campinas, SP: Cortez Editora, 2002a.

. Os Sentidos do Trabalho: ensaio sobre a afirmação e a negação do trabalho. 6. ed. São Paulo, SP: Boitempo Editorial, 2002b. 258 p.

Neoliberalismo, Trabalho e Sindicatos: Reestruturação Produtiva na Inglaterra e no Brasil. São Paulo: Boitempo Editorial, 1997.129 p.

ARAÚJO, M. J.Z, VIANA, S. M. A. Possibilidades Aportadas Pela Educação a Distancia. Disponível em: http://www.webartigos.com/articles/24518/1/ POSSIBILIDADES-APORTADAS-PELA-EDUCACAO-A-DISTANCIA/pagina1.html. Acesso em: 26 jan.2010.

BRAVERMAN, H. O trabalho e capital monopolista - A degradação do Trabalho no Século XX. 3. ed. Trad. Nathanael C. Caixeiro. Rio de Janeiro: Zahar Editores, 1981.

BRASIL, LDB. Lei de Diretrizes e Bases da Educação Nacional. Lei no 9394 de 20 de dezembro de 1996 - estabelece as diretrizes e bases da educação nacional. Diário Oficial da União. Brasília, DF, 1996

CASTELA, G. da S. GRANETTO, J. C. EAD: Histórico e Implicações nos Processos de Ensino aprendizagem. In: Simpósio Nacional de Educação, 1, 2008, Cascavel: Anais do $1^{\circ}$ Simpósio Nacional de Educação, Cascavel, 2008. v. 1.

CASTELLS, Ml. A sociedade em rede: a era da informação: economia, sociedade e cultura - v.1. São Paulo: Paz e Terra, 1999.

CHESNAIS, F. A Mundialização do Capital. Tradução de Silvana Finzi Foá SP: Xamã, 1996.

FRIGOTTO, G. Educação e a crise do trabalho real. 3.ed. São Paulo: Cortez, 1999.

GUIMARÃES, J. M. de M. Educação, globalização e educação a distância. Rev. Lusófona de Educação, Lisboa: Edições Universitárias Lusófonas, n. 9, p. 139-158. 2007.

HARVEY, D. Condição Pós-Moderna. Uma Pesquisa sobre as Origens da Mudança Cultural. São Paulo: Edições Loyola, 1992.

HOLLOWAY, J. e PELÁEZ, E.. Aprendendo a curvar-se: pós-fordismo e determinismo tecnológico. Revista do Instituto de Estudos Socialistas. São Paulo. n.ํㅡㄹ 2, p. 21-30. Outubro,1998.

KUENZER, A. Z.. A educação profissional nos anos 2000: a dimensão subordinada das políticas de inclusão. Educação e Sociedade. Campinas: Unicamp, v. 27, n. 96 Especial, p. 877-910, out. 2006.

LUCENA, C.. Tempos de destruição: educação, trabalho e indústria do petróleo no Brasil. Campinas: Autores Associados; Uberlândia, MG: EDUFU, 2004. 
MÉSZÁROS, I.. A teoria da alienação em Marx. São Paulo: Boitempo, 2006.

OLIVEIRA, A. Marx e a exclusão. Pelotas: Seiva, 2004.

PREVITALLI, F. S. As Relações de Subcontratação no Setor de Autopeças: um estudo de caso. 1996. Dissertação (Mestrado em Sociologia). IFCH/UNICAMP. Campinas: 1996.

Reestruturação Produtiva e Novas Relações Interfirmas na Cadeia Automobilística nos Anos 90, Revista Produto \& Produção. Porto Alegre/RS. v. 4, n. - 3. Outubro, 2000.

Controle e resistência do trabalho na reestruturação produtiva do capital. Ideias. Campinas: IFCH/Unicamp, v. 2, ano 9 - v. 1, ano 10, 2003.

PREVITALLI, F. S; FARIA, A. F. Reestruturação Produtiva e Controle do Trabalho: o caso do setor de tabaco em Uberlândia/MG. In: Colóquio Internacional Marx Engels, 5, 2007. Campinas: Unicamp, Anais do 5ํo Colóquio Internacional Marx Engels, 2007.

REIS, C. F. dos. O papel da informática no avanço tecnológico: a exigência de um novo perfil para o trabalhador. Horizonte Científico. no‥ 01, Semestral, 2002. Disponível em: www.propp. ufu.br/revistaeletronica/edicao2002/ G/0\%20 PAPEL\%20DA\%20INF.PDF. Acesso em: 22 agos. 2008.

SANTOS, C. A. A expansão da educação superior rumo à expansão do capital: interfaces com a educação a distância no Brasil, São Paulo: USP. 2008.

SANTOS, J. M. dos. 0 trabalho enquanto dimensão contraditória da potencialidade humana na trajetória de reestruturação produtiva. Revista Urutágua. Maringá, no 07, ago./set./out./nov., 2005. Disponível em: http://www.urutagua.uem. br/007/07santos.htm. Acesso em: 20 ago. 2005. 


\title{
CAPÍTULO III \\ ENSINO DA LÍNGUA BRASILEIRA DE SINAIS E FORMAÇÃO DE PROFESSORES A DISTÂNCIA
}

\author{
Marisa Pinheiro Mourão ${ }^{1}$ \\ Arlete Aparecida Bertoldo Miranda ${ }^{2}$
}

0 atual contexto educacional das pessoas surdas demonstra que, após décadas de discursos e práticas educacionais de reabilitação e normalização, nos últimos anos, houve avanços significativos no campo de pesquisas e produção de materiais para a melhoria das condições de inclusão do surdo na sociedade e na escola (Dorziat, 1999; Fernandes, 2003; Quadros 2004; Sá, 2006). É notável o crescimento da consciência desse grupo em busca do reconhecimento da sua identidade, cultura e direitos.

Um importante marco dessas conquistas é a oficialização da Língua Brasileira de Sinais (Libras) por meio da Lei n.o 10.436, de 24 de abril de 2002, que torna a Libras a segunda língua oficial do país. Além disso, a regulamentação do Decreto n. ${ }^{-}$5.626, no final de 2005, determina a inclusão desta língua como disciplina curricular obrigatória nos cursos de formação de professores em nível médio e superior.

Essas conquistas precisam ser traduzidas em ações que permitam aos surdos o acesso a uma educação de qualidade. Logo, são necessárias não só adaptações curriculares, mas também a efetivação de rupturas ideológicas e a mudança da práxis pedagógica, bem como a transformação do currículo básico presente na formação docente. No entanto, apenas ter a consciência da transformação não é suficiente para habilitar os professores e instrumentalizá-los para agir na prática. Para isso, acreditamos serem necessários investimentos na formação acadêmica inicial e continuada desses profissionais, para que eles consigam desempenhar o seu trabalho junto aos aprendizes surdos, munidos de conhecimentos teóricos e práticos, a começar pelo aprendizado da Língua de Sinais. Essas transformações precisam conduzir a uma ação docente que respeite e trabalhe com as diferenças dos surdos com base nas suas especificidades linguísticas, identitárias e socioculturais, determinadas por uma cultura e por uma experiência visogestual e não mediante uma visão físico-biológica (Skliar, 1998).

\footnotetext{
${ }^{1}$ Professora da Faculdade de Educação da Universidade Federal de Uberlândia UFU, mestre em Educação.

${ }^{2}$ Professora doutora da Faculdade de Educação e do Programa de Pós-graduação em Educação da Universidade Federal de Uberlândia, orientadora do trabalho.
} 
Partindo do princípio de que a Libras é a língua materna dos surdos brasileiros, entendemos que há uma necessidade urgente de torná-la acessível aos profissionais da educação que atuam com pessoas surdas, salientando que a comunicação é uma condição básica para qualquer processo de ensino e aprendizagem. Consideramos, então, que o movimento de divulgação e ensino dessa língua poderá contribuir com a comunidade surda na garantia de uma participação mais efetiva na sociedade e o acesso a uma educação de qualidade a todos os seus membros.

Nesse contexto, é que este trabalho começa a se estruturar. Procuramos nos aliar à realidade atual pautada na busca de apoio ao trabalho educacional e de ações alternativas de formação docente, em que as Tecnologias da Informação e da Comunicação - TIC podem se tornar uma ferramenta alternativa e diversificada para atender às demandas da realidade educacional de um país de dimensões continentais como o Brasil. Moran (2007) destaca que uma parte significativa dessa formação está relacionada ao uso da Educação a Distância - EaD, como forma de atingir novos públicos e desenvolver novas estratégias de ensino.

As tecnologias relacionadas à inclusão de pessoas surdas estão presentes em muitas iniciativas que vêm sendo desenvolvidas por vários autores e órgãos federais, para difundir a Libras no Brasil, tais como: Capovilla \& Raphael (2001); Dicionário Digital de Libras MEC/SEESP (2002); Misseno \& Carvalho (2003); Lira (2003); Coradine (2002); Costa (2002). Essas iniciativas têm repercutido positivamente na educação dos surdos brasileiros.

Sendo assim, em 2006, uma empresa ${ }^{3}$ da cidade de UberlândiaMG deu início ao desenvolvimento do "Librasnet: curso para o ensino da Língua Brasileira de Sinais via web" ${ }^{\prime \prime}$. Este curso seria o primeiro na modalidade a distância, mediado pela internet, para ensinar a Libras de forma contextualizada, utilizando a linguagem HTML (HyperText Markup Language) e recursos de animação em duas dimensões.

Posteriormente, esse curso foi inserido no projeto "Professor e Surdez: cruzando caminhos, produzindo novos olhares" ${ }^{5}$, elaborado

\footnotetext{
${ }^{3}$ Este curso foi desenvolvido pela empresa Araújo e Araújo Ltda que utiliza o nome fantasia Meg@info. Esta é uma empresa de base tecnológica, localizada em Uberlândia - MG. Home-Page: www.megainfo.inf.br

${ }^{4}$ A autora do presente artigo participou durante toda a elaboração do curso Librasnet como Pedagoga e roteirista das Lições do Curso.

${ }^{5}$ Este projeto foi elaborado pela autora deste trabalho juntamente com a Prof. ${ }^{\text {a }} \mathrm{Dr}^{\underline{a}}$ Lázara Cristina da Silva, da Faculdade de Educação da UFU.
} 
pela Universidade Federal de Uberlândia - UFU, por meio do Centro de Ensino, Pesquisa, Extensão e Atendimento em Educação Especial CEPAE, e aprovado pelo Ministério da Educação - MEC e Secretaria de Educação Especial - SEESP, no segundo semestre de 2007, para compor a Rede de Formação Continuada de Professores em Educação Especial, na modalidade a distância. A proposta consistia na oferta de um curso a distância, mediado pela internet, para a formação de 500 professores da rede pública, de vinte cidades do Brasil, em caráter de extensão. Como parte prática, o projeto utilizaria o Librasnet para o apresentação da Libras, pois este já se encontrava totalmente concluído pela empresa supracitada, parceira da UFU desde 2006.

Surgiu então, a questão que norteou este estudo: 0 curso Librasnet poderia contribuir como uma ferramenta para a formação continuada de professores a distância destinados à educação de pessoas surdas?

Dessa maneira, demarcamos como objetivo principal da pesquisa investigar e analisar as contribuições do curso Librasnet, realizado na modalidade a distância, por meio da internet, como ferramenta para a formação continuada de professores da rede pública de ensino de dezessete municípios do Brasil, que atuavam ou desejavam atuar com a educação de pessoas surdas. Apresentaram-se como objetivos específicos:

Realizar um levantamento do perfil dos participantes.

Identificar as principais dificuldades e/ou facilidades encontradas pelos alunos na realização do curso Librasnet.

Verificar a utilização das ferramentas de comunicação como: fórum, bate-papo, correio eletrônico, mural e enquete.

Mapear a avaliação final dos participantes em relação ao curso.

De uma maneira geral, pretendemos com este estudo contribuir com a formação de professores que atuam ou desejam atuar com aprendizes surdos, por meio da difusão da Libras e do oferecimento de um espaço para reflexão e discussão, junto aos profissionais da educação de várias regiões do país. Cabe ressaltar que este estudo não tem a finalidade de substituir a aquisição do uso social da Libras por meio do contato com a comunidade surda, mas sim, oferecer um espaço alternativo para a formação continuada de professores.

\section{Descortinando os horizontes sobre a Educação dos Surdos}

Atualmente, as políticas públicas brasileiras apresentam grandes avanços no que diz respeito à compreensão das diferenças implicadas na educação de pessoas surdas. Diferentemente da maior parte da história da 
educação desse grupo de pessoas, no qual a abordagem clínico-terapêutica (SKLIAR, 1998), de caráter medicalizador, buscava "normalizá-las" como única forma capaz de integrá-las à sociedade, hoje, este grupo de pessoas luta pelo respeito à sua identidade e cultura, buscando a sua independência social, econômica e pessoal.

Atualmente, no Brasil, podemos perceber as conquistas das pessoas surdas pautadas na proposta educativa bilíngue. Quadros (2004) defende que o "Bilinguismo" é uma proposta de ensino que considera a Língua de Sinais como língua natural da criança surda, ou seja, como sua primeira língua, que deve ser aprendida o mais cedo possível, e a Língua Portuguesa escrita, como língua de acesso ao conhecimento, que deve ser ensinada a partir da Língua de Sinais.

Tal abordagem depende da presença de professores bilíngues que tenham domínio das duas línguas envolvidas, utilizando cada uma em diferentes momentos. A utilização da proposta bilíngue não é apenas a tradução de uma língua para outra, pois a Língua Portuguesa e a Língua de Sinais têm bases originárias distintas, princípios e regras gramaticais diferenciadas: a Libras tem uma modalidade viso-gestual, e a Língua Portuguesa, oral-auditiva. Além disso, ao abrir espaço para a Língua de Sinais como primeira língua de instrução, é preciso entender que os surdos têm uma cultura própria, que deve ser reconhecida e respeitada.

É preciso ressaltar que as pessoas surdas ${ }^{6}$ têm a Língua de Sinais como língua natural de comunicação, e é por meio dessa que a maioria dos surdos tece as suas relações com o mundo. Assim, o desenvolvimento de uma Língua de Sinais, cuja aquisição se processa de maneira natural para o sujeito surdo, será a base para a aquisição de uma segunda língua, pois esta lhe dará as condições necessárias para o desenvolvimento de sua cognição, de sua autoestima e de sua identidade.

A Língua de Sinais, utilizada pela comunidade surda brasileira, foi reconhecida oficialmente pela Lei Federal n.o 10.436, de 24 de abril de 2002, como Língua Brasileira de Sinais (Libras). A referida lei, em seu Art. 1o, parágrafo único, define a Libras como

A forma de comunicação e expressão, em que o sistema linguístico de natureza visual-motora, com estrutura gramatical própria, constitui um sistema linguístico de transmissão de ideias e fatos, oriundos de comunidades de pessoas surdas do Brasil.

\footnotetext{
${ }^{6}$ Segundo dados do Instituto Brasileiro de Geografia e Estatística (Censo IBGE, 2000), existem, no Brasil, cerca de 5,7 milhões de pessoas com algum grau de perda auditiva.
} 
De acordo com Ferreira Brito (1997), a Libras é dotada de uma gramática organizada a partir de elementos constitutivos das palavras e de um léxico (o conjunto das palavras da língua) que se estruturam com base em mecanismos morfológicos, sintáticos e semânticos. Estes possibilitam a produção de um número infinito de construções por meio de um número finito de regras.

Com relação a sua "Estrutura Sintática”, Strobel e Fernandes (1998, p. 15) esclarecem que a Libras não pode ser estudada tendo como base a Língua Portuguesa, porque esta tem uma gramática diferenciada, independente da língua oral, que também é composta pelos níveis linguísticos: fonológico, morfológico, sintático e semântico. A ordem dos sinais na construção de um enunciado obedece a regras próprias, que refletem a forma de o surdo processar suas ideias, com base em sua percepção visual-espacial da realidade

Libras: IDADE VOCÊ (expressão facial de interrogação)

Português: "Quantos anos você tem?"

Libras: FLOR EU-DAR MULHER^BENÇÃO (verbo direcional)

Português: "Eu dei a flor para a mamãe."

Os dados publicados pelo MEC e SEESP (2006), referentes à "Evolução da educação especial no Brasil", revelam que entre os anos de 2003 a 2005, o número de alunos surdos matriculados na educação básica e em instituições de ensino superior vem crescendo a cada ano no Brasil. No entanto, os dados apontam uma substancial diferença entre o número de alunos surdos presentes na educação básica em contraste com o número de alunos que conseguem ingressar no ensino superior.

A inclusão de alunos surdos nas escolas regulares tem ressoado em uma série de desafios socioeducacionais, dentre os quais podemos destacar a adaptação do espaço físico da escola, das metodologias de ensino e da formação inicial e continuada dos professores, ressaltando que não basta apenas que estes aprendam a Libras, mas que aprendam, em seus cursos de formação, como desenvolver uma prática de ensino e aprendizagem que considere as necessidades de aprendizes surdos.

Na visão de Sá (2006), quando se opta por utilizar a Libras como primeira língua no processo educativo dos surdos, necessita-se entender que tal postura altera toda a organização escolar: os objetivos pedagógicos, as práticas de ensino e aprendizagem e a participação da comunidade surda no processo escolar. 
No que concerne à proposta educativa bilíngue, embora reconhecendo-a como a que mais respeita as diferenças das pessoas surdas, ainda há uma série de questões de cunho político-pedagógico que merecem reflexão e necessitam de uma reestruturação dentro das escolas onde os surdos estão incluídos.

Entendemos que o professor, ao desenvolver suas atividades curriculares voltadas para o ensino do aluno surdo, precisa realizá-las utilizando a Libras, pois, segundo a Lei n.․ㅜ 10.436/2002 e o Decreto n.․ㅡ $5626 / 2005$, esses alunos têm o direito de se comunicarem, aprenderem e serem avaliados na sua primeira língua - a Libras. Neste caso, acreditamos na necessidade de se ter professores bilíngues atuantes na escolarização desses alunos. Nessa perspectiva, não há preocupação em negar as diferenças, mas fazer com que o surdo assuma o seu papel como cidadão brasileiro, em condições de participar ativamente da sociedade, considerando as suas peculiaridades na inclusão social e práxis escolar.

Neste sentindo, é essencial a transformação do currículo e da formação docente, contribuindo para que o espaço escolar seja capaz de propiciar um ambiente de construção do conhecimento que respeite as diferenças linguísticas, identitárias e especificidades culturais das pessoas surdas. A inclusão que aqui se almeja é aquela que compreende o acesso igualitário ao conteúdo curricular, garantindo aos surdos, não somente o acesso à educação, mas a sua permanência escolar e progressão nos estudos.

\section{Elos entre as tecnologias da informação e comunicação e a divulgação da Libras}

Atualmente, a utilização de cursos na modalidade a distância tem repercutido na formação de professores que buscam espaços diversificados de estudo, reflexão e discussões teóricas/metodológicas, aliada ao aumento das exigências do governo brasileiro, nos últimos anos, pela certificação e ampliação da formação profissional, que se depara com a defasagem nas condições de formação docente no país.

Esta modalidade de educação vem alcançando, cada vez mais, uma posição de destaque no Brasil, sendo vista por muitos como um instrumento de democratização do acesso à informação, proporcionando a participação e o acesso de pessoas excluídas dos processos educacionais, por questões de horário, localização de moradia ou falta de recursos materiais entre outras causas (Belloni, 2006; Moran, 2007; Kenski, 2009). 
Não se pode negar, atualmente, que a disseminação da informação, aliada ao uso das mídias educativas, tem colocado recursos como o computador, a internet e o vídeo a serviço da educação. Aliar essas tecnologias ao oferecimento de cursos de formação de professores pode se tornar uma ferramenta alternativa e diversificada para atender as demandas da realidade educacional de um país de dimensões continentais como o Brasil.

É notória a questão da necessidade de formação especializada dos professores para atuar com aprendizes surdos dentro de uma sociedade globalizada, multicultural, tecnológica e em ritmo de atualização constante. Oriundos de uma formação aligeirada e superficial, que não consegue atender às especificidades comuns no cotidiano escolar, os professores que atuam com alunos surdos, na maioria das vezes, buscam cursos de formação pelo seu próprio interesse e/ou aprendem a trabalhar com a diferença desse aluno no próprio contato na sala de aula.

Sendo assim, o desenvolvimento de recursos didáticos, cursos, softwares, ambientes de aprendizagem, entre outros, tem oferecido diversas oportunidades de formação continuada e, até mesmo, para consulta e utilização por parte dos profissionais que atuam com pessoas surdas. Hoje, diversos sites e ambientes disponíveis na internet dispõem de conteúdos, propostas e recursos para auxiliar o professor na práxis escolar. No entanto, apesar da existência desses materiais e/ ou ambientes virtuais, estes, em sua maioria, apresentam o conteúdo de forma descontextualizada, ou encontram-se em fase de conclusão, em decorrência, sobretudo, dos altos cursos de produção e escassez de profissionais qualificados (Coradine, 2002; Costa, 2002; Misseno \& Carvalho, 2003; Lira, 2003).

Em meio a esse contexto, vimos que muitos materiais e estratégias vêm sendo produzidos em prol da difusão da Libras e da inclusão do surdo. Porém, esse cenário ainda revela algumas limitações, além de se restringir, muitas vezes, a materiais impressos, o que dificulta a sua circulação, dada às dimensões geográficas do país. Outro fator limitante é a compreensão da complexidade da Libras, que utiliza movimentos gestuais e espaciais, que dificilmente pode ser esclarecido por meio de materiais impressos.

Pelos motivos supracitados, surgiu a necessidade de desenvolver um curso de Libras a distância para ser utilizado como uma ferramenta complementar de ensino e aprendizagem. Considerando, também, a necessidade de aprendizagem da Libras, por parte dos professores, familiares e demais pessoas que se relacionam com os surdos, desenvolver um curso para a divulgação dessa língua, mediado pela internet, poderia 
disseminar de forma abrangente o uso dessa comunicação e, levá-la até as regiões do país que não tenham uma pessoa habilitada para ensiná-la.

Sendo assim, em 2006, uma empresa da cidade de Uberlândia - MG deu início ao desenvolvimento do "Librasnet: curso para o ensino da Língua Brasileira de Sinais via web". Este, contou com o apoio financiador do Conselho Nacional de Desenvolvimento Científico e Tecnológico - CNPq e o trabalho de uma equipe multidisciplinar, composta por uma professora de Libras, usuária da Libras, seis web designers, dois programadores, uma coordenadora pedagógica ${ }^{7}$, um analista de sistema, e a assessoria pedagógica da Faculdade de Educação - FACED da UFU e, também, com a validação do curso, por meio da parceria com a Associação de Surdos de Uberlândia - Asul.

O curso foi desenvolvido para ser ministrado na modalidade a distância, por meio de uma plataforma de ensino intitulada toLearn ${ }^{8}$. Na sua montagem foi utilizada a linguagem HyperText Markup Language HTML, e recursos de animação em duas dimensões (2D), produzidas com o suporte do software Corel DRAW X e animadas com o programa Adobe ${ }^{\circledR}$ Flash ${ }^{\circledR}$ CS3 Professional 8.

O Librasnet foi desenvolvido com base em metodologia de ensino contextualizada (Felipe \& Monteiro, 2001), iniciando a apresentação do conteúdo pela comunicação básica, assim como a própria identidade das pessoas, suas características físicas, sua história de vida, sua família, entre muitas outras situações de comunicação e relacionamento cotidiano. 0 ambiente de aprendizagem foi elaborado para um público leigo e poderia ser utilizado, também, por pessoas usuárias da língua interessadas em conhecer recursos diversificados.

Nesse propósito, os conteúdos do curso foram escolhidos para serem apresentados nas atividades cotidianas do personagem Eduardo - Dudu, uma criança surda de dez anos de idade, personagem principal da história. Os diálogos acontecem entre os personagens da família do Dudu: sua mãe Ana, seu pai José Carlos - Zeca e sua irmã Marina, todos

\footnotetext{
${ }^{7}$ As principais atividades desenvolvidas por mim no projeto foram: criar as histórias cotidianas na qual se davam o ensino da Libras, transformá-las em storyboard's a serem desenvolvidos pela equipe de designers, apresentar e discutir com a Associação de Surdos de Uberlândia e demais pessoas envolvidas o conteúdo do curso, criar as atividades interativas, jogos, questões de múltipla escolha e dissertativas etc.

${ }^{8}$ Plataforma de gestão de cursos ministrados a distância, com a mediação da internet. Desenvolvida em linguagem de programação Java, utiliza a arquitetura Java2 Platform Enterprise Edition (J2EE), servidor de aplicações Java para web (TomCat) e um sistema de gerenciamento de banco de dados (MySQL).
} 
eles ouvintes, que utilizam a Libras para se comunicarem com o Dudu em diversas situações e ambientes onde a história se passa.

A equipe do projeto elaborou e seguiu um processo de desenvolvimento, em etapas, para a criação das lições do curso. 0 início dessa estruturação começava com a equipe pedagógica, por meio da elaboração do "Storyboard" das lições, seu roteiro, atividades interativas, dicionário, entre outros. Após o desenho das configurações de mãos necessárias para a montagem do sinal, era realizada a sua animação e, posteriormente, a organização de todos os sinais na estrutura da frasal da Libras. Por último, a professora de Libras realizava as correções juntamente com a equipe pedagógica, e a lição era apresentada à Asul, para avaliação e correção.

Durante todo o curso, é constante a utilização de imagens associadas à apresentação de um novo sinal ou contexto, assim como os diálogos entre os personagens. Para isso, o curso considera as diferenças estruturais próprias da Libras, distintas da estrutura da Língua Portuguesa, que se baseia na construção Sujeito-Verbo-Objeto. Na Libras, a frase, geralmente, tem uma sequência frasal topicalizada. Exemplo: Português: "Hoje meu amigo vem visitar a minha casa", Libras: "AMIGO VISITAR CASA MEU HOJE" (Strobel \& Fernandes , 1998; Quadros , 2004).

Figura 1 - Interface do ambiente de aprendizagem

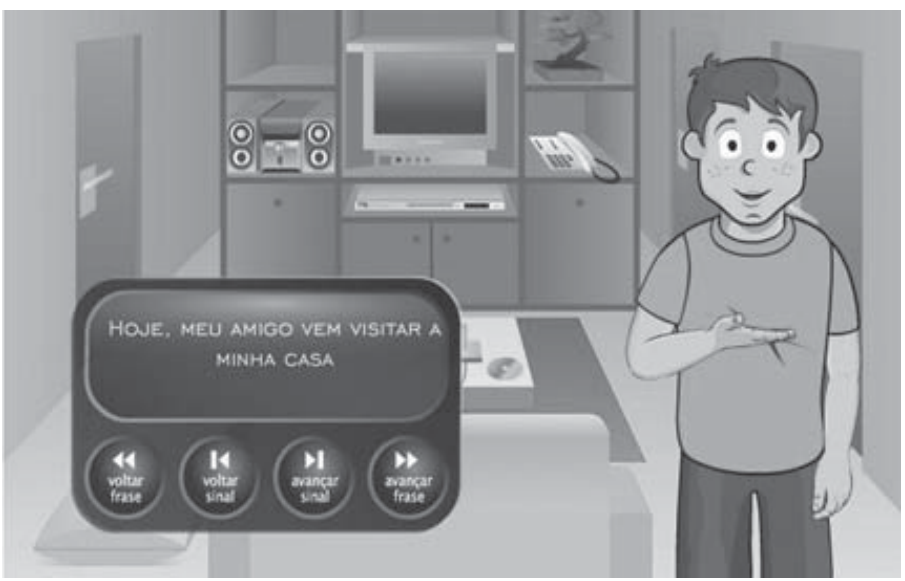

Fonte: Ambiente de aprendizagem do curso Librasnet - Jan. 2009

\footnotetext{
${ }_{9}^{9}$ Storyboard é uma ferramenta para criação de roteiros, contada em quadros. Essa ferramenta se parece com uma história em quadrinhos sem balões. É uma etapa na visualização de algo que será realizado em outro meio. Disponível em: <http:// www.spacca.com.br/educacao/storyboard.htm>. Acesso em: 14 set. 2008.
} 
Os sinais apresentados no curso correspondem a situações vividas e a termos utilizados no dia a dia das pessoas, tais como: verbos; pronomes, adjetivos; sentimentos, expressões faciais, móveis, objetos, eletrodomésticos, roupas, cores, lugares, ambiente escolar, alimentos, corpo humano, higiene, doenças, remédios, cidade, profissões, noções de tempo, números, alfabeto, documentos pessoais, família, entre outros. No entanto, estes não estão agrupados em categorias, mas encontram-se contextualizados em várias situações cotidianas. Sendo assim, o conteúdo programático do curso Librasnet abrange 1.000 sinais distribuídos em nove lições: Apresentação do curso; Lição 1 - Você tem uma identidade; Lição 2 - Você tem uma história; Lição 3 - A família e o trabalho; Lição 4 - Minha casa: A sala e o banheiro; Lição 5 - Minha casa: 0 quarto e as cores; Lição 6 - Minha casa: A cozinha e os alimentos; Lição 7 - A escola: A sala de aula do Dudu; Lição 8 - A Escola: A sala de aula do Dudu - Parte II; Lição 9 - As férias da família.

A plataforma onde o curso é hospedado permite a gestão e o acompanhamento do aluno, e disponibiliza um conjunto de estratégias pedagógicas que facilitam a sua aprendizagem, tais como: o "Dicionário da lição", o "Alfabeto manual", as atividades do "Aprenda brincando", os "Testes de verificação", o "Você sabia?", e os "Sinais parecidos". Além disso, a plataforma conta com as ferramentas básicas de comunicação e interação, tais como: fórum, bate-papo, correio-eletrônico, enquete, anotações, biblioteca, mural, relatórios de atividades, entre outros, que facilitam a troca de informações entre o aluno e o professor/tutor e o suporte durante o curso.

Dessa maneira, descritas as peculiaridades do Ambiente Virtual de Aprendizagem - AVA proposto no curso Librasnet, assim como as suas estratégias pedagógicas, adentra-se em um momento crucial: o oferecimento do curso. Desta maneira, definimos como campo de investigação e coleta de dados o curso "Professor e surdez, cruzando caminhos, produzindo novos olhares", oferecido pela UFU, por meio do CEPAE e da Pró-reitoria de Extensão, Cultura e Assuntos Estudantis Proex, pertencente ao Programa de Formação Continuada de Professores em Educação Especial, na modalidade a distância do MEC e da SEESP, em parceria com a Universidade Aberta do Brasil - UAB.

Tal projeto foi contemplado no segundo semestre de 2007, por meio do Edital n. ${ }^{\circ}$ 11, de 22 de agosto, por meio do qual a SEESP tornou público o resultado da fase II do Edital n. $\frac{0}{6}$ do processo de seleção para o Programa de Formação Continuada de Professores na Educação Especial. 
Foram contemplados para a participação no curso $500^{10}$ professores da rede pública de ensino de 20 municípios do país, em caráter de extensão (120 horas), sendo eles: Araci - BA; Araguari - MG; Congonhas - MG; Derrubadas - RS; Ererê - CE; Ibaté - SP; Ipameri - GO; Itapecerica da Serra - SP; Muriaé - MG; Nova Serrana - MG; Pires do Rio - GO; Rio Grande - RS; Rubiataba - GO; Salete - SC; São Miguel do Araguaia - GO; Sete Lagoas MG; Taió - SC; Tamboril - CE; Três Rios - RJ; Vila Velha - ES.

Como abordagem metodológica, adotamos a pesquisa qualiquantitativa, por se fundamentar em dados fixados nas interações interpessoais, trazendo liberdade ao pesquisador para atuar no contexto investigado. Nas palavras de Romanelli \& Biasoli-Alves (1998, p. 11), "enquanto o quantitativo se ocupa com ordens de grandezas e as suas relações, o qualitativo é um quadro de interpretações para medidas ou a compreensão para o não quantificável".

Todos os profissionais selecionados para atuar no projeto eram professores da rede pública de ensino e atuavam com a Educação Inclusiva. Todos os 20 tutores selecionados tinham especialização, 2 professores formadores eram mestres, 6 tinham especialização em Educação Especial, sendo 3 doutores da área de psicologia e 1 mestre da área de educação. Quatro profissionais eram surdos e atuavam como instrutores de Libras e oito atuavam como intérpretes em escolas de Uberlândia - MG. A capacitação desses profissionais abrangeu o período de setembro a novembro de 2007.

0 tutor a distância era responsável pela orientação e acompanhamento de uma turma de 20 a 25 alunos, observando a sua participação nas atividades propostas. 0 professor formador era responsável pela elaboração de material, e acompanhava as discussões teóricas de duas turmas. 0 tutor presencial atuava como representante pedagógico da Secretaria de Educação do município, exercendo a supervisão e o acompanhamento dos alunos na sede/polo. 0 coordenador de tutoria era responsável pela orientação e acompanhamento de todos os profissionais envolvidos no curso, observando as participações nas atividades realizadas. A coordenação geral do projeto ficou a cargo de uma professora da UFU e coordenadora do CEPAE ${ }^{11}$, que respondeu, acadêmica e administrativamente, pelo projeto.

Por considerar que a educação de surdos ultrapassa a questão da Língua de Sinais, o curso também foi composto por discussões teóricas

10 Das 500 vagas disponibilizadas pelo projeto, foram preenchidas 480 . Consideramos "preenchidas" as vagas cujos alunos efetivaram a matrícula e deram início ao curso.

${ }^{11}$ Prof. ${ }^{\text {a }}$ Dr. ${ }^{\text {a }}$ Lázara Cristina da Silva. 
elaboradas pela equipe de professores formadores e pesquisadores da UFU. As discussões visavam inserir o participante em questões relacionadas à educação de pessoas surdas, bem como fornecer um espaço para reflexão e discussão que melhor atendesse à prática pedagógica e às necessidades de aprendizes surdos. Essas discussões e reflexões giravam em torno de assuntos, tais como: história da educação de pessoas surdas no Brasil, concepções de surdez, filosofias educacionais para alunos surdos, práticas pedagógicas e surdez, cultura e identidade surda, Libras, entre outros. Na segunda parte do curso, foi utilizado o conteúdo do curso Librasnet, que abrangia a apresentação contextualizada de 1.000 sinais da Libras, e também foi realizado o estudo, em nove lições, das suas funções gramaticais.

Visando proporcionar uma apreciação criteriosa dos dados, este estudo se restringiu à análise de uma amostra de $20 \%$ dos alunos participantes do curso, o que correspondeu a 96 professores, oriundos de 17 municípios $^{12}$. 0 critério de seleção baseou-se no sorteio dos alunos/ cursistas que haviam respondido aos três questionários solicitados durante o curso.

Para a coleta dos dados necessários foram utilizados três questionários, ferramentas de acompanhamento da participação e depoimentos dos alunos ao final do curso. Os dados foram colhidos no período que compreendeu o mês de novembro de 2007 a abril de 2008, pelos tutores presenciais e professores formadores junto aos municípios participantes.

O questionário 1 abordou questões de natureza pessoal e acadêmica dos alunos, bem como as concepções dos alunos em relação a surdez, a Libras e educação de pessoas surdas. 0 questionário 2 coletou informações referentes ao conhecimento dos alunos sobre a Libras e às expectativas quanto a realização do curso. 0 questionário final teve por objetivo registrar as opiniões dos participantes sobre a realização e conclusão do curso.

Além dos questionários, foram considerados como fonte de dados todo o percurso dos alunos no curso, as principais mensagens trocadas por e-mail e, também, todas as atividades desenvolvidas pelos alunos e suas respectivas participações no uso das ferramentas disponíveis no AVA. Essas foram, então, organizadas por cidade e, posteriormente, em uma tabela que buscou registrar o período/tempo de acesso e permanência no

\footnotetext{
12 Os municípios Itapecerica da Serra - SP, Muriaé - MG, e Tamboril - CE não enviaram os três questionários respondidos e, por este motivo, não foram levados em consideração na análise deste estudo.
} 
curso, e a realização das atividades propostas, tais como: a participação nas enquetes, fóruns, bate-papos e murais.

\section{Uma possível leitura dos dados: participação e avaliação do curso por parte dos sujeitos investigados}

O objetivo principal deste trabalho é investigar as contribuições do curso Librasnet, realizado na modalidade a distância, por meio da internet, para a formação continuada de professores da rede pública de ensino de dezessete municípios do Brasil, que atuam ou desejam atuar com a educação de pessoas surdas. Para o cumprimento desse objetivo, agrupamos os dados em dois eixos de análise: o perfil dos cursistas e sua avaliação em relação à participação no curso.

Para realização deste artigo foram analisados os dados de 96 professores, cursistas do "Professor e Surdez", sendo 94 participantes do sexo feminino e, apenas 2 do sexo masculino. Quanto às idades, $82 \%$ dos sujeitos investigados tinham entre 30 e 50 anos, o que demonstra um público maduro, com maior tempo de docência. Mais da metade dos professores $(53,1 \%)$ assumiam jornadas de trabalho acima de 40 horas semanais (dois turnos), e 10,4\% trabalhavam em três turnos. No que se refere à formação, 59,4\% possuíam Pós-graduação lato-sensu, e 31,3\% Graduação, o que revela um alto grau de formação dos participantes.

Constatamos que $100 \%$ desses sujeitos estavam vinculados à rede pública de ensino, e atuavam na docência da educação básica ${ }^{13}$. A maioria dos participantes $(55,6 \%)$ trabalhava no ensino fundamental, 3,3\%, na educação infantil, e 7,4\%, no ensino médio. Quanto à formação inicial dos sujeitos investigados, destacou-se em maior proporção, a Graduação em Pedagogia (64,8\%), seguida dos cursos de Letras $(10,3 \%)$ e História $(7,9 \%)$.

No que se refere às funções desempenhadas, constatamos que a maior parte das atividades estava concentrada na função docente, com um percentual de 67,1\% para professores; 8,3\% na orientação escolar, e $7,4 \%$ na direção escolar, embora tenham aparecido outras funções como fonoaudiólogo/a, psicólogo/a, auxiliar de secretaria, intérprete de Libras etc.

Outro dado importante é que $75 \%$ dos investigados concluíram o último nível acadêmico entre os anos de 2000 e 2008, ou seja, há menos de oito anos, indicando que a maioria deles está buscando sua atualização e

\footnotetext{
${ }^{13}$ A educação básica compreende a educação infantil ( 0 a 5 anos), o ensino fundamental ( $1^{\circ}$ ao 9 o ano), e o ensino médio ( $1^{\circ}$ ao $3^{\circ}$ ano).
} 
investindo na formação continuada. Apenas 5,2\% concluíram o último nível acadêmico antes de 1990. Em relação o tempo de experiência profissional, $68,7 \%$ dos participantes do curso contavam com mais de dez anos de docência e, apenas 10,4\%, menos de cinco anos. Ao restringir o tempo de atuação profissional à experiência na Educação Especial, foi encontrada uma média de 3,6 anos em relação aos 54 cursistas que confirmaram atuar na área, sendo que 27,8\% dos professores trabalhavam há apenas um ano com aluno/s com alguma deficiência física, sensorial ou intelectual, e apenas um participante trabalhava há 17 anos com alunos surdos.

Quanto aos tipos de deficiências atendidas nas escolas, a maioria $(42,9 \%)$ correspondia aos alunos surdos e/ou com diversas perdas auditivas, 23,8\% aos alunos com algum grau de deficiência intelectual, $14,3 \%$ aos alunos cegos e/ou com baixa-visão, 7,9\% aos alunos com algum tipo de deficiência física, 6,3\% aos alunos autistas e 4,8\% aos alunos com dificuldades de aprendizagem.

A maioria dos professores $(52,1 \%)$ que realizou o curso nunca havia participado de cursos na modalidade a distância, mas $45,8 \%$ já haviam cursado ou estavam realizando algum curso naquele período. Esse dado denota que grande parte dos alunos não tinha familiaridade com as tecnologias utilizadas no curso a distância, o que gerou alguns casos de desistência e dificuldades na execução das atividades.

Trinta e oito professores apontaram que a $\mathrm{EaD}$ serviria para atender as pessoas que não têm tempo disponível para se dedicar a um curso presencial, em razão das longas jornadas de trabalho. Dezenove professores destacaram que essa modalidade de ensino é uma oportunidade necessária para garantir a formação de pessoas que vivem longe das grandes cidades ou na zona rural. Seis professores destacaram que a EaD atende, também, pessoas que não têm condições financeiras para realizar um curso de formação presencial em suas cidades ou para se deslocarem para outras cidades em busca destes. A maioria dos professores apontou também que o bom desempenho nos cursos de EaD depende do interesse, da dedicação e do empenho do aluno, além do domínio de conhecimentos básicos na área da informática.

Um dado relevante é que as cidades participantes do curso localizamse em regiões do interior do país e são, em sua maioria, cidades pequenas, geralmente, na divisa territorial com outros estados, sendo a Educação a Distância, nestes casos, uma alternativa de ensino e aprendizagem para atender à demanda local.

Constatamos que 74 sujeitos já tiveram contato, em uma determinada situação e por períodos de tempo variados, com pessoas 
surdas. Vinte e cinco sujeitos já conheciam/utilizavam a Libras e trabalhavam com pessoas surdas, e treze tinham amigos surdos. Apenas um participante utilizava a Libras por ter pessoas surdas na família, e quatro sujeitos indicaram que conheciam a Libras e que, apesar de serem fluentes, tinham interesse em aprofundar seus conhecimentos para atender à demanda da inclusão.

Identificamos que vinte e cinco conheciam a Libras e já a utilizaram em diferentes situações do cotidiano, sendo que apenas um revelou que se comunicava facilmente por meio da Libras, pois atuava como intérprete. Todos os sessenta e seis sujeitos que não conheciam essa língua manifestaram interesse em aprendê-la em seus depoimentos iniciais. Em geral, a maioria dos depoimentos revelou que os professores estavam preocupados com a sua formação e buscavam, neste curso, discussões teóricas que pudessem contribuir com sua atuação docente.

Dentre os vinte e cinco professores que trabalhavam com alunos surdos, a maioria (15) atuava há mais de dois anos e, dez há apenas um ano, o que denota que esta ainda é uma experiência nova para eles.

No que se refere às condições disponíveis para a realização do curso, a maioria dos alunos $(87,5 \%)$ tinha um computador disponível para realizar as atividades, e somente $12,5 \%$ não tinham acesso a este. 0 local de maior acesso foi o ambiente doméstico $(66,7 \%)$, seguido do local de trabalho $(34,8 \%)$. Também houve casos de alunos que realizaram todo o curso em lan houses ou em residências de pessoas próximas (7,3\%). Para estes, a falta de um computador disponível influenciou negativamente o seu desempenho no curso.

Foi possível aferir que $71,9 \%$ dos participantes possuíam um horário disponível para acessar o curso, e apenas 28,1\% realizavam o curso em períodos variados de acordo com a disponibilidade. 0 período noturno foi revelado, pela maioria dos cursistas $(54,2 \%)$, como de maior acesso, seguido pelos períodos matutino e vespertino, com o mesmo percentual de acesso cada um $(18,6 \%)$.

Verificamos também que o tipo de conexão com a internet mais utilizada pelos sujeitos investigados foi a banda larga (80,2\%), e que $18,6 \%$ utilizaram a conexão discada. Apenas 1,1\% tinham internet via rádio. $82,7 \%$ consideraram que o tipo e a velocidade de conexão com a internet influenciou positivamente o seu desempenho no curso e 17,3\% julgaram que influenciou de forma negativa.

0 uso das ferramentas de comunicação presentes no AVA do curso Librasnet permitiram um processo de acompanhamento contínuo e 
gerenciamento da participação dos cursistas por parte do tutor a distância e do professor formador.

Verificamos que, dentre os sujeitos investigados, $61,5 \%$ utilizaram a ferramenta fórum, e 45,8\% a ferramenta mural. Diagnosticamos que essas ferramentas favoreceram a interação dos participantes, o sentimento de pertença ao grupo, a troca de ideias, questionamentos e dúvidas, a crítica e autocrítica, as discussões temáticas, a colaboração por meio da troca de experiências e a descoberta de muitos para a necessidade de continuar os estudos na área.

A partir das discussões realizadas no fórum foi possível perceber o envolvimento dos participantes investigados com o curso, isto é, com a educação de pessoas surdas, em especial, com a formação de professores. Além disso, demonstraram entendimento sobre a importância da Libras para a escolarização das pessoas surdas. A maioria dos cursistas associou as dificuldades da prática pedagógica com alunos surdos à falta de especialistas, de materiais adequados, às classes numerosas e aos salários defasados.

Identificamos que, dos participantes que tiveram acesso aos temas abordados no fórum, 6,7\% avaliaram o curso como "regular"; 21,6\% "bom", $45,9 \%$ "muito bom", e $25,7 \%$ avaliaram como "ótimo". Os que tiveram acesso aos temas abordados no mural, 2,3\% avaliaram como "fraco"; 10,3\% "regular", 21,8\% "bom", 41,4\% "muito bom", e 24,1\% avaliaram como "ótimo".

Para Santos (2003), a ferramenta fórum "permite o registro e a comunicação de significados por todo o coletivo por meio da tecnologia e permite que a mensagem circulada seja comentada por todos os sujeitos do processo de comunicação".

No que se refere ao uso do correio-eletrônico (e-mail), esta foi a principal forma da comunicação utilizada durante o curso. Grande parte das informações era trocada por meio dessa ferramenta: envio de textos para estudo, convites para participar nas outras ferramentas, relatórios de acompanhamento, avisos. Além disso, eram realizadas conversas esporádicas entre tutores, alunos e professores formadores.

Quanto à utilização da ferramenta bate-papo, intitulada neste curso como “Café com Libras", constatamos que 76,1\% dos sujeitos investigados tiveram, pelo menos, uma participação durante o curso. 0 foco do primeiro debate foi conhecer o perfil dos participantes do curso, o que já conheciam sobre a surdez, se já trabalhavam na área, quais recursos e materiais utilizavam, como era o trabalho em suas cidades etc. Todos os debates tinham um tema específico para ser aprofundado como, por exemplo: o 
Decreto n.. 5.626/2005, a inclusão de alunos surdos nas escolas regulares, a gramática da Libras. Dentre os $76,1 \%$ dos sujeitos que participaram dessa ferramenta, 43,8\% avaliaram como "ótimo" os temas abordados nos bate-papos, 37\% "muito bom", e 16,4\% como "bom".

De acordo com Santos (2003), os chats possibilitam uma comunicação todos-todos ou uma on-line mais reservada com qualquer participante - um-um. A comunicação no chat começa a partir da identificação com que o outro escreve, com suas ideias, não tendo como referências questões de aparência física, gênero, sexualidade etc., que, comumente, condicionam a sociabilidade em ambientes presenciais.

Cinquenta e quatro sujeitos investigados deixaram sugestões que se referem a elogios e/ou melhoria nessas ferramentas. A maioria $(70,3 \%)$ considerou que as ferramentas foram funcionais e/ou contribuíram para o esclarecimento de dúvidas. Alguns (16) participantes justificaram que o pouco uso da ferramenta bate-papo, por exemplo, deu-se devido à impossibilidade de participação no horário escolhido pela maioria da turma.

Quanto ao conteúdo apresentado no curso, 51,9\% dos participantes avaliaram como "ótimo", 42,6\%, "muito bom", e apenas 5,5\% como "bom". O conteúdo se refere a todos os itens visualizados nas lições, como sinais, frases, informações e exemplos em Libras, entre outros. 90,8\% dos sujeitos indicaram entre "muito bom" e "ótimo" a relação do conteúdo e formação de professores, e apenas 7,3\% consideraram como "regular".

Os conteúdos são ótimos, muito bem selecionados e bem condizentes com a realidade, são noções maravilhosas, ADOREI... (Sujeito 23).

O conteúdo do curso foi ótimo, as informações que obtive foram de grande aproveitamento 0 curso forneceu a base para um futuro aprimoramento em Libras (Sujeito 82).

Quanto à linguagem utilizada para a apresentação do conteúdo, 93,3\% dos cursistas avaliaram entre "muito bom" e "ótimo" e, apenas, 6,7\% como "bom": "Achei muito bom o curso ter usado uma linguagem do dia a dia, aumentando nosso vocabulário de Libras do próprio contexto" (Sujeito 12).

A utilização de desenhos 2D, para apresentação dos sinais do curso, foi avaliada por $71,3 \%$ dos participantes como "ótimo", e $24,2 \%$ como "muito bom". No que tange à visualização, 91,7\% dos cursistas indicaram entre "muito bom" e "ótimo" e, quanto à contextualização dos sinais, 95,7\% avaliaram entre "muito bom" e "ótimo". 
Foi indagado aos cursistas se eles haviam conseguido compreender os sinais apresentados durante o curso. $94,8 \%$ dos sujeitos investigados responderam "sim" e, apenas, 4,2\% "não". As dificuldades apontadas por estes últimos foram com relação ao tempo/velocidade para visualização do sinal, principalmente em frases. Um participante relatou que suas dificuldades estavam relacionadas às diferenças regionais, pois, em sua cidade, eram utilizados alguns sinais diferentes do curso.

Quanto à utilização de frases na estrutura da Libras, a maioria dos participantes $(71,3 \%)$ considerou entre "muito bom" e "ótimo" essa metodologia, 22,5\% "bom" e 6,2\% entre "regular" e "fraco". A maioria dos sujeitos apresentou dificuldades iniciais em compreender a construção das frases em Libras, dificuldade que, no decorrer do curso, foi sanada. A maioria dos sujeitos $(85,4 \%)$ afirmou que conseguiu compreender as frases na estrutura da Libras, e $14,6 \%$ não conseguiram. As principais justificativas para essa compreensão são apresentadas a seguir:

Sim, porque elas não estavam na ordem do português (Sujeito 66).

Tive dificuldades nas frases porque eram extensas e a explicação para mim deveria ser na ordem dos sinais (Libras) e depois em português (Sujeito 50).

No que diz respeito ao dicionário, a maioria dos participantes (95,3\%) atribuíram uma avaliação entre "muito bom" e "ótimo" à visualização deste em cada lição, com seus respectivos conceitos e configuração de mãos. Quanto aos assuntos abordados no "Você sabia?", $58,4 \%$ dos sujeitos avaliaram como "ótimo", 28,4\% "muito bom", e apenas $12,1 \%$ como "bom". No que se refere à usabilidade da plataforma, $29,9 \%$ consideraram como "bom", 38,5\% "muito bom", e 22,5\% como "ótimo".

A maioria dos sujeitos investigados $(95,8 \%)$ concordou com a metodologia de avaliação, e apenas $4,2 \%$ discordou. Dentre esses, $88,5 \%$ consideraram entre "muito bom" e "ótimo" o método de avaliação utilizado no curso. Quanto às atividades do "Aprenda brincando", 86,4\% dos cursistas avaliaram como "ótimo", e quanto à relação dessas com o conteúdo trabalhado, 94,8\% expressaram a mesma opinião. Por meio de respostas de 51 sujeitos, foi possível perceber que essas atividades se configuravam como o "momento preferido" dos participantes do curso.

Achei o "Aprenda brincando" excelente, aproveitei o máximo e podíamos treinar quanto vezes desse vontade. A cada lição eu ficava esperando a surpresa que viria quando aparecia um "Aprenda brincando" (Sujeito 13).

64 - Lázara Cristina da Silva | Marisa Pinheiro Mourão | Wender Faleiro da Silva 
Com relação à avaliação realizada por meio dos "Testes de verificação", 77,1\% dos participantes indicaram como "ótimo". Quanto ao uso de perguntas com sinais e alternativas em Língua Portuguesa nos testes, a maioria (66,7\%) avaliou como "ótimo", e 58,3\% expressaram com o mesmo indicador a sua opinião sobre o uso de perguntas com frases em Libras e alternativas em Língua Portuguesa. Já a avaliação da compreensão dos enunciados utilizando sinais foi maior $(58,3 \%)$ do que os enunciados utilizando frases em Libras $(34,4 \%)$.

A maioria dos cursistas que justificou a sua opinião sobre a avaliação utilizada, considerou que, em geral, ela foi "proveitosa", "contribuiu para ampliar o conhecimento", "foi criativa e de fácil compreensão".

0 curso proporcionou ao aluno diferentes formas de avaliação como: testes de verificação; estudo dirigido; mural; fórum; chats; enquetes; dinâmica da caixinha. Isso enriqueceu muito o curso, tornando-o mais envolvente (Sujeito 14).

Ao final do curso, foi elaborado um relatório geral de desempenho por cidades, o qual constava a nota dos 36 testes realizados pelos alunos e o seu desempenho final, bem como o seu percentual de acesso. A média final de horas de estudo na plataforma foi de $34 \mathrm{~h}$ e $46 \mathrm{~min}$, sendo que $26 \%$ contabilizaram menos de 20 horas de estudo, e 11,5\% acima de 50 horas. No que se refere à média final de desempenho nas atividades, a média foi de $91 \%$, e apenas dois cursistas não conseguiram obter $70 \%$.

Quanto ao desempenho obtido no curso, a maioria dos cursistas $(94,8 \%)$ considerou que os resultados corresponderam às suas expectativas, e apenas 5,2\% não ficaram satisfeitos. 98,9\% dos sujeitos investigados indicaram que estavam satisfeitos com o curso. 0 único cursista que manifestou não estar satisfeito com o curso, apresentou a justificativa de que o mesmo não fornecia uma "sustentação sólida para formar o professor bilíngue" (Sujeito 81). Convém esclarecer que este não era o objetivo do curso.

Algumas opiniões sobre o grau de satisfação com o curso, que apareceram com maior frequência nos depoimentos, estavam relacionadas à ludicidade na apresentação do conteúdo, à contextualização dos sinais e à diversidade de atividades e conteúdos propostos no curso.

o curso foi muito bem elaborado, com imagens perfeitas e de grande qualidade, os sinais são super fáceis de entender e, na verdade, até sentirei saudades desta família do Dudu que tanto me ensinou (Sujeito 22). 
Achei o curso de excelente qualidade, de fácil entendimento, com exercícios muito bem elaborados [...]. Tenho uma filha surda, trabalho com surdos e quanto eles viram adoraram os desenhos, queriam fazer também (Sujeito 3).

Dois cursistas relacionaram a importância deste curso devido à falta de um profissional surdo para ensinar Libras em suas cidades: "Agradeço a oportunidade que vocês me proporcionaram em fazer o curso de Libras, o qual não é de fácil acesso na cidade em que resido" (Sujeito 88). Outro ponto destacado por dezesseis cursistas foi à contribuição do curso nas atividades escolares e na comunicação com alunos e demais pessoas surdas.

Oito participantes apontaram que o curso proporcionou uma nova compreensão a respeito da surdez, da Libras e da educação de pessoas surdas.

O Librasnet ampliou meus horizontes e meu conhecimento em relação a Libras com uma língua bem difícil de aprender. Este curso me mostrou que uma educação bilíngue tem que ser uma realidade presente no espaço escolar. Essa língua Libras tem que estar acessível a todas as crianças independentemente de ser surdo ou não. É maravilhoso conhecer outra língua, estou muito triste de terminar o curso, o Dudu fez parte da minha vida todo este tempo de aprendizado [...] (Sujeito 84).

Para 15 cursistas, o curso despertou o interesse em aprofundar os estudos sobre esse tema. Em algumas falas, expressaram o desejo de realizar cursos de Libras na modalidade presencial, em outras, o desejo de realizar uma Graduação ou Pós-graduação nesta área, e ainda de se tornar um intérprete dessa língua.

Tive uma oportunidade única de aprender, aliás iniciar na aprendizagem de Libras em alto estilo, porque quero muito fazer outros cursos. Vocês são perfeitamente maravilhosos no que se propõem a fazer (Sujeito 63).

Adorei fazer este curso, foi excelente. Quero continuar estudando mais e mais, e fazer uma pós na área de Libras. Estou triste que o curso acabou, mas feliz pela oportunidade que tive de aprender um pouco de Libras [...] (Sujeito 31)

No depoimento final, todos os cursistas investigados agradeceram a oportunidade de ter participado do curso, e apontaram a realização do curso como um fator importante na sua formação profissional. Em 21 
falas, foi possível diagnosticar o interesse dos participantes em cursar outros módulos, caso esses viessem a ser oferecidos. Outros disseram que sentiriam "saudade" dos personagens, especialmente, do Dudu.

Parabéns a equipe organizadora e todos que tiveram envolvidos nesse projeto, e gostaria de dar continuidade neste curso porque sei que foi só o começo porque tenho muito a aprender e conto com uma nova oportunidade (Sujeito 1).

Quando soube que o DUDU iria se despedir na lição no 9, protelei por uma semana até concluí-la e quanto ele se despediu, senti um aperto no peito. Não acreditei no que senti. Ele praticamente já fazia parte de nossa família. Foi realmente muito bom interagir com ele e a família dele (Sujeito 65).

Sendo assim, podemos considerar que o curso, para a maioria dos participantes, contribuiu para o aprendizado da Libras e para a sua formação profissional com vistas à atuação na educação de pessoas surdas. Diagnosticamos também um grande interesse desses sujeitos em colocar em prática os conhecimentos adquiridos, de rever e modificar suas práticas e dar continuidade ao aprendizado da Libras.

\section{Considerações finais}

As reflexões realizadas nesse estudo tiveram como objetivo a investigação e a análise das contribuições do curso Librasnet como uma ferramenta para a formação continuada de professores da rede pública de ensino que atuavam ou desejavam atuar com a educação de pessoas surdas.

Este estudo abrangeu um público formado, em sua maioria, por pessoas entre 30 e 50 anos. Esse dado revelou que os profissionais tinham maior tempo de docência e especialização profissional, e que a maioria contava com mais de dez anos de experiência na área educacional. Outro importante dado descoberto foi que, apesar da dupla ou tripla jornada de trabalho, os sujeitos investigados estão buscando a sua atualização e investindo em sua formação continuada.

Primeiramente, acreditamos que é preciso viabilizar o desejo dos surdos de construir saberes, identidades e culturas a partir da sua língua natural, sem desconsiderar, no entanto, a língua oficial do seu país. Acreditar nessa possibilidade implica em diversas rupturas, mudanças de 
concepções e, sobretudo, no reconhecimento dessa língua na educação dos surdos, o que recai, "naturalmente", na viabilização da Libras em todo o processo de comunicação desses sujeitos, e destes, com as pessoas com os quais se relacionam, inclusive com o professor.

A maioria dos participantes do curso acreditava que o processo de escolarização de pessoas surdas é indispensável e demanda uma formação inicial e continuada de qualidade que forneça sustentação às práticas escolares. Entretanto, o reconhecimento da Língua de Sinais (Libras) nem sempre é uma tarefa fácil. Nos espaços escolares, implica uma condição de aprendiz por parte do professor. Esse processo requer profissionais dispostos a investir na sua formação para que possamos consolidar uma educação significativa, com a equiparação de oportunidades e o exercício pleno dos direitos de cidadão da pessoa surda.

Outra questão importante verificada neste estudo foi com relação às concepções dos cursistas sobre a educação de pessoas surdas. As respostas obtidas revelaram que a maioria não conhecia a Libras, mas que já tinham tido contato com pessoas surdas na escola onde atuavam e, por esse motivo, manifestaram o desejo de aprender essa língua, e adquirir conhecimentos nessa área. Essas concepções serviram como ponto de partida para as discussões que foram realizadas no ambiente de aprendizagem do curso, por meio das ferramentas de comunicação. Tais ferramentas foram frequentemente utilizadas pelos cursistas e serviram para aprofundar e discutir temas relevantes sobre a educação de surdos, para o esclarecimento de dúvidas, expressão de anseios, angústias e partilha de informações.

Por meio das opiniões expressas nas ferramentas de comunicação do AVA, foi possível perceber que os participantes, ao longo do curso, foram complementando, ampliando e/ou modificando as suas concepções a respeito da educação de pessoas surdas, da Libras, da formação de professores e, também, da importância da confluência dessas no desenvolvimento desses sujeitos. Foi possível chegar a essas considerações realizando comparações entre as opiniões expressas ao longo do curso com aquelas apresentadas em seu início, as quais revelaram que a maior parte dos sujeitos investigados tinha pouco, ou nenhum, conhecimento sobre essa área.

A maioria dos participantes avaliou de forma positiva o uso dessas ferramentas de comunicação, bem como os temas abordados e a relação desses com a formação de professores, e destacaram ainda a funcionalidade das mesmas para o esclarecimento de dúvidas, troca de informações, para o seu bom desempenho no curso. No entanto, no que 
se refere à autoavaliação, muitos participantes afirmaram que devido às longas jornadas de trabalho, a participação assídua nas atividades do curso foi prejudicada.

Quanto à conclusão do curso, a avaliação final expressa pelos participantes, apontou que o curso atendeu às necessidades básicas do público em questão, formado, em sua maioria, por professores em atuação. Os principais aspectos mencionados foi a metodologia utilizada, o uso de imagens para a visualização dos sinais, o ambiente de aprendizagem atrativo e a contextualização do conteúdo. As principais dificuldades apresentadas foram com relação à usabilidade da plataforma no início do curso, à compreensão das frases na estrutura da Libras, ao prazo estabelecido para a realização do curso, à memorização dos sinais e, principalmente, às dificuldades de ordem técnicas, como a falta de um computador com acesso à internet, e também domínio da informática.

Em um primeiro momento, o curso causou expectativas, receios, tensão e questionamentos. Em outro, causou impacto, impasse, novidade, vontade de aprender, de fazer, de mudar, de se comunicar. Ainda para outros, ampliou o hábito de leitura de textos ao serem convidados a fazer uma leitura de "sinais e expressões" em um Ambiente Virtual de Aprendizagem - AVA.

Em síntese, a maioria dos cursistas considerou que o curso despertou o interesse para o aprendizado da Libras e a necessidade de continuar se aperfeiçoando, estudando e pesquisando sobre essa língua. Outros aspectos destacados foram: o conhecimento da realidade educativa dos surdos brasileiros; a revisão e o esclarecimento de conceitos, saberes e práticas da educação de surdos; o conhecimento de diferentes sinais utilizados em outras regiões do país; a compreensão das estratégias e materiais específicos para o trabalho com o aluno surdo; o enriquecimento do vocabulário da Libras e a facilitação da compreensão da sua gramática. Os alunos/cursistas também fizeram referência à contribuição do curso para o crescimento pessoal e profissional, revelando, ainda, a preocupação e o desejo de colocar em prática os conhecimentos adquiridos. E, por fim, para $98,9 \%$ dos sujeitos investigados, o curso cumpriu com o objetivo de formação continuada em Educação Especial na área da surdez. 


\section{Referências}

BELLONI, M. L.. Educação a Distância. 4. ed. Coleção Educação Contemporânea. Campinas: Autores Associados, 2006.

BRASIL. Decreto n.o 5626, de 22 de dezembro de 2005. Brasília: Presidência da República, Casa Civil, Subchefia para Assuntos Jurídicos. Disponível em: <http:// www.planalto.gov.br/ccivil_03/_Ato2004-2006/2005/Decreto/D5626.htm.> Acesso em: 04 fev. 2009.

BRASIL. Decreto-Lei $n^{\circ} \stackrel{0}{5.622}$ de 19 de dezembro de 2005. Regulamenta o art. 80 da Lei no 9.394, de 20 de dezembro de 1996. Disponível em: <http://portal.mec. gov.br/sesu/arquivos/pdf/portarias/dec5.622.pdf>. Acesso em: 02 fev. 2009.

BRASIL. Lei n. 10.436, de 24 de abril de 2002. Dispõe sobre a Língua Brasileira de Sinais - Libras e dá outras providências. Disponível em: <http://portal.mec.gov. br/seesp/arquivos/pdf/lei10436.pdf> Acesso em: 04 fev. 2009.

CAPOVILLA, F. C.; RAPHAEL, W. D.. Dicionário Enciclopédico Ilustrado Trilíngue da Língua de Sinais Brasileira, v. 1: Sinais de A a L. 3 ed. São Paulo: Editora da Universidade de São Paulo, 2001.

CORADINE, L. C., ALBUQUERQUE, F. C., BRITO, P. H. S., SILVA R. L., SILVA, T. F. L. Sistema FaLibras: Interpretação animada, em LIBRAS, de palavras e expressões em português. In: Congresso Ibero-Americano de Informática na Educação Especial, 2, 2002, Fortaleza. Anais do II Congresso Ibero-Americano de Informática na Educação Especial, CIIEE, Fortaleza, 2002.

COSTA, E. B.; JUNIOR, M.; PAES, R.; LEITE, C. graW: A Web Interactive Environment to Support Undergraduate Courses. Proceedings of the World Conference on E-Learning in Corporate, Government, Healthcare, \& Higher Education - E-Learn 2002. Montréal, Canadá, 2002.

DORZIAT, A. Bilinguismo e surdez: para além de uma visão linguística e metodológica. In: SKLIAR, C. (org.). Atualidade da educação bilíngue para surdos. Porto Alegre: Mediação, 1999.

FELIPE, T. A.. Introdução à Gramática de Libras. In: BRA SIL, Secretaria de Educação Especial. Educação Especial: Deficiência Auditiva. Org. RINALDI, G. et al. Série Atualidades Pedagógicas. n.ํ 4, v 1. Brasília MEC/SEESP, 1997.

FELIPE, T. A.; MONTEIRO, M. S.. Libras em Contexto: curso básico, livro do professor instrutor. Brasília: Programa Nacional de Apoio à Educação dos Surdos, MEC/ SEESP, 2001.

FERNANDES, E. Linguagem e Surdez. Artmed, 2003.

FERREIRA BRITO, L.. Estrutura Linguística da Libras. In: BRASIL, Secretaria de Educação Especial. Educação Especial: Deficiência Auditiva. Org. RINALDI, G. et al. Série Atualidades Pedagógicas, n.ํ 4, v. 1. Brasília: MEC/SEESP,1997.

KENSKI, V. M.. O Desafio da Educação a Distância no Brasil. Revista Educação em Foco Educação a Distância. Juiz de Fora, UFJF. Vol. 7, no 1, 2002. Disponível em: <http:// www.ufjf.br/revistaedufoco/files/2010/02/011.pdf>. Acesso em: 04 fev. 2009.

70 • Lázara Cristina da Silva | Marisa Pinheiro Mourão | Wender Faleiro da Silva 
LIRA, G. A.. Boletim Técnico do Senac. 0 impacto da tecnologia na educação e inclusão social da pessoa portadora de deficiência auditiva: TLibras tradutor digital Português x Língua Brasileira de Sinais - Libras. Rio de Janeiro. v. 29, n. 3, p. 42-51, dez., 2003.

MISSENO, E.; CARVALHO, R. M. A.. Curso de Língua Brasileira de Sinais - Libras on-line: relato de uma experiência. Congresso Iberoamericano de Informática Educativa, 7, 2003, Monterrey, México, Anais do VII Congresso Iberoamericano de Informática Educativa, Monterrey, México, 2003. p. 1143-1147. Disponível em: <http://libra.niee.ufrgs.br/niee/eventos/RIBIE/2004/breve/breves1143-1147. pdf> Acesso em: 01 jan. 2009.

MORAN, J. M.. A educação que desejamos - novos desafios e como chegar lá. 1. ed. Campinas: Papirus, 2007.

QUADROS, R. M.. Situando as diferenças implicadas na educação de surdos: inclusão/ exclusão. Florianópolis: Ponto de Vista, n.ํㅜ 5, 2004.

QUADROS, R. M.; KARNOPP, L. B.. Língua de Sinais brasileira: Estudos linguísticos. Porto Alegre: Artes Médicas. 2004.

ROMANELLI, G.; BIASOLI-ALVES, Z. M. M. Diálogos Metodológicos sobre Prática de Pesquisa - Programa de Pós-graduação em Psicologia da FFCLRP USP/CAPES; Ribeirão Preto: Ed. Legis - Summa, 1998.

SÁ, N. R. L.. Cultura, poder e educação de surdos. São Paulo: Paulinas, 2006.

SANTOS, E. O. Articulação de saberes na EAD online. In: SILVA, M. (Org.). Educação online: teoria, práticas, legislação corporativa. São Paulo: Edições Loyola, 2003, p. 219-321.

SKLIAR, C. B. (Org.). Educação e exclusão: abordagem sócio-antropológica em educação especial. Porto Alegre: Mediação, 1998.

STROBEL, K. L. FERNANDES, S. Aspectos linguísticos da Língua Brasileira de Sinais. Secretaria de Estado da Educação. Superintendência da Educação. Departamento de Educação Especial. Curitiba: SEED, SUED, DEE, 1998. 


\section{CAPÍTULO IV \\ EDUCAÇÃO DE ALUNOS SURDOS NA PERSPECTIVA \\ INCLUSIVA: LIMITES E POSSIBILIDADES NAS ESCOLAS PÚBLICAS BRASILEIRAS}

Ana Carolina Caetano Arantes ${ }^{1}$

Vilma Aparecida de Souza ${ }^{2}$

O presente trabalho tem como objeto de investigação a atual política de formação docente para a Educação Especial instituída por meio da oferta de Cursos de Formação Continuada para Professores na área da Educação Especial/Inclusiva por meio da Rede Nacional de Formação de Professores em Educação Especial do Ministério da Educação, criada em 2008. O foco principal do estudo é o Curso de Atendimento Educacional Especializado para Alunos Surdos oferecido na Plataforma Freire.

O contato com os cursos da Plataforma Freire, na área da Educação Especial/ Inclusiva, trouxe à tona algumas inquietações: quais os avanços e recuos enfrentados na dinâmica do trabalho docente, em relação às políticas de Educação Especial voltadas para a inclusão de alunos surdos? Quais desafios postos para a promoção de um ensino de qualidade para os todos os alunos no âmbito da escola regular?

Considerando essas questões norteadoras, o presente trabalho tem como objetivo analisar os limites e as possibilidades encontrados na dinâmica do trabalho docente, frente às políticas de Educação Especial implementadas nos diferentes municípios brasileiros, em relação à educação de alunos surdos nas escolas públicas brasileiras, a partir das percepções dos professores que participaram de cursos de formação continuada na modalidade à distância, pela Plataforma Freire, em especial o curso "Atendimento Educacional Especializado para Pessoas Surdas - Turma I".

\footnotetext{
${ }^{1}$ Aluna do Curso de Pedagogia da Faculdade de Ciências Integradas do Pontal, Curso de Pedagogia da Universidade Federal de Uberlândia. Membro do Grupo de Pesquisa GEPEPES - Grupo de Estudos e Pesquisas Políticas e Práticas em Educação Especial.

${ }^{2}$ Professora do Curso de Pedagogia da Universidade Federal de Uberlândia- FACIP - Faculdade de Ciências Integradas do Pontal. Professora Formadora do Curso de Aperfeiçoamento Educação Especial e Atendimento Educacional Especializado. Membro do Grupo de Pesquisa GEPEPES - Grupo de Estudos e Pesquisas Políticas e Práticas em Educação Especial.
} 
O Curso "Atendimento Educacional Especializado para Pessoas Surdas - turma I" faz parte da Rede Nacional de Formação Continuada de Professores na Educação Especial, inserido no âmbito da Secretaria de Educação Continuada, Alfabetização, Diversidade e Inclusão/MEC SECADI/MEC, e foi promovido pela Universidade Federal de Uberlândia - UFU, por meio do Centro de Ensino, Pesquisa, Extensão e Atendimento em Educação Especial - CEPAE.

O Curso Atendimento Educacional Especializado para Pessoas Surdas - Turma I, no âmbito do Programa UAB, foi oferecido como um curso de extensão destinado a 1.000 profissionais na rede pública de ensino. Consiste na oferta de um curso de Educação a Distância via web, com o objetivo de oferecer formação continuada para professores que atendem e/ou pretendem atender alunos surdos, na modalidade de Atendimento Educacional Especializado - AEE. A forma de interação e comunicação entre tutores e alunos foi, exclusivamente, no Ambiente Virtual de Aprendizagem - AVA Moodle.

O AVA Moodle apresenta diversas ferramentas tais como: fórum de discussão, diário de bordo, chat e envio de tarefa. Além dessas ferramentas, o curso solicitou que os professores cursistas respondessem a dois questionários ao longo do curso com questões abertas e fechadas com o objetivo de conhecer os participantes e de avaliar o trabalho realizado.

Em relação aos procedimentos metodológicos, para atingir os objetivos deste estudo, em um primeiro momento, foi realizada uma pesquisa bibliográfica, com a finalidade de realizar o aprofundamento do referencial teórico que embasou a pesquisa e as análises dos dados levantados.

Já em um segundo momento, uma pesquisa documental foi realizada com o intuito buscar nos documentos oficiais informações sobre as políticas nacionais de formação continuada de professores. A pesquisa documental permitiu identificar informações e subsídios descritivos em documentos, uma vez que estes constituem uma fonte rica de dados de pesquisa.

Além disso, foi analisada uma amostra de questionários e dos fóruns de discussão realizados ao longo da execução dos cursos de formação continuada da Plataforma Freire. A amostra selecionada é composta por três turmas, totalizando 31 professores. Nesse processo, foi garantido o anonimato dos sujeitos envolvidos por meio do uso de algarismos para identificação.

0 trabalho foi estruturado em três momentos. No primeiro, discute-se sobre a Educação Inclusiva, buscando enfocar sua abrangência e pressupostos legais. Em seguida, aborda-se a dimensão da educação de surdos, enfocando as políticas de inclusão educacional, em especial 
as destinadas aos alunos surdos. Por fim, passa-se a analisar a prática pedagógica que vem sendo materializada nas escolas públicas na educação de pessoas surdas, colocando em relevo as percepções de professores de municípios brasileiros acerca das ações implementadas para esse fim, dentre elas a implantação do AEE, como exigência legal em decorrência da Política Nacional de Educação Especial na Perspectiva da Educação Inclusiva e do Decreto n.․ 6.571, de 17 de setembro de 2008.

\section{Educação Inclusiva: marcos conceituais e legais}

Os processos de escolarização das pessoas com deficiência, transtornos globais do desenvolvimento e altas habilidades/superdotação, público da Educação Especial, no âmbito brasileiro, desde 2008, recebeu sustentação com a Política Nacional de Educação Especial na Perspectiva da Educação Inclusiva - PNEE. O documento que oficializa a PNEE apresenta as novas diretrizes no sentido de subsidiar as práticas educacionais nas escolas de nosso país.

As diretrizes da PNEE apontam para a reorganização dos sistemas de ensino de forma a superar a organização paralela de Educação Especial; a garantir o acesso à escolarização na sala de aula comum do ensino regular e a oferta do AEE complementar aos alunos da Educação Especial. A atual política mantém a transversalidade da Educação Especial expressa nas Diretrizes Nacionais da Educação Especial de 2002, a fim de assegurar as mesmas oportunidades de aprendizagem para todos os alunos e não incorporar a existência de escolas e/ou classes especiais por categorias, e a oferta de educação segregada historicamente presente na educação nacional.

A proposição da atual PNEE reflete a ampla discussão realizada nos diversos fóruns educacionais sobre inclusão no país, as conquistas do movimento das pessoas com deficiência, bem como os avanços dos marcos legais e educacionais. 0 documento configura a Educação Inclusiva como uma ação política, cultural, social e pedagógica em defesa do direito de todos a uma educação de qualidade e da organização de um sistema educacional inclusivo.

A PNEE tem a meta de assegurar direitos que até então não foram plenamente assumidos pela educação brasileira. Tal posição políticoeducacional sustenta-se na necessidade de modificar os atuais sistemas de ensino, no sentido de convergir para uma concepção de ensino e aprendizagem que tenha como norte o reconhecimento das diferenças humanas, uma vez que 
Não se trata de pensar tão somente a educação para o deficiente, mas, sobretudo, de basilar a prática educativa e a organização da escola no respeito à diferença do outro. E é nesse princípio, de defesa da escolarização, que essa política tem seu suporte e sua justificativa (FREITAS, 2008, p. 22).

A PNEE reforça o sentido da Educação Especial no qual integra o sistema de ensino, em que sua especificidade passa a compor-se de forma articulada à educação comum (Freitas, 2008). Essa posição decorre de um amplo processo de discussão que

buscou contemplar os diferentes órgãos representativos da educação especial do País. Esse processo permitiu avançar a discussão, tendo em vista a superação do paradigma integracionista e do entendimento assistencialista que permeou historicamente as práticas em educação especial (Freitas, 2008, p. 32).

Fomentando a questão discutida, é importante destacar que a PNEE visa uma ação política, cultural, social e pedagógica, desencadeada em defesa do direito de todos os alunos de estarem juntos, aprendendo e participando, sem nenhum tipo de discriminação.

Tal política define ainda que

a educação especial, na perspectiva da educação inclusiva, deve ser inserida na proposta pedagógica da escola regular, assegurando o atendimento às necessidades educacionais especiais de alunos com deficiência, transtornos globais de desenvolvimento e altas habilidades/superdotação (Brasil, 2007, p. 9).

Nesse sentido, reforçando a determinação da Lei n.ำ 9394/96, Lei de Diretrizes e Bases da Educação Nacional, a Educação Especial é compreendida como uma modalidade de ensino que perpassa todos os níveis, etapas e modalidades, por meio do AEE, serviço que deve oferecer recursos e orientações de forma articulada com o ensino regular.

Entretanto, o AEE já constava na Lei de Diretrizes e Bases da Educação Nacional de 1996. No Artigo 58 estabelece que

Art. 58. Entende-se por educação especial, para os efeitos desta Lei, a modalidade de educação escolar, oferecida preferencialmente na rede regular de ensino, para educandos portadores de necessidades especiais.

$\S 1$ ํ Haverá, quando necessário, serviços de apoio especializado, na escola 
regular, para atender às peculiaridades da clientela de educação especial (Brasil, 1996, p. 5).

A Educação Inclusiva exige novos modelos pedagógicos que levem em consideração as potencialidades e capacidades dos alunos, indo além do foco nas limitações e dificuldades, como acontece no modelo tradicional de educação.

Não se trata de negar a deficiência, no caso dos alunos com impedimentos, em longo prazo, de natureza física, mental ou sensorial, mas de saber e reconhecer que há um ser humano para além da deficiência. Isto é, trata-se de compreender e prever que diferenças exigem diferentes intervenções pedagógicas e diferentes olhares, sem, contudo, diminuir o que se pode ensinar, e sem subestimar o aluno e suas reais possibilidades de exercer sua cidadania. Isso significa não permanecer com uma visão "engessada" sobre a deficiência.

Nessa direção, Mantoan (1998, p. 25) afirma que

Incluir, então, significa integrar um aluno ou um grupo na educação regular, o que lhe é de direito, num espaço que possibilite exercer a cidadania e ter acesso aos diferentes saberes. A inclusão não se limita a ajudar somente os alunos que apresentam dificuldades na escola, mas apóia toda a comunidade escolar.

A inclusão é um processo imprevisível, não existem fórmulas/ regras prontas. Existem sim, algumas certezas como, por exemplo, que a homogeneidade na sala de aula não existe. A expressão "todos somos iguais" é apenas uma frase de efeito que busca ignorar as diferenças humanas. Na realidade, a inclusão não tem como meta tornar todos "iguais", mas, ao contrário, entende as diferenças como resultantes da multiplicidade. Trata-se de uma educação que "garante o direito à diferença" (Mantoan, 2010, p. 19).

Nessa direção, um elemento central refere-se à formação de professores para a Educação Inclusiva, o que implica o domínio de conhecimentos para atuar em diferentes situações escolares capazes de atender à diferença humana. Falar em formação de professores na perspectiva de Educação Inclusiva é pensar em um assunto que merece especial atenção, no sentido de ser um dos requisitos para a implementação desse paradigma educacional. Além disso, as lacunas encontradas na questão da formação de professores na perspectiva da Educação Inclusiva podem contribuir para que o ambiente da escola regular não seja tão inclusivo assim. 
De acordo com Mendes (2006), faltam condições básicas para assegurar não somente o acesso, mas a permanência com qualidade desses alunos - público da Educação Especial nas escolas comuns. Dentre essas condições, destacam-se muitos fatores que comprometem o trabalho docente que vem sendo materializado nas escolas públicas na educação de pessoas surdas.

\section{A educação das pessoas surdas: ranços e avanços no contexto da Educação Inclusiva}

Uma retrospectiva histórica da educação das pessoas surdas permite verificar a predominância por muitos anos da filosofia Oralista que visava a "reabilitação" da criança surda na comunidade de ouvintes, impondo-lhe a língua oral por meio da estimulação de práticas de oralização.

Outra fase da educação de surdos é delineada com o método de Comunicação Total. 0 método de Comunicação Total aparece em 1968. A Comunicação Total também tem como frente de trabalho a aprendizagem da língua oral pela criança surda, mas defende também a utilização de recursos espaciais-visuais como facilitadores da comunicação (Goldfeld, 2001).

Nos anos 1980 ganha força a Proposta Bilíngue de Educação do Surdo. Segundo essa proposta, o surdo vive numa condição bilíngue e bicultural, ou seja, convive com duas línguas e duas culturas: a língua e a cultura da comunidade surda do seu país, juntamente com a língua oral e cultura ouvinte de seu país. 0 bilinguismo tem como pressuposto que a língua de sinais seja ensinada, desde a infância, como primeira língua para o surdo, sendo a língua oral oficial do seu país ensinada, como segunda língua.

Assim, para o bilinguismo, o surdo precisa aprender primeiramente a língua de sinais, sendo reconhecida como sua língua materna e natural (Goldfeld, 2001).

Entretanto, a escola regular por muitos anos encaminhou sua prática pedagógica nos moldes da filosofia Oralista, fato este que deixou muitos ranços e um legado de exclusão do aluno surdo, uma vez que inúmeras vezes a cultura e a identidade do surdo não foram valorizadas.

Para Mantoan, a inclusão envolve uma nova perspectiva educacional e "as escolas atendem às diferenças sem discriminar, sem trabalhar à parte com alguns alunos" (2003, p. 25). Nesse sentido, a escola regular não vem sendo "inclusiva", isto é, não tem levado em consideração a educação de surdos, pois a maioria dos professores da sala regular não 
possui capacitação para atender o surdo na sala de aula e, dessa forma, a "diferença linguística" tende a ser desrespeitada e desconsiderada. As práticas pedagógicas desses professores são pautadas na linguagem oral, o que provoca o desinteresse e a exclusão do aluno surdo.

Assim, apesar do debate acerca da inclusão escolar e da garantia legal, muito ainda precisa ser avançado em termos de políticas educacionais, para que seja promovido e assegurado o processo de inclusão escolar do aluno surdo.

Muitos profissionais da educação não possuem uma formação inicial e continuada voltada para educação de surdos. Tal formação pode contribuir para que esse aluno esteja submetido às práticas pedagógicas e aos mecanismos diversos que negam a condição de ser do sujeito surdo, não reconhecendo suas necessidades mais elementares, privandolhe de oportunidade para o desenvolvimento e o fortalecimento de sua identidade pessoal (Skliar, 2000).

Além disso, Skliar (2000) ao tratar da formação do professor, ressalta a dimensão política dessa formação. Para o autor, a política é compreendida como relação de poder e conhecimento que deve estar contemplada, não só na proposta pedagógica, mas além dela.

Na formação do professor para educação de surdos, em relação a escola inclusiva, ele considera relevante, em primeiro lugar, os significados políticos que circulam sobre a surdez e os surdos presentes nas escolas. Considera, também, a "questão da língua de sinais", as identidades, a comunidade, a cultura e o acesso dos surdos às segundas línguas (Skliar, 2000, p. 162).

Assim, a formação do professor, que tem como preocupação essas questões, deve compreender a história dos sujeitos surdos, as restrições sociais, familiares e escolares. Esses sujeitos sempre foram submetidos aos nexos políticos com a sociedade e às formas de constituição do saber escolar, que resgatam a educação como um bem social ao terem acesso a um ensino de qualidade. Todos são humanos e o que diferencia os sujeitos são suas características específicas. Portanto, incluir todas as pessoas é um bem que fazemos para a humanidade, e essa ação pode ser iniciada a partir da conscientização plena de todos.

Além desse aspecto, outra lacuna na formação docente em relação à educação de surdos, refere-se ao domínio da Libras.

0 Decreto $n$. .5 .626 , de 22 de dezembro de 2005, que dispõe sobre a Língua Brasileira de Sinais (Libras), traz várias ações a serem implementadas gradualmente nos próximos dez anos, período necessário 
para realizar a capacitação de profissionais. Esse decreto prevê, dentre vários outros aspectos,

Art. 15. Para complementar o currículo da base nacional comum, o ensino de Libras e o ensino da modalidade escrita da Língua Portuguesa, como segunda língua para alunos surdos, devem ser ministrados em uma perspectiva dialógica, funcional e instrumental, como:

I - atividades ou complementação curricular específica na educação infantil e anos iniciais do ensino fundamental; e

II - áreas de conhecimento, como disciplinas curriculares, nos anos finais do ensino fundamental, no ensino médio e na educação superior.

Art. 16. A modalidade oral da Língua Portuguesa, na educação básica, deve ser ofertada aos alunos surdos ou com deficiência auditiva, preferencialmente em turno distinto ao da escolarização, por meio de ações integradas entre as áreas da saúde e da educação, resguardado o direito de opção da família ou do próprio aluno por essa modalidade (Brasil, 2005, p. 3).

Considerando essa exigência legal, verifica-se que muitas escolas públicas brasileiras encontram dificuldades para implementar o referido decreto, considerando que muitos de seus profissionais não possuem formação bilíngue.

A questão da formação docente, somando-se a outros fatores, compromete a prática pedagógica que vem sendo materializada nas escolas públicas na educação de pessoas surdas. A seguir, serão apresentadas as análises dos dados acerca dos limites e das possibilidades da prática pedagógica docente em relação à educação de alunos surdos nas escolas públicas brasileiras, a partir das percepções dos professores que participaram do curso de formação continuada "Atendimento Educacional Especializado para Pessoas Surdas - turma I”.

\section{Limites e possiblidades na dinâmica do trabalho docente em relação à educação de alunos surdos: a vez e a voz dos professores das escolas públicas brasileiras}

Considerando o exposto até aqui, pode-se evidenciar que para a materialização de uma Educação Inclusiva, conforme defendido por um movimento tanto internacional como nacional, mesmo sendo ratificado de forma mais radical em 2007 na PNEE, ainda encontra muitos desafios, considerando a realidade das escolas públicas brasileiras. 
Além disso, Carvalho (2010) afirma que, passados muitos anos após a aprovação da Declaração de Salamanca, uma análise dos programas educacionais de melhoria da qualidade de nossa educação apresenta muitos déficits que vem obstruindo o avanço da Educação Inclusiva na realidade das escolas públicas. Carvalho (2010) destaca que a simples matrícula escolar não garante ao aluno sua permanência e a terminalidade com qualidade.

Em relação à inclusão de alunos surdos, reconhece-se que o ambiente escolar da chamada escola regular ainda precisa avançar no sentido de oferecer uma escolarização efetiva para esses alunos: professores não conseguem se comunicar com o aluno surdo; a Libras ainda não é utilizada como segunda língua etc.

A seguir serão apresentadas as análises realizadas com uma amostra de professores que participaram dos cursos de formação continuada da Plataforma Freire, na área da Educação Especial/Inclusiva, buscando desvelar alguns limites e possibilidades encontrados na dinâmica do trabalho docente, em relação à educação de alunos surdos nas escolas públicas brasileiras.

De acordo com as informações coletadas a partir do questionário aplicado aos professores cursistas, os dados do Gráfico 1 mostram que mais da metade dos professores possuem graduação e um considerável percentual (44\%) possui formação em nível de especialização latu sensu.

Gráfico 1: Formação acadêmica dos participantes do curso Atendimento Educacional Especializado para Alunos Surdos, 1a Edição - Turma 1.

\section{Formação Acadêmica}

Especialização Eraduação Ensino Médio

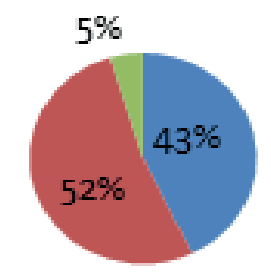

Fonte: Banco de dados do CEPAE 
Outro dado apresentado refere-se à formação continuada. Os dados mostram que $81 \%$ dos professores afirmaram que já participaram de cursos de formação continuada (Ver Gráfico 2). Entretanto, não foi solicitada no questionário a periodicidade dessa formação e o enfoque desses cursos.

Gráfico 2: Participação em Cursos de Formação Continuada dos participantes do curso Atendimento Educacional Especializado para Alunos Surdos, 1ํㅗ Edição - Turma 1.

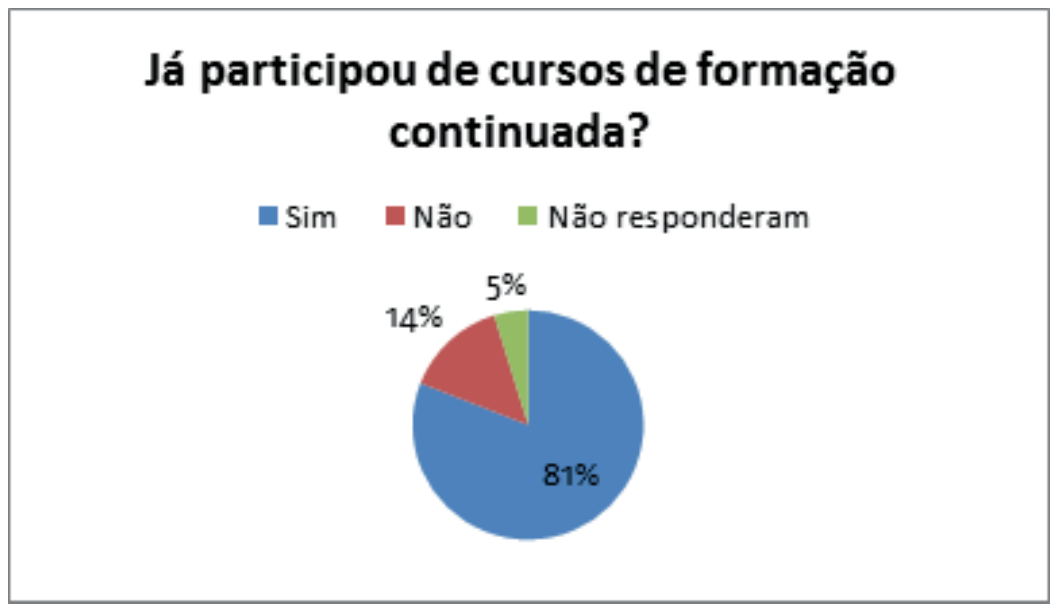

Fonte: Banco de dados do CEPAE

Em relação ao processo de formação de professores, muitas críticas têm sido realizadas aos "pacotes" de formação continuada oferecidos aos professores em exercício. Esses "pacotes" muitas vezes acontecem em momentos esporádicos e de forma padronizada, priorizando os aspectos técnicos, como se a inclusão fosse resolvida com "receitas" que podem ser aplicadas em qualquer escola e para qualquer público.

Uma formação docente nessa direção pode cair no equívoco de limitar-se a uma concepção tecnicista, de simples transposição dos saberes e fazeres da Educação Especial para a Educação Regular.

Considerando a realidade das escolas dos professores cursistas e o Atendimento Educacional Especializado, os dados apontam que 43\% das escolas não possui AEE, e uma margem ainda restrita (36\%) oferece Atendimento Educacional Especializado (AEE). Considerando que $21 \%$ não responderam o questionário, esse índice pode ser ainda maior. 
Gráfico 3: Quantitativo de escolas que possuem AEE dos participantes do curso Atendimento Educacional Especializado para Alunos Surdos, 1aㅡ Edição - Turma 1.

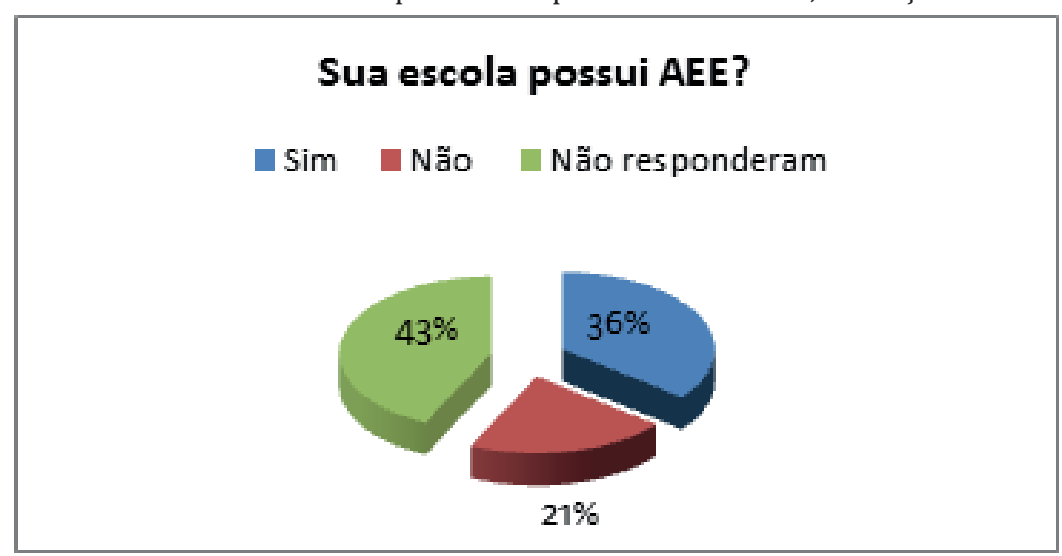

Fonte: Banco de dados do CEPAE

Tal dado merece atenção, uma vez que o oferecimento do AEE é uma exigência para toda escola pública. Como já foi dito, a implantação do AEE, como exigência legal em decorrência da Política Nacional de Educação Especial na Perspectiva da Educação Inclusiva e do Decreto n. ${ }^{\circ}$ 6.571, de 17 de setembro de 2008, revogado pelo Decreto n. - 7.611, de 17 de novembro de 2011.

O Decreto $n . \underline{0} 7.611 / 11$ determina que

Art. $1^{\circ} 0$ dever do Estado com a educação das pessoas público-alvo da educação especial será efetivado de acordo com as seguintes diretrizes:

I - garantia de um sistema educacional inclusivo em todos os níveis, sem discriminação e com base na igualdade de oportunidades;

II - aprendizado ao longo de toda a vida;

III - não exclusão do sistema educacional geral sob alegação de deficiência;

IV - garantia de ensino fundamental gratuito e compulsório, asseguradas adaptações razoáveis de acordo com as necessidades individuais;

V - oferta de apoio necessário, no âmbito do sistema educacional geral, com vistas a facilitar sua efetiva educação;

VI - adoção de medidas de apoio individualizadas e efetivas, em ambientes que maximizem o desenvolvimento acadêmico e social, de acordo com a meta de inclusão plena;

VII - oferta de educação especial preferencialmente na rede regular de ensino; e 
VIII - apoio técnico e financeiro pelo Poder Público às instituições privadas sem fins lucrativos, especializadas e com atuação exclusiva em educação especial.

$\S 1^{\circ}$ Para fins deste Decreto, considera-se público-alvo da educação especial as pessoas com deficiência, com transtornos globais do desenvolvimento e com altas habilidades ou superdotação.

$\S 2^{\circ}$ No caso dos estudantes surdos e com deficiência auditiva serão observadas as diretrizes e princípios dispostos no Decreto $n^{\circ} 5.626$, de 22 de dezembro de 2005.

Art. $2^{\circ}$ A educação especial deve garantir os serviços de apoio especializado voltado a eliminar as barreiras que possam obstruir o processo de escolarização de estudantes com deficiência, transtornos globais do desenvolvimento e altas habilidades ou superdotação.

$\S 1^{2}$ Para fins deste Decreto, os serviços de que trata o caput serão denominados atendimento educacional especializado, compreendido como o conjunto de atividades, recursos de acessibilidade e pedagógicos organizados institucional e continuamente, prestado das seguintes formas: I - complementar à formação dos estudantes com deficiência, transtornos globais do desenvolvimento, como apoio permanente e limitado no tempo e na frequência dos estudantes às salas de recursos multifuncionais; ou II - suplementar à formação de estudantes com altas habilidades ou superdotação.

$\S 2^{\circ} \mathrm{O}$ atendimento educacional especializado deve integrar a proposta pedagógica da escola, envolver a participação da família para garantir pleno acesso e participação dos estudantes, atender às necessidades específicas das pessoas público-alvo da educação especial, e ser realizado em articulação com as demais políticas públicas.

Para o cumprimento desse decreto cabe ao Poder Público efetivar ações para que a implantação do AEE seja realidade nas escolas públicas.

Mesmo sendo assegurado pelo Decreto n.o $6571 / 2008$, verifica-se que o AEE ainda não está implementado em todas as escolas brasileiras. Por ser uma ação recente, merece acompanhamento da sociedade civil para que esse direito seja respeitado. No entanto, é preciso destacar que a simples implantação do AEE não garante a aprendizagem dos alunos. Outras ações precisam ser desenvolvidas juntamente ao AEE, mudanças substanciais no interior da escola e nos sistemas de ensino.

O AEE não pode ser uma ação isolada no contexto escolar. Ele precisa fazer parte de um conjunto de ações integradas que perpassam necessariamente pelo Projeto Político-Pedagógico - PPP da escola. 
A análise dos dados da pesquisa evidencia que o AEE ainda não faz parte do Projeto Político-Pedagógico da escola.

A análise evidenciou que 31\% dos Projetos Político-Pedagógicos das escolas não mencionam a presença do AEE.

Gráfico 4: Demonstrativo de quantitativo de escolas representadas pelos participantes do curso Atendimento Educacional Especializado para Alunos Surdos, 1르 Edição - Turma 1, que possuem no PPP da Escola menção sobre o AEE.

\section{O PPP da escola menciona a presença do AEE?}

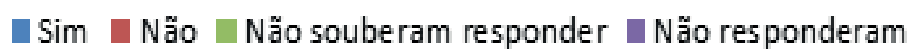

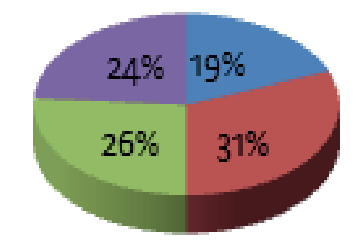

Fonte: Banco de dados do CEPAE

O PPP representa um documento importante na dinâmica escolar, como uma ação de tomada de consciência da escola (VEIGA, 2002). Essa dinâmica define as ações educativas e representa o compromisso sóciopolítico da escola. Nesse processo de tomada de consciência, a inclusão escolar e o AEE precisam ser contemplados. Um Projeto PolíticoPedagógico que não contemple os pressupostos de uma Educação Inclusiva torna-se um grande entrave para a efetivação de práticas pedagógicas inclusivas.

Para Mantoan (2003), é o Projeto Político-Pedagógico que vai definir a formação de turmas; as práticas de ensino e a avaliação serão revistas e reestruturadas, de acordo com as diretrizes da Educação Inclusiva.

Os dados mostram ainda que apenas $24 \%$ das escolas apresentam um PPP que trata da questão do AEE, em contrapartida $76 \%$ dos professores afirmam que as escolas desenvolvem práticas pedagógicas inclusivas (Ver Gráfico 5). Assim, pode-se questionar a efetivação dessas práticas ditas "inclusivas", considerando que a inclusão escolar exige um 
redimensionamento do Projeto Político-Pedagógico da instituição escolar. É somente por meio do PPP que as discussões a respeito da inclusão podem ser assumidas como um compromisso sócio-político de toda a comunidade escolar e não apenas dos profissionais que atuam no AEE.

Gráfico 5 - Demonstrativo da presença de prática inclusiva nas escolas representadas pelos participantes do Curso Atendimento Educacional Especializados para Alunos Surdos, 1a Edição - Turma 1

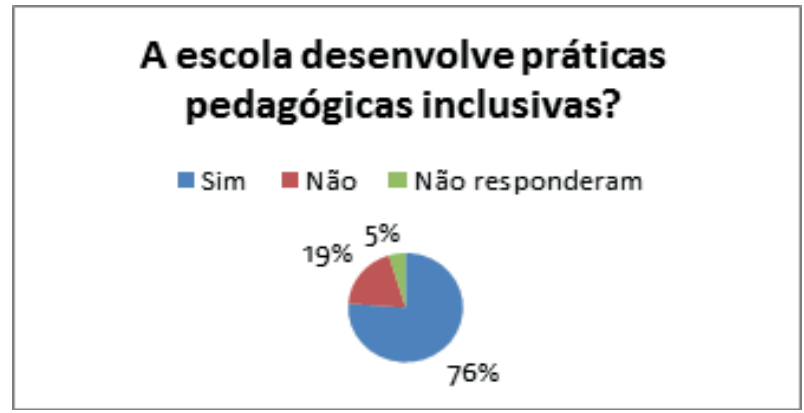

Fonte: Banco de dados do CEPAE

Em relação aos alunos surdos das escolas dos professores pesquisados, verifica-se uma porcentagem significativa (48\%) de matrícula de alunos surdos nas escolas regulares.

Gráfico 6: Demonstrativo da presença de estudantes surdos nas escolas representadas pelos participantes do Curso Atendimento Educacional Especializado para Alunos Surdos, 1르 Edição - Turma 1.

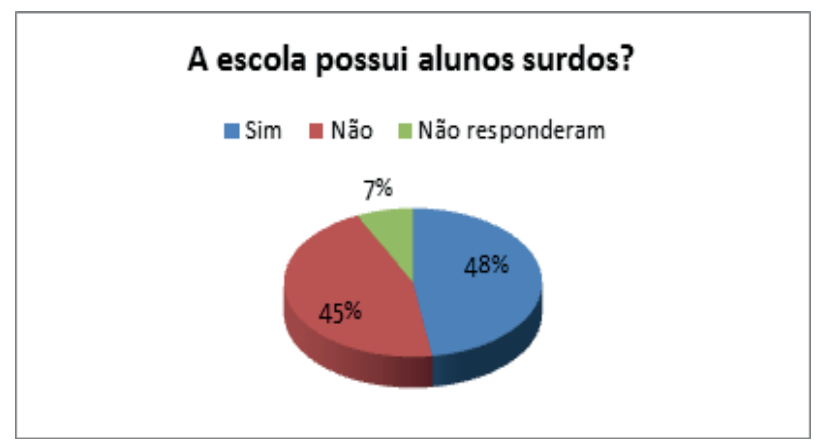

Fonte: Banco de dados do CEPAE

Confrontando esse dado com os informados anteriormente, merece atenção investigar quais são essas práticas pedagógicas inclusivas (76\%) oferecidas aos alunos surdos. 
Os depoimentos de muitos professores, mais uma vez, evidencia uma contradição. Quando foram solicitados para darem opinião sobre o processo de escolarização de pessoas surdas nas escolas em que atuam, responderam da seguinte forma:

É um processo conflituoso porque h á muitas lacunas e falhas nas escolas inclusivas, inclusive a falta de professores que saibam se comunicar com o aluno surdo. Os mesmos são obrigados a ter acesso a conteúdos em uma língua portuguesa e são avaliados através da mesma (P3 - Turma 43 Questionário).

Muito ainda precisa avançar para que o surdo seja visto não como deficiente e sim alguém com uma forma de comunicação diferente dos demais educandos. A Libras precisa estar no dia a dia das escolas, precisamos de formação continuada para educadores e valorizar os recursos visuais em sala de aula (P2 - Turma 42 - Questionário).

0 processo de escolarização de pessoas surdas não está sendo positivo. As pessoas surdas fazem um grande esforço para poder estar participando efetivamente do seu crescimento, mais vários fatores como podemos ver no decorrer do curso impedem este crescimento. Penso que a escola deveria dar mais valor a Libras (P6 - Turma 42 - Questionário).

Os depoimentos apresentam uma grande contradição, pois esses mesmos professores $(76 \%)$ afirmaram que as escolas realizam práticas pedagógicas inclusivas. Entretanto, seus depoimentos mostram que os alunos surdos não têm encontrado uma escola tão inclusiva assim. Os professores não conseguem se comunicar com o aluno surdo, uma vez que a Libras não é considerada como a $1{ }^{\mathrm{a}}$ língua do aluno surdo e a Língua Portuguesa é imposta a ele. Essa desconsideração da Libras impede uma comunicação e interação melhor entre professor e aluno, gerando, muitas vezes, o fracasso escolar dos surdos na escola regular.

Assim, embora muitos estudiosos da área da surdez defendam que o bilinguismo como uma proposta educacional para os alunos surdos, os depoimentos mostram que sala de aula regular de ensino o bilinguismo ainda não predomina.

0 processo de aprendizagem do aluno surdo, não é fácil, pois requer todo um cuidado frente ao ensino. Deve-se ter instrutor em Libras, uma interprete e currículo adaptado. Claro que sabemos que isto em muitos lugares não ocorre. Então, se deve ter uma adaptação curricular e curso 
de Libras para professores, comunidade e família, sempre levando em conta a Libras, pois é ela que dá o suporte para a segunda língua, a Língua Portuguesa (P3 - Turma 44 - Questionário).

A enturmação dos alunos é feita em turmas de ouvintes. Os professores das disciplinas são interpretados por professores interpretes. Há pouca formação por parte dos professores ouvintes fazendo com que os professores interpretes se desdobrem para interpretarem suas aulas (P7 - Turma 44 - Questionário).

Utiliza-se a comunicação oral pelos professores e em alguns momentos um aluno ouvinte que sabe Libras traduz para os alunos surdos (P1 - Turma 44 - Questionário).

A imposição da Língua Portuguesa como primeira língua associa-se a outras dificuldades encontradas na educação de surdos como a escassez de profissionais com domínio da Língua de Sinais.

Além disso, muitas vezes, o aluno surdo é introduzido em salas de aulas numerosas e com professores despreparados. Esse contexto é, muitas vezes, ignorado pelo Poder Público e a consequência desse descaso recai sobre o aluno surdo que se vê em um ambiente de abandono.

Os depoimentos dos professores participantes da pesquisa evidenciam que nas escolas que se dizem "inclusivas" presencia-se uma situação em que o surdo não vê nem sua língua nem sua cultura reconhecidas. Assim, pode-se afirmar que não basta a existência de leis que determinam a inclusão de um aluno surdo em uma escola regular. A simples matrícula não é suficiente, é preciso ações efetivas tanto no interior da escola, como no contexto macro, por meio de políticas educacionais que garantam as reais condições para que a inclusão seja uma realidade. 0 que tem acontecido nas escolas é uma "pseudoinclusão" que mascara a exclusão sutil que acomete os alunos surdos no espaço da escola regular. Se a escola regular não estiver preparada para receber o aluno surdo, respeitando suas diferenças linguística e cultural, colocá-lo nesse ambiente é a mais dolorosa forma de exclusão.

\section{Considerações finais}

A discussão realizada permite inferir que a história escolar de pessoas surdas é composta por muitas experiências educacionais restritas e excludentes. Mesmo sendo reconhecido o bilinguismo como uma abordagem que pode diminuir os percalços enfrentados pelos alunos 
surdos em seu processo de escolarização, as escolas públicas ainda persistem na comunicação oral e na imposição da Língua Portuguesa como primeira língua dos alunos surdos.

Os depoimentos dos professores mostraram que na realidade das escolas a matrícula do aluno surdo é efetivada sem garantir as condições de aprendizagem e de desenvolvimento ideais. Associado a isso os dados evidenciaram que muitas escolas ainda não oferecem o Atendimento Educacional Especializado (AEE), mesmo sendo uma exigência legal para toda escola pública.

Esse cenário impõe ao trabalho docente um leque de desafios que precisam ser considerados para que a inclusão escolar possa ser realidade na escola pública brasileira. Tal processo abrange tanto ações micros como, por exemplo, a reestruturação do PPP da escola e a garantia de práticas pedagógicas inclusivas, como ações no sentido macro, como o compromisso político do Poder Público, para garantir as condições estruturais para isso. 


\section{Referências}

BRASIL. Programa de Formação Continuada de Professores na Educação Especial. Ministério da Educação/Secretaria de Educação Especial - MEC/ SEESP: Brasília, EDITAL n.ํㅜ 02, 2007.

MEC. SEESP. Política Nacional de Educação Especial na Perspectiva da Educação Inclusiva. Brasília, DF, MEC, 2008.

Referenciais para a Formação de Professores. MEC/ Secretaria de Educação Fundamental. Brasília. A Secretaria, 1999. . Constituição da República Federativa do Brasil. Rio de Janeiro: FAE, 1988.

. LDB: Lei de Diretrizes e Bases da Educação Nacional: Lei no 9394 de 20 de dezembro de 1996 - estabelece as diretrizes e bases da educação nacional. Diário Oficial da União. Brasília, DF, 1996.

. Ministério da Educação. Política de Nacional de Educação Especial na Perspectiva de Educação Inclusiva. Brasília, DF, MEC/SEESP, 2008.

.Ministério da Educação. Diretrizes Nacionais para a Educação Especial na Educação Básica. Resolução CNE/CEB nº. 02 de 11 de setembro de 2001. Secretaria de Educação Especial - MEC / SEESP, 2001.

Decreto $n . \underline{0}$ 6.571. Dispõe sobre o atendimento educacional especializado, regulamenta o parágrafo único do art. 60 da Lei no 9.394, de 20 de dezembro de 1996, e acrescenta dispositivo ao Decreto no 6.253, de 13 de novembro de 2007. Brasília, MEC, 2008.

Decreto n. ${ }^{\circ}$ 5626/05 de 22 de dezembro de 2005. Regulamenta a Lei n.으 10436, de 24 de abril de 2002, que dispõe sobre a Língua Brasileira de Sinais - Líbras, e o Artigo 18 da Lei n.ํㅜ 10.098, de 19 de dezembro de 2000. Brasília: SEESP/MEC, 2005.

CARVALHO, R E. Educação Inclusiva: com os pingos nos “is”. Porto Alegre: Mediação, 2004.

Dez anos depois da Declaração de Salamanca. Disponível em: http://cape. edunet.sp. gov.br/textos/eventos/2.doc. Acesso em: 20 out. 2010.

FREITAS, S N et. al. Política Nacional de Educação Especial na Perspectiva da Educação Inclusiva. Inclusão: Revista da Educação Especial, Ministério da Educação, Secretaria de Educação Especial, Brasília, v.4, n.l, p. 18-32, jan/jun, 2008.

GOLDFELD, M. A criança Surda: Linguagem e Cognição numa perspectiva sóciointeracionista. São Paulo: Plexus, 2001.

MANTOAN, M T E. Inclusão escolar: o que é ? Por quê? Como fazer? São Paulo: Ed. Moderna, 2003.

Compreendendo a deficiência mental: novos caminhos educacionais. São Paulo: Scipione, 1998. 
MANTOAN, M T E. Integração x Inclusão: Escola (de qualidade) para Todos. Pátio revista pedagógica, ano 2, n. 5, maio/julho, p. 48 -51, 1998. Disponível em http:// styx.nied.unicamp. br:8080/todosnos/acessibilidade/textos/revistas/IntegInclusaoEscolaParaTodos.rtf/view. Acesso em: 20 mar. 2011.

Políticas e marcos legais para a educação inclusiva: construir a escola das diferenças - caminhando nas pistas da inclusão. Escola de atenção às diferenças. Ministério da Educação. Secretaria de Educação a Distância. Ano 20, Boletim no 03, 2010. Disponível em: http://tvbrasil.org.br/fotos/salto/series/19131803Escoladiferencas.pdf. Acesso em: 20 mar. 2010.MENDES, E G. A radicalização do debate sobre inclusão escolar no Brasil. Revista Brasileira de Educação. v. 11, n.o 33, set./dez. 2006.

SKLIAR. C B. A formação de professores ( surdos e ouvintes), desce a prospectiva da diferença. In: ENCONTRO NACIONAL DE PROFESSORES DE DIDÁTICA E PRÁTICA DE ENSINO. Rio de Janeiro, Anais do ENCONTRO NACIONAL DE PROFESSORES DE DIDÁTICA E PRÁTICA DE ENSINO. Rio de Janeiro: UERJ, 2000.

UNESCO. Coordenadoria Nacional para a Integração da Pessoa Portadora de Deficiência (CORDE). Declaração de Salamanca: princípios, política e prática para as necessidades educativas especiais. Brasília: CORDE, 1994.

VYGOTSKI, L. S. Obras Escogidas V - Fundamentos de defectología. Madrid: Visor Dis., 1997. 


\section{CAPÍTULO V}

AS VARIÁVEIS - ESTRUTURA, DIÁLOGO E AUTONOMIA -
NA RELAÇÃO DIDÁTICO-PEDAGÓGICA DE CURSO
ON-LINE: OTIMIZANDO A FORMAÇÃO E
POTENCIALIZANDO A DISTÂNCIA TRANSACIONAL

Eleodora S. Leonardi ${ }^{1}$

Eliamar Godoi ${ }^{2}$

Wender Faleiro ${ }^{3}$

A educação de qualidade é um direito de todos, portanto, sob a perspectiva da inclusão, há a necessidade de se investir na formação de professores para que atendam essa nova realidade. No que se refere à educação das pessoas surdas, é preciso que os professores compreendam as peculiaridades desta demanda e aprendam a se comunicar em Língua de Sinais e, principalmente, que nos cursos de formação sejam consideradas essas necessidades para que o processo de ensino e aprendizagem seja compreendido e desenvolvido qualitativamente.

Compreendendo a importância de se conceberem medidas capazes de avançar na inclusão de pessoas surdas no âmbito escolar, as instituições públicas brasileiras de nível superior têm desenvolvido pesquisas e práticas educacionais, levando em consideração a legislação vigente, em especial, em concordância com o Decreto n.․ 5.526, de 22 de dezembro de 2005, o qual determinou que o aluno surdo fosse educado em sua

\footnotetext{
${ }^{1}$ Mestre em Educação pela Universidade Federal de Santa Maria/RS (UFSM). Licenciada em Pedagogia Anos Iniciais e com Habilitação em Educação Infantil. Professora da Rede Particular de Ensino de Uberlândia/ Coordenadora PedagógicaECI/Uberlândia- MG. Pesquisadora do Grupo de Estudos e Pesquisas Políticas e Práticas em Educação Especial - GEPEPES. Pesquisadora no Programa de Formação Continuada de Professores CEPAE/UFU. E-mail: lelaleonardi@yahoo.com.br

2 Doutoranda do Curso de Pós-graduação em Estudos Linguísticos - PPGEL, Pesquisadora do Grupo de Estudos e Pesquisas Políticas e Práticas em Educação Especial - GEPEPES e professora da Faculdade de Educação da Universidade Federal de Uberlândia FACED/UFU. Pesquisadora no Programa de Formação Continuada de Professores CEPAE/UFU. eliamar@cepae.ufu.br

${ }^{3}$ Doutorando em Educação pela Universidade Federal de Uberlândia. Licenciado e Bacharel em Ciências Biológicas, graduando em Pedagogia, mestre em Ecologia. Coordenador e docente do Curso de Ciências Biológicas da Universidade Presidente Antônio Carlos, campus Araguari. Pesquisador do Grupo de Estudos e Pesquisas Políticas e Práticas em Educação Especial - GEPEPES. Pesquisador no Programa de Formação Continuada de Professores CEPAE/UFU wender.faleiro@gmail.com
} 
língua natural. Esse contexto de atendimento ao aluno surdo em sua língua materna provocou intensa demanda por profissionais capacitados a atenderem os alunos surdos em suas especificidades e em diferentes níveis de ensino.

A escassez de profissionais qualificados para atuarem nas salas de recursos multifuncionais, aliado à carência de formação teórica e prática para realização do trabalho pedagógico necessário ao atendimento do aluno surdo na rede pública de ensino levou à criação e oferta do curso de Atendimento Educacional Especializado para Alunos Surdos.

Nessa perspectiva, o governo tem fomentado a oferta de inúmeros cursos de formação continuada em ambiente on-line a fim de suprir as carências de formação inicial e continuada dos profissionais que atuam no Atendimento Educacional Especializado - AEE em todo o país. O Centro de Ensino, Pesquisa e Extensão em Atendimento em Educação Especial $\mathrm{CEPAE}^{4}$, da Universidade Federal de Uberlândia - UFU, firmou parceria com a rede de formação continuada a distância de professores em Educação Especial do Ministério da Educação - MEC, e com a Secretaria de Educação Especial - SEESP ${ }^{5}$, juntamente com a Universidade Aberta do Brasil $\mathrm{UAB}^{6}$, para oferecer o Curso Atendimento Educacional Especializado para Alunos Surdos.

Logo, a partir de 2010, entre outras iniciativas, o curso de aperfeiçoamento denominado Curso de Atendimento Educacional Especializado para Alunos Surdos foi ofertado pela referida universidade na modalidade de Educação a Distância on-line, cujo objetivo principal foi capacitar cerca de 3000 professores da rede regular de ensino público brasileiro em três edições, proporcionando a formação continuada para professores que atendem e/ou almejam dar atendimento aos alunos surdos da rede regular de ensino.

Por conseguinte, para favorecer a formação dos cursistas na modalidade de educação a distância, a relação professor-aluno se faz muito importante. Entretanto, essa relação carece de uma mediação eficiente que conduza do processo didático-pedagógico de modo que todos os alunos possam ter acesso às informações e atividades de modo rápido e

${ }^{4}$ Maiores informações sobre o Centro de Ensino, Pesquisa e Extensão em Atendimento em Educação Especial - CEPAE disponíveis em: <http://www.cepae. prograd.ufu.br/>.

${ }^{5}$ Desde 2011, a Secretaria de Educação Especial se transformou na Diretoria de Políticas Pedagógicas de Educação Especial, da Secretaria de Educação Continuada, Alfabetização, Diversidade e Inclusão - SECADI.

${ }^{6}$ Maiores informações sobre a Universidade Aberta do Brasil disponíveis em:< http://uab.pti.org.br/> 
prático. Nesse aspecto, o professor formador exerce função primordial na orientação e no acompanhamento de todo o trabalho do tutor. Essa tríade professor formador-tutor-cursista compreende uma importante ferramenta para otimizar esse processo de ensino e aprendizagem.

A relação didático-pedagógica entre professor formador e tutor é responsável por criar condições favoráveis à aprendizagem, à compreensão e ao desenvolvimento da autonomia do cursista, compondo assim uma importante dinâmica para que essa formação tenha resultados satisfatórios na prática educativa. Nesse contexto, por meio de uma pesquisa de natureza qualitativa, a coleta de dados se pautará nos registros das interações ocorridas entre professor formador e seus respectivos tutores.

Para vislumbrar as implicações dessa relação no desempenho do aluno, optamos selecionar, de modo aleatório, e analisar alguns registros de interação tutor-aluno postados no Ambiente Virtual de Aprendizagem - AVA. As análises se pautaram no viés da Teoria da Distância Transacional proposto por Moore (1993) que considera a distância entre os agentes de um curso a distância sob uma perspectiva pedagógica.

Esse autor lança um olhar sobre as relações, considerando as características pessoais dos agentes envolvidos, dos temas e objetivos propostos, além dos meios e ferramentas disponíveis, combinando pressupostos da seleção de técnicas e estratégias com as dimensões: estrutura, diálogo e autonomia. Sendo assim, definimos como sujeitos de nossa pesquisa quatro professores formadores, seus respectivos tutores (nove) e alunos. Lembrando que as análises se pautaram em eventos de interação postados na Plataforma Moodle do curso.

Portanto, um curso de aperfeiçoamento como o ofertado pelo Centro de Ensino, Pesquisa e Extensão em Atendimento em Educação Especial CEPAE/UFU viabiliza a formação continuada dos professores da rede pública de ensino, favorecendo as condições de atendimento a todos aqueles que demandam um Atendimento Educacional Especializado, a fim de garantir a qualidade em educação e a eficácia do processo de inclusão escolar.

\section{Educação a Distância: conceitos, textos e contextos}

O contexto da Educação a Distância tem gerado iniciativas de diversas áreas do mercado de trabalho, inclusive das áreas acadêmicas. Atualmente, diversos setores e, até mesmo, o governamental, têm dispensado investimentos na busca pela qualidade do ensino e da formação profissional, objetivando suprir a demanda por profissionalização, 
formação e capacitação exigidas pelo mercado de trabalho. Entretanto, a busca, neste momento, é para desenvolver qualidade em docência e em aprendizagem no sentido de acompanhar as exigências específicas para uma formação de qualidade via ambiente virtual.

0 contexto do ambiente virtual de educação permite a postagem de cursos que podem ser acessados e desenvolvidos à distância, mas também permite o acompanhamento das ações dos elementos e agentes envolvidos no processo de ensino e aprendizagem no curso. Dessa forma, esse ambiente virtual apresentado traz a ideia da educação online (Moran, 2003). Trata-se de um mecanismo que apresenta a internet como o único meio para que o conteúdo do curso seja acessado, e possui como principais características, justamente, o que prevê as tecnologias da Educação a Distância.

Nesse caso, a educação-formação oferecida via ambiente on-line permite velocidade nas trocas de informações, acesso às informações de modo síncrono e assíncrono, a possibilidade de acompanhamento do desenvolvimento do aluno a distância e certo grau de interatividade entre alunos, professores e equipamentos.

Sendo assim, a Educação a Distância entra em cena para auxiliar a resolver os problemas da educação superior brasileira e de capacitação profissional. Segundo Behar; Passerino; Bernardi (2007, p. 2)

Com o uso de ferramentas tecnológicas para a geração do ensino remoto, governo, entidades públicas e privadas esperam romper o gigantesco déficit educacional e encontrar o caminho da inclusão digital na Sociedade da Informação. Logo, vê-se que esta modalidade tem instrumentos capazes de transformar a educação brasileira, com o uso das tecnologias de informação e comunicação (TIC). Acredita-se que, sem o uso intensivo de tecnologia, as universidades brasileiras não terão condições de atingir todo o seu leque de formação/capacitação na educação superior.

No entanto, atualmente, a Educação a Distância tem na modalidade on-line uma nova dimensão com novas possibilidades e novos desafios nos levando a pensar e arquitetar novas formas de ensinar e de aprender. É nessa perspectiva que a Educação a Distância disponibilizada em ambientes virtuais educacionais permite o acesso ao ensino superior, amenizando o déficit educacional, colocando a educação superior ao alcance das pessoas que não tiveram oportunidade de ingresso.

Dessa forma, a Educação a Distância na modalidade on-line surge com a grande responsabilidade de suprir o déficit e ampliar o acesso ao ensino 
superior e a cursos de capacitação, propiciando a formação continuada. Mesmo assim, embora represente uma modalidade nova, que ainda se encontra em busca de formalização de bases teóricas e epistemológicas, essa modalidade educacional veio para complementar e não substituir o ensino convencional, abrindo possibilidade de evolução para essa geração de ensino, mas ainda requer conceituação e muita pesquisa.

Segundo Behar; Passerino; Bernardi (2007, p. 3), a Secretaria de Educação a Distância tem incentivado

pesquisa e o desenvolvimento, voltados para a construção de novos conceitos e práticas nas instituições públicas brasileiras, desenvolvendo vários programas e projetos. Entretanto, para que isto realmente venha a ser uma das saídas, há necessidade de se construir um modelo consistente, com pilares bem estruturados, no que se refere aos seus aspectos epistemológicos, pedagógicos, organizacionais, tecnológicos e metodológicos.

Como a área de Educação a Distância ainda está em busca da formalização de uma base teórica, devemos esclarecer que na expressão 'Educação a Distância' - EAD o termo Educação normalmente é substituído por Ensino, embora muitos estudiosos prefiram o primeiro termo, já que remete ao um conceito mais amplo que o de Ensino. Em nosso trabalho, nos permitimos adotar o termo Educação, já que atuamos num campo mais geral de pesquisa que é investigar como ocorre a relação entre professores formadores e tutores que atuam na oferta de um curso de capacitação e as implicações dessas relações no desempenho do aluno cursista. Nosso estudo prevê um acompanhamento do processo ensino-aprendizagem de um curso a distância ofertado em contexto on-line.

Em relação ao conceito, segundo Maia e Mattar (2007, p. 06) “[...] a Educação a Distância é uma modalidade de educação em que professores e alunos estão separados, é planejada por instituições e utiliza diversas tecnologias de comunicação". A partir desse conceito, podemos perceber que a modalidade a distância se configura como um processo relevante para o desenvolvimento da educação que passa a usar das novas tecnologias para se configurar como evolução no que se refere ao ensino sistematizado. Essa modalidade tem-se atualizado no decorrer dos tempos e agregado muita pesquisa e uso de tecnologias. Ao obter ampla aceitação, a Educação a Distância requer estratégias diferenciadas para sua prática.

Nesse contexto teórico, para desenvolver esse trabalho, adotamos o conceito de Educação a Distância como um meio que possibilita 
à comunicação, o ensino, a aprendizagem, o desenvolvimento de competências, habilidades e construção de conhecimento. Percebemo-la como um processo de socialização cujas ferramentas se configuram como dispositivos motivadores e como instrumentos pedagógicos dinâmicos que desencadeiam novas formas de pensar, construir conhecimento, novos modos de ensinar e de aprender amparados pela interação.

Assim, concebendo a linguagem como um lugar de ação e interação, buscamos uma ampliação do conceito de interação em que o diálogo ocorre de forma dialógica, influenciando na experiência do dia a dia em campos de prática de ensino e de aprendizado o qual, no ambiente on-line, tende a ocorrer por meio da prática, ou seja, pelo aprendizado significativo.

Como já vimos, o contexto da Educação a Distância prevê situações bem distintas das práticas de ensino convencional, pois tende a promover uma separação de questão espacial e temporal entre professor e aluno, requerendo um planejamento adequado à modalidade a distância, além de usar as novas tecnologias de comunicação. Outro fator que favorece as práticas de ensino e aprendizado é que essa modalidade, oferecida por meio das mídias interativas, contribui para que o aluno construa o seu conhecimento de forma autônoma e significativa, respeitando o tempo de desenvolvimento de cada um. Nesse aspecto, é notória a evolução do ensino por meio dessa modalidade e mudanças se fazem indispensáveis.

Segundo Maia e Mattar (2007, p. 08),

o que mudou com as novas mídias é que os alunos e professores têm a possibilidade de interação e não apenas de recepção de conteúdos. Além disso, o aluno e o professor on-line aprendem a trabalhar com essas ferramentas.

Nesse contexto, esses autores chamam a atenção para uma proposta que valoriza um aprendizado significativo tanto para o professor em sua busca por capacitação profissional quanto para o aluno que aprende fazendo.

Tudo isso num processo interativo que supera a barreira do espaço e do tempo, favorecendo ao dialogismo e distribuindo responsabilidades. Nesse caso, o aluno deve assumir responsabilidade pelo seu aprendizado e o professor assumir o papel de mediador do conhecimento, além de criador de ambientes de aprendizado. Apostaremos, entretanto, numa "apropriação" das tecnologias para que tanto o ensino quanto o aprendizado obtenha êxito, evolução e desenvolvimento, em um processo de busca e construção do conhecimento por meio da interação. 
No que se refere à apropriação das novas tecnologias como forma emancipatória, temos Pellanda, Schlünzen e Schlünzen Júnior (2005) que veem a inclusão digital e a cultura das novas tecnologias como modelos potencializadores das qualidades dos seres humanos na busca pela autonomia na construção do aprendizado.

Segundo esses autores, a implantação do Ensino a Distância depende de fatores que vão além da apropriação de tecnologias. Para eles, são necessários investimentos mais direcionados e acertados principalmente na capacitação de muitos professores que ainda se veem às margens do uso das tecnologias. Assim, não basta o envio de máquinas 'potentes' para as escolas que sequer possuem locais adequados para recebê-las, mas carece estruturar, 'treinar', moldar a cultura tradicional, integrar e, principalmente, incluir o uso das mídias no contexto escolar, amenizando a atual situação de exclusão digital.

Os autores acima, ainda esclarecem que a

exclusão digital não afeta somente os mais carentes do ponto de vista socioeconômico, mas os trabalhadores das empresas, os indivíduos com necessidades especiais, muitos alunos e educadores que ainda não têm a oportunidade de trabalhar com esses recursos tecnológicos (Pellanda; Schlünzen e Schlünzen Jr., 2005, p. 17)

Esses autores apostam no engajamento de vários aspectos que tendem a contribuir para o desenvolvimento da educação por meio do uso de todo o potencial que as tecnologias de informação e de comunicação e que o Ensino a Distância podem oferecer para a melhoria do processo ensino e aprendizagem, favorecendo melhorias de vida para toda a sociedade. Assim, por um lado, apostam na apropriação das tecnologias como forma de promover as transformações necessárias na melhoria da qualidade de vida dessas pessoas.

Nesse contexto, percebemos que as principais dificuldades na difusão dessas novas tecnologias no ensino estão no precário nível de "inclusão digital" da nossa sociedade, mas também se encontra na necessidade de desenvolvimentos de uma nova didática, adequada a elas, bem como na sua absorção na nossa cultura de ensino.

Por outro lado, asseveram que para que essa apropriação ocorra, o acesso à tecnologia deve ser acompanhado de ações educacionais, prevendo a intencionalidade dos que ensinam ao assumir o papel de educador. Nesse contexto, ao professor é dada a função de criador de condições para que haja construção de conhecimento em relação aos aspectos técnicos 
e em relação à busca por novas didáticas e por conteúdo disciplinar que envolve os aprendizes em práticas comunitárias significativas.

Aos alunos é dada a oportunidade de buscar soluções e aplicá-las na resolução de problemas em contextos próprios. Nesse caso, não basta disponibilizar as tecnologias para que as pessoas possam utilizá-las, mas proporcionar condições para que as ações possam ser realizadas tanto do que se refere ao ensino quanto ao aprendizado. Na percepção desses autores, a visão de "inclusão digital" vai além de distribuir recursos tecnológicos e de tornar a internet disponível, isto é, eles acreditam em um contexto digital que evolui para um direcionamento de novas ações de inclusão mais profundas e efetivas do ponto de vista cognitivo, afetivo e social.

Da parte do curso analisado, observamos que as relações entre professores formadores e tutores interferiam no desempenho do aluno de modo significativo. Como o curso foi previsto para atender um número muito grande de alunos, careceu também do envolvimento de um número considerável de professores e tutores. Nesse contexto de relações múltiplas, envolvendo educação e tecnologia, decidimos analisar quais a implicações das relações entre professores e tutores no desempenho do aluno que busca por capacitação.

Em relação ao perfil dos professores formadores do curso, a equipe possui alto grau de formação e habilitados para desenvolver o trabalho de planejamento, sistematização e oferta do curso. Essa equipe é formada por professores doutores e mestres com prática em contexto do ensino mediado por tecnologias e ofertado a distância. Todos já possuem pesquisas e publicações na área e em um regime de grupo desenvolvem pesquisas sobre a educação a distância.

No que se refere ao perfil dos tutores do curso, toda a equipe de tutores tem formação superior e a maioria possui Pós-graduação. Esses perfis revelam que o acompanhamento do curso é feito por profissionais que possuem alto nível de conhecimento e certificação. Em uma relação dinâmica e produtiva, esses profissionais se relacionam com um objetivo maior que é o de promover formação e capacitação de outros profissionais que atuam, recebendo pessoas com necessidades especiais.

Recentemente, Moore (1993) apresentou como proposta, a teoria de distância transacional que visa permear o contexto da Educação a Distância e conduzir pesquisas nessa área. Essa teoria abrange todo o universo de relações entre professor e aluno, pois sua base prevê a interação como ponto de partida para compor o campo do saber nessa modalidade. Assim, além de definir 'distância transacional', Moore (1993, p. 2) esclarece que 
A transação a que denominamos Educação a Distância ocorre entre professores e alunos num ambiente que possui como característica especial a separação entre alunos e professores. Esta separação conduz a padrões especiais de comportamento de alunos e professores. A separação entre alunos e professores afeta profundamente tanto o ensino quanto a aprendizagem. Com a separação surge um espaço psicológico e comunicacional a ser transposto, um espaço de potenciais mal-entendidos entre as intervenções do instrutor e as do aluno. Este espaço psicológico e comunicacional é a distância transacional.

Para Moore (1993), há componentes fundamentais que devem ser considerados na área da pesquisa em Educação a Distância tais como: a estrutura dos programas educacionais, a interação entre alunos e professores e a natureza e o grau de autonomia do aluno. Esse conjunto de fatores compõe um universo de relações que se configura como base constitutiva primordial do processo ensino-aprendizagem no ambiente virtual. Esse autor ainda considera a distinção entre as estratégias de ensino e aprendizado da modalidade a distância e a presencial, embora perceba que mesmo presencialmente haja uma distância transacional entre professor e aluno, mas acredita que

na situação à qual normalmente nos referimos como educação a distância, a separação entre professor e aluno é suficientemente significativa para que as estratégias e técnicas especiais de ensino-aprendizagem por eles utilizadas possam ser identificadas como características distintivas desta linhagem de prática educacional. (Moore, 1993, p. 2)

Embora o autor perceba a existência de padrões reconhecíveis no ensino a distância, reconhece também que há uma enorme variação nessas estratégias e técnicas tanto no comportamento de professores quanto de alunos. Por isso, defende que há diferentes graus de distância transacional. Esse autor considera que o propósito da Teoria da Distância Transacional é resumir as diferentes relações e a intensidade delas entre duas ou mais variáveis que compõe a distância transacional especialmente a que se refere ao comportamento de professores e alunos.

Esse autor considera a extensão da distância transacional como um programa educacional que envolve não as variáveis tecnológicas ou comunicacionais como normalmente é destacado nas pesquisas atuais, mas sim, variáveis em ensino e aprendizagem, e na interação entre ensino e aprendizagem. Esses grupos de variáveis são denominados: Diálogo, Estrutura e Autonomia do Aluno. 
Para Moore (1993), não se deve suprimir a distância transacional. 0 certo seria implementá-la em dosagem adequada sempre considerando as características pessoais dos alunos, dos temas e objetivos propostos, além dos meios e ferramentas disponíveis. Por isso, esse autor esclarece que cada curso requer uma distância transacional específica que será obtida por meio da seleção de técnicas e estratégias que combinem adequadamente as três dimensões: estrutura, diálogo e autonomia.

Ainda sobre a Teoria da Distância Transacional, Leite (2006) esclarece que essa teoria colabora com o desenvolvimento tecnológico atual, e sua integração aos sistemas de aprendizagem a distância tem possibilitado o desenvolvimento de sistemas interativos de aprendizagem na modalidade a distância, superando inúmeros desafios. Essa autora considera, conforme a teoria de Rogers (1993), o papel do professor como facilitador, provocador, e instigador da aprendizagem individual e coletiva.

Assim, ao considerar a variável da autonomia do aluno, proposta por Moore (1993), ela esclarece que além da docência, para que o aluno busque e consiga essa autonomia, alguns atributos são indispensáveis. Desse modo, uma série de fatores como idade, profissão, área de interesse, objetivos dos alunos para com o curso, tudo isso influencia e permite que os alunos possam realizar um curso a distância com a autonomia prevista pela Teoria da Distância Transacional. Leite (2006), por meio de suas pesquisas, pôde constatar que alunos adultos em busca de aperfeiçoamento profissional apresentam maior probabilidade de adquirir o conhecimento com autonomia por meio dos cursos oferecidos on-line.

Tendo como principal objetivo a capacitação, os alunos que são atendidos pelo curso buscam por uma proposta pedagógica que assegure recursos e serviços educacionais especiais, organizados que apoiem e/ ou complementem o trabalho realizado ao receber pessoas especiais em seu ambiente de trabalho em contexto educacional. Muitos desses alunos se enquadram na perspectiva da busca autônoma pelo conhecimento, entretanto, o ambiente do curso deve contemplá-los em sua busca por conhecimento e por capacitação. Nesses termos, segundo Faleiro; Souza e Silva (2010), a oferta da capacitação a distância é fundamental para os professores atuarem com os alunos com necessidades educacionais especiais. Ainda de acordo como esses autores, a oferta de um curso de aperfeiçoamento, como o analisado, prevê

uma formação adequada em nível médio ou superior para desempenhar a docência no atendimento especializado, bem como no ensino regular. Prevê-se a atuação de professores capacitados para integração desses 
educandos nas classes comuns, lócus prioritário para a escolarização de todos os estudantes do País, independente da condição que possuam (Faleiro; Souza; Silva, 2010, p. 33).

De um modo geral, o perfil dos alunos que buscam o aperfeiçoamento demonstra que são profissionais interessados em se preparar para atuar positivamente nos processos de escolarização das pessoas com diferentes formas de necessidades, mas que não possuem acesso a uma instituição ou tempo fixo disponível para fazer um curso desses na modalidade presencial.

Nesse aspecto, reforça a necessidade de ofertar cursos com qualidade e com temas relevantes que contemplem a necessidade de cada cursista e, ainda, que apresente, de certa forma, uma articulação entre teoria e prática para que o conhecimento adquirido no curso possa ser aplicado em contexto de sala de aula ou de Atendimento Educacional Especializado. A oferta de um curso que proporcione formação continuada e que possa ser acessado à distância e em horários flexíveis é fundamental, para atender profissionais que não dispõem de outras opções de formação-capacitação.

Dada a relevância da formação continuada, segundo Silva (2010, p. 15), "cada sistema de ensino vem se organizando de uma forma peculiar para atender as demandas de formação continuada de seu quadro de profissionais". Essa autora também esclarece que a preocupação em ofertar cursos de formação continuada deve partir dos profissionais das instituições de ensino superior.

As instituições devem se constituir como uma referência básica para as propostas de estudo e formação. Sendo assim, os subsídios teóricos devem contemplar o movimento ação-reflexão-ação. Essa tríade das ações é capaz de promover cursos que atribuam sentidos às experiências de formação dos profissionais articuladas a suas vivências cotidianas. Esse movimento triádico leva o aluno/cursista a participar do próprio processo de aprendizagem, ressignificando o curso e promovendo mudanças em sua prática.

Enfim, com o advento das tecnologias digitais, o mercado de trabalho recebe novo formato e novos interesses no ambiente virtual. Todo esse contexto tecnológico da sociedade aliado à necessidade da formação e capacitação profissional nos leva aos cursos a distância. Esses cursos têm um papel fundamental na era tecnológica, pois garantem a formação e a capacitação para um grande número de pessoas ao mesmo tempo, atendendo-as em diferentes lugares. 
Sendo assim, o objetivo da Educação a Distância é propiciar recursos didático-pedagógicos viabilizados pelas tecnologias digitais que possibilitem uma formação de qualidade a profissionais que atuam no mercado de trabalho e na educação, e ainda suprir o vácuo deixado pelo ensino na modalidade presencial que não consegue atingir esse patamar nem atender os diversos ramos da ação educacional.

De um modo sistemático, na busca por uma teoria que contemplasse nossos questionamentos a respeito das relações que compõem o processo ensino e aprendizagem no ambiente virtual, encontramos nos princípios da Teoria da Distância Transacional uma nova alternativa de condução de nossos estudos. Haja vista o fato de que esses princípios contemplam o universo de relações entre professor e aluno, e que tem por base a interação como ponto de partida para a aprendizagem.

Sendo assim, decidimos analisar as relações entre participantes do curso de Atendimento Educacional Especializado - AEE ofertado em contexto on-line com um enfoque especial nas relações entre professores formadores e tutores do curso à luz da Teoria da Distância Transacional proposta por Moore (1993). 0 objetivo é perceber as implicações dessa relação no desempenho dos alunos e sugerir encaminhamentos para os próximos cursos.

A seguir apresentamos uma descrição detalhada do Curso de Atendimento Educacional Especializado, cenário de nossa pesquisa.

\section{Curso de Atendimento Educacional Especializado para Alunos Surdos: elementos constitutivos do ensinar e aprender}

A formação continuada e adequada para os professores da rede regular de ensino público é indispensável para atender as necessidades educacionais dos alunos surdos. Assim, para que se desenvolvam práticas educativas que acolham essa demanda é imperativo que esses professores tenham acesso aos conhecimentos teóricos e práticos imprescindíveis para o sucesso na aprendizagem desses alunos.

Nesse contexto, a realização do Curso de Aperfeiçoamento em Atendimento Educacional Especializado para Alunos Surdos, oferecido pela Universidade Federal de Uberlândia, propõe a formação continuada a distância de professores, tendo como finalidade capacitar professores da rede regular de ensino público nacional que atendam ou tenham pretensão de atender alunos surdos.

0 referido curso é gratuito, delineando um amplo compromisso social, pois além de oferecer a formação continuada colabora com 
professores de todo o Brasil em sua ascendência profissional e progressão salarial. Organizado e aplicado na modalidade on-line, o curso desenvolvese por meio de unidades temáticas que vinculam os pressupostos teóricos da área de Educação Especial e de surdos, à realidade vivenciada pelos professores cursistas.

Esse curso utiliza uma metodologia interativa, com materiais pedagógicos planejados e específicos, seminários temáticos, por meio de fóruns, chats, entre outros, que auxiliam na explanação e compreensão dos conteúdos. Tais ferramentas delineiam a proposta do curso que visa qualificar professores que fazem o Atendimento Educacional Especializado para Alunos Surdos, propiciando a construção de conhecimentos sobre a Educação Especial em uma perspectiva educacional inclusiva. Aliando teoria e prática, o curso contribui significativamente com a melhoria da qualidade de atendimento educacional, e favorece uma inclusão social ativa, participativa, autônoma e democrática para os alunos surdos.

Considerando as necessidades e o desenvolvimento dos alunos surdos e a formação dos professores, o curso tem uma carga horária de 180 (cento e oitenta) horas, divididas por uma primeira parte sobre os fundamentos da Educação Especial e as demais relativas a Língua Brasileira de Sinais tendo o Língua Portuguesa como segunda língua.

Vinculado à Plataforma Paulo Freire e realizado totalmente a distância, o curso é disponibilizado via internet, podendo ser acessado de qualquer lugar. Esse formato permite o acompanhamento do desenvolvimento do curso através do envio e compartilhamento de materiais de estudo, fóruns virtuais, chats, coleta e correção de atividades, registros, relatórios de notas, livros on-line, entre outros.

Paraque o processo de ensino eaprendizagem se efetive, o curso possui 17 (dezessete) professores formadores/pesquisadores, e 50 (cinquenta) tutores para guiar os estudos e atividades dos cursistas. 0 professor formador é o profissional responsável pela orientação, acompanhamento e observação da participação dos tutores no desenvolvimento das atividades propostas. Assim, ele deve assessorar o tutor, promover a sistematização, aprofundar os conteúdos apresentados no curso, sanar as dúvidas dos tutores e dos alunos sempre que houver necessidade.

Por sua vez, o tutor exerce uma ação mediadora, orientando e acompanhando o desenvolvimento de cada aluno, através dos recursos e ferramentas disponibilizados no Ambiente Virtual de Aprendizagem - AVA. Ele é o responsável direto pela avaliação do desempenho dos cursistas na realização das atividades.

Logo, o trabalho do professor formador e do tutor se complementa, e serve para articular e melhorar a construção dos conhecimentos dos 
professores em formação, capacitando-os. Por conseguinte, os cursistas precisam dedicar um tempo específico e diário aos estudos, participar, comprometer-se e ter um bom desempenho na realização das atividades. Portanto, a dinâmica resultante da inter-relação professor formador e tutor auxilia e favorece os cursistas durante todo o curso e após seu término. As orientações feitas por estes profissionais contribuem para o professor ser agente ativo nas práticas educativas referentes ao AEE para alunos surdos.

\section{Condução da pesquisa, coleta e análise dos dados}

Tendo em vista a ampla oferta de cursos de formação e formação continuada na modalidade a distância e em contexto on-line, e considerando os novos vieses de pesquisas sobre o processo ensino e aprendizagem que esse contexto suscita, optamos apresentar, neste trabalho, uma análise de abordagem diferenciada.

Como há muito tempo trabalhamos e pesquisamos o processo ensino e aprendizagem na Educação a Distância e em contexto on-line, também, há tempos, ansiávamos por novas alternativas de pesquisa que englobassem muitos de nossos questionamentos sobre o processo. Buscávamos por abordagens que, de algum modo, possibilitasse-nos um ponto de partida e novas alternativas para desenvolver estudos que englobassem, além do processo, maneiras ou vieses de análises das redes de relações que compõem um curso ofertado em Ambiente Virtual de Aprendizagem - AVA.

Ao vislumbrar inúmeras abordagens para coleta e análise de dados levantados no contexto do processo ensino e aprendizagem da educação mediada por computador encontramos na Teoria da Distância Transacional, proposta Moore (1993), uma nova alternativa de condução para nossas pesquisas.

Como as redes de relações da Educação a Distância pressupõem sempre um processo colaborativo tanto para o ensino quanto para o aprendizado, percebemos nessa teoria uma alternativa de observar e descrever o que emerge das relações interativas de ensino e aprendizagem colaborativas no contexto do Curso de Atendimento Educacional Especializado para Alunos Surdos, ofertado pelo Centro de Ensino, Pesquisa, Extensão e Atendimento em Educação Especial - CEPAE/UFU.

Sendo assim, nessa direção, decidimos, neste trabalho, apresentar aspectos, conceitos dessa teoria, e demonstrar que algumas das relações que compõem o curso apresentam indícios que combinam adequadamente 
as três dimensões que compõe um curso com sua distância transacional desenvolvida. Essas dimensões são: estrutura, diálogo e autonomia. Enfocamos, sobretudo, a relação entre as dimensões diálogo e autonomia, considerando que a dimensão do diálogo favorece e delineia a dimensão da autonomia.

Vislumbramos, então, qual seria o papel da distância no processo educacional do curso analisado e suas implicações na ação dos agentes envolvidos. Questionamos, assim, se as relações e interações dos professores formadores com seus tutores exercem alguma influência no desempenho do aluno, sobretudo, na motivação para permanência do curso e na autonomia na busca pela aprendizagem, e se a distância transacional entre esses agentes influencia de alguma forma essas relações.

Começamos, então, pela descrição da dimensão estrutural do curso. 0 curso de AEE é organizado de modo a suprir carências na oferta de formação continuada e de capacitação de profissionais aptos a atenderem e receberem alunos surdos na rede regular de ensino. Nesse caso, trabalha com professores e profissionais que já atuam no contexto educacional nas várias esferas, sobretudo na estadual e municipal.

Esses profissionais, público alvo do curso, possuem formação de nível de graduação ou ensino médio. 0 objetivo do curso é atender as várias regiões brasileiras, entretanto, percebemos que muitos alunos não possuem prática para acessar o computador. Nesse contexto, o curso careceu de organizar uma estrutura que favorecesse certa facilidade de acesso aos alunos; caso fosse uma plataforma com um programa muito complexo, dificultaria a acessibilidade o que poderia favorecer a evasão.

Pensando nisso, optou-se pela Plataforma Moodle e a primeira unidade do curso ofertada foi a "Introdução à Educação a Distância". A plataforma Moodle foi a escolhida pelo fato de se constituir de um espaço virtual que facilita o acesso e incentiva a busca pelo conhecimento de modo autônomo por parte do aluno. Sendo um ambiente virtual de aprendizagem, ela se constitui como um sistema gerenciador de cursos. Essa plataforma possui uma diversidade de recursos de apoio ao processo de ensino e aprendizagem a distância, e foi planejada para proporcionar ao aluno autonomia nos estudos. Nessa plataforma, o design instrucional foi especialmente pensado para facilitar a interatividade e promover a autonomia na busca pelo conhecimento.

Print screen do ambiente do curso.

Podemos perceber que o design do curso segue um modelo interativo de comunicação que utiliza mecanismos de comunicação multidirecionais (muito-para-muitos) como chats, fóruns, mas também 
utiliza mecanismos de comunicação bidirecionais (um-para-um) como o diário de bordo e os e-mails internos. Pudemos perceber que desses mecanismos de comunicação utilizados, os fóruns se destacaram como principal meio de comunicação multidirecional, funcionando como ponto de encontro para diálogos entre: professor e tutor; entre tutor e o aluno e entre os alunos entre si. Dentre os mecanismos bidirecionais do design do curso, os diários de bordo foram destaque. Essa ferramenta favoreceu ao aluno o autoacompanhamento das atividades e do seu rendimento.

$\mathrm{Na}$ relação professor-formador e tutor, a ferramenta que mais se destacou foi o fórum, principalmente o Fórum Geral de Coordenação e Tutoria. Esse espaço foi fundamental para estabelecer o diálogo entre professores e tutores. Esse diálogo recebeu a todo o momento a mediação da coordenadora de tutoria do curso que esteve presente sempre orientando e motivando a interação, e promovendo o diálogo entre todos os demais agentes do curso (professor formador, tutor e alunos). Assim, sempre que havia necessidade, esse novo elemento surgia para favorecer o processo de interação do curso. Essa participação efetiva e direcionada pode ser vislumbrada no seguinte excerto de comunicação da coordenadora para com os professores e tutores:

Coordenadora de tutoria: "Prezados professores(as) e tutores(as), Sejam todos(as) bem vindos(as) ao curso de Atendimento Educacional Especializado para Alunos Surdos - Turma III. Aproveite o espaço para trocar conhecimentos, tirar dúvidas, dialogar. Desejo a todos(as) um bom trabalho".

Nossas análises mostraram que a figura da coordenadora de tutoria foi fundamental para promover a dimensão diálogo e favorecer a aprendizagem colaborativa, pois a ideia de grupo esteve sempre presente nos registros das interações entre a coordenadora, professores e também tutores. Podemos perceber a ideia de aprendizagem e trabalho colaborativo ainda no seguinte excerto de comunicação de um professor para a coordenadora de tutoria: "Obrigada pelos desejos de bom curso... que todos em conjunto possamos realizar um trabalho de qualidade!!!".

A figura da coordenadora de tutoria como elemento motivador do diálogo funcionou como um elemento surpresa em nossas análises, pois acreditávamos que a maior motivação para o diálogo viria da relação entre professores e tutores. Pudemos perceber a participação dessa coordenadora até mesmo em interação com alunos. No excerto a seguir, podemos perceber, de modo claro, uma demonstração por parte dela de motivação para que fosse mantido o diálogo, a interação e a permanência 
no curso. A coordenadora demonstra afeto, atenção e interesse em ouvir o aluno e oferece o seguinte feedback:

XXXX, essa é uma notícia muitoooooooooooooooo boa. É claro que posso te ajudar. A primeira coisa a fazer é ficar calma, depois é ver as atividades que faltam e ir fazendo devagar. Vi que você realmente entrou na Unidade 4 do curso e escreveu na Atividade 1 que é um fórum. Os fóruns são todos semelhantes normalmente têm alguma pergunta sobre o tema e você vai escrevendo sobre o que sabe do seu conhecimento ou sobre o texto do curso. 0 importante nos fóruns é a participação e interação com os outros colegas. Nos diários você escreve o que você sabe ou o que você aprendeu sobre aquele assunto. Quando fizer os diários escreva a data e o número da atividade e salve, nunca apague o diário anterior. (Registro de interação entre aluno e Coordenadora de Tutoria).

Por meio desse excerto, pode-se perceber que o diálogo flui de modo natural e serve aos princípios teórico-metodológicos da aprendizagem colaborativa, unindo instrução e interação e reflete os níveis de incorporação da tecnologia aos processos de ensino e aprendizagem do curso. Esse excerto nos mostra também que a distância que separa a coordenadora do aluno é transacional, no sentido de que o espaço geográfico e temporal que separa esses dois agentes ficou imperceptível sendo trabalhado de modo pedagógico.

A coordenadora realiza orientações à aluna e ainda a incentiva a participar e interagir nos fóruns. Acreditamos que essa postura de orientação por parte da coordenadora influenciou positivamente no desempenho da aluna no curso, demonstrando que as relações de interação e diálogo favorece a autonomia do aluno na busca pelo conhecimento e ainda produz implicações nos resultados alcançados pelos alunos no curso.

No que se refere à interação professor formador e tutor, a ferramenta mais utilizada foi e-mail interno. Enquanto os fóruns de interação quase não foram utilizados para sanar dúvidas ou passar orientações, os e-mails internos foram maciçamente utilizados. Nossas análises nos mostraram que o fator que favoreceu a utilização maciça do e-mail interno foi o tempo utilizado para as respostas. Isto é, a necessidade de um feedback rápido levou professores e tutores utilizarem o e-mail como mecanismo de interação e diálogo entre os agentes. Nesse caso, a dimensão estrutura funcionou com apoio que contemplou a interatividade como recurso informático de uma educação que acontece em ambiente on-line. 
No geral, os fóruns que seriam utilizados para interação, troca de experiências, orientação, e para sanar dúvidas ou problemas foram utilizados de maneira breve com orientações simples. Por exemplo: Professor 1) "Prezadas Tutoras, precisamos marcar um encontro presencial para tratarmos assuntos sobre a dinâmica dos Cursos", Professor 2) "Olá XXX, poste suas dúvidas", Professor 3) "Estou por aqui, qualquer dúvida, estou à disposição!". Ao fazermos um levantamento quantitativo de momentos de interação via ferramenta fórum, percebemos que apenas dois dos 17 professores alcançaram mais de 5 acessos em seus fóruns abertos. Esse resultado nos leva a perceber que a ferramenta fórum, que a princípio nos pareceu a que mais favoreceria a inter-relação entre tecnologia (estrutura), diálogo (interação) e autonomia, não demonstrou um resultado satisfatório, já que o seu uso pareceu-nos de modo muito tímido e, às vezes, ineficiente.

Por outro lado, pareceu-nos que a ferramenta de "e-mails internos" supriu esse vácuo no que se refere às variáveis que envolvem a Educação a Distância, propostas por Moore (1993). Pudemos vislumbrar a ocorrência de todas essas variáveis, para assegurar uma distância transacional pedagógica e relevante para a qualidade e a dinamização do processo ensino e aprendizagem do curso. Os excertos, a seguir, demonstraram que a extensão da distância transacional como um programa educacional, nesse curso, não envolveu apenas as variáveis tecnológicas ou comunicacionais como normalmente é destacado nas pesquisas atuais, mas sim, variáveis em ensino e aprendizagem, e na interação entre ensino e aprendizagem:

Professor para tutor: "Olá, Meninas, bom dia! Gostei muito da ideia de poder continuar trabalhando com vocês, nessa nova turma! Gostaria que fizessem um acompanhamento de perto para os alunos que tem pouco acesso ou que somem da plataforma. Já vão se cercando de o máximo de informações possíveis sobre os alunos, para fazer aquele trabalho de motivação a tempo e a hora que vocês já estão acostumadas. OK? Então, sentiu falta do aluno na atividade, nos fóruns por no máximo dois dias, eu gostaria que já buscassem informações, entrassem em contato com eles e se disponibilizem para ajudá-los. Lembrem-se um curso a distância o foco é no aluno. Vamos fazer o máximo para mantê-los ativos e evitar ou reduzir evasão. Um abraço alegre a todas e estou a disposição!"

Tutora para professor: "Olá Professora XXXX! Como vai?

Também adorei ter você como nossa professora formadora. Espero que façamos um excelente trabalho. Seguirei as suas orientações e qualquer problema comunico com você. Um grande abraço!” 
Tutora para aluno: "Percebi que você ainda não acessou o curso. 0 que está acontecendo? Você está com algum problema ou dificuldade no acesso? Para acessar o curso você deve os seguintes passos:

1ํ. Entrar no endereço www.xxx.xxx.br

2‥ Digitar o seu CPF no quadro de Nome de usuário

3‥ Digitar a senha xxxxx no quadro logo abaixo".

Aluno para tutora: "Olá colegas cursistas, prazer em conhecê-los e poder compartilhar com todos vocês as experiências na educação de pessoas surdas. Desejo a todos muito sucesso!!! e que, juntos construamos novos saberes para o melhor encaminhamento na educação de nossos alunos e alunas com surdez!!! Em anexo, a síntese de um trabalho postado nessa área. Bom cursos e boas aprendizagens nessa caminhada acadêmica!"

Tutor para aluno: "O Suporte do curso lhe enviou uma resposta para regularizar o seu acesso na Plataforma, mas acredito que você já tenha resolvido, pois visualizei as suas atividades".

Tutor para aluno: "Parabéns pela finalização do curso.

Olha, que bom, saber que conseguimos finalizar tão bem o curso. Fiquei muito feliz de ter trabalhado com vocês. Foi um grupo muito producente". Aluno para o tutor: "Cheguei ao final do curso e agradeço a toda equipe do curso por proporcionar atividades e textos maravilhosos para meu crescimento no trabalho com o surdo. E meu carinho por você que sempre esteve presente nos meus clamores e minhas duvidas sempre com uma resposta carinhosa e de estimulo".

Nesse mecanismo, pudemos perceber que o papel motivador do professor e do tutor foi fundamental para que o aluno acessasse e postasse suas atividades e autoavaliações em tempo hábil. De modo diferenciado, houve destaque também para os e-mails internos em que os tutores pesquisados utilizaram bastante para estabelecer contato direto e rápido com o aluno e com o professor formador. Esse mecanismo se mostrou bastante eficiente, chegando a suprir a ineficiência de interação dos fóruns de interação do curso. Os próximos excertos demonstram bem a utilização do e-mail como forma de articular as variáveis e potencializar a distância transacional desse curso:

Tutor para aluno: Estamos sentindo sua falta na participação e interação com a nossa turma do "Curso AEE Surdos". A Unidade xx já começou e de acordo com o nosso calendário será finalizada até xxx. Gostaria de chamar a sua atenção, pois você ainda não inicializou as atividades desta unidade. Não se esqueça que a sua presença é fundamental para que 
possamos desenvolver um excelente trabalho. Qualquer dúvida estou à sua disposição. Abraços!

Tutor para aluno: Gostaria de lembrá-la quea Unidade I do Curso Atendimento Educacional Especializado para Alunos Surdos termina no dia xxx e estou muito preocupada, pois você não iniciou as atividades deste módulo. Peço por gentileza que se dedique nestes últimos dias para que possa concluir as atividades propostas. Seguem as atividades: Venha participar conosco, estamos esperando por você! Caso esteja com alguma dúvida ou problema, por gentileza me comunique para que eu possa ajudar e orientar.

Aluno para tutor: Boa tarde!!!. Finalmente, conclui as últimas tarefas que estão anexadas neste e-mail. Muito obrigado pelo apoio durante todo o curso! Um grande abraço.

Aluno para tutor: foi um prazer ter estudado este curso, sendo você tutora, considero você uma pessoa atenciosa e comprometida, no mais, Obrigado por tudo.

Sinceramente, $\mathrm{xxx}$.

Esses excertos demonstraram que no que se refere à interação em relação ao conteúdo e postagens de atividades os fóruns, os fóruns de dúvidas, e os diários de bordo foram fundamentais, pois serviram de estrutura para a consecução das atividades propostas pelo curso. 0 AVA atendeu seus propósitos nesse aspecto, apresentando poucos problemas de acesso. No que se refere ao contato direto, seja para auxiliar o aluno, pedir ou oferecer orientações, seja para agradecer no sentido de interagir, buscando um diálogo, o e-mail interno atendeu também o seu propósito. No contexto do curso, o e-mail interno foi fundamental para relacionar as variáveis da Educação a Distância ao potencializar a distância transacional que, nesse caso, exerceu um papel pedagógico e supriu a necessidade de um trabalho educativo executado na modalidade presencial.

Os resultados nos levaram a crer que a Educação a Distância pode funcionar de modo eficiente, mas vale lembrar que alguns elementos e variáveis devem ser respeitados, conforme proposta de Moore (1993). 0 ensino deve ser oferecido de modo contextualizado e por meio de uma estrutura eficiente de acesso fácil. Essa estrutura deve ser composta por um design instrucional claro, conciso e contextualizado, além de propiciar a acessibilidade. Nesse caso, a Plataforma Moodle serviu bem a esse propósito. A opção no design do curso foi pela aplicação de informações direcionais como conteúdo base. Essa ação foi para garantir que todos os alunos conseguissem navegar e acessar o curso de modo autônomo e funcional. 
A oferta do Curso Atendimento Educacional Especializado para Alunos Surdos foi realizada na modalidade a distância e on-line. Sendo assim, percebemos que essa distância possibilitou uma transação de alto nível entre os agentes envolvidos no processo: coordenadores, professores, tutores, alunos e equipe técnica. Sendo essa distância transacional, o diálogo foi favorecido e todos os elementos se articularam para propiciar autonomia na busca pelo conhecimento ao aluno. Isso significou que o aluno se auto responsabilizou pela qualidade de seu aprendizado e buscou $\mathrm{o}$ aprendizado significativo. Essa postura manteve o aluno ativo no curso e motivou sua permanência, o que reduziu os índices de evasão.

Em relação à autonomia do aluno, pudemos perceber que o empenho dos professores aliados aos dos tutores em manter um contato constante e de modo afetivo fez com que o curso conseguisse alto índice de aprovação, possibilitando meios para o aluno buscar, de modo autônomo, as informações. Ao passar orientações de modo claro, ao indicar leituras que fossem de interesse dos alunos, ao responder de maneira rápida e objetiva todas as dúvidas, os tutores propiciaram condições para que os alunos conseguissem uma aprendizagem significativa, e proporcionaram autonomia a esse aluno na busca e construção do próprio conhecimento.

Pudemos contar também com uma série de fatores como idade, profissão, área de interesse, objetivos dos alunos para com o curso, que influenciaram e permitiram que eles pudessem realizar o curso a distância com a autonomia prevista pela Teoria da Distância Transacional. 0 perfil dos alunos indicou que são todos profissionais e adultos em busca de aperfeiçoamento profissional, que já trabalham na área educacional, e que possuem nível médio completo e/ou graduação. Essas características favoreceram esses alunos que apresentam maior probabilidade de adquirir o conhecimento com autonomia por meio do curso que foi oferecido on-line.

Sobre a evasão, percebemos um índice aceitável. No que se refere a esse índice, creditamo-lo à falta de contato direto com alguns alunos, ou seja, alguns alunos que foram inscritos no curso não postaram os dados corretos como e-mails, telefones ou endereços. Sem ter uma forma de contato direto com esse aluno, os tutores não conseguiram evitar a evasão dos mesmos.

A função do professor formador foi a de assessorar o tutor, promovendo a sistematização e aprofundamento dos conteúdos apresentados no curso, esclarecendo dúvidas dos tutores e alunos, sempre que houvesse necessidade. Houve, desse modo, uma articulação entre as variáveis propostas pela Teoria da Distância Transacional que são a estrutura, o diálogo e a autonomia do aluno. 
Essa articulação tem possibilitado o desenvolvimento de sistemas interativos de aprendizagem na modalidade a distância, superando inúmeros desafios. E nessa dimensão da educação, o papel do professor como facilitador, provocador, e instigador da aprendizagem individual e coletiva é fundamental para que o processo ensino e aprendizagem aconteçam de modo qualitativo.

\section{Considerações finais}

As universidades estão se reorganizando e ultrapassando a função de transmissoras do conhecimento para diversas funções de reconstrução, de reflexão crítica e de produção de conhecimentos novos, sendo, também, responsáveis por capacitarem e acompanharem o professor em atividade nas escolas públicas fomentando a formação continuada desses profissionais.

Dessa forma, no que diz respeito aos cursos oferecidos na modalidade a distância, os processos de acompanhamento, as orientações e as formas de interagir com os alunos, constituem um conjunto de atividades didático-pedagógicas que sofrem significativas mudanças ao longo do tempo, sendo essas ações primordiais para o bom desempenho dos alunos. Assim, nas práticas didático-pedagógicas desenvolvidas por professores formadores e tutores no "Curso de Atendimento Educacional Especializado para Alunos Surdos" observa-se que há em desenvolvimento um novo tipo de relação pedagógica, fazendo com que os profissionais da área educacional, em especial, se atualizem, criem dispositivos de atendimento aos alunos, fomentem os espaços/fóruns de discussão e interação, incentivando a participação e a autonomia do aluno no desenvolvimento de suas práticas educativas.

Sendo assim, a condução da nossa pesquisa a luz da Teoria da Distância Transacional nos mostrou que a aprendizagem e o ensino acontecem mesmo a distância. Essa distância não deve ser extinta, mas sim, percebida como um fator pedagógico que motiva ações para desenvolver o ensino e proporcionar a aprendizagem em tempo e lugares distintos. Os princípios dessa teoria também nos mostraram que para que a educação ou formação aconteça mesmo a distância, deve haver a articulação entre o desenvolvimento tecnológico atual e sua integração aos sistemas de aprendizagem a distância.

Os dados mostraram a ferramenta que mais contribuiu na manutenção do diálogo e, portanto, da interação foi o e-mail, demonstrando que a forma direta de se comunicar prevaleceu como ferramenta a 
favor da interação. Nem os fóruns e nem mesmo o chat como espaço de comunicação síncrona alcançou a quantidade de uso tão eficiente quanto o e-mail que se constitui como espaço de comunicação assíncrona.

Logo, é essencial reconhecer que a articulação das dimensões estruturais de um Ambiente Virtual de Aprendizagem permeada por a um diálogo construtivo nos leva à aprendizagem colaborativa. E que o suporte (estrutura) que agrega o curso é de fundamental importância na manutenção da relação sistemática que ocorre entre agentes e entre os elementos que compõem o curso, pois proporciona um ambiente de aprendizagem de fácil acesso, favorecendo a autonomia do aluno. Essa relação, por sua vez, proporciona participação ativa do aluno no processo de aprendizagem, levando-o a conquistar sua autonomia na busca pelo conhecimento.

Nesse contexto, a atuação dos professores formadores e tutores, vão além de um conjunto de técnicas pedagógicas para solucionar as dúvidas e dificuldades diárias das situações educacionais, compreendendo uma das principais ferramentas para a capacitação dos professores em atividade na escola regular, os quais são os responsáveis por atender diretamente os alunos surdos, considerando suas peculiaridades e capacidades.

Percebemos que o trabalho desenvolvido por professores formadores e tutores incentivou os cursistas a buscarem o conhecimento. Essa ação interligada auxiliou os alunos, também na organização do tempo de estudo e no desenvolvimento das atividades. Nesse caso, a relação professor-tutor-aluno gerou um processo contínuo de aprendizagem e atualização, levando-os a adquirir os instrumentos para uma permanente renovação do saber. Essas ações conjuntas de orientação e acompanhamento denotam a necessidade de incentivar o estudo autônomo, de fazer uma leitura crítica das informações, de organizar o saber e de buscar o conhecimento.

Portanto, os professores formadores, os tutores e o Ambiente Virtual de Aprendizagem favorecem e orientam o desenvolvimento dos conhecimentos, das aprendizagens, dos avanços que desafiam os alunos, que propõem mudanças e incentivam a reflexão crítica dos professores da rede pública de ensino no sentido de promover uma verdadeira inclusão escolar dos alunos surdos e, principalmente, de derrubar as barreiras que impedem o prosseguimento dos estudos, um direito de todos os cidadãos brasileiros.

Esse tipo de ação demonstra, via resultados, que a formação/ capacitação pode ser feita a distância e, também, que pode se conseguir um resultado de qualidade no que se refere à formação dos discentes. Os 
resultados da oferta desse curso demonstram que uma articulação entre a educação e as tecnologias, quando respeitadas as variáveis (estrutura, diálogo, autonomia do aluno), é viável, bastante funcional e significativa. 


\section{Referências}

BEHAR, P. A.; PASSERINO, L.; BERNARDI, M.. Modelos pedagógicos para educação a distância: pressupostos teóricos para a construção de objetos de aprendizagem. Novas Tecnologias na Educação, Porto Alegre: CINTED-UFRGS., v. 5, n. 2, dez. 2007. Disponível em: <http://www.cinted.ufrgs.br/ciclo10/artigos/4bPatricia.pdf> Acesso em: 27 jan. 2010.

IBGE, Revista do Censo 2000 - Publicação do Instituto Brasileiro de Geografia e Estatística - IBGE. Centro de Documentação e Disseminação de Informações. Disponível em: <http://www.ibge.gov.br/censo/revista10.pdf>. Acesso em: 15 fev.2012.

LEITE, L. S.. Teoria da distância transacional e o processo de avaliação da aprendizagem em EAD. In: SILVA, M.; SANTOS, E. (Org.) Avaliação da aprendizagem em educação online: fundamentos, interfaces e dispositivos, relatos de experiências. São Paulo: Edições Loyola, 2006. p. 141-151.

MAIA, C.; MATTAR, J.. ABC da EAD: a educação a distância hoje. São Paulo: Pearson Prentice Hall, 2007. 138p.

MEC/INEP Censo Escolar. Evolução da educação especial no país. SEE/MEC Disponível em: <http://portal.mec.gov.br/seesp/arquivos/pdf/brasil.pdf> Acesso em: 15 fev. 2012.

MOORE, M. G. Theoretical Principles of Distance Education. London: Routledge, 1993. p. 22-38. Traduzido por AZEVÊDO, W., com autorização do autor. Revisão de tradução: SILVA, J. M. da. Revista Brasileira de Aprendizagem Aberta e a Distância, São Paulo, Ago. 2002. Disponível em: <http://www.abed.org.br/revistacientifica/ Revista_PDF_Doc/2002_Teoria_Distancia_Transacional_Michael_Moore.pdf > Acesso em: 9 fev. 2010.

MORAN, J. M.. Contribuições para uma pedagogia da educação on-line. In: SILVA, M.. Educação online: teorias, práticas, legislação, formação corporativa. São Paulo: Loyola, 2003. p. 39-50.

PELLANDA, N. M. C.; SCHLÜNZEN, E. T. M.; SCHLÜNZEN JÚNIOR, K. (Org.). Inclusão digital: tecendo redes afetivas/cognitivas. Rio de Janeiro: DP\&A Editora, 2005. 376 p.

ROGERS, C. R.. Liberdade para aprender. Tradução Edgar Godói da Matta Machado e Márcio Paulo de Andrade. 4. ed. Belo Horizonte: Interlivros, 1978. 330 p.

FALEIRO, W.; SOUZA, V. A. de, SILVA, L. C. da. Perfil dos professores que participam do curso de extensão "Professor e surdez: cruzando caminhos, produzindo novos olhares”. In: SILVA, L. C.; DECHICHI, C.; MOURÃO, M. P. (Orgs.). Políticas e práticas de formação continuada de professores para educação especial: alguns olhares sobre o curso de extensão "Professor e surdez: cruzando caminhos, produzindo novos olhares”. Uberlândia: EDUFU, 2010. p. 32-70.

SILVA, L. C. da. A política de formação continuada de professores e a educação especial: algumas reflexões. In: SILVA, L. C.; DECHICHI, C.; MOURÃO, M. P. (Orgs.). Políticas e práticas de formação continuada de professores para educação especial: alguns olhares sobre o curso de extensão "Professor e surdez: cruzando caminhos, produzindo novos olhares”. Uberlândia: EDUFU, 2010. p. 11-31. 


\title{
CAPÍTULO VI \\ A POLÍTICA NACIONAL DE FORMAÇÃO CONTINUADA \\ DE PROFESSORES E A EDUCAÇÃO ESPECIAL: \\ COMPREENDENDO A ACESSIBILIDADE
}

\author{
Lázara Cristina da Silva ${ }^{1}$ \\ Andréa Pires Dayrell da Cunha Pereira ${ }^{2}$ \\ Letícia Rodrigues de Castro \\ Ludmile Cristine Mendes Santos
}

No campo educacional, há um conjunto de temáticas que constituem desafios para a formação continuada dos profissionais da educação. Este estudo irá tratar da formação de professores vinculada à preocupação e compromisso com a ampliação das possibilidades de desenvolvimento e aprimoramento de políticas e práticas de formação docente para atuação nos processos educacionais atuais, principalmente no Atendimento Educacional Especializado - AEE.

Este artigo é parte das atividades previstas na pesquisa "A Política Nacional de Formação Continuada de Professores e a Educação Especial", financiada pelas agências de fomento à pesquisa Conselho Nacional de Desenvolvimento Científico e Tecnológico - CNPq e Fundação de Amparo à Pesquisa do estado de Minas Gerais - Fapemig. Tem por objetivo geral refletir sobre as políticas e procedimentos de formação continuada de professores para atuar nos processos de escolarização de pessoas com deficiência, transtornos globais do desenvolvimento e altas habilidades/ superdotação, no contexto de ascensão e consolidação da Educação Inclusiva na realidade brasileira.

Como objetivos específicos, pretende-se: a) compreender os sentidos atribuídos às ações desencadeadas pela Rede de Formação Continuada de Professores em Educação Especial da SEESP ${ }^{3}$ (Secretaria de Educação Especial), acerca do processo de escolarização de pessoas com

\footnotetext{
${ }^{1}$ Docente - FACED/UFU - Avenida João Naves de Ávila 2121, Bairro Santa Mônica. CEP 38400-902 Uberlândia/MG - lazara@ufu.br

${ }^{2}$ Graduanda em Pedagogias - FACED/UFU - Bolsistas de Iniciação Científica CNPq e Fapemig.

${ }^{3}$ Em 2011, com a nova configuração do Governo Federal, a Secretaria de Educação Especial se transformou em Diretoria de Políticas Pedagógicas de Educação Especial, parte da Secretaria de Educação Continuada, Alfabetização, Diversidade e Inclusão - SECADI.
} 
deficiências, transtornos globais do desenvolvimento e altas habilidades/ superdotação, realizadas durante os anos de 2009 e 2010; b) identificar e analisar os critérios considerados pela equipe coordenadora da rede e professores coordenadores dos cursos apresentados em resposta ao Edital n.o 1, de 02 de março de 2009, relativos à chamada pública para cadastramento e seleção de cursos de instituições públicas de educação superior para a Rede de Formação Continuada de Professores na Educação Especial, no Âmbito do Sistema Universidade Aberta do Brasil - UAB, para dizer que um curso atende à perspectiva inclusiva; c) aprofundar reflexões sobre a concepção de Formação Continuada de Professores em Educação Especial presente nas propostas desenvolvidas pelo governo federal no contexto atual; d) diagnosticar e analisar o perfil dos cursistas que participam da Rede de Formação Continuada de Professores em Educação Especial no âmbito da UAB, apreendendo as motivações da adesão; e) identificar o índice de evasão dos cursistas e apreender os condicionantes que levaram à deserção; f) comparar os índices de evasão de acordo com a forma de adesão aos cursos da Rede de Formação de Professores em Educação Especial.

Este artigo irá abarcar uma parcela do trabalho, centrando a análise em cinco dos cursos previstos.

\section{Situando o universo do estudo}

As demandas por formação continuada de professores para atender às questões relacionadas aos processos de escolarização das pessoas com deficiências, transtornos globais do desenvolvimento e altas habilidades/superdotação passam a ter destaque no cenário nacional, realizando debates sobre as políticas educacionais nacionais no que tange à ampliação das condições de acesso e de permanência com sucesso desse grupo de pessoas nos espaços escolares.

Nóvoa (1991) defende que a discussão sobre a formação continuada de professores precisa ser inserida no campo dos estudos e debates sobre as políticas educativas e a profissão docente. Em se tratando do Brasil, essa é uma demanda atual, um direito conquistado e expresso no paradigma oficial, constituído e regulamentado pela legislação educacional nacional, determinando que toda escola brasileira seja naturalmente inclusiva.

No entanto, ao considerar a história educacional do país, pode-se observar que a escolarização não foi sempre destinada a todos, mas a uma parcela privilegiada da população. Aos poucos foi criado e ampliado, no país, um conjunto de situações e experiências que evidenciam a 
naturalização da exclusão, particularmente, entre os profissionais que trabalham na escola.

Hoje esse discurso parece superado, mas persiste a necessidade de ir além das experiências excludentes nos ambientes escolares. Assim considerando, a preparação e formação de professores torna-se essencial tanto em relação às questões que dizem respeito ao discurso, quanto à vida cotidiana no interior das escolas. 0 processo de formação docente seja inicial e/ou continuada precisa ter condições teóricas e práticas condizentes com as demandas de escolarização de todos, contemplando as especificidades das diferentes formas de deficiências, transtornos globais do desenvolvimento e altas habilidades/superdotação.

Historicamente, o Ministério da Educação, por meio da Secretaria de Educação Especial, tem procurado trabalhar no sentido de oferecer subsídios teóricos e financeiros aos sistemas de ensino, para que cada entidade assuma a própria responsabilidade legal e desenvolva ações de formação continuada aos seus profissionais. Na década de 1990, o paradigma da Educação Inclusiva no Brasil assumiu caráter normativo, em todo o território nacional, devido às proposições da Lei n. 9.394/96.

Nesse contexto, intensificou-se, também, a necessidade de se desenvolver ações a pequeno, médio e longo prazo, para garantir a qualificação dos profissionais da educação, não só docentes, mas também gestores, pessoal da área administrativa, etc., para assegurar o direito de acesso e permanência de todos os alunos nos contextos escolares comuns, inclusive de alunos com diferentes formas de deficiências, transtornos globais do desenvolvimento e altas habilidades/superdotação.

Atendendo às tendências de gestão da época, foram descentralizadas as obrigações e ações de formação continuada dos profissionais para atuar na escola inclusiva nos sistemas de ensino. Com o passar dos anos, após avaliações desencadeadas pela própria SEESP/MEC, foi averiguado que esses projetos não estavam, em muitos casos, atendendo às necessidades apontadas pelos profissionais. É importante destacar que essa formação estava sendo assumida por instituições privadas, com fins lucrativos, e que as universidades públicas eram deixadas à margem do processo.

Diante dessa realidade, a SEESP/MEC, motivada pelos dados representativos do INEP/2006 que demonstravam a ampliação do número de ingresso de alunos com diferentes formas de deficiências, transtornos globais do desenvolvimento e altas habilidades/ superdotação na rede pública de ensino, resolveu, por meio do Edital n. ํ 02/2008, criar a Rede de Formação Continuada de Professores em Educação Especial. 
Nesse edital, foram aprovadas 19 propostas. Todos os projetos, com exceção do Curso de Especialização, foram realizados na modalidade a distância, utilizando ambientes via web. Cada curso possuía vinte turmas com vinte a vinte cinco cursistas, totalizando cerca de 500 participantes. Nessa primeira edição, participaram cerca de nove mil e quinhentos professores. Foram ofertadas, na maior parte dos cursos, duas turmas. Os Cursos de Extensão possuíam uma carga horária de 120 horas, os de Aperfeiçoamento 180 horas e os de Especialização 365 horas.

Em 02 de março de 2009, O MEC/SEESP lançou o Edital n.․ 1, no qual realiza uma segunda chamada pública para o cadastramento e seleção de cursos de Instituições Públicas de Educação Superior para a Rede de Formação Continuada de Professores na Educação Especial no âmbito do Sistema Universidade Aberta do Brasil - UAB.

Foram aprovados três projetos de Cursos de Especialização lato sensu em Atendimento Educacional Especializado - AEE, oferecidos por três instituições públicas. Foram aceitas outras três propostas de Cursos de Extensão/Aperfeiçoamento, também em AEE, com carga horária de 180 horas. Atendendo ao mesmo edital, foram aceitas outras cinco propostas também de Extensão/Aperfeiçoamento, destinadas aos Professores do Ensino Regular. Existem, atualmente, três Cursos de Especialização ofertados na Rede de Formação Continuada de Professores em Educação Especial a distância, envolvendo cerca de três mil cursistas, e oito cursos de Extensão/Aperfeiçoamento, atendendo aproximadamente oito mil professores por semestre.

Diante do panorama exposto, é importante esclarecer algumas questões: Que diretrizes e princípios, acerca da Formação Continuada de Professores em Educação Especial, as propostas dos cursos selecionados apresentam? Qual o alcance do curso para os profissionais da educação? Como aconteceu o movimento de adesão dos professores aos cursos? Qual é o número de concluintes? Qual o nível de evasão e quais os principais motivos causadores do abandono dos cursos? A forma de adesão aos cursos da Rede de Formação de Professores em Educação Especial oferece algum impacto quanto ao número de concluintes?

Para a apresentação da proposta de trabalho e esclarecimento, foi elaborado e encaminhado aos coordenadores dos cursos aprovados e para a Secretaria da Educação Especial e coordenação da Diretoria de Políticas Pedagógicas de Educação Especial um documento em que são explicitados seus objetivos e um termo de aceite, para colaborar com a pesquisa, havendo a adesão de todos. 
No entanto, foram recebidos até o momento, os documentos de cinco universidades, sendo que apenas uma encaminhou o projeto do curso. A SEESP, por sua vez, encaminhou o Projeto Político Pedagógico elaborado com a finalidade de subsidiar a seleção dos projetos recebidos em resposta ao Edital n.․ 1 MEC/SEESP, de 02 de março de 2009.

Para este artigo foi realizado um recorte, focando apenas as ferramentas e recursos utilizados nos cursos, visando identificar e analisar as condições de acessibilidade dos mesmos.

\section{Os cursos: ferramentas/recursos utilizados}

Para atender ao objetivo específico da pesquisa, que se propõe diagnosticar e analisar as condições de acessibilidade das plataformas dos cursos da Rede de Formação Continuada de Professores em Educação Especial, no âmbito da UAB, foram considerados corpus desta etapa do estudo os seguintes cursos: a) Práticas em Educação Especial e Inclusiva na área da deficiência mental, ofertado pela UNESP de Marília, com a primeira edição no primeiro semestre de 2007, e em 2009 foram realizadas duas edições; b) Tecnologia Assistiva, Projetos e Acessibilidade: promovendo a inclusão, da UNESP de Presidente Prudente, com uma oferta no primeiro semestre de 2010; c) "Educação Especial e Atendimento Educacional Especializado", da Universidade Federal de Uberlândia - UFU, sendo uma edição em 2009, e duas em 2010; "Professor e Surdez: cruzando caminhos produzindo novos olhares", com duas edições em 2009, também ofertado pela UFU; d) "Atendimento Educacional Especializado para Pessoas Surdas", com duas edições em 2010, da Universidade Federal de Uberlândia - UFU.

Após análise desses cursos, realizou-se uma seleção e apreciação de diversos fatores apresentados. A acessibilidade foi considerada questão central nos cursos, ponderando que os mesmos destinam-se a formar professores para o trabalho pedagógico cotidiano com estudantes que requerem a utilização desses recursos. A presença dos recursos e ferramentas representa um veículo de formação inserido no próprio processo. Portanto, em um primeiro momento, dedicou-se especial atenção à compreensão das plataformas nas quais os cursos estão hospedados e suas possibilidades de acessibilidade, para, em seguida, observar a presença ou ausência dessas ferramentas nos cursos. As edições em que esses dados foram analisados estão relacionadas a seguir:

a) "Práticas em Educação Especial e Inclusiva na área da Deficiência Mental”, edições de 1a a 3a edição, 1/2007 a 1/2009, representando uma edição por ano, realizadas na Plataforma 
Teleduc, a partir de cadernos didáticos, propostas de atividades práticas, indicações de links, vídeos e bibliografia básica; elaboração de listas de discussão online, chats, fóruns, confecção de blogs e fologs, correspondência via e-mail, além de análise de filmes, leituras de imagem de livros produzidos. A $1 \underline{\text { a }}$ edição, $1 / 2010$, foi efetuada pela Plataforma Moodle, que apresenta ferramentas de interação, tais como fóruns e chats, com a presença virtual ou não do professor ou dos tutores, podendo disponibilizar materiais complementares para acesso aos alunos.

b) "Tecnologia Assistiva, Projetos e Acessibilidade, Promovendo a Inclusão", edição 1/2010, realizada na Plataforma Teleduc, a partir de material didático on-line, explorando três Objetos de Aprendizagem (OAs): "Alfabetização", "Fazenda Rived" e "Scrapbook"; Design Pedagógico, Manual do Usuário e Guia do Professor.

c) "Atendimento Educacional Especializado", edição 2/2009, realizada pela Plataforma Moodle, por meio de textos produzidos por pesquisadores da área, leituras complementares, e filmes. Esse curso deu origem a um livro didático distribuído gratuitamente aos cursistas.

d) "Atendimento Educacional Especializado para Pessoas Surdas", 1a a $2^{\text {a }}$ edição, $1 / 2007$ a 1/2010, representando uma edição por ano. Esses cursos foram realizados na Plataforma Moodle, com uso de chats, fóruns, wiki, mural, dicionário de Libras com todos os sinais utilizados no curso, enquetes, utilização de textos e realização de discussões, videoaulas, pequenos filmes, HTML e Flash, portfólio, vídeo conferências, biblioteca, FAQ, atividades objetivas, dissertativas de verificação, interativas e lúdicas, que utilizam os sinais da Libras, além de pesquisas e questionários, diário de bordo, livros on-line.

Segundo Evangelista e Hekcler (2006), é possível afirmar que a evolução da informática e dos meios de comunicação atingiu todos os níveis da sociedade, da vida profissionalà vida privada, fortalecendo a globalização do conhecimento. Com o avanço da rede mundial de computadores, são utilizadas novas tecnologias disponibilizadas pela informática, facilitando a comunicação entre as pessoas de qualquer parte do mundo.

Cria-se, portanto, uma oportunidade de mudança na forma de relacionamento dos professores com seus respectivos alunos, das instituições de ensino com a sociedade, [...], permitindo que as instituições 
de ensino se tornem mais próximas da sociedade e que os estudantes se sintam mais envolvidos no processo educativo (Evangelista \& Heckler, 2006, p. 2).

Como ferramentas para o Ensino a Distância, as plataformas utilizadas podem tornar-se instrumentos auxiliares para serem explorados como apoio didático pelo professor. Nos dados obtidos, destacam-se dois ambientes utilizados para a realização dos cursos em estudo: Teleduc e Moodle, cada um com características próprias conforme abaixo relacionado.

\subsection{Plataforma Teleduc}

Este ambiente teve como alvo o processo de formação de professores, a partir da metodologia de formação contextualizada, desenvolvida por pesquisadores do NIED (Núcleo de Informática Aplicada à Educação), da Unicamp, a fim de promover a criação, participação e administração de cursos na web. Essa plataforma tem características que as diferenciam dos demais ambientes da Educação a Distância disponíveis no mercado, como a facilidade e flexibilidade de uso por pessoas não especialistas em computação, e a um conjunto enxuto de funcionalidades.

Visando a comunicação entre os participantes do curso e a ampliação da visibilidade dos trabalhos desenvolvidos, foi elaborado amplo conjunto de ferramentas de comunicação, como: Correio Eletrônico, Grupos de Discussão, Mural, Portfólio, Diário de Bordo, Bate-Papo etc., além das ferramentas Intermap e Acessos, possíveis de serem utilizadas para consulta às informações geradas no curso.

A Plataforma Teleduc é um software livre, que pode ser redistribuído e/ou modificado conforme os termos da General Public License - GNU, versão 2, publicada pela Free Software Foundation. De fácil instalação, é traduzido em três línguas (inglês, espanhol e português), utilizado em mais de quatro mil instituições cadastradas.

\subsection{Plataforma Moodle}

A Plataforma Moodle é um Course Management System - CMS, também conhecido como Learning Management System - LMS ou Ambiente Virtual de Aprendizagem - AVA. É um aplicativo web, gratuito, que os educadores utilizam na criação de sites de aprendizado, capaz de propiciar aos educadores melhores ferramentas para gerenciar e promover a aprendizagem. 
Possui características que permitem usabilidade em grande escala,

envolvendo, simultaneamente, centenas de milhares de estudantes, podendo também, ser usada por instituições escolares de diferentes níveis e modalidades de ensino. Muitas instituições utilizam a plataforma para realização de cursos totalmente on-line, outras como instrumento de contato em seus cursos. Os módulos de atividade podem também ser utilizados para construir comunidades colaborativas de aprendizagem em torno de um tema. Há também aqueles que a utilizam como meio de compartilhar conteúdos com os alunos, além de permitir a avaliação da aprendizagem, utilizando diferentes ferramentas de atividades.

o download é gratuito, com registro voluntário, e utilizado principalmente num contexto de e-learning ou b-learning, permitindo a criação de cursos on-line, páginas de disciplinas, grupos de trabalho e comunidades de aprendizagem.

De acordo com Santana (2006), em 2008 estava disponível em 90 línguas, contava com aproximadamente 25.000 websites registados, em mais de 206 países. É desenvolvido colaborativamente por uma comunidade virtual, que reúne programadores e criadores de software livre, administradores de sistemas, professores, designers e usuários do mundo todo. Este é um aspecto que deixa a plataforma altamente atrativa, pois as experiências e demandas de grupos diferentes promovem sua constante adequação e ampliação, tornando-a flexível e "plástica".

A Plataforma Moodle apresenta para o ensino: a) Aumento da motivação dos alunos; b) Maior facilidade na produção e distribuição de conteúdos; c) Partilha de conteúdos entre instituições; d) Gestão total do Ambiente Virtual de Aprendizagem; e) Realização de avaliações de alunos; f) Suporte tecnológico para a disponibilização de conteúdos, de acordo comum modelo pedagógico escolhido pelo curso e design institucional; g) Controle de acessos e; h) Atribuição de notas.

É composta por recursos dinâmicos disponibilizados pelo professor/formador: locais de debate, partilha de ideias e esclarecimento de dúvidas, questionários e pesquisas com diversos formatos, gestão de Base de Dados, Chats, podendo ser utilizada para conversação em tempo real, Glossários, Suporte Multidioma, permitindo a interação entre professor/formador e alunos.

\subsection{Teleduc versus Moodle}

Após elencar os fundamentos e características de cada plataforma, é possível perceber que em ambas há recursos fundamentais para a 
execução do programa de formação continuada de professores, visto que esses recursos possibilitam o acesso dos professores e de outros profissionais da área, mesmo dos leigos em informática, o que facilita o estudo em uma área específica.

No que diz respeito à Plataforma Moodle, considerando o número de usuários, o tempo de permanência/disponibilização, e a constante ampliação e atualização, é possível deduzir que esse é um recurso que apresenta diversas ferramentas que possibilitam funcionalidade, plasticidade, flexibilidade e efetividade, além de amplos meios estratégicos para a execução de atividades.

A Plataforma Teleduc, por sua vez, é acessada por um menor número de usuários, o que pode ser explicado por sua disponibilidade ocorrer em apenas três línguas, limitando sua procura.

Ambas disponibilizam subsídios, de acordo com a proposta de cada projeto. A Plataforma Moodle se destaca no que tange à sua diversidade de materiais, promovendo maior facilidade na produção e na socialização de conteúdos, na realização de avaliações, no suporte tecnológico para a disponibilização, no controle de acessos e atribuição de notas.

\section{Acessibilidade}

Em relação à acessibilidade dos cursos, foi possível observar nos dados coletados nos relatórios e nos projetos ${ }^{4}$ fatores questionáveis, como no caso do curso "Práticas em Educação Especial e Inclusiva na Área da Deficiência Mental". Nesse material a questão da acessibilidade é abordada apenas na $3^{\underline{a}}$ edição de 2008 e na 1aㅡ edição de 2010. 0 Curso Atendimento Especializado para Pessoas Surdas se preocupa com a acessibilidade dos

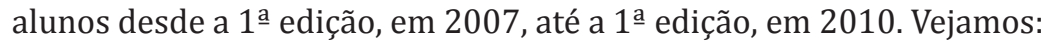

a) Na 1a edição em 2007, o material pôde ser impresso em Braile e/ ou ampliado, se necessário, a partir de conjunto de ferramentas que permite a utilização dos recursos com facilidade, possibilitando o acesso à informação. Mesmo sem o domínio da informática, esse acesso pôde ser realizado com facilidade, inclusive por apresentar

\footnotetext{
${ }_{4}$ Para esta análise, foram considerados apenas os relatórios e os projetos desses cursos oferecidos pelo MEC, aos quais foi possível o acesso, por meio da disponibilização, via e-mail, pelos coordenadores dos respectivos cursos. Foram consideradas algumas edições dos cursos: Práticas em Educação Especial e Inclusiva na Área da Deficiência Mental, Tecnologia Assistiva, Projetos e Acessibilidade, promovendo a inclusão, Atendimento Educacional Especializado e Atendimento Educacional Especializado para Pessoas Surdas.
} 
textos com letras grandes e legíveis, e ilustrações e linguagem próprias para tal.

b) Na 1a edição em 2008, utilizou-se metodologia interativa e contextualizada para ensinar a Libras e abordagens de temas que discutem as teorias e práticas sobre Educação Inclusiva e Surdez, abordadas nos processos formativos, na reforma curricular e seus impactos no âmbito educacional. Apresentada em formato acessível, contou também com suporte técnico para o esclarecimento de dúvidas quanto à navegação no curso e ao acesso à teoria, à metodologia e à avaliação. Os usuários têm acesso ao código fonte do software, podendo examinar, alterar, ampliar, modificar o programa ou mesmo usar partes dele para aplicações de interesse pessoal. Para que os alunos tenham acesso de forma eficaz e eficiente, é necessário que todas as informações forneçam descrição textual e a interrupção da legenda de sons automáticos ou repetitivos; da mesma forma, os objetos executáveis devem fornecer legendas e descrição sobre o seu funcionamento de preferência em Língua de Sinais.

c) Na $2^{a}$ edição em 2008, todo o conteúdo foi traduzido para a Libras e disponibilizado em CD-ROM. Nessa edição, o sítio e o ambiente de aprendizagem são explicativos com um conjunto de ferramentas que permite a utilização dos recursos com facilidade, possibilitando o acesso à informação, mesmo sem o domínio da informática. Foram mantidas as letras dos textos grandes e legíveis, as ilustrações e o tipo de linguagem utilizada para apresentação do conteúdo.

d) A 1a edição em 2009 trouxe a opção de alterar tamanho da fonte, contrastes de fundo de tela, compatíveis ao uso do ledor de tela e a presença de vídeos contendo a Libras.

e) Na 1a edição em 2010, os usuários tiveram acesso ao código fonte do software, podendo examinar, alterar, ampliar, modificar o programa, ou mesmo, usar partes dele para aplicações de interesse pessoal. Há a interpretação de Libras em todo o material produzido, bem como o áudio para que a acessibilidade seja garantida na realização do curso, além de legendas com a redação dos respectivos textos. Apresentou ainda, a sonorização das videoaulas e a gravação sonora da leitura dos textos utilizados favorecendo a participação do aluno cego ou com baixa visão.

Evidenciou-se, dessa forma, que apenas dois cursos apresentaram a preocupação com a acessibilidade; os demais cursos não foram 
mencionados, devido à ausência de informações em seus documentos, quanto à acessibilidade do curso. Ainda, assim, o Curso de Práticas em Educação Especial e Inclusiva na Área da Deficiência Mental expõe apenas que é acessível, sem mencionar maiores detalhes ${ }^{5}$. Nesse caso, persiste a questão de qual acessibilidade é abordada nesses relatórios, qual a razão de ser denominado "acessível". Que fator pode evidenciar tal afirmativa?

A terceira edição desse curso, ofertada em 2008, foi organizado na Plataforma Teleduc e a edição seguinte, em 2010, foi hospedada na Plataforma Moodle. Sendo assim, surgem os seguintes questionamentos: Quais os reais motivos para tal migração de plataforma? As duas ofertas do curso ofereceram os requisitos fundamentais para uma inclusão de fato? Seria possível que todo e qualquer cidadão, provido de alguma deficiência sensorial e/ou física, tivesse acesso ao curso?

É importante salientar que

o processo de construção do conhecimento em um ambiente colaborativo de aprendizagem centra sua abordagem no papel ativo dos participantes dentro de um processo de reflexão na ação, interatividade e colaboração feita entre os envolvidos de modo a desenvolver uma aprendizagem significativa (Santana, 2008, p. 2).

Para a autora em questão a Plataforma Moodle se destaca das demais por apresentar não somente a adaptabilidade e a usabilidade, mas também por não possuir custo na aquisição de licenças e, ainda, por ser compatível com qualquer sistema operacional.

O Ambiente Virtual de Aprendizagem Moodle, não só trata a aprendizagem como uma atividade social, como focaliza a atenção na aprendizagem enquanto construímos artefatos (como textos), para que outros os vejam ou utilizem (Dougiamas, 2008, p. 2).

Esse ambiente tem se mostrado instrumento de inclusão no aprendizado por ser colaborativo, plural, possibilitando a interação e o compartilhamento de conhecimentos entre os envolvidos.

Por sua vez, as ferramentas de comunicação presentes no ambiente Teleduc também visam a formação e a interação dos participantes do curso.

\footnotetext{
${ }^{5}$ Essas questões serão apresentadas na segunda etapa do estudo, por ocasião da entrevista com a coordenadora.
} 
Propicia a criação de uma estrutura de curso dinâmica, adequando um ambiente de estímulo, motivação e envolvimento no processo de ensino e de aprendizagem, permitindo, assim, que os alunos participem ativamente da aquisição de informações e construção do seu conhecimento.

Segundo Santana (2008), uma formação integral supõe a necessidade de inclusão de ferramentas de controle do aluno sobre o seu aprendizado, de um organograma para melhor visualização do contexto total, vídeos ao vivo ou webconferência, bem como maior controle sobre os questionamentos postados no fórum, que viria conquistar e ampliar a utilização do ambiente virtual.

No entanto, pelo desconhecimento de muitos formadores das peculiaridades desse processo de formação dos profissionais da educação, o trabalho pode acontecer de forma oposta aos objetivos propostos e suas intenções, por mais coerentes que pareçam. Não se trata de transpor os modelos de educação inicial aos projetos de formação continuada, posto que cada fase de formação apresenta demandas e especificidades.

\section{Considerações}

Considerando a formação de profissionais para a escolarização de todos, faz-se necessário que o processo de formação docente, considere as condições teóricas e práticas condizentes com as demandas, a fim de atender as especificidades das diferentes formas de deficiências, transtornos globais do desenvolvimento e altas habilidades/superdotação.

Nessa perspectiva, a acessibilidade foi considerada ponto chave nos cursos, visto que a presença dos recursos e ferramentas que garantem sua acessibilidade representam um meio de formação inserido no próprio processo. Conforme Evangelista \& Heckler (2006), o uso de diferentes ferramentas no campo do ensino estimula a descoberta de novas formas de conhecimentos, por meio de trocas de experiências e informações simultâneas.

Essa busca pelo acompanhamento da tecnologia possibilita que os meios tecnológicos, providos pela Internet, propiciem um amplo auxílio à educação, seja pela interatividade entre pessoas ou por representar excelente meio de propagação de conhecimento. Percebemos que as Plataformas Teleduc e Moodle possibilitam uma didática interativa e acessível, criando um espaço maior para perguntas e participação de todos, além de respostas reflexivas do professor para os alunos e viceversa. Todavia, a ausência da acessibilidade não aconteceu em decorrência das plataformas, mas pela forma da organização dos cursos. 


\section{Referências}

ANDRADE, S. G. Pensamento sistêmico e docência no contexto da educação inclusiva. SEMINÁRIO DE PESQUISA EM EDUCAÇÃO DA REGIÃO SUL, 2004, Curitiba. In: BAPTISTA, C. R. Mediação pedagógica em perspectiva: fragmentos de um conceito nas abordagens institucional, sócio-histórica e sistêmica. Curitiba: Editora da PUC, 2004.

BRASIL. Lei n.ำ 9.394, de 20 de dezembro de 1996. Dispõe sobre as Diretrizes e Bases da Educação Nacional. Brasília: Congresso Nacional, Diário Oficial da União, 23 de dezembro de 1996.

Secretaria de Educação Especial. Política nacional de educação especial na perspectiva da educação inclusiva. Brasília: Ministério da Educação, 2008. 2008.

Secretaria de Educação Especial. Decreto n. 6.571, de 17 de setembro de

Dispõe sobre o Atendimento Educacional Especial. Brasília, Ministério da Educação, 18 set. 2008.

. Constituição 1988. Constituição da República Federativa do Brasil, promulgada em 5 de outubro de 1988. Brasília: Congresso Nacional, Imprensa Oficial, Diário Oficial da União, 1988.

EVANGELISTA, M. L. S. HECKLER, V. Teleduc - uma ferramenta auxiliar no processo educativo presencial da engenharia de produção. Disponível em: <http://www. abepro.org.br/biblioteca/ENEGEP2006_TR540365_8600.pdf>. Acesso em: 10 jul. 2011.

Moodle Org, Disponível em: < http://moodle.org/>. Acesso em: 01 jul.2011.

TelEduc Org, Disponível em: < http://teleduc.org/>. Acesso em: 01 jul.2011.

SANTANA, D. A. O uso da Plataforma Moodle na Educação a Distância como Forma de Democratizar o Ensino. Disponível em: <http://www.webartigos.com/ articles/20991/1/0-Uso-da-Plataforma-Moodle-na-Educacao-a-Distancia-comoForma-de-Democratizar-o-Ensino/pagina1>. Acesso em: 10 jul. 2011.

ROCHA, J. Reflexões sobre o Contemporâneo - 0 que é o Moodle? Disponível em: <http://julcirocha.wordpress.com/2007/11/28/o-que-e-o-moodle/>. Acesso em: 13 jul. 2011. 


\section{CAPÍTULO VII \\ A LIBRAS NO ATENDIMENTO EDUCACIONAL \\ ESPECIALIZADO: BASE PARA O LETRAMENTO EM LIBRAS E EM PORTUGUÊS}

Nelma Cristina de Carvalho ${ }^{1}$

Cristina B. F. de Lacerda ${ }^{2}$

O ensino-aprendizagem da linguagem escrita da língua majoritária (Língua Portuguesa) como segunda língua para surdos tem sido tema de diversos estudos desenvolvidos à luz de diferentes perspectivas teóricas. Por muito tempo acreditou-se que as dificuldades apresentadas por sujeitos surdos e os consequentes erros realizados por estes indivíduos na leitura e escrita, fossem causados por um déficit cognitivo imposto pela própria surdez (Svartholm, 1994; Watson, 1994, Goes, 1996).

Levando em consideração os resultados acadêmicos alcançados por alunos surdos incluídos na rede regular de ensino, torna-se premente uma intervenção neste campo, visando propiciar uma aprendizagem dos conteúdos escolares que sejam consistentes para eles, tornandoos capazes de ler e escrever a Língua Portuguesa de maneira autônoma ainda nas séries iniciais do ensino fundamental. Assim, abordar o ensino do português como segunda língua para os sujeitos surdos é de suma importância e tem sido defendido por vários autores preocupados com esta realidade (Lodi, 2004; Silva e Pereira, 2003).

É importante esclarecer que para que aja o acesso ao Português escrito, em uma proposta educacional bilíngue, este deve ser contextualizado a partir da Língua Brasileira de Sinais (Libras), já que esta é a língua de domínio destes alunos e aquela que pode melhor mediar a construção de novos conhecimentos. Além disso, o ensino da Língua Portuguesa para alunos surdos precisa ser pensado a partir das peculiaridades deste grupo. Um dos espaços que pode favorecer um trabalho, nesta perspectiva, são as salas de Atendimento Educacional Especializado - AEE, já que nelas o Português pode ser tratado como segunda língua sem prejuízo para alunos ouvintes que desenvolvem seus conhecimentos em Português como língua materna.

\footnotetext{
${ }^{1}$ Pedagoga formada pela PUCAMP/ Campinas- SP, Brasil. Professora da rede municipal de ensino de Campinas - São Paulo. Brasil

${ }^{2}$ Docente do Curso de Licenciatura em Educação Especial e do Programa de Pósgraduação em Educação Especial da Universidade Federal de São Carlos - UFSCar.
} 
É fundamental enfatizar, ainda, que devido à faixa etária das crianças que frequentam a primeira etapa do ensino fundamental (a maioria com menos de 10 anos), o domínio de Libras lhes é restrito. A maior parte dessas crianças desenvolve seus conhecimentos nesta língua na escola, no contato com seus colegas surdos, com o instrutor surdo e também com os intérpretes de Língua de Sinais. Justamente pelo fato das crianças surdas serem oriundas de famílias ouvintes, que frequentemente têm pouco ou nenhum contato com a Libras, elas não têm oportunidade de adquirir um bom desenvolvimento da linguagem nesta língua.

No Brasil, a Lei no 10.436, de 24 de abril de 2002, reconhece a legitimidade da Língua Brasileira de Sinais - Libras e, com isso, seu uso pelas comunidades surdas ganha respaldo do poder e dos serviços públicos. Essa lei gerou o Decreto n.ํㅜ 5.626, de 22 de dezembro de 2005, que torna obrigatório o ensino da Libras aos estudantes dos cursos de Fonoaudiologia, Letras, Licenciatura e Pedagogia, Magistério e nos cursos de Educação Especial. A obrigatoriedade dessa lei amplia as possibilidades de, futuramente, o trabalho com surdos ser desenvolvido de forma a respeitar sua condição linguística diferenciada. 0 decreto focaliza a importância de a educação considerar a Libras nos processos educacionais de alunos surdos, e exige que o Português seja ensinado como segunda língua para os alunos surdos nos diferentes níveis de ensino por professor bilíngue com competência para essa atividade.

Contudo, poucos são os locais no Brasil que têm experiência com a prática de ensino de Português como segunda língua para alunos surdos em qualquer nível de ensino. Pela política educacional brasileira, que advoga a inclusão, e pela recente oficialização da Libras, torna-se fundamental discutir estratégias didáticas que permitam o amplo letramento de alunos surdos no Português escrito. Trata-se de um conhecimento novo que precisa ser construído também a partir das práticas que vêm sendo desenvolvidas por professores bilíngues e seus alunos surdos no cotidiano escolar (Lodi e Lacerda, 2010).

Assim, esse artigo, em uma proposta de inclusão escolar bilíngue, procura abordar aspectos de uma experiência de ensino de Português escrito para um grupo de dezesseis adolescentes surdos que frequentam do sexto ao nono ano do ensino fundamental, em uma escola pública da rede regular. A experiência que será aqui relatada poderá ser implementada em espaços de Atendimento Educacional Especializado - AEE, desde que o professor responsável seja bilíngue com fluência em Libras, e aprofunde seus conhecimentos em modos de ensinar a escrita da Língua Portuguesa como segunda língua, apoiando-se em aspectos da gramática da Libras. 
Na experiência focalizada, os adolescentes são acompanhados por intérpretes de Língua de Sinais em sala de aula regular para o acesso e aprendizagem dos diversos conteúdos acadêmicos. Já para o ensino do Português escrito, os alunos surdos participam dessas aulas em um espaço reservado só para eles, pensado para o ensino do Português escrito como segunda língua. Essas aulas de Português são ministradas em Libras com o objetivo de favorecer o letramento em Português escrito destes alunos.

\section{Discutindo o ensino de Português escrito mediado pela Libras}

As aulas de Língua Portuguesa, como segunda língua, são desenvolvidas em 06 aulas semanais ou mais, já que o atraso de letramento desses alunos é significativo. Nesse espaço, prioriza-se a participação dos alunos para ampliação de seus conhecimentos no Português escrito, que é a base para a aprendizagem de todas as demais disciplinas. Essas aulas são conduzidas por uma professora ouvinte bilíngue, fluente em Libras, com a participação sistemática de um instrutor surdo que colabora para evidenciar aspectos linguísticos ora da Libras ora do Português, favorecendo o letramento em ambas as línguas.

Nessas aulas, os participantes são adolescentes, com idades que variam entre 12 e 20 anos. 0 número total de alunos é dezesseis, sendo que oito desses alunos cursam o sexto ano, sete frequentam o sétimo ano e um frequenta o nono ano do ensino fundamental. Nas aulas de Português, geralmente, eles ficam agrupados, pois suas necessidades são semelhantes, e o professor aproveita a heterogeneidade de conhecimentos em Libras e em Português para favorecer trocas e expansão de conhecimento.

Dos alunos que foram acompanhados, sete são do sexo masculino e nove do sexo feminino. Esses alunos apresentam perdas auditivas que variam de moderada a profunda, havendo predomínio de perda profunda bilateral. Vale ressaltar que apenas três jovens do grupo são oralizados, mas ainda assim fazem um uso restrito do Português oral. Os outros treze adolescentes não utilizam essa linguagem, todos são usuários da Libras, com maior ou menor domínio, dependendo do tempo de exposição a essa língua, o interesse e a disponibilidade de familiares no uso da Língua de Sinais no ambiente doméstico.

Alguns desses alunos chegaram à escola com certo domínio de Libras aprendida em instituições de atendimento educacional e clínico que frequentavam, outros apenas com sinais caseiros. Destaca-se, porém, que o uso e o vocabulário em Libras foram ampliados rapidamente devido 
à frequência dos alunos nessa escola e no contato com um número maior de alunos e instrutores surdos.

Cabe lembrar que muitos desses alunos, anteriormente à experiência aqui descrita, frequentaram escolas especiais, outros frequentaram escola regular, contudo sem uma estrutura adequada de educação bilíngue, o que implicou na repetência de várias séries escolares para seis deles, resultando em um significativo atraso escolar. Portanto, no início desse trabalho fomos desenvolvendo atividades para melhorar a autoestima e, paralelamente, focalizar a ampliação do uso da Libras tanto no que diz respeito ao conhecimento do léxico, como no que se refere ao uso de diversos gêneros discursivos. Tais aspectos foram considerados fundamentais para alcançar o letramento em Português desses alunos.

Assim, o trabalho realizado procurava discutir aspectos da estrutura linguística do Português, ao mesmo tempo, envolvendo leituras e textos escritos que se voltassem para os "centros de interesse" dos alunos surdos.

É importante ressaltar que muitos enfrentaram, durante suas vidas, um certo isolamento social, o que gerou a ausência de conhecimento de fatos da vida cotidiana, justamente por possuírem um desenvolvimento restrito de Libras ou por possuírem um número restrito de interlocutores nesta língua. Desse modo, observamos que alguns conceitos conhecidos por jovens ouvintes, oportunizados por suas experiências sociais, eram inéditos para os jovens surdos, e esses conceitos precisavam ser trabalhados para que a interpretação e a compreensão de textos fossem possíveis para eles em muitos casos. Convém esclarecer que o conhecimento de mundo e de aspectos culturais são fundamentais para a atribuição de sentidos implicados nos processos de leitura e de escrita

Além disso, as aulas de Português foram preparadas com riqueza de materiais visuais tanto no que se refere aos conteúdos linguísticos quanto aos aspectos conceituais, para oferecer uma pedagogia visual de ensino especialmente pensada para esses alunos.

\section{Trabalhando com a identidade surda}

Logo no início das atividades foi possível perceber que muitos alunos não sabiam seu nome completo (nome e sobrenomes) e não compreendiam o sentido destes vários nomes. Assim, optamos por resgatar aspectos da identidade e da origem dos nomes dos alunos a partir de um documento oficial: a certidão de nascimento. De posse deste documento pudemos trabalhar vários conceitos como, por exemplo: a filiação e, consequentemente, a origem paterna e materna de cada um e a origem dos sobrenomes, questões de 
gênero, modos de organização familiar, genitores mortos ou vivos, presentes e ausentes e o local de nascimento. Além disso, refletimos sobre formas de reconhecer informações escritas no gênero textual "documento".
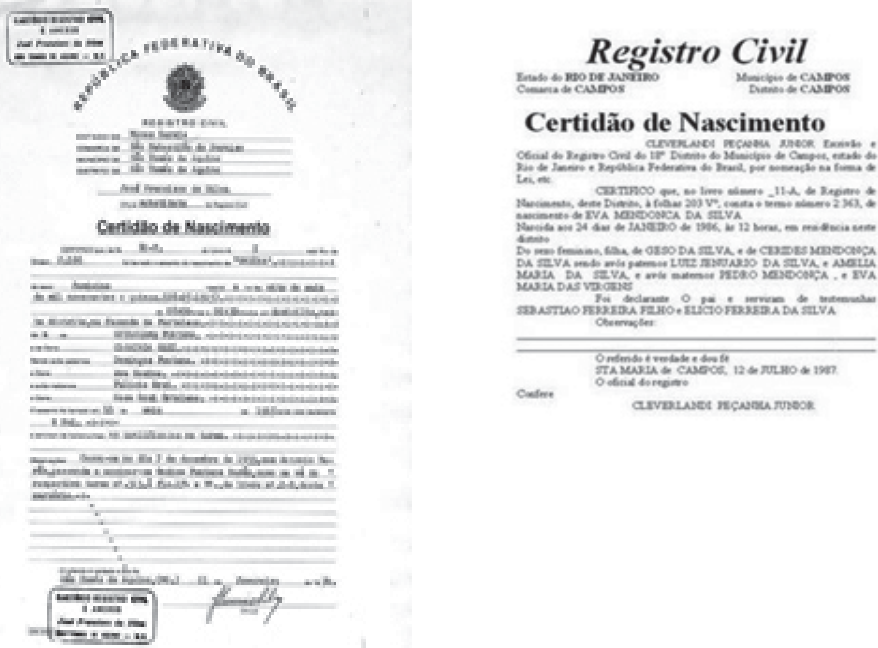

Esses dados nos propiciaram conhecer, detalhadamente, as histórias de vida dos alunos e dos seus familiares. Um dos aspectos mais explorados e de grande interesse do grupo foi o local de nascimento, ou seja, estado e município de origem. A maioria dos alunos migrou para o município, onde residem atualmente, em épocas distintas, e muitos se surpreenderam com esse fato. Diante disso, eles resolveram consultar suas famílias para saber o que as motivou a mudar do local de origem. Descobriram também qual foi o horário e o hospital que nasceram, o que permitiu um amplo debate sobre o parto, isto é, sobre as diferentes formas da mulher dar à luz a uma criança. A curiosidade em relação ao horário que cada um nasceu motivou uma pequena enquete na escola e fora dela, indagando as pessoas o horário que elas nasceram.

No decorrer das atividades, fomos percebendo que os alunos começaram a ter um maior interesse em relação às suas histórias familiares. Exemplo disso, foi o fato ocorrido com um dos alunos, um dos mais arredios no comportamento social, que em casa, procurou o pai para perguntar onde ele havia conhecido sua mãe e outros detalhes e, posteriormente, compartilhou essa história em sala de aula com os colegas.

Apresentamos a seguir atividades realizadas com esses alunos com base na exploração dos documentos individuais. Essas atividades eram sempre apresentadas e discutidas em Libras e favoreciam a leitura e a escrita em Português. 
Minha História

- Meu nome é nasci no às no Hospital cidade estado

País

- O nome do meu pai é

- O nome da minha mãe é

- O nome dos meus avôs paternos é

- O nome dos meus avôs maternos é

Questionário para ser respondido por duplas de alunos:

1. Quem é o aluno(a) mais velho(a) da classe? Que ano ele(a) nasceu?

2. Quem é o aluno(a) mais novo (a) da classe? Que ano ele(a) nasceu?

3. Que horas o João nasceu?

4. Que estado o José nasceu?

5. Que cidade o Guilherme nasceu?

6. Qual o hospital que a Lívia nasceu?

7 Qual o nome dos avôs paternos da Joana?

8. Qual o nome dos avôs maternos da Sara?

Tabela para organização dos dados obtidos nos documentos

\begin{tabular}{|l|l|l|l|l|}
\hline Nome do Aluno & $\begin{array}{l}\text { Data de } \\
\text { Nascimento }\end{array}$ & $\begin{array}{l}\text { Local de } \\
\text { Nascimento }\end{array}$ & Estado & País \\
\hline & & & & \\
\hline & & & & \\
\hline & & & & \\
\hline & & & & \\
\hline
\end{tabular}

A seguir apresentamos também textos produzidos no contexto das atividades descritas que indicam o envolvimento dos alunos e as possibilidades de explorar os conhecimentos que eles trazem no espaço escolar, criando situações de escrita bastante contextualizadas. 


\section{Texto construído com base na certidão de casamento dos pais de uma aluna ${ }^{3}$. \\ Casamento}

No dia sete de maio de 1983, João de Oliveira e Claudete da Silva se casaram, depois do casamento o nome da noiva mudou para Claudete da Silva Oliveira.

Ele tinha 22 anos trabalhava como prensista, nasceu em Cianorte no estado do Paraná, dia 21 de abril de 1961, seus pais eram José de Oliveira e Joana de Oliveira.

Ela tinha 19 anos não trabalhava, nasceu em Indianópolis no estado do Paraná, dia 22 de outubro de 1963, seus pais eram Maria Silva e Jorge Silva.

Eles tiveram três filhos e a caçula nasceu surda.

Esse texto foi trabalhado com muito entusiasmo pelos alunos, pois puderam saber com que idade os pais se casaram, os nomes dos avôs, o dia do casamento dos pais, e entender que a mulher pode adotar, se quiser, o sobrenome do marido quando se casa. ${ }^{3}$

\section{Texto escrito em conjunto com Instrutora Surda narrando fatos sua histó- ria de vida. \\ Priscila}

A Priscila é a instrutora surda da nossa escola.

Ela é filha de filha de João Batista dos Santos e de Clarisse Aparecida dos Santos.

Priscila nasceu no dia 3 de abril de 1976, em Campinas estado de São Paulo.

Quando Dona Clarisse estava no sétimo mês de gestação descobriu que tinha uma infecção urinaria e precisou tomar remédio para sarar. 0 médico explicou que seu bebê (Priscila) poderia nascer com algum "problema".

Quando a Priscila nasceu ninguém percebeu nada. Quando ela estava com 3 anos sua mãe descobriu que era surda.

Priscila estudou muito desde criança, fez faculdade de Pedagogia e pós em educação especial de surdos.

Hoje ela é uma ótima Professora.

Paralelamente a este trabalho, as atividades de leitura foram sendo incentivadas como base fundamental para que a escrita pudesse emergir. Foram oferecidos aos alunos diversos gêneros textuais (bilhetes, notícias, receitas culinárias, pequenos textos acadêmicos e pequenos livros).

Ao final desse trabalho, pudemos observar que os alunos tiveram um

\footnotetext{
${ }^{3}$ Os nomes presentes nos textos são fictícios.
} 
avanço bastante significativo em relação à leitura e à escrita. Cabe lembrar que a parceria e a identificação com o instrutor surdo foi fundamental, pois quando ele fazia a leitura, de forma geral, os alunos ficavam muito atentos e embasbacados com a agilidade e como essa pessoa surda "tão inteligente" conseguia ler, entender e versar os conceitos da Língua Portuguesa em Língua de Sinais.

Essa identificação com a própria língua e com a pessoa surda que lê para os alunos surdos na língua deles, mostra uma ampliação de possibilidades de ser e fazer que não eram vislumbradas em seus processos escolares anteriores. Os alunos surdos sentem que é possível tornarem-se leitores e escritores, e isso os motiva a enfrentar as inúmeras barreiras que o letramento em uma língua oral-auditiva impõe.

A partir de atividades, como as descritas anteriormente, os alunos começam a se espelhar nos instrutores surdos, que têm nível superior, sabem ler e escrever em Português. Apesar do entusiasmo gerado, os instrutores deixam claro que essa tarefa é bastante árdua para estes aprendizes, mas que, por outro lado, é possível de ser realizada.

Com isso, observamos um interesse maior por parte dos alunos em relação à leitura. Assim, podemos constatar que ao desenvolver esse tipo de atividade, os alunos mostram-se mais concentrados, procuram palavras conhecidas no texto, registram novas palavras no caderno e, assim, se comportam como leitores ativos, ampliando seu conhecimento em Português. Vale ressaltar que esse interesse e ampliação do domínio do Português escrito só é possível pela imersão na Libras, que possibilita a compreensão e elaboração daquilo que é apresentado em Português.

Paralelamente a esse trabalho com "documentos" e outros pequenos textos, escolhemos um livro paradidático sobre cidadania e direitos humanos. 0 livro trata da história de um personagem no seu cotidiano na escola e aborda principalmente o tema "Direitos e Deveres". Esse livro foi escolhido porque a escola tinha uma série de exemplares e, dessa forma, foi possível doar um livro para cada um dos alunos, para que pudessem ler em casa e se prepararem para as aulas.

Em relação a essa última atividade, foi feito um trabalho mais demorado de leitura com tradução para Libras, compreensão de sentidos possíveis e leitura autônoma pelos alunos, buscando informações que eles conseguiam apreender a partir do Português escrito.

A leitura do livro foi realizada em diferentes etapas. Inicialmente,

\footnotetext{
${ }^{4}$ Livro: Prof. Bóris em Zeca, o dono dos direitos, de autoria de Luciana de Almeida, publicado pela Fundação Educar DPASCHOAL, 2009.
} 
cada aluno, tendo seu próprio livro, fez uma leitura silenciosa, sendo que tanto a professora quanto o instrutor surdo realizaram também essa atividade. Em seguida, a parte do texto que foi lida silenciosamente foi escrita na lousa e os alunos, a professora e o instrutor surdo fizeram a leitura com tradução para Libras. Por último, cada aluno foi até a lousa para grifar as palavras que reconhecia em Português, e atribuiu a elas um ou mais sinais, apresentando os significados que conhecia.

\section{Considerações finais}

A partir da elaboração da atividade da leitura do livro assim como da atividade de exploração "documentos", observamos um interesse maior por parte dos alunos em relação à leitura.

Com esse tipo de atividade em sala de aula, os alunos mostramse mais concentrados, procuram as palavras conhecidas nos textos, registram novas palavras no caderno e se comportam como leitores ativos Dessa forma, eles despertam o desejo de buscar sentido no texto escrito, o que, consequentemente, faz com que eles comecem a reconhecer autonomamente várias palavras trabalhadas anteriormente.

Assim, pudemos observar que, desde o início dos trabalhos desta proposta de atendimento bilíngue, o interesse geral desses alunos pela escola e pela aprendizagem ampliou muito.

Ressalta-se que os resultados obtidos com as atividades desenvolvidas com os alunos surdos, as quais descrevemos anteriormente, são encorajadores, especialmente se considerarmos que se trata de jovens que não tiveram oportunidades plenas de desenvolvimento escolar em Libras em sua primeira infância. Contudo, esta experiência revela que ainda muito pode ser feito para favorecer o letramento de estudantes surdos e para uma melhor inclusão social deste grupo.

Ainda neste sentido, afirmamos ser essencial que novas estratégias e metodologias para o ensino da língua escrita, considerando a especificidade linguística dos sujeitos surdos, sejam desenvolvidas e encorajadas. Lembrando que o espaço de sala de aula é o lugar privilegiado para que tais estratégias e metodologias sejam gestadas, e que o professor, em sua tarefa de refletir sobre seu trabalho, é o mais preparado e o mais indicado para gerar novos conhecimentos acerca dessa tarefa. 


\section{Referências}

BRASIL. Lei n.ํㅜ 10.436. Dispõe sobre a Língua Brasileira de Sinais - Libras e dá outras providências. Publicada no Diário Oficial da União em 24/04/2003.

Decreto n. $^{\circ}$ 5.626. Regulamenta a Lei n. ${ }^{\circ}$ 10.436, de 24 de abril de 2002, que dispõe sobre a Língua Brasileira de Sinais - Libras, e o art. 18 da Lei no 10.098, de 19 de dezembro de 2000. Publicada no Diário Oficial da União em 22/12/2005.

GÓES, M. C. R. de. Linguagem, Surdez e Educação. Campinas/ SP: Editora Autores Associados, 1996.

LODI, A. C. B. A leitura como espaço discursivo de construção de sentidos: Oficinas com surdos. 282f. Tese (Doutorado em Linguística Aplicada e Estudos da Linguagem), Pontifícia Universidade Católica de São Paulo, São Paulo. 2004.

LODI, A. C. B. e LACERDA, C. B. F. de. Ensino-aprendizagem do português como segunda língua: um desafio a ser enfrentado. In: LACERDA, C. B. F. e LODI, A. C. B. (Orgs.) Uma Escola Duas Línguas: Escola Inclusiva Bilíngue. 2 ed., Porto Alegre: Editora Mediação. 2010.

SILVA, A. B. P e PEREIRA, M. C. C.. O aluno surdo na escola regular: Imagem e ação do professor. In: (autor) Psicologia: Teoria e Prática, , 19 (2), p. 173-176. 2003.

SVARTHOLM, K. Second Language Learning in the Deaf. In: AHLGREN, I,; HYLTENSTAM, K. (Eds.). Bilingualism in Deaf Education - International Studies on Sign Language and Communication of the Deaf, v. 27. Hamburg: Signum Press, 1994.

WATSON, L.M. The Use of a Developmental Approach to Teaching Writing with two Groups of Young Hearing-Impaired Children. In: Journal of the British Association of Teachers of the Deaf, v. 18, n.․ 1, 18-29, 1994. 


\title{
CAPÍTULO VIII \\ ATENDIMENTO EDUCACIONAL ESPECIAL E 0 \\ ESTUDANTE SURDO: O DESAFIO DA APRENDIZAGEM DA LIBRAS EM DIFERENTES AMBIENTES ${ }^{1}$
}

\author{
Lara Ferreira dos Santos ${ }^{2}$ \\ Cristina Broglia Feitosa de Lacerda ${ }^{3}$
}

O Atendimento Educacional Especializado - AEE reconhece de antemão que a escola com suas características e funcionamento regular não dará conta do atendimento do alunado surdo considerando todas as suas necessidades e que precisará, então, ofertar um atendimento complementar.

Se considerarmos que grande parte dos alunos surdos chega à escola sem domínio de uma língua, que conhece de maneira precária o Português e que tem, em geral, pouco ou nenhum contato com a Língua de Sinais, a grande tarefa do AEE será criar espaço para propiciar a aquisição e a aprendizagem da Língua Brasileira de Sinais - Libras, para esses sujeitos.

A aquisição de uma língua acontece em espaços de convivência com interlocutores usuários de uma língua, com a Libras não acontece de forma diferente. A criança irá aprendê-la na convivência com usuários dessa língua e, neste sentido, o AEE precisa ser conduzido por instrutores/ professores surdos capazes de construir espaços de interlocução nos quais a Libras seja a língua de domínio, criando situações para que alunos surdos conversem entre si e com o interlocutor adulto fluente em Libras, de modo a constituírem-se como usuários dessa língua.

Mas, para tanto, é fundamental que nesse espaço a língua circule de forma natural, ou seja, não se trata de ensinar a Libras, assumindo explicações sobre aspectos gramaticais ou lexicais, como frequentemente se observa nos cursos de Libras. É preciso configurar um ambiente de interlocução, no qual a língua seja necessária para jogar, brincar, se colocar, se expressar,

\footnotetext{
${ }^{1}$ Este capítulo foi publicado anteriormente como parte integrante do Material didático do Curso de Aperfeiçoamento em Atendimento Educacional Especializado para alunos surdos.

2 Doutoranda no Programa de Pós-Graduação em Educação Especial na Universidade Federal de São Carlos (UFSCar) e docente substituta na UFSCar.

3 Doutora em Educação pela Universidade Estadual de Campinas (1996). Atualmente, é professora adjunto da Universidade Federal de São Carlos (UFSCar), no Curso de Licenciatura em Educação Especial e no Programa de Pós-Graduação em Educação Especial (PPGEEs).
} 
perguntar, contar, narrar; criar um ambiente no qual a Libras seja central, e permita a dialogia entre os interlocutores. Assim, neste ambiente a língua estará em funcionamento pela necessidade dos interlocutores e não por exercícios ou treinamentos previamente organizados para 'aprender Libras'. É em um ambiente com essas características que as crianças surdas poderão realmente adquirir/aprender Libras.

\section{A figura do instrutor surdo: desafios profissionais}

O Instrutor Surdo é uma figura recente no contexto educacional; mesmo sendo recente a atuação desse profissional, ele tem se mostrado muito presente nas discussões acerca da inclusão escolar de alunos surdos, sendo foco quando se pensa na aquisição e/ou ensino de Língua de Sinais para pessoas surdas.

Os documentos mais recentes consideram instrutor surdo aquele que tem pleno domínio da língua de sinais para transmiti-la aos seus alunos surdos e ouvintes (BRASIL, 2005). 0 termo instrutor parece remeter-se à tarefa específica do ensino de uma língua, mas seu trabalho não se resume a isso: ele não só ensina crianças surdas a compreenderem o mundo de uma forma peculiar, diferente do olhar dos ouvintes, mas também transmite valores, aspectos culturais, emoções, percepções. Também se mostra representante da língua e da cultura surda no ensino a ouvintes.

A formalização do ensino da Língua de Sinais é bastante recente, pois esta, historicamente, foi pouco reconhecida pela sociedade. A reivindicação por um ensino formal teve início somente quando a legislação - nacional e internacional - em favor da educação bilíngue para surdos começou a surgir e ganhar alguma importância.

Apenas em 2002 a Libras foi reconhecida, e oficializada através da Lei n.o 10.436 (BRASIL, 2002), como meio de comunicação e expressão, como um sistema linguístico de natureza visual-motora com estrutura gramatical própria, oriundo de comunidades de surdos do Brasil.

No momento em que a Libras passa a ser respeitada como uma língua própria de um grupo social nota-se que os surdos adultos podem assumir um papel importante no processo educacional de outros surdos, sobretudo crianças e adolescentes. Essa lei foi regulamentada pelo Decreto n. - 5.626/05 (BRASIL, 2005), que trata do direito das pessoas surdas ao acesso às informações por meio da Libras, o direito a uma Educação Bilíngue, a formação de professores bilíngues e de Libras e de Intérpretes de Libras - ILS, dentre outras providências.

No decreto figuram os profissionais: professor surdo e instrutor 
surdo de Libras - com um capítulo destinado a sua formação, fato que favorece a educação dos surdos e interessa à formação aqui proposta.

Em suma, apesar de ser uma figura ainda insuficientemente presente nos contextos educacionais, o instrutor surdo vem ganhando espaço de atuação em diferentes projetos, especialmente nos Centros de Atendimento à Surdez - CAS, no ensino de Libras no ensino superior e nos demais níveis de ensino, entre outros. No entanto, constata-se, uma interpretação vaga ou indefinida quanto ao escopo dessa atuação, o que indica a necessidade de intensificar o debate sobre seu papel (Gurgel, 2004), atuação e formação.

Para aprofundar tais reflexões recorremos, principalmente, ao estudo desenvolvido por Santos (2007), do qual extraímos depoimentos de uma instrutora surda, atuante em um programa educacional bilíngue de inclusão de alunos surdos em uma rede pública de uma cidade de médio porte do interior do país.

O programa visava incorporar a Libras ao espaço escolar, repensando metodologias e desenvolvendo didáticas apropriadas para esses alunos. A instrutora surda atuava com alunos surdos da primeira etapa do ensino fundamental, no contra turno escolar, em dois encontros semanais com duração de uma hora e meia cada. Seu papel era conduzir esses encontros, propiciando o desenvolvimento linguístico em Libras a partir de uma perspectiva dialógica, criando espaços para que a língua fosse vivenciada em seu funcionamento efetivo.

Os depoimentos reportados visam maior conhecimento de aspectos da atuação e formação de Instrutores Surdos. A, como será chamada a instrutora, tinha 26 anos, ensino médio completo, e apenas há três anos atuava no ensino da Libras. Realizou estágio de observação anterior junto a dois instrutores surdos, e recebeu capacitação de 50 horas para iniciar seu trabalho, a fim de discutir aspectos de sua atuação e dificuldades frequentemente encontradas no espaço educacional.

Desde então, sua formação vinha ocorrendo "em serviço", por meio de reuniões semanais com os pesquisadores que assessoravam a implantação do programa. Nestas, a instrutora narrava suas dificuldades, organizava atividades, compartilhava conquistas, e dúvidas com outros profissionais e instrutores surdos, discutindo aspectos relacionados ao ensino, bem como sobre as diferentes necessidades de aprendizagem de cada grupo. Esses dados são trazidos por julgarmos relevante dar voz a essa instrutora surda na busca de contribuir para a formação de outros profissionais. A entrevista foi realizada em Libras e foi transcrita para o Português para facilitar a leitura. 


\subsection{0 ensino para crianças surdas}

Tem, por exemplo, crianças de 8 e de 13 anos [nos encontros]. É difícil porque o nível de conhecimento da Libras é diferente, as atividades que gostam são diferentes, o jeito que cada um gosta. 0 menor gosta de histórias, o maior gosta de conversar, são diferentes [...] eu percebo as diferenças e planejo atividades de acordo com o que gostam, com o jeito deles. Consigo preparar, mas é difícil. Preciso sempre treinar para evoluir (Relato da instrutora).

A instrutora afirma sua dificuldade em trabalhar com crianças de diferentes idades e níveis de conhecimento em um mesmo ambiente; já que no programa são agrupadas crianças de dois ciclos (I e II) para viabilizar seu atendimento nas "Oficinas de Libras" (nome dado ao Atendimento Educacional Especializado realizado no contra turno escolar).

De acordo com os pressupostos da Abordagem Bilíngue (LODI, 2000), a primeira língua da criança surda deve ser a Língua de Sinais, que precisa ser ensinada o mais precocemente possível a fim de possibilitar um desenvolvimento linguístico adequado. Das crianças citadas, poucas iniciaram sua vida escolar com algum conhecimento da Libras, e outras o fizeram com idade bastante avançada. Cabe a instrutora ensinar de maneira a abranger todo o grupo, com atividades que interessem e despertem suas capacidades linguísticas. Lacerda e Caporali (2001) ressaltam que o ensino deve acontecer de forma contextualizada, propiciando a aprendizagem adequada, de acordo com as idades e interesses de cada grupo.

\subsection{No tocante à formação:}

demorou um ano até eu começar a entender. Eu fui treinando, participava de reuniões com a C. e a AC. [assessoras] em que discutíamos as coisas. Sofri muito, porque eu não sabia nada! Eu nunca havia trabalhado antes, nunca! Era a primeira vez e eu não sabia como trabalhar. Nas reuniões elas me ajudavam, me explicavam como eu devia ensinar os surdos, como preparar as atividades; me ajudavam (Relato da instrutora surda).

Nesse depoimento, fica visível a importância de uma formação adequada ao instrutor surdo. C. e AC., assessoras junto ao programa educacional bilíngue, tiveram um papel fundamental na construção de conhecimento da instrutora em questão, pois ensinaram-lhe os 
fundamentos necessários para uma boa atuação. Lacerda e Caporali (2001) abordam a dificuldade em encontrar instrutores surdos com uma formação adequada já consolidada. Nesse sentido, é necessária uma formação continuada e aprofundada que possibilite ao profissional adquirir uma postura de educador e, portanto, atentar para as características específicas de cada grupo. Apenas a fluência em Libras não é suficiente para formar um bom professor/instrutor; é importante também que esse profissional, cada vez mais, aprofunde seu conhecimento sobre a língua, compreenda seu funcionamento e reflita sobre seus aspectos.

A atuação e formação devem ser prioridade para a inserção do instrutor surdo neste novo ambiente de trabalho, pois o processo educacional do surdo - historicamente - deixou muito a desejar, e sem tais requisitos não é possível oferecer ensino de qualidade a educandos surdos na atualidade. A formação continuada parece ser a melhor maneira de preparar esses profissionais (o número de surdos formados em cursos de nível superior é insuficiente), buscando sempre a reflexão, discussão junto a outros profissionais, estudos, atualizações; assim o instrutor não será "apenas" aquele que tem o domínio da Língua de Sinais para o ensino, mas tornar-se-á um verdadeiro educador, associando seus próprios conhecimentos a uma percepção das necessidades de aprendizagem de seus alunos e adequando sua forma de ensino.

\section{0 Atendimento Educacional Especializado: as "Oficina de Libras" como alternativas de trabalho}

Pode-se dizer, de um modo geral, que as crianças surdas que frequentam a educação infantil e séries iniciais do ensino fundamental - por serem filhas de pais ouvintes e, portanto, por não compartilharem uma língua comum com seus pais (elas não têm acesso ao Português e os familiares não conhecem Libras) - chegam às escolas com poucos conhecimentos culturais/sociais desenvolvidos. Além disso, as poucas que tiveram contato anterior com a Libras o sabem de maneira insuficiente, fato que as coloca numa situação de atraso com relação ao desenvolvimento da linguagem e, consequentemente, em defasagem na apropriação de conhecimentos em geral.

Particularmente, as crianças que frequentam a educação infantil, por serem pequenas como as demais crianças que cursam esse nível de ensino, têm dificuldade em focar a atenção, obedecer a regras, entender aspectos da dinâmica da sala de aula e, assim, a construção de tais aspectos deve 
se dar na e com a própria vivência escolar. Cabe, então, aos profissionais envolvidos levarem essas crianças a desenvolverem-se. Porém, o precário conhecimento de Libras dos alunos faz com que se dispersem e pouco compreendam as propostas escolares, e o professor precisa esforçar-se na tentativa de construir com elas os conceitos almejados a partir das possibilidades que apresentam. Nesse sentido, o trabalho do instrutor surdo é fundamental para a aquisição e desenvolvimento da Libras, que servirá de base para todo o aproveitamento escolar.

No ensino fundamental, apesar da idade e dos conhecimentos das crianças serem diferentes da educação infantil, a realidade não é muito diferente. Como elas não têm um domínio consolidado da Libras, problemas semelhantes são enfrentados, com o agravante de que neste nível de ensino se pretende o letramento em uma segunda língua, no caso o Português, quando na maior parte dos casos a Libras é ainda incipiente.

Neste ponto é fundamental destacar que apenas o espaço do AEE, como ambiente de uso e funcionamento dialógico exclusivo em Libras, é insuficiente. Luciano e Lodi (2009) observaram longitudinalmente atividades realizadas em Oficinas de Libras, tanto na educação infantil como no ensino fundamental, espaço em que esta é a única língua em circulação, e encontraram nas crianças surdas evoluções linguísticas significativas. Os alunos mostraram-se mais abertos a seus colegas, conversam e discutem com os demais em diferentes momentos e, dessa forma, apropriam-se dos conteúdos a partir de sua língua.

No caso acompanhado, o único espaço de uso exclusivo da Libras era nas oficinas - AEE. Como as atividades nesse espaço eram realizadas em menor frequência (apenas $3 \mathrm{hs}$ semanais) que as realizadas em sala de aula, as crianças dispunham de um tempo ínfimo com pares adultos surdos usuários dessa língua. Assim, apesar do desenvolvimento de linguagem observado, não se pode negar que as crianças tiveram um desenvolvimento aquém do esperado (Luciano e Lodi, 2009).

Dessa forma, questiona-se se as restrições linguísticas observadas não estão relacionadas às poucas oportunidades de expressão vivenciadas pelas crianças surdas em Libras na escola, visto que passam a maior parte do tempo em sala de aula, na qual a língua de domínio é sempre o Português. Em sala de aula, ainda que dialoguem com seus pares surdos, deve-se considerar que elas também estão se desenvolvendo em Libras e o único interlocutor fluente nessa língua é o intérprete (nos casos em que esse profissional está presente). Essa vivência pode não propiciar as condições almejadas para inserção/ imersão das crianças na linguagem. 
A resposta/solução a esse questionamento fica na dependência de uma transformação das situações lúdicas e de ensino-aprendizagem desenvolvidas no espaço escolar, de forma a levar as crianças a um maior uso da linguagem e, portanto, a necessidade de ações que possibilitem um maior contato das crianças com a Libras, seja em atividades desenvolvidas em sala de aula, seja no aumento do tempo das Oficinas de Libras (Luciano e Lodi, 2009; Turetta, 2006).

Como trabalhar a Libras no espaço das oficinas - AEE? O que são essas oficinas? Por que são chamadas Oficinas de Libras e não Aulas de Libras?

O termo Oficina de Libras visava diferenciar esse trabalho daquele realizado em sala de aula, bem como as funções de professor e instrutor surdo. Essas Oficinas, portanto, não têm um período de duração prédefinido; acontecem como atividade complementar para alunos surdos ininterruptamente. E, diferentemente do que ocorre em uma sala de aula, o Instrutor Surdo não é o responsável pelo ensino formal; ele é um mediador da linguagem e conhecedor da Língua de Sinais, que vai partilhar seu saber de forma lúdica, buscando a imersão das crianças no universo da Libras.

De acordo com Souza Neto (2005), oficina é o local onde se exerce um ofício, com pessoas que comungam da mesma possibilidade de conhecimentos e habilidades, e onde se deve encontrar a matériaprima para o trabalho que acontecerá. Apropriando-se de tal conceito, as Oficinas de Libras podem ser consideradas o local em que membros de uma mesma comunidade (pessoas surdas), partilhando de seus conhecimentos e habilidades numa mesma língua - Libras -, buscarão no desenvolvimento da linguagem meios para enfrentar o processo de escolarização e de desenvolvimento global. Assim, o termo oficina se mostra mais amplo que o termo aula, e é melhor aplicado para os propósitos desejados.

As oficinas acontecem com o intuito de propiciar o desenvolvimento da linguagem e não apenas o ensino de uma língua. Nelas também ocorre a abordagem de diversos fatores que a Libras traz consigo, como questões relacionadas à identidade e aos aspectos culturais: conhecimentos próprios dessa comunidade. Souza Neto (2005, p. 250) ressalta a função das oficinas, acreditando que:

a realização de um ofício no interior de uma dada oficina cria, dentre outras coisas, uma identidade entre os indivíduos e os objetos que estes manipulam, as ferramentas que manuseiam, os processos com os quais 
interagem. E ainda mais, cria uma identidade entre os indivíduos que são parceiros de rituais comuns, realizadores de um dado ofício e situados no ambiente da mesma oficina.

Em concordância com as palavras desse autor, as oficinas só poderiam ser ministradas por um adulto surdo, cuja função é a de promover a aquisição e o desenvolvimento de linguagem das crianças, por imersão; ou seja, por meio da língua em seu uso, em funcionamento. Isso é feito de forma lúdica e contextualizada, utilizando-se de jogos, brincadeiras, histórias infantis e atividades diversas que atraiam a atenção das crianças. A intenção é promover a fluência em Libras de forma prazerosa, assim como o contato com os pares, e também com um adulto surdo, a fim de que isto seja a base para o aprendizado de outros conhecimentos que circulam no espaço escolar, de acordo com os preceitos da abordagem bilíngue, mas dentro dos limites de uma escola inclusiva.

\section{Atividades nas oficinas de Libras - AEE: Desafios da construção de conhecimentos}

\section{Episódio $1^{4}$}

Este episódio aconteceu com um grupo formado por doze crianças, com idades entre 7 e 12 anos, a instrutora surda, e uma das pesquisadoras autoras deste artigo. A instrutora surda retomou o tema da semana anterior, isto é, a construção da maquete de uma cidade - e nela a construção de uma igreja -, para contextualizar e prosseguir com o assunto. Dessa forma, narrou uma história, utilizando a maquete como apoio para os debates, e focalizou, na ocasião, a praça da cidade.

IS. - FAZER IGREJA, LEMBRAR VOCÊS FAZER? CONVERSAR, LEMBRAR? VOCÊS CONHECER IGREJA, CONHECER VOCÊS. CONHECER? IGREJA CONHECER? (Mostra para Adélia a igreja na maquete) OK.

(Uma das crianças faz um sinal que não é possível ver na vídeo-gravação) IS. - ONTEM? SEMANA ANTES HISTÓRIA EXPLICAR, CONVERSAR, IGREJA. LEMBRAR? CONHECER IGREJA? BOM. HOJE...

Luana - ÁRVORE.

IS. - CERTO! AGORA HISTÓRIA.

(P. chama atenção das crianças para iniciar a história)

${ }^{4}$ Legenda para os episódios: IS. - Instrutora Surda, P. - Pesquisadora e os nomes das crianças surdas 
IS. - AGORA HISTÓRIA VOCÊS OLHAR EU. HISTÓRIA COMEÇAR. AMIGO PASSEAR.

P. - AMIGO QUANTOS?

IS. - MUITOS AMIGO.

P. - MUITOS? VOCÊ FALAR DOIS SEMANA ANTES.

IS. - (Faz gesto positivo com a cabeça) DOIS.

P. - OUTRA VEZ. TER-NÃO, MAS PODER IGUAL SEMANA ANTES.

IS. - DOIS AMIGO PASSEAR PRAÇA.

P. - (Olhando para as crianças) CONHECER PRAÇA?

IS. - CONHECER PRAÇA?

(Algumas crianças respondem que sim, outras que não)

P. - (Olhando para Luís Fábio) VOCÊ FEZ-CARA-DE SABER-NÃO. NÃO? CONHECER PRAÇA? NÃO?

P. - (Para IS.) VOCÊ EXPLICAR.

IS. - LEMBRAR PRAÇA VER ÁRVORE MUITAS? TER CHAFARIZ, TER PÁSSARO, COMER. CONHECER? PÁSSARO VER?

(Muitas crianças fazem muitos sinais ao mesmo tempo)

IS. - CHAFARIZ, PRAÇA.

Diego - ÁRVORE.

João - RUA.

IS. - RUA-EM-VOLTA-DA-PRAÇA TER ÁRVORE, BANCO, DINHEIRO GUARDAR, CAIXA-ELETRÔNICO, SABER? TER MILHO, DAR PÁSSARO. TER IGREJA, VER JÁ? IGREJA ( Mostra a igreja na maquete).

P. - SABER JÁ? SINAL TER PRAÇA, SABER?

IS. - PRAÇA.

P. - TUDO, RUA-EM-VOLTA-DA-PRAÇA, ÁRVORE, PRAÇA, TER BANCO MUITOS, SABER? SABER? CERTO. (Como as crianças fazem sinal positivo com a cabeça, olha para IS.) - CONTINUAR.

IS. - PRAÇA VER ÁRVORE, CHAFARIZ, PÁSSARO MUITO, PESSOA MUITO, VER? ANDAR MUITO?

Percebe-se que a pesquisadora intervém a todo o momento no discurso da instrutora, procurando direcioná-la nos modos de responder para as crianças. Além do fato de ser uma atividade nova, a qual, ambas, não sabiam exatamente como conduzir; a pesquisadora parece pressupor que a instrutora não explicaria de maneira minuciosa, de modo a favorecer a compreensão pelos alunos surdos.

A pesquisadora questiona quantos amigos havia na história, visando a continuidade do enredo inicial que introduziu a construção da maquete. Esse detalhe não tinha grande importância para a instrutora, 
passando-lhe despercebido, por isso a pesquisadora mostra-se preocupada com a contextualização correta, pois a cada semana uma nova parte da história era contada, fazendo uso dos mesmos personagens, com a perspectiva de continuidade. Portanto, o número de amigos presentes na narrativa fazia diferença, pois uma explicação incorreta poderia deixar as crianças confusas posteriormente. Essas intervenções só aconteceram devido à formação da pesquisadora, que era mais experiente no trabalho com crianças com atraso de linguagem e preocupada com aspectos que pudessem colaborar para esse desenvolvimento. Além disso, o seu relacionamento de parceria com a instrutora surda favorecia que ela assumisse esse papel. A cumplicidade entre ambas foi fundamental para a formação da instrutora, o que é visível em seu relato:

a P. começou a trabalhar comigo. Discutíamos muito, ela me ajudou muito, eu aprendi, treinei, me esforcei porque recebia essa ajuda. Foi muito bom. A P. me ajudou e eu aprendi; nos ajudamos mutuamente. Eu passei a perceber a forma como ela agia, que era diferente, e aprendi. Porque ela é ouvinte, mas fluente em Libras, era possível conversar. Eu via a P. preparando as atividades e aprendia observando, conseguia ter mais percepção e aprendi muito.

Porém, apesar das intervenções, não é a pesquisadora quem esclarece as dúvidas das crianças. Ela solicita que a instrutora o faça, havendo uma clara distinção dos papéis de cada uma no contexto da oficina. A instrutora, então, constrói novos sentidos, a partir de exemplos reais, vivências próprias e das crianças, apontando para os objetos que existem na praça principal da cidade em que residem; isso só foi possível porque a instrutora tem conhecimentos de mundo e competência linguística para tal.

Percebe-se que há expansão conceitual, gerada por um único sinal - PRAÇA - que abriu a possibilidade de discussão de outros conceitos e sinais que nunca haviam sido realizados como, por exemplo, CHAFARIZ, e que dispensaram maiores explicações, pois o próprio contexto possibilitou que estes fossem compreendidos. Além disso, houve participação ativa dos alunos como interlocutores, os quais não se mostraram apenas receptivos, mas trouxeram comentários e perguntas que permitiram uma construção partilhada do conhecimento.

Tartuci (2001) relata uma experiência de inclusão de alunos surdos em escola regular, sem a presença de profissionais fluentes em Libras, e aborda a questão da construção de conhecimentos. Segundo a autora, o que se observa em sala de aula são cópias e atividades mecânicas, nas 
quais o professor não exige do aluno produção e criatividade. A autora critica as formas de ensino que vêm sendo realizadas:

A aprendizagem significativa depende fundamentalmente da possibilidade de mediação pedagógica, do compartilhar conhecimentos. No entanto, para se elaborar sentidos e conhecimentos, é necessário que se compartilhe também os recursos expressivos que possibilitam essa mediação pela linguagem (Tartuci, 2001, p. 136).

A presença da instrutora surda possibilita a construção de conhecimentos, uma vez que garante a circulação da Libras nesse ambiente e há, também, uma mediação pedagógica permeada por essa língua. 0 fato é que essas crianças só passaram a ter acesso às atividades em sala de aula e a compreender o tema "cidade", após o início da construção da referida maquete na Oficina de Libras; ou seja, a instrutora teve um papel fundamental no funcionamento escolar, e as atividades que realizou - e a forma como as conduziu - mostraram-se bastante adequadas às finalidades pedagógicas almejadas.

Nota-se, também, que ela recorre à maquete para suas explicações, após a descrição em Libras, como um recurso para confirmar a compreensão por parte das crianças, já que a maquete (ferramenta visual) tem papel central na atividade e é o ponto de partida para cada nova discussão.

\section{Episódio 2}

Dando continuidade ao episódio anterior, e fazendo uso da maquete para abordar o que havia na praça da cidade, a instrutora narrou a seguinte história: Dois amigos, passeando pela praça, observam uma cena de casamento, uma noiva entrando na igreja. Depois disso, os dois amigos seguiriam para suas respectivas casas. A. contextualizou o acontecimento para que nenhuma criança tivesse dúvida a respeito do tema que seria abordado:

IS. - CASAMENTO VER VESTIDO BRANCO BRAÇO-DADO HOMEM ... João - HOMEM SABER? ANDAR JUNTO DOIS...

IS. - ANDAR JUNTO DOIS, CERTO! TER DEPOIS PASSEAR.

Diego - HOMEM ÓCULOS FALAR, LER LIVRO... CASAMENTO?

P. - (chamando Diego) SINAL CERTO HOMEM?

IS.- PADRE.

P. - HOMEM ÓCULOS LER, FALAR. PADRE CERTO?

Diego - HOMEM REZAR? 
P. - CERTO, VERDADE.

IS. - PADRE.

Diego - ÁGUA-BENTA?

P. - SIM, ÁGUA-BENTA, TER BRANCO COLOCAR-NA-BOCA, CERTO!

CONHECER? BOM!

IS. - BOM.

Diego - PÃO?

IS. e P. - PÃO, CERTO!

Diego - PÃO, PÃO, FILA TER.

IS. e P. - FILA TER.

(Alice sinaliza algo, mas só é possível ver o sinal TIA)

P. - CASAMENTO? VOCÊ TER NAMORADO, FUTURO CASAR!

Alice - NADA!

P. - (para IS.) OUTRA VEZ FAZER HISTÓRIA, OUTRA VEZ.

Diego se dirige à instrutora e à pesquisadora e faz a seguinte pergunta: “HOMEM ÓCULOS FALAR, LER LIVRO... CASAMENTO?" Diego, na realidade, não faz uma pergunta, pois este não é um conteúdo que ele desconhece, mas sim, elabora uma estratégia de linguagem para confirmar sua hipótese e, ao mesmo tempo, relatar a própria vivência de uma situação de casamento. Ele demonstra conhecimento acerca do tema, e compartilha com seus colegas, que também se colocam no diálogo. Pesquisadora e instrutora dão continuidade à questão, buscando a troca de experiências, que é um dos objetivos das Oficinas de Libras.

Além disso, o episódio revela aspectos da relação entre instrutora surda e pesquisadora ouvinte no contexto da Oficina; trata-se de uma atuação simultânea, conjunta, complementar. Em nenhum momento os papéis se confundem. A criança recorre à instrutora, percebendo claramente quem conduz as atividades e quem é responsável pelo ensino, e é ela quem responde à questão trazida pelo aluno. Porém, a pesquisadora indica, sempre que necessário, a conduta adequada para uma atuação positiva durante o ensino. A instrutora, por sua vez, aceita as sugestões e não deixa de se colocar no diálogo. Deve-se considerar que sua formação se dá "em serviço", e as intervenções da pesquisadora têm como intuito orientá-la, para que futuramente venha a conduzir autonomamente as atividades.

Portanto, para uma educação que respeite as necessidades das crianças surdas, a união do conhecimento da Libras, pela Instrutora Surda, e do conhecimento teórico/didático da pesquisadora ouvinte mostra-se muito adequada e frutífera. 
A pesquisadora parece se preocupar com a questão lexical, introduzindo alguns sinais que as crianças desconheciam. Embora o ensino lexical não deva ser priorizado nas oficinas, trata-se de um processo natural no ensino da língua e no desenvolvimento da linguagem. As intervenções da pesquisadora, nesse sentido, são necessárias, pois faz parte dos propósitos para a formação da instrutora o fato de direcioná-la a um ensino contextualizado e adequado.

0 aspecto fundamental desse episódio está exatamente na conduta da instrutora e da pesquisadora: a questão levantada pelo aluno conduz a atividade para a construção de conhecimentos, de forma lúdica e dialógica. 0 objetivo das Oficinas é um ensino diferenciado, que permita a imersão das crianças na Libras. Este objetivo foi atingido, de forma bastante efetiva, demonstrando que a formação "em serviço" da instrutora resulta em condutas satisfatórias ao longo de suas atividades.

Dias, Pedroso e Rocha (2003) discutem a importância da presença de educadores surdos no contexto educacional e ressaltam que estes devem ser fluentes em Libras, conhecer a cultura e pertencer à comunidade surda. Entretanto, para as autoras, isso não é suficiente. Elas apontam a necessidade desse profissional ter habilidades para atuar como educador, isto é, que saiba ensinar. Partilhando dessa opinião, acreditamos que seja em programas como o descrito anteriormente, no qual é oferecida formação continuada, que o Instrutor Surdo pode desenvolver melhor suas habilidades/capacidades para atuar como educador.

\section{Episódio 3}

Este episódio ocorre em um contexto diferenciado em relação aos anteriores. Fazendo uso da maquete da cidade, a instrutora narrou uma nova história, propondo, em forma de charada, que as crianças descobrissem o que seria necessário construir. Vejam a seguir:

IS. - COMEÇAR HISTÓRIA. OLHAR EU LÍNGUA-DE-SINAIS, CERTO? MENINO ESCOLA BRINCAR, SINAL OUVIR. COMER, BRINCAR, ANDAR, CAIR. CAIR. CALÇA CALÇA-RASGAR, TRISTE. CHORAR PORQUE CALÇA NOVA CALÇA-RASGAR, PORQUE NOVA. CHEGAR CASA, MÃE: CALÇARASGAR CALÇA NOVA. MÃE MENINO IR CENTRO COMPRAR CALÇA NOVA. ONDE COMPRAR? ONDE?

Juliana - CENTRO.

IS. - CENTRO ONDE?

Luís Fábio - ROUPA. 
(Muitas crianças juntas fazem o sinal de roupa, gritando e sinalizando ao mesmo tempo)

Juliana - PERTO CLÍNICA.

IS. - SINAL ONDE?

(Várias crianças sinalizam ao mesmo tempo)

IS. - SABER MENINO CALÇA-RASGAR, JUNTO MÃE CENTRO COMPRAR NOVA CALÇA, ONDE? ONDE?

(Nenhuma das crianças responde o esperado, todos mostram as roupas)

Diego - ROUPA HOMEM-ARANHA.

IS. - HOMEM-ARANHA NÃO HISTÓRIA. MENINO CALÇA-RASGAR, HISTÓRIA, COMPRAR NOVA IR CENTRO, ONDE? IR PROCURAR COMPRAR CALÇA, ROUPA, ONDE?

Luís Fábio - SABER BLUSA?

IS. - BLUSA VENDER.

Diego - GRAVATA.

Luís Fábio - CASA PERTO.

Juliana - LOJA ENTRAR.

IS. - CERTO! CERTO! (Manda um beijo para Juliana) SINAL LOJA, SINAL LOJA! COMPRAR ROUPA, VOCÊS ENTENDER? COMPRAR CALÇA, MENINO DAR. FELIZ, NOVA CALÇA LOJA COMPRAR.

A instrutora propõe uma "charada", a fim de promover o raciocínio dos alunos, e não simplesmente oferece o sinal e seu conceito; o que demonstra uma atitude madura como educadora, a qual busca a construção do conhecimento por meio da interação dialógica na língua de domínio das crianças.

Em outro turno, a instrutora repete o sinal CAIR, enfatizando o acontecimento. Dessa forma, ela chama a atenção das crianças para o desenvolvimento/continuação de sua narrativa, dando a pista para descobrir o desfecho da história. Se a situação se desse com alunos ouvintes, essa ênfase, possivelmente, se daria pela entonação da voz.

A instrutora utiliza o recurso da repetição com o mesmo objetivo, demonstrando que, embora a Libras e a Língua Portuguesa sejam bastante diferentes, bem como suas estratégias e recursos para compreensão, ambas permitem significar conceitos e enfatizar aquilo que o professor, no caso, deseja destacar. Essa prática dialógica favorece o acesso a aspectos discursivos da língua, ou seja, a instrutora não apenas ensina léxico, mas em suas atitudes vai dando pistas de como dar ênfase na língua e, além disso, chama a atenção para outras marcas que são fundamentais na constituição de um interlocutor fluente em uma língua. 
Inicialmente, as crianças não respondem com o sinal esperado LOJA -, mas demonstram compreensão, pois indicam pontos de referências de lojas, onde costumam fazer compras - CENTRO, PERTO CLÍNICA, CASA PERTO -, e para as próprias roupas, trazendo para a história narrada os próprios conhecimentos.

Diego traz os sinais ROUPA HOMEM-ARANHA, dando indícios de que compreendeu a questão, que se trata de uma loja de roupas, mas a instrutora não percebe essa sutileza, dizendo-lhe que não se trata desse assunto e que ele deveria estar atento à história que ela narrou. Em vez de explorar a narrativa de Diego, A. intervém de forma negativa, não permitindo um diálogo e a consequente expansão do tema apresentado pelo aluno.

Esse fato ilustra como no espaço dialógico os sentidos são alçados ou preteridos, e quanto mais ampla for a formação e atenção daquele que conduz as atividades, maiores são as chances de se ter uma interlocução eficaz. A. mostra atitudes adequadas para abordar as crianças, mas lhe faltam conhecimentos que lhe permitam fazer uso da fala das crianças para dar "ganchos" ao seu trabalho. No discurso abaixo, nota-se que ela percebe essa necessidade de expansão de conhecimento, de crescimento profissional, a fim de aprimorar sua prática:

Eu sonho em ter uma formação, preciso me transformar, me formar para ter capacidade de ensinar. Com um diploma eu tenho liberdade para trabalhar em qualquer lugar. Preciso "ampliar meus horizontes", crescer, "abrir a cabeça”, pesquisar profundamente. Preciso aprender como o surdo pensa, conhecer psicologia também, os sentimentos deles; e também cultura, identidade, de cada um. Eu quero me transformar (Relato de A.)

\section{Episódio 4}

Neste episódio a instrutora havia solicitado que cada um construísse sua própria maquete, com suas respectivas casas e os arredores. Ela pede, então, que cada um conte o que produziu e como é a casa/lugar onde vive.

IS. - OK. (Chama João) VOCÊ!

João - CASA VIDEOGAME.

IS. - DENTRO CASA TER VIDEOGAME ? VIDEOGAME TER?

João - TER. DORMIR, ESCADA DESCER, CAFÉ. GRITAR.

IS. - GRITAR?

João - GRITAR... CARREFOUR...

IS. - PERTO CARREFOUR? LONGE? PERTO CASA ? PERTO? 
João - LONGE CARREFOUR, LONGE, LONGE ... PRÉDIO.

IS. - PRÉDIO PERTO CASA, PRÉDIO?

João - PRÉDIO PERTO, LONGE. CAMINHÃO, COMER MEIO-DIA FEIJÃO,

CAMINHÃO, CASA POLÍCIA MOVIMENTO-DE-CARROS, GRITAR.

IS. - CASA TER CARRO MOVIMENTO-DE-CARROS?

João - RUA CARRO MOVIMENTO-DE-CARROS, BARULHO!

IS. - BARULHO OUVIR?

João - OUVIR NÃO, SURDO!

IS. - SURDO, CERTO.

João - CARRO RÁPIDO RUA. RÁPIDO. PRONTO!

IS. - PERTO CASA O-QUÊ? SURDO?

João - SURDO TER.

IS. - QUEM?

(Luis Fábio levanta a mão para responder por João, mas a Instrutora Surda não permite, e pede que espere)

IS. - (Para Luís Fábio) ESPERAR. (Olha para João)

João - QUATRO: MAMÃE, SURDO EU, MAURÍCIO, RAFAELA. QUATRO.

IS. - QUATRO FAMÍLIA ... VIZINHO PERTO QUEM? AMIGO SEU?

João - MATEUS.

IS. - LEGAL.

João - PERTO CASA, PERTO.

IS. - SUPERMERCADO TER?

João - TER PERTO, RUA-SUBIR PERTO.

IS. - BOM. (Chama a atenção das crianças) VOCÊS PARABÉNS! VOCÊS VIDA CASA SUA CADA CASA, PERTO... VIDA DENTRO CASA LEGAL. AGORA EU MOSTRAR, ATENÇÃO SINALIZAR. VOCÊS OLHAR EU SINALIZAR, FALAR POUCO, DEPOIS VOCÊS PERCEBER ENTENDER SINALIZAR EU. OLHAR EU ... RUA CASA LEGAL. TER AMIGO VIZINHO, PERTO TER SUPERMERCADO, PADARIA, SORVETE PERTO. ENTENDER VOCÊS CASA MEU?

No início desse episódio observa-se que A. intervém diversas vezes no discurso de João, provavelmente porque ele se mostra menos fluente em sua narrativa, e as intervenções dela se revelam adequadas para fazê-lo ampliar seu discurso. A instrutora, por sua vez, ocupa seu turno discursivo e levanta questões relevantes que possibilitam que o fluxo narrativo se instale e que o aluno seja capaz de produzir uma enunciação mais detalhada, mais rica. Sua postura mostra-se bastante diferenciada daquela que se observa nos episódios 1, 2 e 3 ocorridos no semestre anterior, isto é, demonstra maior autonomia, conduz a atividade sozinha, sem a necessidade de intervenções e orientações, assumindo 
adequadamente seu papel de educadora que sabe seus objetivos e como atuar para atingi-los.

No momento em que João menciona barulhos na rua de sua casa, a instrutora procura chamar a atenção para a sua percepção/condição de surdez. Mas de que forma João construiu o conceito de barulho? Talvez pela sua experiência junto a ouvintes, ou pela sua percepção, pelas vibrações, com ou sem uso de próteses auditivas, tenha o levado a formar um conceito sobre barulho. Ao assistir ao episódio, nota-se uma expressão facial negativa de João, o que indica uma experiência um tanto incômoda. A., de forma bastante pertinente, chama-o para a surdez, questionando-o quanto às referências ouvintes que apresenta, uma vez que relata os fatos a partir da perspectiva ouvinte, quando se refere a "ruído".

A intervenção da instrutora leva-o, então, a refletir sobre sua condição. Assim, ele é auxiliado a perceber aquilo que é próprio da surdez, e o que é próprio do grupo ouvinte. A atuação de A. se orienta no sentido do aluno compreender sua condição de surdez, quando faz referência a pares/iguais, para que João pudesse ter um modelo de identificação. Mais que isso: nota-se no discurso da instrutora um diálogo com a sua história de vida, já que ela foi "privada" da convivência com outros surdos e sempre teve o grupo ouvinte como referência:

Depois, um dia eu estava com minha mãe andando e vi pessoas usando língua de sinais; eu tinha uns 17 anos, eles estavam na praça e eu os vi. Fiquei com vontade, queria aprender. Eu os mostrei para minha mãe, perguntei se ela se lembrava dos surdos, eu os conhecia. Eu não conseguia entendê-los; só alguns sinais como "oi", "mãe”, "pai”, sabia pouco. Fiquei olhando, tentando entender, mas era difícil, eu não conseguia, tentei ficar junto deles. Fomos embora e eu fiquei triste [...] Pensei: “Eu sou sozinha [...] eles estão juntos, se comunicam, conversam e eu sozinha com ouvintes [...] eu vejo os ouvintes e não os entendo! Fiquei triste, muito triste."

Suas atitudes demonstram a tentativa de levar as crianças a uma experiência que ela própria nunca teve, mas que sabe ser um aspecto importante para a formação delas.

É possível inferirmos que a presença da instrutora marca aspectos relacionados à surdez, o que permite às crianças fazerem referências a iguais e a diferentes. Além disso, ela não apenas colhe a resposta da criança, mas procura dar significado ao seu depoimento e questioná-la. A instrutora faz indagações do ponto de vista da surdez, auxiliando na construção da identidade dessas crianças, atingido mais esse objetivo 
importante das Oficinas de Libras. Neste aspecto, a instrutora tem seu papel muito bem definido, conforme se observa em seu discurso: "[...] eu acho meu trabalho importante. Porque eu sou surda como as crianças, isso é a cultura própria do surdo, combina. Consigo ensinar os surdos."

Góes (2000, p. 48) afirma que no contexto inclusivo "torna-se fundamental o contraponto dado pela comunidade de surdos, que permite a criança significar-se como surdo e como sujeito que enuncia numa língua efetiva, a qual tem características próprias e configura-se como fonte de identidade".

É possível perceber também, no contexto estudado, a ausência de exemplos e referências coletivas de surdos - sendo as crianças ou a instrutora o modelo de surdez acessível. Certamente, tal fato decorre da ausência de outros profissionais surdos no ambiente escolar, com quem possam trocar experiências e com quem as crianças tenham contato; fato que leva a instrutora surda a assumir uma postura de modelo único da surdez frente a elas.

Gurgel (2004) afirma que o trabalho do instrutor surdo o coloca em uma condição de solidão, devido a essa ausência de colegas com quem possa dialogar sobre seu fazer específico, o que torna sua atuação ainda mais complexa.

\section{Considerações finais}

Esperamos, com a apresentação dos episódios e depoimentos da Instrutora Surda, termos revelado a importância de um Atendimento Educacional Especializado que focalize o desenvolvimento de Libras de alunos surdos, para que possam, efetivamente, constituírem-se como sujeitos de sua aprendizagem.

Para uma ação que contemple as necessidades de tais alunos, é imprescindível que as atividades despertem interesse e propiciem trocas de experiências entre os participantes e entre o professor e o aluno. A atuação da instrutora se modifica no processo de sua formação em serviço, em sua parceria com a pesquisadora e com o trabalho de orientação promovido pelas assessoras do programa, indicando que este trabalho pode ser potencializado pela reflexão e pela ação conjunta dos vários atores interessados no bom andamento de um Atendimento Educacional Especializado.

As atividades realizadas se mostram adequadas, pois permitem o diálogo entre os presentes. 0 uso de maquetes e a construção conjunta da mesma fazem com que as crianças participem do processo de ensino- 
aprendizagem e possibilitam o manejo e a condução da atividade por caminhos que elas próprias determinam, conforme o nível de conhecimento em que se encontram.

As crianças, nesse espaço, deixam de ser receptoras e passam a ser construtoras do saber. Concordamos com Pereira (1989) quando afirma que para uma vivência desejável dessa língua, a criança surda tem de ser exposta, o maior tempo possível, a situações que permitam inseri-la no funcionamento da língua e no fluxo dialógico, interpretando e sendo interpretada.

0 ambiente escolar inclusivo privilegia, inevitavelmente, experiências ouvintes dos alunos. A oportunidade oferecida aos alunos surdos, nas Oficinas de Libras - AEE, de contato entre pares e com um adulto surdo representante de sua cultura, mostra-se fundamental não apenas para a aprendizagem escolar, mas também para um resgate de histórias de vidas, anterior às experiências escolares; o que não é possível em sala de aula. Constata-se que somente aquele que já vivenciou a surdez, em seus aspectos positivos e negativos, pode proporcionar aos alunos surdos uma educação equiparada à oferecida aos alunos ouvintes.

Os episódios mostram a pertinência do trabalho conceitual promovido pela instrutora surda. Tais conceitos favorecem uma participação mais adequada dos alunos surdos nas atividades propostas em sala de aula, pelos professores ouvintes, para o conjunto dos alunos. 0 trabalho nas Oficinas, com a Libras, revela-se fundamental para que as crianças surdas acompanhem o trabalho escolar como um todo. Além disso, vale ressaltar que a solicitação para que esse trabalho fosse desenvolvido na Oficina de Libras partiu dos próprios professores que, por falta de tempo e/ou competência linguística, não poderiam realizar um trabalho suficientemente aprofundado em sala de aula com esses alunos, o que comprova, mais uma vez, a necessidade desse profissional, o instrutor surdo, em ambientes que se pretendem inclusivos. 


\section{Referências}

BRASIL. Decreto n.ํ⒌626. de 22 de dezembro de 2005 Regulamenta a Lei n.ํㅜ 10.436, de 24 de abril de 2002, que dispõe sobre a Língua Brasileira de Sinais - Libras, e o art. 18 da Lei n. ํ 10.098, de 19 de dezembro de 2000. Brasília: Presidência da República, Casa Civil, Subchefia para Assuntos Jurídicos. Publicada no Diário Oficial da União em 22/12/2005.

Lei 10.436. de 24 de abril de 2002 Dispõe sobre a Língua Brasileira de Sinais - Libras e dá outras providências. Brasília: Presidência da República, Casa Civil, Subchefia para Assuntos Jurídicos. Publicada no Diário Oficial da União em $24 / 04 / 2002$.

DIAS, T. R. S.; PEDROSO, C. C. A.; ROCHA, J. Uma análise sobre o ensino de LIBRAS a familiares ouvintes de alunos surdos. Reunião Anual da Associação Nacional de Pesquisa e Educação (ANPEd) 26. GT-15 Educação Especial, Poços de Caldas/MG, 2003.

GÓES, M. C. R. de. Com quem as Crianças Surdas Dialogam em Sinais?. In: LACERDA, C. B. F. de; GÓES, M. C. R. de (orgs.) Surdez: Processos Educativos e Subjetividade. São Paulo: Lovise, 2000. p. 29-49.

GURGEL, T. M. A. O papel do instrutor surdo na promoção da vivência da língua de sinais por crianças surdas. 2004. 90f. Dissertação (Mestrado em Educação) Universidade Metodista de Piracicaba, Piracicaba, 2004.

LACERDA, C. B. F. de; CAPORALI, S. A. O papel do instrutor surdo no ensino de língua de sinais para a comunidade surda e familiares usuários da Clínica-escola de Fonoaudiologia da UNIMEP: focalizando a questão metodológica. Relatório final de pesquisa, FAP/UNIMEP, 2001.

LODI, A. C. B. Educação bilíngue para surdos. In: LACERDA, C. B. F. de; NAKAMURA, H.; LIMA, M. C. (Orgs.) Fonoaudiologia: Surdez e Abordagem Bilíngue. São Paulo: Plexus, 2000. p. 64-83.

LUCIANO, R. T.; LODI A. C. B.. O Desenvolvimento de Linguagem de Crianças Surdas em Língua Brasileira de Sinais. In: LODI, A. C. B.; LACERDA, C. B. F. de (Orgs.). Uma escola, duas línguas: letramento em língua portuguesa e língua de sinais nas etapas iniciais de escolarização. Porto Alegre: Mediação. 2009.

PEREIRA, M. C. C. Interação e construção do sistema gestual em crianças deficientes auditivas, filhas de pais ouvintes. 1989. Tese (Doutorado em Linguística) - Instituto de Estudos de Linguagem, Universidade Estadual de Campinas, São Paulo, 1989.

SANTOS, L. F. dos. $O$ instrutor surdo em uma escola inclusiva bilíngue: sua atuação junto aos alunos surdos no espaço da oficina de LIBRAS. 2007. 89f. Dissertação (Mestrado em Educação) - Universidade Metodista de Piracicaba, Piracicaba, 2007.

SOUSA NETO, M. F. O ofício, a oficina e a profissão: reflexões sobre o lugar social do professor. Cad.Cedes, Campinas, vol.25, n. 66, maio/ago. 2005.p.249-259Disponível em: <http://www.cedes.unicamp. br>. Acesso em: 18 out. 2006. 
TARTUCI, D. A experiência escolar de surdos no ensino escolar regular: condições de interação e construção de conhecimento. 2001. 182f. Dissertação (Mestrado em Educação) - Universidade Metodista de Piracicaba, Piracicaba, 2001.

TURETTA, B. A. R. A criança surda e seus interlocutores num programa de escola inclusiva com abordagem bilíngue. 2006. 90f. Dissertação (Mestrado em Educação) - Universidade Metodista de Piracicaba, Piracicaba, 2006. 


\section{CAPÍTULO IX \\ O ATENDIMENTO EDUCACIONAL ESPECIALIZADO NO PROCESSO DE INCLUSÃO: EXPERIÊNCIAS DE UMA ESCOLA MUNICIPAL}

Nathália Freitas Santos Nunes ${ }^{1}$

Viviane Prado Buiatti ${ }^{2}$

O presente estudo buscou discutir a inclusão escolar das pessoas com deficiência, transtornos globais do desenvolvimento e altas habilidades/ superdotação, revelando as experiências do Atendimento Educacional Especializado - AEE em uma escola municipal de Ituiutaba - MG. Objetivouse com esta pesquisa compreender e apreender o movimento do AEE nessa escola, conhecer a clientela atendida, compreender como se configura o trabalho desta equipe e identificar a visão de professores e gestão sobre essa proposta, levantando suas concepções, estratégias e práticas para o desenvolvimento de competências no trabalho com essa população.

O movimento mundial pela inclusão é uma ação em âmbito político, social e pedagógico, desencadeada em defesa do direito de todos os alunos estarem em conjunto aprendendo e participando (Brasil, 2007).

O tema inclusão passou a fazer parte das discussões na educação, a partir de mudanças promovidas por eventos mundiais. Dentre estes, destaca-se a "Conferência Mundial sobre Educação para Todos: satisfação das necessidades básicas de aprendizagem”, realizada em 1990, em Jomtien na Tailândia. Considerado um marco pela participação de diversos países do mundo, sendo aprovada naquele momento, a Declaração Mundial sobre Educação para Todos.

A Educação Inclusiva constitui um paradigma educacional fundamentado na concepção de direitos humanos, que conjuga igualdade e diferença como valores indissociáveis, e que avança em relação à ideia de equidade formal ao contextualizar as circunstâncias históricas da produção da exclusão dentro e fora da escola (Brasil, 1998).

Com isso, a partir das análises nas legislações, como a Constituição Federal de 1988 (Brasil, 1988) e a Lei de Diretrizes e Bases n.ำ 9394/96 (LDB 1996), verificou-se que ambas garantem a educação como direito

\footnotetext{
${ }^{1}$ Graduada em Pedagogia da Universidade Federal de Uberlândia- Faculdade de Ciências Integradas do Pontal - FACIP/UFU.

${ }^{2}$ Docente da Universidade Federal de Uberlândia- Faculdade de Ciências Integradas do Pontal -FACIP/UFU.
} 
de todos, destacando que os alunos com deficiência devem receber Atendimento Educacional Especializado "preferencialmente na rede regular de ensino".

\section{0 AEE: Conceito e função na escolarização do público da Educação Especial}

Considerando esse respaldo legal e o apelo da mídia nos últimos anos sobre inclusão escolar, as estatísticas oficiais mostram um aumento das matrículas de estudantes com deficiência em escolas da rede pública de ensino. Tendo assim, a publicação do Decreto n. ${ }^{\circ}$ 6.571, de 17 de setembro de 2008, que dispõe sobre o Atendimento Educacional Especializado AEE e que foi revogado pelo Decreto n.․ 7.611 de 17/11/2011.

Esse mesmo Decreto traz:

Art. 1을 0 dever do Estado com a educação das pessoas público-alvo da educação especial será efetivado de acordo com as seguintes diretrizes:

I - garantia de um sistema educacional inclusivo em todos os níveis, sem discriminação e com base na igualdade de oportunidades;

II - aprendizado ao longo de toda a vida;

III - não exclusão do sistema educacional geral sob alegação de deficiência; IV - garantia de ensino fundamental gratuito e compulsório, asseguradas adaptações razoáveis de acordo com as necessidades individuais;

V - oferta de apoio necessário, no âmbito do sistema educacional geral, com vistas a facilitar sua efetiva educação;

VI - adoção de medidas de apoio individualizadas e efetivas, em ambientes que maximizem o desenvolvimento acadêmico e social, de acordo com a meta de inclusão plena;

VII - oferta de educação especial preferencialmente na rede regular de ensino; e

VIII - apoio técnico e financeiro pelo Poder Público às instituições privadas sem fins lucrativos, especializadas e com atuação exclusiva em educação especial (Brasil, 2011, p. 1).

Alguns autores, como Ferreira e Guimarães (2006), defendem que os alunos que frequentam Escolas Especiais deveriam estar no ensino regular. Para elas, o aluno precisa de incentivos que o estimule a desenvolver habilidades e, por isso, não pode estar em um mundo à parte, logo, a escola torna-se o lugar certo para desafiá-lo a conviver e aprender com as diferenças, incluindo-o também socialmente.

Diante desse contexto, os apontamentos e críticas se acentuaram, 
e a partir de 1990 houve um reconhecimento da Educação Inclusiva. Nas palavras de Glat (2007, p. 16)

diz respeito à responsabilidade dos governos e dos sistemas escolares de cada país com a qualificação de todas as crianças e jovens no que se refere aos conteúdos, conceitos, valores e experiências materializados no processo de ensino- aprendizagem escolar, tendo como pressuposto o reconhecimento das diferenças individuais de qualquer origem.

A Declaração de Salamanca é considerada uma das mais importantes referências internacionais no campo da Educação Especial, resultante da Conferência Mundial sobre Necessidades Educacionais Especiais: acesso e acessibilidade, promovida em 1994 pela Organização das Nações Unidas para Educação, Ciência e Cultura - UNESCO e pelo Governo da Espanha e que teve a participação de 100 países e inúmeras organizações internacionais. Segundo esse documento,

as escolas devem acolher todas as crianças, independentemente de suas condições físicas, intelectuais, sociais, emocionais, lingüísticas ou outras. Devem acolher crianças com deficiência e crianças bem dotadas; crianças que vivem nas ruas e que trabalham; crianças de populações distantes ou nômades; crianças de minorias lingüísticas e crianças de grupos ou zonas desfavorecidas ou marginalizadas (UNESCO, 2001, p. 10).

Outros documentos como, por exemplo, a Convenção de Guatemala (1999), deixam claro a impossibilidade de diferenciação com base na deficiência, e as escolas ditas "especiais" não podem intitular-se como "especiais" com ênfase nas deficiências das pessoas que pretende receber. A lei de Diretrizes e bases de 1996 prevê o Atendimento Educacional Especializado e não a escola especial, cujo modelo rompe com o direito à inclusão e dispõe sobre o acesso e permanência na escola básica. Algumas medidas são salientadas nesta legislação, como a eliminação de barreiras arquitetônicas, práticas de ensino adequadas às diferenças, metodologias e recursos diversificados que atendam a todos.

De acordo com Glat e Blanco (2007), a Educação Inclusiva se constitui em uma política oficial do país, respaldada pela legislação e por diretrizes para a educação básica em níveis federal, estadual e municipal de ensino que delibera em consonância à Resolução CNE/ CEB n. $\stackrel{2}{2}$ de 2002: 
Art. 2o: Os sistemas de ensino devem matricular a todos os alunos, cabendo às escolas organizar-se para o atendimento aos educandos com necessidades educacionais especiais, assegurando às condições necessárias para uma educação de qualidade para todos (Brasil, 2002).

Segundo a Lei de Diretrizes e Bases n.o 9394/96, a Educação Especial é uma modalidade de educação escolar, que deve ser oferecida nas escolas regulares, para os alunos com algum tipo de necessidade especial. Nos últimos anos, a educação está passando por inúmeros processos dinâmicos e discussões em torno do processo de inclusão.

Para a LDB n.․ 9394/96, em seu Capítulo v, Art. 58 a Educação Especial, é definida da seguinte forma:

A modalidade de educação escolar, oferecida preferencialmente na rede regular de ensino, para educandos portadores de necessidades especiais. §1ํ Haverá, quando necessário, serviços de apoio especializado, na escola regular, para atender as peculiaridades da clientela de educação especial. §2응 0 atendimento educacional será feito em classes, escolas ou serviços especializados, sempre que, em função das condições específicas dos alunos, não for possível a sua integração nas classes comuns do ensino regular (Brasil, 1996, p. 64).

Contudo, para se pensar em inclusão é necessário ir além de apenas a presença de alunos com deficiência nas escolas regulares. Dialogando com essa ideia, Ferreira e Guimarães (2006, p. 158) trazem que "é preciso compreender como a deficiência é pensada e repensada no ambiente escolar", e que é fundamental saber qual o significado da escola para este aluno e como a escola está se organizando para atendê-lo.

A escola precisa se reestruturar para que haja adaptação curricular, acessibilidade e para que possa se estabelecer um debate a respeito de uma educação que seja de qualidade para todos. Torna-se imperativo a construção de um currículo que seja capaz de elucidar e, principalmente, valorizar as capacidades de todos os alunos, de propiciar a qualificação profissional para o atendimento adequado às necessidades de todos.

Há uma diferença entre integrar e incluir. Colocar o aluno na escola, integrando-o em um espaço do qual ele, anteriormente, foi excluído não é inclusão, mas sim, integração. A inclusão se resume em não deixar que essas crianças sejam excluídas e deixadas à margem da sociedade, não reconhecendo seus direitos enquanto seres humanos. 
Mazzotta (2008, p. 167) traz

Com relação ao papel da escola, historicamente construído, sabemos que o mesmo tem sido cada vez mais diluído e difuso, tornando-se de difícil apreensão, particularmente em relação à educação básica. Quanto à inclusão escolar, há muitos que a interpretam como ação impraticável. Para tantos outros, trata-se de medida a ser imposta a todos, em quaisquer circunstâncias individuais ou institucionais.

Quanto a isso, Mantoan (2003, p. 26) expõe que, "a distinção entre integração e inclusão é um bom começo para esclarecermos o processo de transformação das escolas, de modo que possam acolher, indistintamente, todos os alunos, nos diferentes níveis de ensino".

Esse processo vem tomando força há alguns anos, com o reconhecimento da Educação Inclusiva como diretriz educacional não só no Brasil, mas também em outros países. Compreendeu-se que, independentemente de classe social, cor, cultura ou desenvolvimento, as escolas regulares precisam acolher, atender e adaptar-se às necessidades de seu aluno e não ao contrário, pois são as escolas que devem se modificar para receber o aluno com deficiência.

Documentos como a Declaração deSalamanca de 1994, oficializaram o termo inclusão, no campo educacional, embasados pela Declaração Universal dos Direitos Humanos, de 1948, e estabelecido pela Conferência Mundial sobre Educação para Todos, de 1990.

Segundo Glat (2007, p. 16),

A Educação Inclusiva significa um novo modelo de escola em que é possível o acesso e a permanência de todos os alunos, e onde os mecanismos de seleção e discriminação, até então utilizados, são substituídos por procedimentos de identificação e remoção das barreiras para a aprendizagem.

Para essa autora, a inclusão precisa remodelar a escola que, por vezes, tornou-se excludente, selecionadora e discriminatória. Mesmo sendo garantido por lei, o processo de inserção dos alunos com alguma deficiência nas escolas regulares vem acontecendo, mas de forma lenta, criando uma lacuna nessa prática, que se torna um grande desafio na realidade das escolas públicas brasileiras. Isso ocorre por inúmeros motivos que são discutidos a todo o momento, podendo ser citado, por exemplo, a falta ou precariedade na estrutura física do espaço escolar. 
Acresce frisar, segundo Mantoan (2003, p. 32) que:

Por tudo isso, a inclusão é produto de uma educação plural, democrática e transgressora. Ela provoca uma crise escolar, ou melhor, uma crise de identidade institucional, que, por sua vez, abala a identidade dos professores e faz com que seja ressignificada a identidade do aluno. 0 aluno da escola inclusiva é outro sujeito, que não tem uma identidade fixada em modelos ideais, permanentes, essenciais.

Somente após uma visão escolar nova sobre o processo de inclusão e sua estruturação adequada, de currículo, de educação, de escola, de profissionais será possível receber esses alunos, com qualidade no ensino regular.

Barbosa (2005, p. 56) explicita ainda que

O conceito de inclusão escolar deve ser considerado como um processo de desenvolvimento institucional da escola e sujeito a um movimento contínuo de evolução, que implica em oportunidades de construção, desconstrução e reconstrução, próprio dos processos evolutivos humanos e constitucionais.

Ao reconhecer que as dificuldades enfrentadas nos sistemas de ensino evidenciamanecessidade deconfrontar as práticas discriminatórias, e criar alternativas para superá-las, a Educação Inclusiva passou a assumir o espaço central no debate acerca da sociedade contemporânea e do papel da escola na superação da lógica da exclusão (Brasil, 2007).

Neste sentido, Mantoan (2006, p. 40) revela que

A inclusão é uma inovação que implica um esforço de modernização e reestruturação das condições atuais da maioria de nossas escolas especialmente as de nível básico -, ao assumirem que as dificuldades de alguns alunos não são apenas deles, mas resultam em grande parte do modo como o ensino é ministrado e de como a aprendizagem é concebida e avaliada.

Pode-se perceber, ao entrarmos em algumas escolas, que foram realizadas poucas mudanças para receber alunos com deficiência e, principalmente, para incluí-los neste espaço. Muitas se preocuparam apenas em fazer rampas, comprar alguns materiais de acessibilidade, como cadeira de rodas e alguns jogos para se trabalhar com essas crianças. 
Infelizmente, as escolas, de uma forma geral, ainda não estão preparadas pedagogicamente, e nem mesmo em sua estrutura, para inserir alunos que saem das escolas especiais.

A Educação Especial deve ser uma modalidade escolar que atravessa todos os níveis da educação, colaborando e orientando a Educação Regular em benefício de todos os alunos que participarem deste contexto. Assim, deve-se compreender o AEE como uma proposta pedagógica, que corrobore com os serviços educacionais e caminhe junto com a escola e seus alunos.

Art. 3ำ São objetivos do atendimento educacional especializado:

I - prover condições de acesso, participação e aprendizagem no ensino regular e garantir serviços de apoio especializados de acordo com as necessidades individuais dos estudantes;

II - garantir a transversalidade das ações da educação especial no ensino regular;

III - fomentar o desenvolvimento de recursos didáticos e pedagógicos que eliminem as barreiras no processo de ensino e aprendizagem; e

IV - assegurar condições para a continuidade de estudos nos demais níveis, etapas e modalidades de ensino (Brasil, 2011, s/p).

Este processo complementa a formação dos alunos, devendo ser organizado para suprir suas necessidades. Glat e Blanco (2007) defendem o Atendimento Educacional Especializado dentro da escola com a finalidade de dar suporte aos professores ditos "generalistas" que estão no ensino regular. Estes possuem conhecimento mínimo sobre as diferenças, por isso, no cotidiano escolar necessitam do "especialista" para auxiliar seu trabalho, e realizar, se for o caso, atendimento direto, complementar ao aluno.

Segundo a LDB, em seu Artigo 59, Inciso III:

Os sistemas de ensino assegurarão aos educandos com necessidades especiais, professores com especialização adequada em nível médio ou superior, para atendimento especializado, bem como professores de ensino regular capacitados para a integração desses educandos nas classes comuns (Brasil, 1996, p. 63).

O AEE deve ser ministrado no contraturno, período oposto ao que aluno esteja matriculado, de preferência no mesmo espaço escolar e organizado em horários pré-estabelecidos, pois o aluno precisa ser atendido individualmente, respeitando sua especificidade. Esse atendimento é realizado na Sala de Recursos Multifuncionais - SRMF. Os 
professores devem ser habilitados para a docência e ter formação inicial e específica na Educação Especial, sendo esta inicial ou continuada.

É um atendimento aos alunos, para que estes recebam auxílio e, dessa forma, sejam inseridos no ensino regular.

Art. $2^{\circ} \mathrm{A}$ educação especial deve garantir os serviços de apoio especializado voltado a eliminar as barreiras que possam obstruir o processo de escolarização de estudantes com deficiência, transtornos globais do desenvolvimento e altas habilidades ou superdotação.

$\S 1^{2}$ Para fins deste Decreto, os serviços de que trata o caput serão denominados atendimento educacional especializado, compreendido como o conjunto de atividades, recursos de acessibilidade e pedagógicos organizados institucional e continuamente, prestado das seguintes formas: I - complementar à formação dos estudantes com deficiência, transtornos globais do desenvolvimento, como apoio permanente e limitado no tempo e na frequência dos estudantes às salas de recursos multifuncionais; ou II - suplementar à formação de estudantes com altas habilidades ou superdotação.

$\S 2^{\circ} \mathrm{O}$ atendimento educacional especializado deve integrar a proposta pedagógica da escola, envolver a participação da família para garantir pleno acesso e participação dos estudantes, atender às necessidades específicas das pessoas público-alvo da educação especial, e ser realizado em articulação com as demais políticas públicas (Brasil, 2011, s/p).

No AEE, o professor usará recursos e estratégias que o auxiliarão para ampliar as possibilidades de participação e atuação nas atividades, relações sociais, comunicação e nos espaços escolares em geral.

Assim traz Mantoan (1999, p. 32)

É indispensável que os estabelecimentos de ensino eliminem barreiras arquitetônicas e adotem práticas de ensino adequadas às diferenças dos alunos em geral, oferecendo alternativas que contemplem a diversidade, além de recursos de ensino e equipamentos especializados que atendam a todas as necessidades educacionais dos educandos, com ou sem deficiências, mas sem discriminações.

A Sala de Recursos Multifuncionais - SRMF é um espaço físico localizado nas escolas públicas para se realizar o AEE. Essas salas devem possuir mobiliário, materiais didáticos e pedagógicos, recursos de acessibilidade e equipamentos específicos para o atendimento dos alunos, público-alvo da Educação Especial e que necessitam do AEE. 
A organização e administração deste espaço são de responsabilidade da escola e do professor que ali atua e este deve ter formação para o exercício do magistério de nível básico e conhecimento específico de Educação Especial.

Por isso, o AEE tem um caráter complementar e suplementar, diferenciado das atividades que o aluno realiza na sala de aula, é um espaço da Educação Especial.

Pontes (2008, p. 2) explicita que

O Atendimento Educacional Especializado (ou educação especial) não se constitui em um sistema paralelo de ensino com níveis e etapas próprias. Tal modalidade educacional deve ser entendida como um instrumento, um complemento que deve estar sempre presente na Educação Básica e Superior para os alunos que dela necessitarem, visando á melhoria da qualidade das respostas educativas que a escola pode oferecer e a consequente facilitação do processo de aprendizagem.

Dessa forma, o AEE não pode ser utilizado como aula de reforço, porque seu objetivo não é resgatar aquilo que foi dado na sala de aula, mas um acesso ao conhecimento, de modo que o aluno desenvolva suas potencialidades. O AEE deve fornecer ao aluno instrumentos de intervenção que o auxilie para que se desenvolva tanto na escola como na vida cotidiana.

Segundo as Diretrizes Operacionais da Educação Especial, para o Atendimento Educacional Especializado na Educação Básica (2010, p. 2),

0 professor do AEE deve atuar, como docente, nas atividades de complementação ou suplementação curricular específica, ensinando de forma colaborativa com o aluno para a definição de estratégias pedagógicas que favoreçam o acesso do aluno com necessidades educacionais especiais ao currículo e a sua interação no grupo, pode também promover as condições de inclusão desses alunos em todas as atividades da escola, orientando as famílias para o seu envolvimento e a sua participação no processo educacional, preparar material específico para o uso dos alunos na sala de recursos e orientar a elaboração de material didáticopedagógico que possam ser utilizados pelos alunos nas classes comuns do ensino regular.

Essa aprendizagem deve dispor de alguns procedimentos que são adequados para o desenvolvimento desses alunos no AEE, podendo ser 
citados: a motricidade, integração sensório-motora, desenvolvimento da linguagem, assim como também livros didáticos e paradidáticos impressos em letra ampliada, em Braille, digitais em Libras, livros de histórias virtuais, livros falados; recursos específicos como reglete, punção, soroban, lupa manual, calculadora sonora, caderno de pauta ampliada, mobiliários adaptados e, principalmente, atividades lúdicas.

O AEE deve ser pautado na inclusão desses alunos com deficiência, levando-os a quebrar as barreiras que lhes foram colocadas no decorrer do tempo para relacionar-se com o meio externo, ou seja, para que estes sejam incluídos não só nas escolas e salas de aula regulares, mas também na sociedade de um modo geral.

\section{Metodologia}

Defronte a tudo isso, a pesquisa qualitativa, com observações e entrevistas semiestruturadas, foi realizada em uma escola pública, na cidade de Ituiutaba - MG que possui Sala de Recursos e AEE há um ano e meio, atendendo apenas os alunos que ali estão matriculados.

As entrevistas vieram corroborar com o trabalho, para fazer uma análise daquilo que é teoria e prática nesse espaço. Entendendo também como se deu e como está ocorrendo à implantação do AEE nessa escola, visto que, diante dos fatos e das conversas informais, a escola ainda se encontra em processo de adaptação, tanto para a sala recurso como para a inclusão.

Assim, por meio de conversas informais, observações e entrevistas semiestruturadas, analisou-se como está acontecendo o AEE nesta escola, quais as concepções e práticas dos profissionais envolvidos. Buscouse relacionar a teoria e a prática cotidiana, trazendo também para essa conversa, autores que discutem esse tema, lembrando que todas as entrevistas foram gravadas e transcritas na íntegra, deixando que as professoras em questão respondessem aquilo que realmente sabiam e estavam pensando no momento.

Durante a realização da pesquisa, algumas questões foram colocadas de forma imediata, enquanto outras foram aparecendo no decorrer do trabalho de campo. A necessidade de dar conta dessas questões para encerrar as etapas da pesquisa levou-nos a um trabalho de reflexão dos problemas enfrentados, erros cometidos, escolhas feitas e dificuldades descobertas.

Por isso, Duarte (2002, p. 140) nos traz: 
Dessa forma, os trabalhos constituintes de pesquisa qualitativa, surgem da necessidade de partilhar algumas informações e reflexões acerca do recurso que, apesar dos riscos e dificuldades que impõe, revela-se sempre um empreendimento profundamente instigante, agradável e desafiador.

Assim, o rigor metodológico usado para este artigo foi a pesquisa qualitativa, que requereu observações, anotações, momentos com o sujeito pesquisado e/ou o tema que se apresenta sob a forma de entrevistas semiestruturadas e, principalmente, conhecimento da discussão que foi realizada ao longo do processo, imbricando a teoria com o discurso das participantes da pesquisa.

\section{Análise da Pesquisa}

No primeiro momento da entrevista realizou-se um questionamento sobre alguns dados das entrevistadas, para conhecer quem são as participantes desta pesquisa, e caracterizá-las. Segue abaixo um quadro com estas informações:

Quadro I: Demonstrativo do perfil dos sujeitos do estudo

\begin{tabular}{|c|c|l|l|l|l|c|}
\hline Professora & Sexo & Idade & Formação & Especialização & \multicolumn{1}{|c|}{ Função } & $\begin{array}{c}\text { Tempo de } \\
\text { trabalho } \\
\text { na função }\end{array}$ \\
\hline 1 & F & 44 & Matemática & Supervisão & Professora AEE & 2 anos \\
\hline 2 & F & 31 & Pedagogia & EJA & $\begin{array}{l}\text { Professora Ensino } \\
\text { Fundamental }\end{array}$ & 11 anos \\
\hline 3 & F & 47 & Pedagogia & $\begin{array}{l}\text { Educação } \\
\text { Especial }\end{array}$ & $\begin{array}{l}\text { Coordenadora } \\
\text { AEE }\end{array}$ & 10 anos \\
\hline 4 & F & 42 & Pedagogia & $\begin{array}{l}\text { EJA/Educação } \\
\text { Infantil }\end{array}$ & Vice-Diretora & 10 anos \\
\hline
\end{tabular}

Fonte: Dados obtidos pela pesquisadora responsável nas entrevistas.

De acordo com o quadro acima, todas as professoras entrevistadas possuem formação superior e especialização, sendo estas na área da educação. Sabe-se que a prática pedagógica propicia uma reflexão e atuação mais compromissada e pode promover o desenvolvimento de alunos que, até então, não saberiam acompanhar e se adaptar dentro de uma sala regular, onde não haviam estado ainda.

Pode-se constatar que o tempo de atuação da professora do AEE destoa bastante da quantidade de tempo das outras professoras do ensino regular, da 
gestora e da coordenadora. A primeira tem dois anos de função; entende-se que esse é um período de adaptação, principalmente no que se diz respeito ao trabalho com a inclusão. As outras três profissionais estão há dez e onze anos no cargo, tempo considerado relevante, pois, nestes casos, a adaptação na instituição escolar já foi superada e as profissionais já vivenciaram experiências e desafios no cotidiano escolar provavelmente intensas.

Para realizar as análises, sentiu-se a necessidade de utilizar o depoimento de uma professora da sala de AEE, de uma professora regente da sala regular, que possui alunos que estão no AEE, de uma gestora e da coordenadora do AEE da cidade. Isto porque, achou-se interessante analisar aquilo que é dito pela regente de sala de aula ao falar em atendimento especializado e, principalmente, compreender se, de fato, a sala recurso tem contribuído, para o aprendizado e a inserção desses alunos. Principalmente, desejava-se compreender se a escola e a Secretaria de Educação do Município estão conscientes de seu trabalho e da responsabilidade para com a Educação Inclusiva. Considera-se de fundamental importância que professores e equipe pedagógica trabalhem coletivamente, para elucidarem um trabalho que seja, de fato, significativo tanto para as escolas como para o aluno que ali está inserido.

Para Glat e Nogueira (2002), o sucesso da Educação Inclusiva depende desse diálogo entre os suportes especializados e generalistas, o que inclui a reestruturação da formação inicial e continuada desses profissionais. Os atendimentos educacionais especializados pressupõem a garantia da presença desses alunos na escola, que significa a inclusão social, mas a participação destes do processo de aprendizagem depende da flexibilização, da proposta curricular, e da construção de conhecimentos propriamente dita, para incorporarem os pressupostos da inclusão.

Segundo relato dos educadores, por meio de conversas informais e de observações, a escola está em processo de adaptação, tanto para a sala recurso, que iniciou suas atividades no ano de 2010, como para a inclusão, por ser uma ideia nova que ainda está sendo implantada na escola.

A escola possui uma rampa de acesso, mas não contempla em todo seu espaço físico acessibilidade para qualquer aluno, com deficiência ou não, pois tem muitas escadas e possui dois andares, onde fica a maior parte das salas de aulas. Analisando de um modo geral, a escola não foi pensada em nenhum momento para receber aluno com deficiência ou mesmo para receber alunos da educação infantil. A escola possui alunos de quatro, cinco anos, não sendo adequada para tal público por ter muitas escadas, valas ao seu redor, pedras no chão que se soltam 
e outros problemas estruturais, o que faz com que os alunos a todo o momento se machuquem.

Diante dessas constatações, compreende-se que a escola ainda terá que se adequar para receber alunos com deficiência, visto que não adianta apenas a sala de AEE, faz-se necessário muito mais do que isso.

\subsection{Concepção sobre inclusão}

Todas as entrevistadas concordam que a inclusão está ocorrendo na escola de forma lenta, e que, de alguma maneira, está começando a fazer parte do cotidiano escolar. Acreditam na inclusão, têm consciência de que a escola receberá alunos com deficiência, mas têm a clareza de que há muito a se fazer e pensar para que a inclusão aconteça.

Nenhum aluno atendido no AEE possui deficiência comprovada por laudo médico. Por exemplo, há nesse espaço escolar uma criança com suspeita de baixa visão, entretanto, a mãe ainda não possui um laudo que comprove essa suspeita. Por isso, são atendidos apenas alunos com dificuldade de aprendizagem, como nos foi dito pela professora da sala.

Segundo essa professora,

Nossos alunos aqui, a maioria, por que a gente esta começando agora, tem deficiência intelectual leve, a gente ainda não tem aqui na escola criança com alguma coisa mais específica. Nós estamos recebendo agora criança assim, então eu acredito que a partir do ano que vem aí sim, a gente vai ter mais casos que não seja deficiência intelectual, mas, por enquanto, é dificuldade de aprendizagem e deficiência intelectual.

Avaliando a inclusão na sua escola, a professora do ensino regular relata:

Na minha escola há inclusão, acho que está sendo uma coisa bem nova e está incluindo mesmo, porque a prefeitura está capacitando uma professora, então essa, está ajudando a gente na sala de aula, orientando, está tendo curso mesmo para essas crianças com dificuldade de aprendizagem. Então, eu acho que agora a educação está começando a tomar um rumo diferente.

Para essa professora, a inclusão é uma novidade. Em seu relato percebe-se que a escola está incluindo crianças com dificuldade de aprendizagem, que são aqueles atendidos no AEE, e não alunos com 
algum tipo de deficiência, que não são considerados público da Educação Especial, por consequência do AEE.

Ao analisar a escola, viu-se que, na fala dessa professora, a escola está conseguindo incluir as crianças sem deficiência, sem transtornos globais, com nenhum tipo de problema físico, por isso, fica a dúvida, será que quando essa escola receber crianças com deficiência, ela estará, de fato, preparada, a partir dos cursos que estão recebendo, apenas com a sala de AEE e uma professora que está se aperfeiçoando para atender essas crianças?

Fazendo um breve debate, a professora do AEE acrescenta:

É um processo muito lento de conscientização, a gente enfrenta ainda uma batalha grande, com professores principalmente, mas isso é questão de conscientização e aí a gente tem que dar tempo ao tempo, como é uma coisa mais nova, mais recente então a gente tem que... mas eu acho sim, que agente está conseguindo muita coisa.

Evidencia-se, assim, que há divergências entre os professores sobre o processo de inclusão. Existem alguns que ainda não possuem essa conscientização e, de certa forma, a professora do AEE reclama do seu isolamento porque, muitas vezes, os alunos são encaminhados ao AEE, sendo delegado a esse profissional, exclusivamente, o atendimento. Nesse ínterim, os demais profissionais "cruzam" os braços depositando a responsabilidade somente no especialista.

A inclusão é nova para aqueles que acreditaram que essa discussão seria passageira e sem maiores significados. Mas para aqueles sujeitos que lutaram e buscaram esse ideal, essa nova modalidade de educação é antiga e está fazendo parte de muitas discussões e polêmicas há muitos anos. Entende-se que alguns professores, infelizmente, não a querem e se mostram ainda enraizados em concepções e atitudes.

A coordenadora do AEE na cidade de Ituiutaba traz uma questão que vai muito além da conscientização:

Ainda nos deparamos com muita resistência dos profissionais, eu tenho caso de professor que fala: "eu não aceito esse menino na minha sala" e não aceita e o menino não fica na sala dela, aí tem que trocar, por que simplesmente ela não aceita e não é só uma, são várias, não é pouco não. Para Ituiutaba, em nível municipal, a resistência é muito grande.

Nesse caso, pode até haver a conscientização, mas a resistência ao novo e à mudança talvez se torne um dos empecilhos que impede os 
professores de aceitarem os alunos com deficiência. Ao mesmo tempo em que há resistência, há também o preconceito e a exclusão. 0 aluno que é rejeitado em uma sala de aula, e tem que passar para outra, porque o professor não o aceita, está sendo alvo de discriminação dentro da própria escola, local em que este deveria ser bem recebido e acolhido independentemente de sua condição física e intelectual.

Além disso, os professores devem estar atentos aos alunos que estão na sala de aula, pois as diversidades são mostradas a todo o momento, mas, às vezes, esses professores não conseguem compreender que todos seus alunos são diferentes e necessitam quem sabe, de um trabalho diversificado.

Cabe a ele, a partir de observações criteriosas, ajustar suas intervenções pedagógicas ao processo de aprendizagem dos diferentes alunos, de modo que lhes possibilite um ganho significativo do ponto de vista educacional, afetivo e sociocultural (Prado e Freire, 2001, p. 5).

A escola e também as práticas pedagógicas precisam ser modificadas para atender e incluir os alunos. Não é possível continuar com os mesmos propósitos e práticas e, principalmente, pré-julgamentos a respeito de qualquer discente. A definição sobre a inclusão elaborada pela professora da sala de AEE é a seguinte: "estabelecer a aceitação das diferenças individuais, é valorizar a diversidade humana, é aprender conviver com o diferente, criar oportunidades reais para todos".

Sabe-se que a diferença é inerente a todo ser humano, não há igualdade, há limitações que precisam ser trabalhadas. A respeito disso, Góes (2004) enfatiza que a escola inclusiva surgiu para atender a todos, os excluídos que se encontravam fora da instituição educacional, porém tem mostrado condições precárias que correspondem às mesmas oferecidas para aqueles que já se encontravam nela, pautando-se num ensino igual para todos. Para Miranda (2003, p. 47), "o que deveria acontecer seria a escola efetuar as devidas adaptações com propostas diferenciadas perante a heterogeneidade das deficiências".

\subsection{Avaliações que as professoras fazem do AEE}

Todas as professoras pesquisadas acreditam que o AEE está, de fato, cumprindo seu papel que é de incluir os alunos com deficiência nas salas regulares. Sabe-se que essa inclusão está direcionada aos alunos que esta escola possui, os quais não são deficientes, mas têm dificuldade de aprendizagem. 
Acredita-se que essas professoras estão falando nessa inclusão, porque ainda não receberam, nesse espaço escolar, nenhuma criança com deficiência e/ou não tiveram contato com nenhuma dessas crianças, talvez, por isso, estejam tão convictas que o AEE esteja, de fato, contribuindo. É certo que esse recurso, como se observa, está mesmo auxiliando de forma satisfatória as professoras que dele necessitam, pois as melhoras e contribuições para com os alunos atendidos são visíveis e mostradas por todas as professoras que possuem alunos nessa sala.

Haja vista que a professora do AEE está muito engajada nesse processo e está em formação contínua, participando de cursos oferecidos pela Prefeitura Municipal. Se, no próximo ano, como está sendo cogitado por ela, a escola receber os alunos com deficiências das escolas especiais, ela já se considera preparada para atendê-los.

Tendo como apoio para elucidar seu trabalho na sala de aula, a professora que atua no Ensino Fundamental declara sobre a atuação da professora do AEE:

Eu acredito assim: que a professora do AEE vem desempenhando um papel muito bom na escola, ajudando mesmo a gente e como ela já foi da sala de aula e é da escola, uma pessoa que tem um bom relacionamento com todos os professores, então isso ajuda muito. E porque sempre, ela está interagindo com a equipe da escola, com os professores da sala de aula, ela procura a gente, pra dar informação sobre aquela criança, a gente tem a devolutiva e tem a troca. Então, eu acho que a prefeitura está investindo muito e acredito que vai dar muitos bons resultados. Continuar mesmo, com o trabalho que ela está fazendo e aperfeiçoar mesmo.

Entende-se que alguns professores têm clareza de que o AEE é um auxílio para o aluno, mas as professoras regentes, que estão na sala de aula, devem contribuir com o mesmo, realizando um trabalho diferente, modificando sua aula e sua forma de ensinar. Para essa professora em questão, verificou-se na entrevista e nas observações que sua prática é diferenciada, pois procura atender seus três alunos, que estão no AEE, separadamente, ou seja, ela tem clareza que esses alunos, às vezes, não conseguem acompanhar os outros em alguma atividade, assim, ela realiza uma atividade diferente, com mesmo intuito para que eles não fiquem excluídos da aula.

Para a professora do ensino regular, as atividades devem ser diferenciadas dentro e fora da sala de aula; o atendimento não deve ser realizado somente no $\mathrm{AEE}$, porque a inclusão pressupõe essa 
parceria. Nas palavras dela, "eu acho que tem que ser assim, com atividade diferenciada da sala de aula com lúdico mesmo, com jogos, brincadeiras, assim, pra trabalhar aquela necessidade da criança, o que ela está precisando".

Se o significado do termo "Atendimento Educacional Especializado" for analisado, pode se compreender que o atendimento, significa dar ou prestar atenção, acolher, observar e o termo especializado traz em seu contexto o significado de particular, singular, um trabalho profissional ligado a uma habilidade ou ao interesse particular de cada sujeito.

Assim, Carvalho (2007, p. 67), traz:

Com esses significados podemos considerar o atendimento especializado tanto do ponto de vista de quem o oferece - o profissional que se especializa - como do ponto de vista do sujeito que o recebe e que, como indivíduo, é um ser particular, singular em seus interesses, em suas características pessoais e sociais. Servem como exemplos - no caso dos profissionais - os professores que se especializam para trabalhar em educação infantil; no Ensino Fundamental de primeira a quarta séries; na educação de jovens e adultos ou no atendimento a cegos, surdos, com paralisia cerebral, com autismo [...] E, no caso dos sujeitos que recebem o Atendimento Educacional Especializado eles são os próprios aprendizes, valorizados em suas particularidades.

Sabe-se que o atendimento na sala de AEE precisa ser dinâmico e alternativo, levando o aluno a desvencilhar de suas barreiras. É necessário que o professor o desafie para que possa se desenvolver cada dia mais, por isso é importante que todas as pessoas envolvidas nesse processo tenham clareza do que é o AEE e o que este representa para a escola.

A vice-diretora da escola considera o AEE como sendo, "muito bom, os alunos crescem e desenvolvem com o atendimento diferenciado, ainda precisamos de atendimento com psicólogo, fonoaudiólogo e até neurologista que deveria ter uma equipe para dar suporte ao AEE".

A professora do AEE, a gestora e a coordenadora admitem que seria necessário uma equipe multiprofissional para atender essas crianças, e que elas poderiam estar em uma Unidade de Saúde. A vice-diretora aponta isso, quando fala sobre o despreparo da escola para receber alunos com deficiência, para ela, “a escola não está preparada, porque só possui uma sala de AEE com professor especializado e o município não conta com uma equipe especializada para dar apoio específico à educação, os profissionais são da saúde e tem que atender toda a cidade". 
De acordo com o Decreto n.o 7.611, que dispõe sobre a Educação Especial e o Atendimento Educacional Especializado, considera-se que a escola está fora das normas da legislação. Com relação a esse assunto, o Art. $2^{\circ}$ descreve: "A educação especial deve garantir os serviços de apoio especializado voltado a eliminar as barreiras que possam obstruir o processo de escolarização de estudantes com deficiência, transtornos globais do desenvolvimento e altas habilidades ou superdotação" (Brasil, 2011, s/p).

Ou seja, esse atendimento deve ser oferecido para os alunos com deficiência, em nenhum momento o Decreto considera a dificuldade de aprendizagem como demanda para o AEE. Fica evidente nos relatos que tanto a coordenadora como a professora do AEE possuem a convicção de que o AEE na escola está em discordância com as políticas previstas pelo Decreto.

Compreendeu-se, a partir da análise das entrevistas e por meio das observações, que todas entendem que o AEE oferecido na escola não está em consonância com a legislação, pois não acolhe crianças com deficiência. É o que a professora do ensino regular revela:

O da nossa escola, segundo o que eu já ouvi falar não. Por que o AEE ele é um caso assim, extremo de crianças mesmo, com muita dificuldade de aprendizado. Então assim, na nossa escola a gente ainda não tem esses casos, então como não tem e também o AEE ele não é pra atender só as pessoas da escola, parece que ele atende a comunidade perto também. Só que por enquanto ainda não esta atendendo, esta atendendo só da escola e só esses casos mais simples. Dificuldade de aprendizagem mesmo.

O AEE faz parte da política de inclusão dos alunos com deficiência. Segundo Batista e Mantoan (2007, p. 13), "foi implantado o Atendimento Educacional Especializado com o propósito de promover o atendimento complementar à escola comum e a inclusão efetiva de seus alunos".

Essa inclusão deve ser compreendida. 0 que tem se questionado é o motivo pelo qual a escola, mesmo tendo a sala de AEE montada, não recebeu ainda nenhum aluno com deficiência, e tem garantido esse atendimento apenas para seus alunos com dificuldades para aprender. Com as entrevistas e conversas informais, foi relatado que na escola há pelo menos um caso que corresponde ao que a legislação compreende. Esse caso é de um aluno do terceiro ano com suspeita de baixa visão, mas até hoje a mãe não conseguiu um laudo que comprovasse isso, há apenas suposições geradas pelos médicos. Mesmo assim, escola recebeu a sala de AEE antes de esse aluno ser matriculado. 
A gestora da escola também relatou que, com a falta de alguns profissionais na educação, o aluno precisa se locomover até a Unidade Mista de Saúde da cidade para ser avaliado, como disse:

A avaliação dos alunos é feita por psicólogos ou fono da prefeitura, na Unidade de Saúde e eles tem que esperar às vezes algum tempo para conseguirem alguma vaga e os que têm condição pagam particular e quando é necessário pela APAE que tem uma equipe de profissionais, já que o município não possui uma equipe especializada (TO, psicólogo, fono, etc.)

Nota-se que tudo gira em torno de mudanças que devem ocorrer tanto nas escolas como na sociedade em geral e, para isso, é necessário uma conscientização também daqueles que detém o poder.

\subsection{Prática pedagógica}

Observou-se a prática pedagógica tanto da professora do ensino regular quanto a da professora do AEE. No discurso as duas relataram preocupação com relação ao desenvolvimento de seus alunos, mas averiguou-se que necessitam usar de técnicas diferenciadas, para atender as necessidades de seus alunos.

A professora da sala regular que tem seus três alunos na sala de AEE salienta:

Então, assim, eu não trabalho com eles do mesmo jeito que eu trabalho com as outras crianças, mas separado. Trabalho com recorte de revista, circular palavrinha, que eles mesmos recortam e cola. E trabalho muito com eles, a oralidade, por que nem conversar eles e especialmente um aluno que não conversava. Agora, interage comigo, com outros funcionários da escola, com os colegas. Tem que ser um trabalho diferenciado, com todas essas crianças. Eles já tiveram uma melhora significativa desde o inicio do ano.

Nota-se um esforço da professora para o trabalho com o aluno, mas ao mesmo tempo algumas atividades demonstram exercícios de repetição, colagem e o trabalho com palavras descontextualizadas. Porém, há uma tentativa desta professora realizar atividades em parceria com a professora do AEE, conforme expressa:

Esse ano eu e a professora do AEE fizemos um trabalho junto, trocamos o material de um aluno porque [...]. Acho que esse trabalho tinha que ter sido 
feito com cinco anos, pra quando chegasse esse ano ele já tá bem melhor, por que esse ano ele já conseguiu avançar muito em termos assim, da escrita, sabe? Nós trocamos lápis, pegamos aquele lápis triangular, por que ele não tinha o movimento da pinça, ele pegava no lápis assim (fez gesto). Tinha muita dificuldade, era complicado, aí a professora do AEE adaptou um lápis também pra ele, nesses lápis comum da gente, ela fez tudo de acordo assim, com que ela estudou, com a formação que ela teve. A gente pode ajudar essa criança e está ajudando.

Nesta perspectiva, entende-se que a prática pedagógica quando trabalhada em conjunto, no estudo de cada caso, de fato contribui para o desenvolvimento dos alunos atendidos pelo AEE, que têm como auxílio uma professora que já tem a consciência de que seu trabalho deve ser diversificado devido a demanda de alunos que possui.

0 professor precisa ter uma concepção diferenciada de ensino e de educação, para que sua prática possa determinar os saberes que são elencados como primordiais e que permeiam as diversas situações tanto dentro quanto fora de uma sala de aula. Percebe-se, durante esse processo, a urgência para que os professores façam uma revisão de suas práticas e reflitam sobre as diferenças humanas, e não buscar apenas uma formação continuada que se volte para ensinar a trabalhar e a se relacionar com um determinado tipo de deficiência. Isso não pode continuar acontecendo dentro de uma sociedade que almeja a inclusão.

É fato que não se pode generalizar e conceituar todos os professores como sendo reprodutores de práticas ultrapassadas, mesmo porque com essa pesquisa pode-se analisar que há professores engajados nessa causa e educadores que estão preocupados com o desenvolvimento de seus alunos. Como é o caso da professora do AEE que procura conversar com as professoras, gestão da escola e, principalmente, com os pais que são, às vezes, descompromissados, como ela mesma salienta.

A professora dispõe de vários materiais na sala de recurso para desenvolver a prática pedagógica com seus alunos atendidos. Para ela, o trabalho na sala de AEE precisa envolver a ludicidade e justifica que dentro da sala de aula e no AEE é o momento em que o discente traz à tona suas angústias diante de tudo que é vivido e é possível lhe oferecer um atendimento individualizado.

Dessa forma, no AEE o aluno aprende também brincando, assim como na sala de aula. A professora do AEE traz que: "se o aluno está no $1^{\underline{0}}$ ano e não conhece as letras, utilizo bingo de letras, o alfabeto móvel, 
recorte de revistas (letra, objeto que começa com a letra estudada) jogo da memória, trilha do alfabeto, tudo aquilo que pode contribuir".

$O$ atendimento na sala de AEE precisa ser um complemento para o aluno que dele necessita, e este deve ir ao encontro das necessidades de cada aluno ali atendido. Por isso, a professora tenta elucidar isso de uma forma lúdica e prazerosa para este aluno, apesar de que possui grandes dificuldades na avaliação e diagnóstico, como relatou na entrevista.

\section{Considerações finais}

Falar de inclusão, em nossa sociedade, é um grande desafio, devido a tantas barreiras que separam as escolas regulares dos alunos com deficiência. A primeira barreira, e acredita-se que seja a mais difícil de romper, é o preconceito. A segunda, a estrutura física do espaço escolar. Embora essa barreira não seja tão difícil de ser superada, sabese que os poderes públicos não disponibilizam verbas suficientes para que esta acessibilidade seja uma realidade. Outra barreira que pode ser citada é a falta de conhecimento a respeito dos direitos das pessoas com deficiência por parte dos pais e/ou responsáveis que não lutam pelos direitos de seus filhos, pois, muitas vezes, desconhecem que estes existem; além de inúmeras resistências da equipe profissional da escola regular e, também, da escola especial para o encaminhamento de seus alunos para a escola comum.

Apesar de todas e quaisquer dificuldades, a inclusão está posta e respaldada pelos documentos oficiais, como na Constituição e em toda a legislação analisada neste estudo. A inclusão é um direito de todo cidadão, portanto, a escola pode estar cometendo um crime quando não aceita receber um aluno com deficiência e/ou transtornos globais do desenvolvimento e altas habilidades, bem como qualquer outra criança em idade escolar.

Assim, o AEE é muito importante para ajudar o aluno com deficiência, com transtornos globais do desenvolvimento e altas habilidades a se desenvolver na vida escolar, pessoal, social e favorecer a sua inclusão na escola.

É notável e constante tanto na fala da professora que atua no AEE, como da coordenadora deste serviço, que se faz necessário e rápido a mudança de paradigmas tradicionais e a modificação de currículos para receber esses discentes. Assim, não adianta ter uma sala preparada para o atendimento desses alunos e professores capacitados, se o currículo, a escola de uma forma geral e os professores não aceitam esses alunos. 
A inclusão deve significar um novo paradigma de escola, em que todos os alunos tenham direito ao acesso e permanência neste espaço. Tornando assim, os mecanismos de discriminação e seleção inutilizados, sendo substituídos por todo tipo de procedimento que contemple uma educação de qualidade e aprendizagem para todos aqueles que ali se inserem.

Embora essa escola pesquisada não esteja em consonância com a legislação, no que se refere ao atendimento do AEE, e para esta, como para tantas outras a inclusão é algo novo, nota-se que há por parte da professora do AEE empenho para que os alunos sejam atendidos na sala recurso e para que a escola possa receber e incluir os alunos com deficiência, transtornos globais do desenvolvimento e altas habilidades.

Inclusão deve significar mudança. É tempo de transformar as escolas, os pensamentos e as atitudes de alguns sujeitos e entender que não basta a garantia de direitos expressa nos documentos legais, são necessárias políticas públicas que propiciem acesso, formação docente e viabilize recursos financeiros para tal. 


\section{Referências}

BARBOSA, E. Educação Especial. Inclusão: Revista da educação especial. Ministério da Educação, Secretaria de Educação Especial. v.1, n.1, (out 2005),. Brasília: Secretaria de Educação Especial, 2005. p. 56.

BATISTA, C. M. A.; MANTOAN, M. T. E. Atendimento Educacional Especializado: deficiência mental, São Paulo: Ed. Moderna-Didáticos, 2007.

BRASIL. Declaração Universal dos Direitos Humanos. Adotada e proclamada pela resolução 217 A (III) da Assembleia Geral das Nações Unidas em 10 de dezembro de 1948. UNESCO, Brasília, DF, 1948.

. Constituição (1988). Constituição da República Federativa do Brasil. promulgada em 5 de outubro de 1988. Brasília: Imprensa Oficial, 1988.

. Declaração Mundial sobre Educação para Todos: plano de ação para satisfazer as necessidades básicas de aprendizagem. UNESCO, Jomtiem/Tailândia, 1990.

Ministério da Educação. Lei de Diretrizes e Bases da Educação Nacional, LDB 9.394, de 20 de dezembro de 1996.

Conselho Nacional de Educação. Resolução CNE/CEB $n^{\circ}$ 2, de 11 de setembro de 2001. Institui Diretrizes Nacionais para a Educação Especial na Educação Básica. Brasília, DF, 2001.

Ministério da Educação. Secretaria de Educação Especial. Política Nacional de Educação Especial na Perspectiva da Educação Inclusiva. Brasília: MEC/SEESP, 2008.

Decreto $n^{\circ}$ 7.611, de 17 de novembro de 2011. Dispõe sobre a educação especial, o atendimento educacional especializado e dá outras providências. Brasília, DF, 2011.

CARVALHO, R. E.. Educação inclusiva: com os pingos nos "is". 5 ed. Porto Alegre:Mediação, 2007.

FERREIRA, M. E. C.; GUIMARÃES, M. Educação inclusiva. 1. ed. Rio de Janeiro: DP\&A, 2006.

GARCIA, C. A. A. et al. Inclusão do aluno com dismotria cerebral ontogenética: análise das práticas pedagógicas. Rev. Bras. Ed. Esp. Marília, v. 12, n. 2, p. 169-186, Mai.-Ago. 2006.

GLAT. R. Educação inclusiva: cultura e cotidiano escolar. Rio de Janeiro: 7 Letras, 2007.

GLAT, R.; BLANCO, L. de. M. V. Educação Especial no contexto de uma Educação Inclusiva. In: GLAT, R (Org.). Educação Inclusiva: Cultura e cotidiano escolar. Rio de Janeiro: 7 Letras, 2007.

GÓES, M. C. R. de; LAPLANE, A. L. F. de. (Orgs.) Políticas e Práticas de Educação Inclusiva. Campinas, São Paulo: Autores Associados, 2004. 
GOMES, A.; FERNANDES, A.; BATISTA, C.; SALUSTIANO, D.; MANTOAN, M. T.; FIGUEIREDO, R. Formação Continuada a Distância de Professores para o Atendimento Educacional Especializado Deficiência Mental. In: Atendimento Educacional Especializado: Orientações Gerais e Educação a Distância. Secretaria de Educação Especial. SEESP / SEED / MEC, Brasília, DF, 2007.

LEVINAS, E.. Ética e infinito. Madri: La Balsa de la Medusa, 2000.

LUCK, H.. Concepções e processos democráticos de gestão educacional. Petrópolis, RJ: Vozes, 2009.

MANTOAN, M. T. É. Inclusão escolar: 0 que é? Por quê? Como fazer?. São Paulo: Moderna, 2003.

MANTOAN, M. T. E. Atendimento educacional especializado: aspectos legais e orientações pedagógicas. São Paulo: MEC/SEESP, 2007.

MARTINS, J.. A pesquisa qualitativa. In: Fazenda, I. (Org.) Metodologia da pesquisa educacional. São Paulo: Cortez, 1994. p. 49-58.

MAZZOTTA, M. J. S. Trabalho docente e formação de professores de educação especial. São Paulo: EPU, 1993.

MAZZOTTA, M. J. S. Educação Especial no Brasil: História e Políticas Públicas. 4. ed. São Paulo: Cortez, 2003.

MITTLER, P. Educação Inclusiva: Contextos Sociais. Porto Alegre, Editora Artmed, 2003.

MIRANDA, A. A. B. A prática pedagógica do professor de alunos com deficiência mental. 2003. Tese (Doutorado em Educação) Universidade Metodista de Piracicaba: São Paulo, de, 2003.

PEREIRA, E. M. de A; LIMA, E. F. e PLACCO, V. M. de S. Desafios da formação: o curso de pedagogia frente às proposições da nova LDB. CEPEE, 4, 1996, Águas de São Pedro, IV CEPEE, Águas de São Pedro, Unesp/Pró-Reitoria de Graduação. 1996.

PLAISANCE, E. Ética e inclusão. Cadernos de Pesquisa, v. 40, n. 139, p. 13-43, jan./ abr. 2010.

PRADO, M. E. B. B.; FREIRE, F. M. P. A formação em serviço visando a reconstrução da prática educacional. In: FREIRE, F. M. P. ; VALENTE, A .(Orgs.) Aprendendo para a Vida: os Computadores na Sala de Aula. São Paulo: Cortez, 2001.

QUEIROZ, M. I. P. Relatos orais: do "indizível” ao "dizível”. In: VON SIMSON, O. M. (Org. e Intr.). Experimentos com histórias de vida (Itália-Brasil). São Paulo: Vértice, Editora Revista dos Tribunais, Enciclopédia Aberta de Ciências Sociais, v.5, 1988. p. 68-80.

STAINBACK, S.; STAINBACK, W._Inclusão: Um Guia para Educadores. Porto Alegre: Artes Médicas, 1999.

UNESCO. Declaração de Salamanca e linha de ação sobre necessidades educativas especiais. Brasília, CORDE, 1994. 


\section{CAPÍTULO IX \\ CONTRIBUIÇÕES DO CURSO DE APERFEIÇOAMENTO EM ATENDIMENTO EDUCACIONAL ESPECIALIZADO PARA PESSOAS SURDAS: CONCEPÇÕES DOS CURSISTAS DA TURMA II, DA SEGUNDA EDIÇÃO DO CURSO}

Fernanda Duarte ${ }^{1}$

Viviane Chaves ${ }^{2}$

O presente trabalho apresenta dados de uma pesquisa desenvolvida no Curso de Pedagogia da Faculdade de Ciências Integradas do Pontal da Universidade Federal de Uberlândia - FACIP-UFU, e tem como objetivo analisar as contribuições do Curso de Aperfeiçoamento em Atendimento Educacional Especializado para Pessoas Surdas, segunda edição, realizado no ano de 2011, nessa universidade, em parceria com o Centro Ensino, Pesquisa, Extensão e Atendimento em Educação Especial - CEPAE na formação dos cursistas. O referido curso faz parte do Programa de Formação Continuada de Professores na Educação Especial, e visa atender a proposta de ampliação da formação docente para a inclusão educacional.

No decorrer do Curso de Pedagogia, muitas inquietações surgiram acerca da inclusão escolar, aumentando assim nosso interesse pela temática. No ano de 2011, participamos do Grupo de Estudos e Pesquisas em Políticas e Práticas em Educação Especial - GEPEPES, que tem como objetivo promover pesquisas sobre formação de professores, na perspectiva da Educação Inclusiva. Cursamos também nesse período as disciplinas de "Libras" e "Aprendizagem e Educação Inclusiva". Essas vivências nos incentivaram a pesquisar um pouco mais sobre a temática: formação de professores na perspectiva da Educação Inclusiva.

Considerando esses pressupostos, o presente trabalho tem como objetivo analisar e discutir as possíveis contribuições do Curso de Aperfeiçoamento em Atendimento Educacional Especializado para alunos Surdos, no trabalho pedagógico de professores das escolas públicas brasileiras.

Entre as questões que nortearam, então, nossa pesquisa, podemos citar: OCurso Aperfeiçoamento em Atendimento Educacional Especializado para Pessoas Surdas contribuiu para a formação dos cursistas? Caso

\footnotetext{
${ }^{1}$ Professora da Faculdade de Ciências Humanas do Pontal/UFU (FACIP/UFU).

${ }^{2}$ Graduanda em Pedagogia da FACIP. Orientanda de IC.
} 
positivo em que aspectos? 0 Ambiente Virtual de Aprendizagem - AVA Moodle, o atendimento e os recursos do curso deram suportes necessários para a aprendizagem? Como os sujeitos participantes avaliam esse curso?

Assim, acompanhamos o curso oferecido para professores da rede pública brasileira, denominado Curso de Aperfeiçoamento em Atendimento Educacional Especializado para Pessoas Surdas - Turma II, oferecido na modalidade a distância, no ano de 2011. 0 acompanhamento desse curso reforçou nossa inquietação acerca da formação dos professores que atuam ou que irão atuar com alunos surdos que frequentam as escolas regulares.

A forma de comunicação, interação entre os alunos, professores e tutores, foi caracterizada, exclusivamente no Ambiente Virtual de Aprendizagem - AVA Moodle. Segundo Behar (2006), considera-se AVA como ambiente coletivo que favorece a interação dos sujeitos participantes, sendo este um todo constituído pela plataforma e por todas as relações estabelecidas pelos sujeitos usuários a partir do uso das ferramentas de interação, tendo com foco principal a aprendizagem.

0 presente trabalho fundamenta-se nessa linha de acordo com as orientações e pressupostos da pesquisa qualitativa. Essa decorre de seu ambiente natural, de forma que o pesquisador tem os dados como principal instrumento, tendo assim um contato direto com a situação que está sendo investigada.

Em relação aos procedimentos metodológicos, foi realizada uma pesquisa bibliográfica sobre Educação Inclusiva, Educação de Surdos e Formação de Professores a Distância, com a finalidade de realizar o aprofundamento do referencial teórico que embasará a pesquisa e as posteriores análises dos dados levantados. Sabemos que a pesquisa bibliográfica é uma metodologia orientadora que

possibilita um amplo alcance de informações, além de permitir utilização de dados dispersos em inúmeras publicações, auxiliando também na construção ou na melhor definição do quadro conceitual que envolve o objeto de estudo proposto (Lima; Mioto, 2007, p. 40).

O presente artigo éresultado da analise dos dados de um questionário inicial e final presente na plataforma do Curso de Aperfeiçoamento em Educação Especial e Atendimento Especializado para Alunos Surdos. Está subdividido em três momentos.

0 primeiro deles consiste em discutir alguns pressupostos da Educação Inclusiva e o Atendimento Educacional Especializado para Pessoas Surdas; em seguida, abordamos os limites e possibilidades do 
aluno surdo na perspectiva da Educação Inclusiva. No terceiro momento, analisamos os dados de um questionário aplicado aos alunos no início e no final do Curso de Aperfeiçoamento em Educação Especial e Atendimento Educacional Especializado para Pessoas Surdas - Turma II.

\section{A Educação Inclusiva para pessoas surdas: alguns pressupostos}

A inclusão apresenta-se como uma proposta amplamente discutida para a comunidade escolar. Vivemos em uma sociedade, muitas vezes, preconceituosa diante das diferenças que na mesma existem, mas um fator que há algum tempo vem sendo destacado é a inclusão de alunos com deficiência, transtornos globais do desenvolvimento e altas habilidades/ superdotação nas escolas regulares de ensino, o qual merece destaque a inclusão de alunos surdos em turmas regulares.

Nesse sentido, a inclusão compreende um movimento pela melhoria do ensino, e o passo inicial para que isso de fato aconteça é olhar a educação por outro prisma, considerando que

fundamental que o professor da escola regular seja devidamente capacitado para receber esse novo alunado que está chegando á escola, pois juntar crianças em uma sala de aula não lhes garante ensino, não lhes garante escola cumprindo seu papel, não lhes garante aprendizagem e, portanto não lhes garante desenvolvimento (Padilha, 2004, p. 96).

Acreditamos que o tema inclusão implica incluir valores como o respeito, o reconhecimento da igualdade diante das diferenças, e dos direitos garantidos legalmente.

Embasados nessa reflexão ressalta-se que a Educação Inclusiva, nos últimos anos, vem conquistando um espaço na sociedade, mediante as diversas discussões sobre a mesma. Dentre alguns eventos realizados no intuito de discutir questões referentes à inclusão, destacamos a "Conferência Mundial sobre Educação para Todos: satisfação das necessidades básicas de aprendizagem", que aconteceu em 1990, em Jomtien, Tailândia. 0 mesmo contou com a participação efetiva de diversos países que aprovaram a Declaração Mundial sobre Educação para Todos.

A "Conferência Mundial sobre Necessidades Educacionais Especiais: acesso e qualidade" constituiu-se como um momento de discussões sobre inclusão e ocorreu em 1994, na Espanha, e trouxe como enorme resultado a Declaração de Salamanca, que significou mais um avanço na Educação Inclusiva. Essa declaração anuncia, no entanto, que as escolas regulares 
com orientação inclusiva precisam se constituir como o meio mais eficaz de combate as atitudes discriminatórias.

A Declaração de Salamanca (1994) prevê que os alunos com necessidades educacionais especiais ${ }^{3}$ devem ter acesso à escola regular e possui como principio orientador a seguinte afirmação: "as escolas deveriam acomodar todas as crianças independentemente de suas condições físicas, intelectuais, sociais, emocionais, linguísticas ou outras" (UNESCO, 1994, p. 2).

Entre tantos avanços, faz-se importante destacar que há pouco tempo, em âmbito nacional, a Educação Inclusiva ganhou sustentação com a Política Nacional de Educação Especial na perspectiva da Educação Inclusiva - PNEE. O referido documento que oficializa a PNEE foi elaborado por um grupo de trabalho nomeado pela Portaria n.. 948/2007, entregue ao Ministério da Educação em janeiro do ano de 2008. A referida comissão foi composta por profissionais da Secretaria de Educação Especial/ MEC e por colaboradores (pesquisadores na área de educação) que discutiram e construíram em conjunto as novas diretrizes no sentido de subsidiar as práticas educacionais nas escolas de nosso país.

Essas diretrizes buscam reforçar a organização do sistema inclusivo, tendo com objetivo, garantir o acesso dos alunos com deficiência, transtornos globais do desenvolvimento e altas habilidades/superdotação em turmas regulares e garantindo-lhes o Atendimento Educacional Especializado - AEE.

Entretanto, é notável a constante busca por mudanças às quais englobam a segurança dos direitos que ainda precisam ser inseridos na educação, considerando uma Educação Inclusiva, sendo fomentada numa perspectiva de respeito às diferentes necessidades, sendo que

as escolas devem acolher todas as crianças, independentemente de suas condições físicas, intelectuais, sociais, emocionais, linguísticas ou outras. Devem acolher crianças com deficiência e crianças bem dotadas; crianças que vivem nas ruas e trabalham; crianças de populações distantes ou nômades; crianças de minorias linguísticas, étnicas ou culturais e crianças de outros grupos ou zonas desfavorecidas ou marginalizadas (Carvalho, 1998, p. 17).

\footnotetext{
${ }^{3}$ Atualmente, no Brasil, seguindo orientações da Política Nacional para a Educação Especial na Perspectiva da Educação Inclusiva e documentos legais posteriores, esse grupo de pessoas é denominado pessoas com deficiência, transtornos globais do desenvolvimento e altas habilidades/superdotação.
} 
Mesmo com o respaldo legal, ainda fazemos questionamos tais como: 0 processo de inclusão está de fato acontecendo? Os alunos surdos têm seus direitos reconhecidos? Como acontece de fato a escolarização dessas crianças?

Reconhecemos, no entanto, a partir de nossas vivências nas escolas, por meio de estágios supervisionados no Curso de Pedagogia, que o ambiente escolar não tem sido tão inclusivo assim, pois não se veem valorizados as peculiaridades do aluno surdo. Os professores não conseguem se comunicar com esse aluno, portanto, não conseguem oportunizar situações efetivas de construção de conhecimentos.

Portanto, ainda existem inúmeras barreiras a serem ultrapassadas, sendo evidente que em muitas instituições ainda não acontece a Educação Inclusiva para as crianças surdas de maneira que estejam garantidos todos os seus direitos.

Para Sassaki (1997, p. 41), inclusão é "um processo pelo qual a sociedade se adapta para poder incluir, em seus sistemas sociais gerais, pessoas com necessidade especiais e simultaneamente, estas se prepararam para assumir seus papéis na sociedade". Considerando a reflexão de que todas as crianças têm direito de participação, mesmo diante suas diferenças e desigualdades, é direito de todos terem uma educação efetiva.

Cabe a uma escola inclusiva proporcionar uma educação voltada para todos, em que qualquer aluno com deficiência, transtornos globais do desenvolvimento e altas habilidades/superdotação ou não, tenha direito de aprender, viver, conhecer em um espaço livre de preconceitos, englobando assim a diversidade. Assim, qualquer escola na perspectiva da Educação Inclusiva precisa ser organizada de forma a atender as necessidades dos alunos começando no próprio espaço físico, até o processo de ensino aprendizagem.

Nesse sentido, Mantoan (1997, p. 149) afirma que

o processo de inclusão exige da escola novos recursos de ensino e aprendizagem, concebidos a partir de uma mudança de atitudes dos professores e da própria instituição, reduzindo todo o conservadorismo de suas práticas, em direção de uma educação verdadeiramente interessada em atender ás necessidades de todos os alunos.

Assim, apesar do debate acerca da inclusão escolar ser algo recorrente na área acadêmica e existir uma garantia legal, ainda precisa avançar em termos de políticas educacionais no sentido de promover e 
assegurar o processo de inclusão escolar. Além disso, há evidencias que mesmo apesar do aumento do número de matrículas, faltam condições básicas para assegurar não somente o acesso, mas a permanência com qualidade desses alunos público da educação especial nas escolas comuns (Mendes, 2006).

Mantoan (2003) destaca que não é possível encaixar um novo projeto, como a inclusão escolar, em um projeto já estabelecido. 0 projeto curricular atual necessita, então, que nele estejam inseridas todas as perspectivas, os conteúdos, em busca de uma real inclusão escolar.

Elaborar currículo segundo Glat; Oliveira (2003, p. 9) consiste em

tomar decisões sobre os saberes que serão considerados, valorizados ou transmitidos pela escola. É também decidir quanto à criação, ou não de grupos excluídos e culturas negadas pela escola. A perspectiva multicultural faz com que o currículo se comprometa com o ensino de qualidade e com a perspectiva de acolhimento e respeito ás diversidades.

Dessa forma, com o intuito de refletir em torno dessas questões, analisaremos a seguir algumas considerações sobre a educação de surdos, adentrando as suas especificidades diante o contexto escolar.

\section{Educação de surdos: limites e possibilidades na perspectiva da Educação Inclusiva}

Com base na história da educação de pessoas surdas, é possível observar que por muitos anos predominou-se a Filosofia Oralista como proposta educacional para alunos surdos. Essa filosofia visava a "reabilitação" da criança surda na comunidade de ouvintes, através da imposição da língua oral e de práticas de oralização em que o aluno surdo era forçado a realizar.

Frente a isso Goldfeld (2001, p. 35) aponta que

A criança surda deve, então, submeter-se a um processo de reabilitação que inicia com a estimulação auditiva precoce, ou seja, que consiste em aproveitar os resíduos auditivos que quase a totalidade dos surdos possuem, e possibilitá-las a discriminar os sons que ouvem.

Além do Oralismo, a educação de surdos assistiu também o método de Comunicação Total, surgido em 1968, sendo este um método que contempla uma proposta flexível no uso de meios de comunicação oral e gestual. 
O grande problema do método da Comunicação Total é o de misturar sinais e a Língua Portuguesa, o que levou a uma prática do português sinalizado e o uso de duas modalidades (bimodalismo).

Goldfeld (2001, p. 41) afirma que

A Comunicação Total acredita que o bimodalismo pode minimizar o bloqueio de comunicação que geralmente a criança surda vivência, evitando assim suas consequências para o desenvolvimento da criança possibilitando aos pais ocuparem seus papéis de principais interlocutores de seus filhos.

A prática da Comunicação Total atingiu muitos defensores nas décadas de 1970 e 1980, mas passou a ser criticada por desconsiderar a estrutura própria da língua de sinais (Goldfeld, 2001).

Assim, em 1980, temos a Proposta Bilíngue ganhando espaço na Educação dos Surdos. Para a Proposta Bilíngue o surdo deve conviver com duas línguas e duas culturas: a língua e a cultura da comunidade surda do seu país, juntamente com a língua oral e cultura ouvinte do mesmo. Com isso, essa proposta defende que a língua de sinais seja ensinada, desde a infância, como primeira língua para o surdo, sendo a língua oral oficial do seu país ensinada, como segunda língua.

No entanto, essa prática pedagógica sempre ficou alicerçada nos moldes da Filosofia Oralista, não sendo, dessa forma, reconhecidas e valorizadas a cultura e a identidade do surdo. Nesse sentido Goldfeld (2001, p. 34) aponta que

o oralismo percebe a surdez como uma deficiência que deve ser minimizada pela estimulação auditiva. Essa estimulação possibilitaria a aprendizagem da língua portuguesa e levaria a criança surda a integrar-se na comunidade ouvinte e desenvolver uma personalidade como a de um ouvinte.

Podemos perceber, assim, algumas práticas em busca da construção de uma escola "inclusiva", mais especificamente sobre a educação de surdos. Dessa forma, detectamos que existem avanços em termos de práticas educativas no sentido de favorecer aos alunos surdos a permanência nas escolas regulares.

Sabemos, por meio de nossas vivências, que nas instituições escolares muitos profissionais da educação ainda não têm uma formação inicial e continuada em relação à educação de surdos, o que dificulta para o aluno o reconhecimento aos seus direitos diante suas necessidades. 
Além disso, o domínio de Libras é insuficiente na formação docente da educação de surdos.

Fonseca (1995) acredita que é preciso preparar todos os professores, com urgência, para obtermos sucesso na inclusão por meio de um processo de inserção progressiva, assim eles terão a oportunidade de relacionar-se com diferentes alunos e, consequentemente, em suas diferenças e necessidade individuais.

Assim, é fundamental que as políticas públicas incentivem a participação dos profissionais em formação continuada e permanente, com vistas que os mesmos trabalhem de maneira adequada diante as especificidades dos alunos, dando-lhes condições de desenvolver práticas coerentes com as especificidades dos alunos.

No entanto, ressalta-se que na formação do professor, há necessidade de se trabalhar a importância da compreensão da história do aluno surdo, sua realidade familiar, escolar e social, reconhecendo-os como sujeitos com suas respectivas diferenças, concretizando de modo geral a inclusão a sociedade.

Nessa direção, Skliar (2001, p. 141) destaca que

a escola inclusiva constitui-se num espaço de consenso, de tolerância para com os indivíduos considerados diferentes. A experiência no dia-a-dia, ao lado dos colegas normais, seria vista com elemento de integração. Parece mais importante a convivência com os colegas normais que a aquisição de conhecimento necessário para sua inserção social. Assim, é oferecido o mesmo espaço escolar, a mesma escola para todas as crianças, como se isso fosse suficiente ou o mesmo proporcionasse igualdade de condições de acesso aos saberes.

Assim para que uma escola seja realmente inclusiva, não se trata apenas de inserir o aluno na escola regular, mas propiciar condições a esse aluno de vivenciar ações educativas que atenda suas especificidades.

Nesse sentido, concordamos com Carvalho (2010, p. 30) quando afirma que "não se pode falar de igualdade de oportunidades, consideradas as regiões geográficas do Brasil e, nelas, as zonas urbana e rural", afinal, apenas a matrícula escolar não significa que o aluno terá sua permanência e terminalidade garantidas com qualidade.

Percebemos, por meio desses estudos, que para termos de fato uma Educação Inclusiva, é necessário que tenhamos uma concepção crítica de inclusão e que repensemos importantes mudanças em nossas práticas pedagógicas. 


\section{Análise de dados}

A seguir, apresentaremos os resultados das análises da pesquisa realizada sobre formação de professores de EaD, que participaram do Curso de Formação Continuada "Atendimento Educacional Especializado para Pessoas Surdas" - Turma II, desenvolvido, no ano de 2011, pela Universidade Federal de Uberlândia, em parceria com o Centro Ensino, Pesquisa, Extensão e Atendimento em Educação Especial - CEPAE. Analisamos um questionário aplicado no início do curso e um questionário aplicado ao final do curso, sendo um total de 755 participantes que responderam ambos os instrumentos. Tivemos como propósito analisar limites e possibilidades dessa formação docente na perspectiva da EaD.

A partir da análise da formação acadêmica dos cursistas, percebemos que metade possui especialização, e $41 \%$ possui graduação. Representa uma pequena minoria de $2 \%$ os que possuem mestrado e $7 \%$ os que possuem apenas nível médio.

Gráfico 1: Formação Acadêmica dos participantes do Curso de Formação Continuada "Atendimento Educacional Especializado para Pessoas Surdas"Turma II.

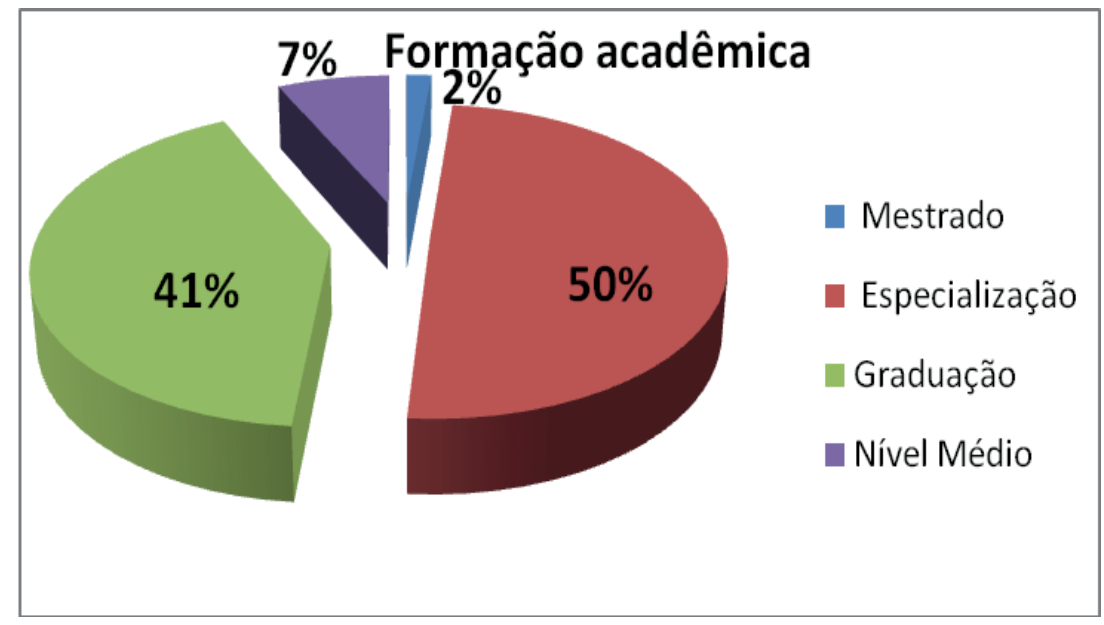

Fonte: Pesquisa de Campo

Sobre as possíveis contribuições do curso, encontramos os seguintes resultados: verificamos que $85 \%$ dos participantes, afirmaram que tiveram suporte oferecido pelo tutor em relação as suas dúvidas e dificuldades. 
Gráfico 2: Demonstrativo quanto ao suporte oferecido pelo Curso de Formação Continuada "Atendimento Educacional Especializado para Pessoas Surdas"Turma II

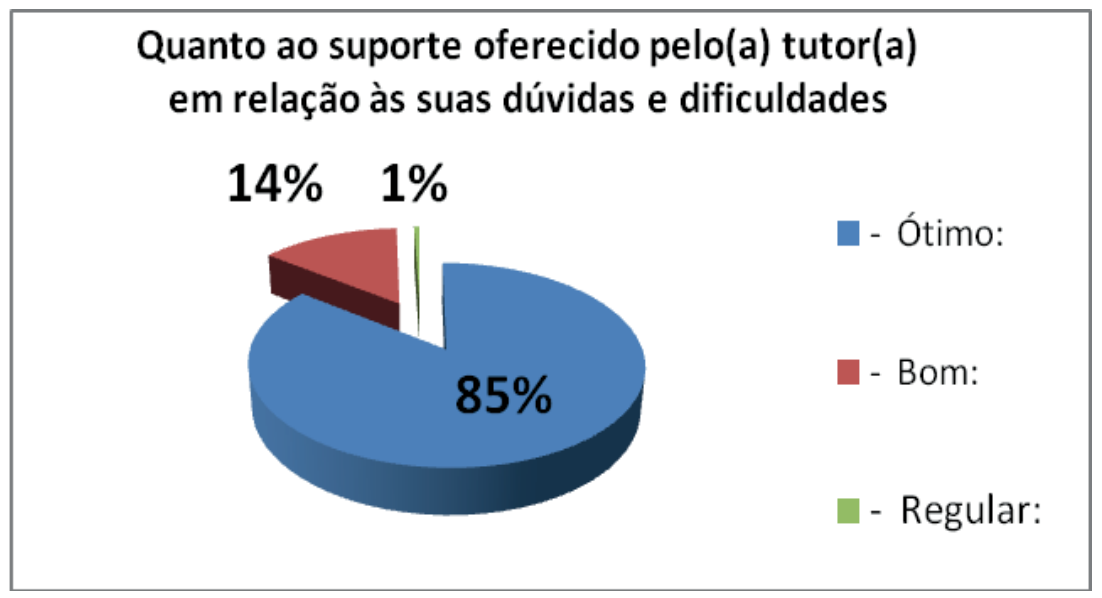

Fonte: Pesquisa de Campo

Nessa linha, Demo (2000) destaca que a distância não é empecilho fatal para a presença, pois é viável estar presente à distância, do que segue que é perfeitamente factível estudar, pesquisar, aprender, conhecer à distância. Esse processo oferece uma interação entre o tutor e o aluno, dando condições de estarem sempre esclarecendo suas dúvidas e construindo conhecimentos sobre o Atendimento Educacional Especializado. Percebemos assim que no curso pesquisado essas interações entre aluno e tutor foram realmente vivenciadas.

Outro dado apresentado é quanto ao acompanhamento/feedback do tutor no desenvolvimento das atividades. 
Gráfico 3: Demonstrativo do acompanhamento do tutor do Curso de Formação Continuada "Atendimento Educacional Especializado para Pessoas Surdas" Turma II

\section{Quanto ao feedback do tutor(a) no desenvolvimento das atividades em cada}

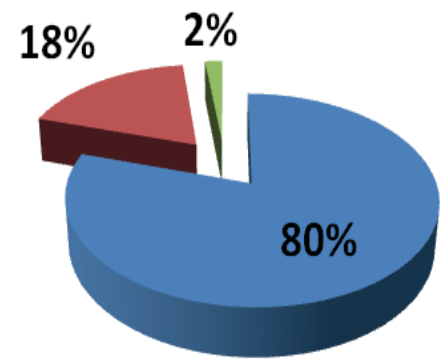

- Ótimo:

- Bom:

- Regular:

Fonte: Pesquisa de Campo

Os dados mostram que a maioria, 80\% dos participantes, destacou que o tutor responsável por sua turma em EaD, acompanhou o desenvolvimento das atividades. Convém destacar que na EaD o aluno tem sempre um contato virtual com o tutor, no qual o mesmo pode fundamentar as atividades, construindo a autonomia de aprofundar nas atividades disponibilizadas pelo tutor.

0 tutor é um educador à distância. Aquele que coordena a seleção de conteúdos, que discute as estratégias de aprendizagem, que suscita a criação de percursos acadêmicos, que problematiza o conhecimento, que estabelece o diálogo com o aluno, que media problemas de aprendizagem, sugere, instiga, acolhe (Maggio, 2001, p. 3).

Assim, o aluno é corresponsável pela busca de conhecimentos, no qual tem condições de construir e reconstruí-los, e não simplesmente reproduzir conceitos trabalhados. 0 tutor tem como função orientar o aluno no desenvolvimento das atividades, e auxiliá-lo a resolver os problemas encontrados durante o curso.

Sobre a linguagem utilizada na EaD, podemos verificar no gráfico abaixo que $84 \%$ dos cursistas ressaltaram que a linguagem é clara e acessível, ou seja, a interação é constituída por uma linguagem de fácil compreensão. Salienta-se a importância da comunicação na EaD, dessa 
forma, o tutor precisa utilizar uma linguagem clara, acadêmica e objetiva ao se comunicar com os alunos, demonstrando respeito intelectual diante a formação do aluno.

Neste sentido, é preciso formar o aluno para comunicar-se adequadamente no AVA, buscando a construção de um ambiente de aprendizagem virtual, caloroso e, principalmente, rico de aprendizagem.

Gráfico 4: Demonstrativo quanto à qualidade da linguagem utilizada no Curso de Formação Continuada "Atendimento Educacional Especializado para Pessoas Surdas"- Turma II

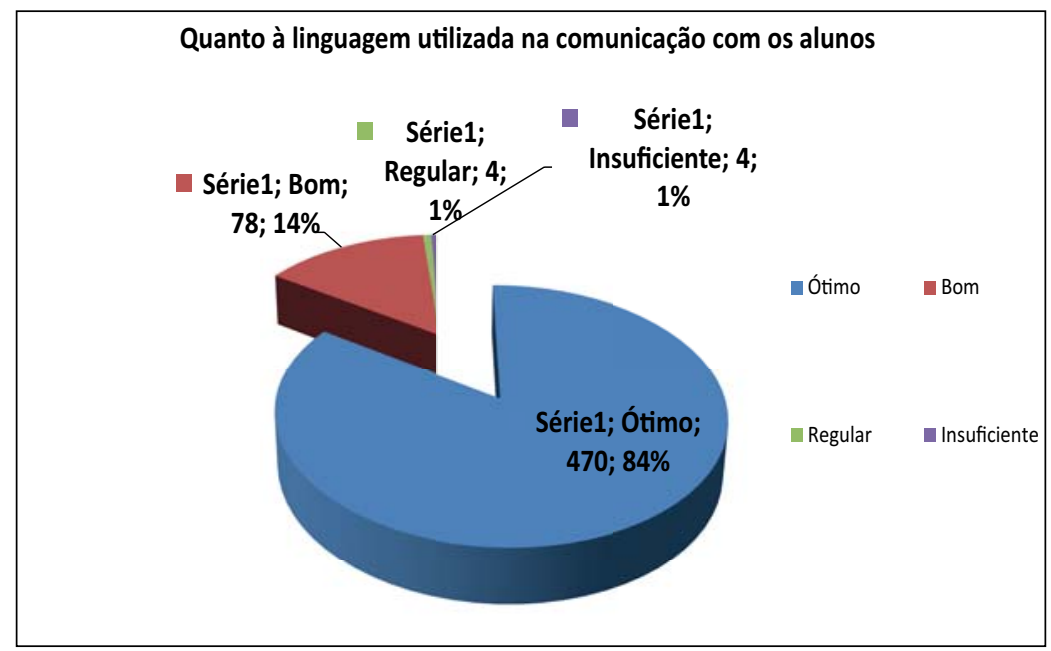

Fonte: Pesquisa de Campo

Sobre questões de relacionamento, o gráfico a seguir mostra que $82 \%$ dos cursistas aprovaram o envolvimento afetivo do tutor com a turma, evidenciando que esse tipo de envolvimento durante a aprendizagem é de suma importância. Dessa forma, o tutor deixa o aluno à vontade para enfrentar os desafios, aumentando a sua própria autoestima, sua autoconfiança, descobrindo, assim, as suas potencialidades no processo de aprendizagem.

Sabemos da importância de existir uma relação afetiva entre o tutor e o aluno, pois mesmo sendo um processo de ensino/aprendizagem que acontece por meio do EaD, a atenção sempre acontece de forma positiva, em que os retornos necessários devem acontecer com agilidade. Dessa forma, o tutor interage de maneira que as trocas de informações com ele e com os demais alunos acabam por valorizar o processo de aprendizagem do aluno, estabelecendo assim uma rede de aprendizes. 
Gráfico 5: Demonstrativo do envolvimento acadêmico e afetivo do tutor do Curso de Formação Continuada "Atendimento Educacional Especializado para Pessoas Surdas"- Turma II

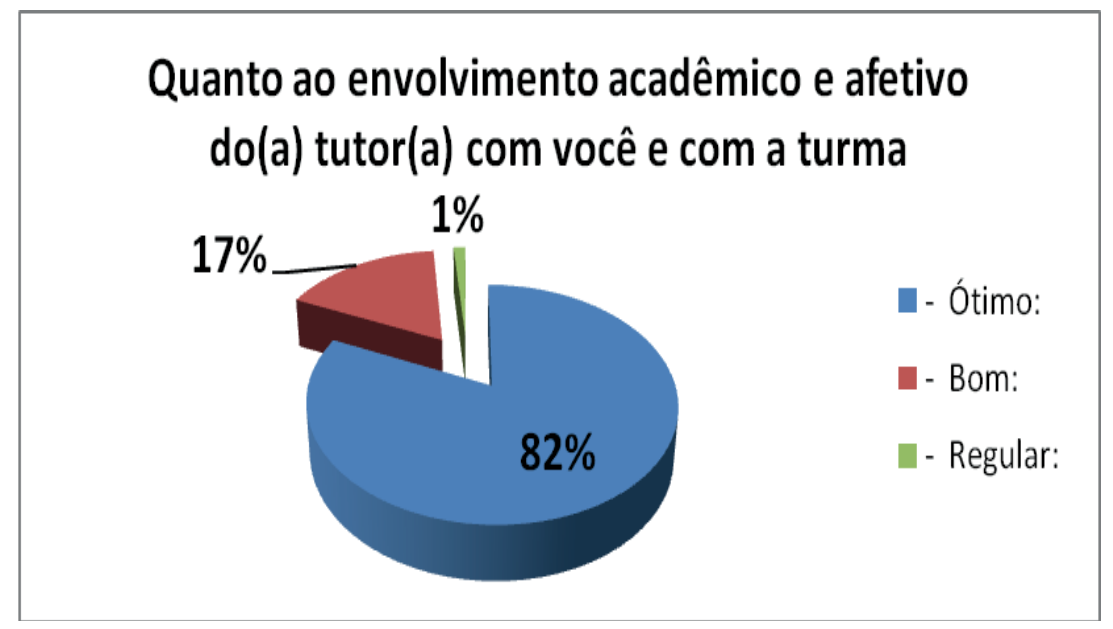

Fonte: Pesquisa de Campo

Verificamos no gráfico a seguir que, com relação à preferência de modalidade de cursos, $87 \%$ dos cursistas preferem a EaD, como melhor modalidade.

Sobre isso Demo (2000, p. 109) destaca que:

a Educação a Distância, poderia socorrer melhor esta demanda infinita, à medida que todos podem participar de alguma forma, sem com isto encobrir as dificuldades de acesso por parte dos mais pobres e das regiões menos desenvolvidas.

Percebemos, assim, que a EaD, constitui-se como uma modalidade que exige comunicação e interação por parte de todos os envolvidos, proporcionando oportunidades de reflexões diante a formação a distância, estimulando a criticidade e a criatividade dos mesmos sem a exigência da presença física diariamente. Portanto, detectamos que essa modalidade vem ganhando espaço, podendo proporcionar um conhecimento significativo para todos os envolvidos no processo. 
Gráfico 6: Demonstrativo quanto à preferência entre as modalidades de ensino presencial e a distância pelos participantes do Curso de Formação Continuada "Atendimento Educacional Especializado para Pessoas Surdas"- Turma II

\section{Modalidade de curso que você prefere}

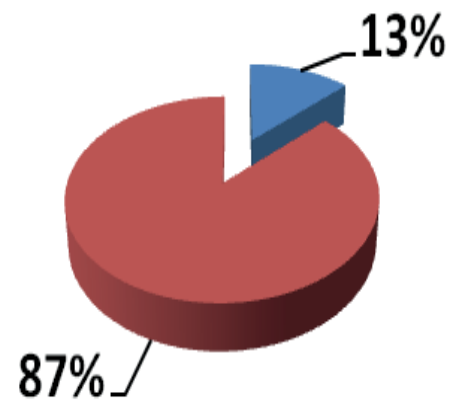

- presencial:

- a distância:

Fonte: Pesquisa de Campo

Outra amostra analisada refere-se ao questionamento se os cursos de formação continuada na modalidade EaD, de fato, contribuíram para a prática do professor.

Gráfico 7: Demonstrativo sobre as contribuições dos cursos de formação continuada na modalidade de EaD emitida pelos participantes do Curso de Formação Continuada "Atendimento Educacional Especializado para Pessoas Surdas" - Turma II

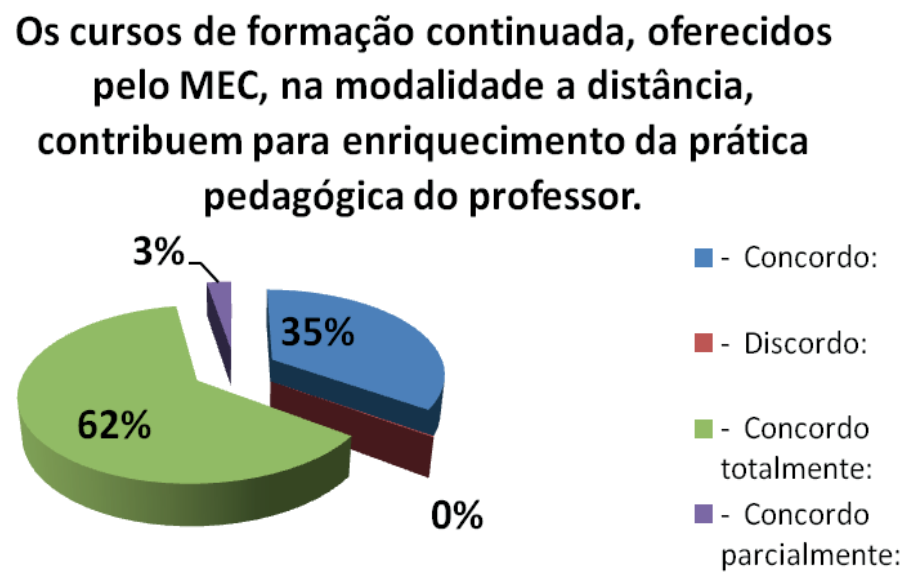

Fonte: Pesquisa de Campo 
De acordo com o Gráfico 7, 62\% dos cursistas aprovam que os cursos oferecidos pelo MEC, na modalidade a distância, contribuem para a prática pedagógica do professor. Acreditamos assim que os cursos que os sujeitos pesquisados vivenciaram, em sua maioria, contribuíram para suas formações.

Considerando a importância dos cursos oferecidos pelo MEC, dados complementares dos questionários analisados demonstram que $100 \%$ dos cursistas concordam que os cursos oferecidos pelo MEC na modalidade a distância são importantes para a formação continuada dos mesmos. Esses dados foram analisados, levando em conta que muitos profissionais não têm possibilidades de participar de outros cursos, em decorrência de suas excessivas cargas horárias presenciais nas escolas. Assim, achamos importante que todos os profissionais aproveitem as oportunidades proporcionadas por órgãos, como o MEC, e busquem conhecimentos para aperfeiçoarem suas práticas pedagógicas.

Outro dado importante é com relação à formação continuada, e as questões relativas à jornada de trabalho e vantagens salariais. Assim, a amostra utilizada apresenta os seguintes resultados:

Gráfico 8: Demonstrativo quanto ao apoio da escola, para que seus professores realizem os cursos de formação continuada, na perspectiva dos participantes do Curso de Formação Continuada "Atendimento Educacional Especializado para Pessoas Surdas" - Turma II

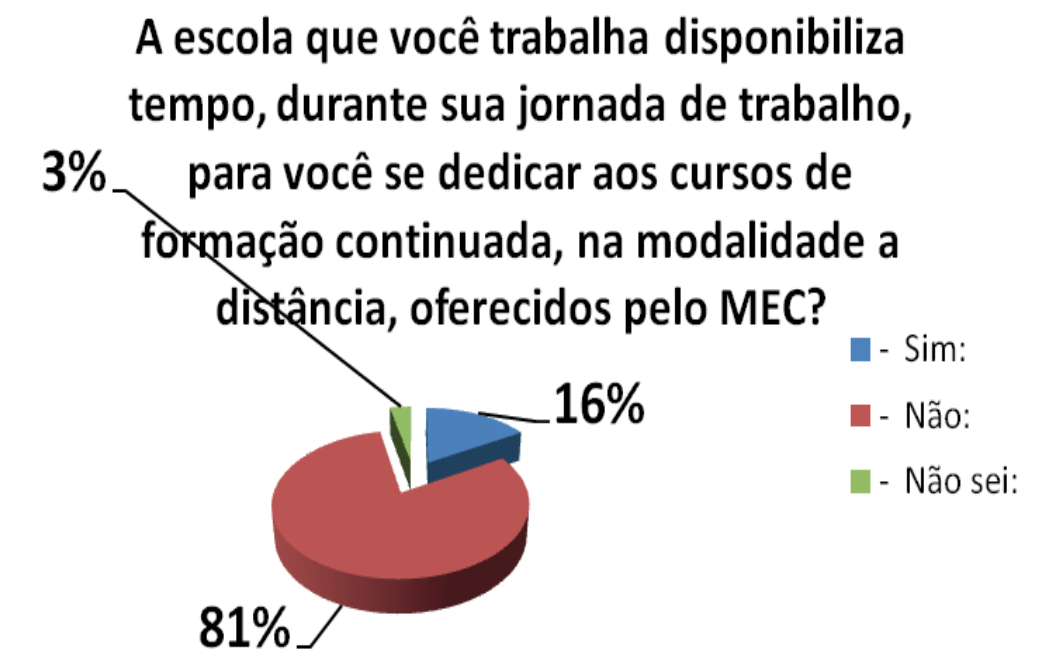

Fonte: Pesquisa de Campo 
Referindo-se aos dados acima, $81 \%$ dos sujeitos ressaltam que as escolas onde trabalham não disponibilizam tempo, para se dedicarem aos cursos de formação continuada, o que dificulta uma boa formação continuada.

Acreditamos que a falta de tempo citada pelos cursistas constituise como uma consequência da "intensificação do trabalho" que, segundo Apple (1995), vem acompanhada de dois processos em desenvolvimento, sendo eles: a desqualificação do trabalhador e a separação entre concepção e educação. A partir dessa análise, Fidalgo (2009, p. 139) enfatiza que:

A intensificação do trabalho docente vem se acirrando em virtude tanto da hegemonia da díade neoliberalismo/globalização quanto da implementação do conjunto de reformas educacionais veiculado após a promulgação da Lei de Diretrizes e Bases da Educação (lei 9.394/96). Consequentemente os professores estão vivenciando uma situação de proletarização, enfrentando uma crise profissional, ao mesmo tempo em que são vistos como técnicos e executores reduzidos à tarefa de implementar reformas concebidas de forma verticalizada.

Nessa perspectiva, os professores não são compreendidos como sujeitos do processo educacional, mas como meros objetos das reformas educacionais.

Apesar das críticas que destacam a questão da intensificação do trabalho docente, acreditamos que a EaD constitui-se como uma alternativa para os profissionais participarem de cursos, no qual podem administrar seu próprio tempo, tendo assim possibilidades de maior permanência nos mesmos. "Estamos aqui, porém, interessados em especial em oportunidades virtuais, porque estas podem facilmente adaptar-se aos ritmos individuais e necessidades/condições dos professores" (Demo, 2000, p. 121). Assim, o curso de formação continuada na modalidade EaD contempla fatores de relevância para professores que querem continuar a sua formação.

Partindo dos dados obtidos nos questionários analisados, percebemos que o Curso Aperfeiçoamento em Atendimento Educacional Especializado para Pessoas Surdas proporcionou suporte necessário para a formação dos sujeitos acerca da inclusão escolar. O AVA conseguiu, segundo os cursistas, dar oportunidade para que os mesmos construíssem sua própria autonomia, buscando descobrir suas potencialidades, no processo de aprendizagem.

É notório que a EaD é uma modalidade de ensino que vem ganhando espaço, pois proporciona condições aos profissionais de continuar buscando uma formação permanente. Muitos profissionais possuem uma carga horária dupla de trabalho, assim, não têm condições para se 
dedicarem no processo presencial de formação continuada permanente. Dessa forma, a EaD apresenta possibilidades para esses profissionais adquirirem novos conhecimentos.

Nessa pesquisa fica evidente que os profissionais, de modo geral, acreditam que a EaD é uma modalidade de ensino que possui aspectos positivos, pois possibilita a interação entre os participantes, dá condições para o profissional buscar aprender a aprender, ter autonomia diante seu próprio conhecimento, sanar dúvidas, compartilhar conhecimentos, ideias e experiências.

\section{Algumas considerações}

Os estudos demonstram que a inclusão é um processo, no qual exige posicionamento acerca das concepções e práticas dos profissionais que atuam nas instituições escolares. É um processo de busca constante que necessita de diversas transformações dentro de um movimento que consiste primeiramente no respeito ao próximo.

Nessa direção, a Educação Inclusiva é centrada na questão da diferença, buscando compreender, atender e reconhecer as necessidades dos sujeitos que estão no sistema educacional.

Infelizmente, o sistema regular de ensino ainda precisa ser mais bem adaptado e pedagogicamente transformado para atender os alunos de forma inclusiva. No entanto, é necessário, antes de tudo, tornar real os requisitos para que a escola seja realmente inclusiva e não, excludente. Buscamos conquistar uma educação de qualidade, que garanta a permanência de todos na escola com a construção de conhecimentos, e que possibilite o acesso e a permanência de todos no âmbito escolar.

Ainda encontramos diversos desafios diante de uma sociedade excludente que peca por não acreditar nessa modalidade, mesmo em um contexto educacional de transformação em que a educação busca novas formas no processo educacional.

Mediante aos questionários analisados nesta pesquisa, percebemos que os cursistas avaliam de forma positiva o Curso de Aperfeiçoamento em Educação Especial e Atendimento Educacional Especializado para Pessoas Surdas - Turma II, constituindo-se, então, uma oportunidade de muitos profissionais vivenciarem uma formação continuada permanente sobre inclusão escolar, mesmo diante do cenário crítico da educação como, por exemplo, a falta de tempo de alguns profissionais de área. Sendo assim, a EaD, constitui-se como uma nova forma de pensarmos o trabalho com as diversas tecnologias que estão sendo inseridas em nossa sociedade. 


\section{Referências}

APPLE, M. Trabalho docente e textos: Economia política das relações de classe e de gênero na educação. Porto Alegre: Artmed, 1995.

BEHAR, P A; LEITE, S. M. The Virtual Learning Environment Project of Long Distance Education and Technology. EUA, v. 15, n.2, p. 159-167, 2006.

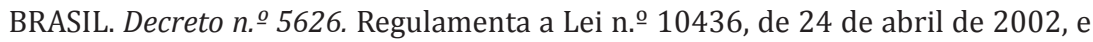
o artigo 18 da Lei n. $\stackrel{0}{10.098}$, de 19 de dezembro de 2000. Brasília: SEESP/MEC, 2005.

MEC. SEESP. Política Nacional de Educação Especial na Perspectiva da Educação Inclusiva. Brasília, DF, MEC, 2007.

CARVALHO, R.E. A nova LDB e a educação especial. Rio de Janeiro: WVA, 1997.

Temas em educação especial. Rio de Janeiro: WVA, 1998.

CARVAlHO, R.E. Dez anos depois da Declaração de Salamanca. Disponível em: <http://cape.edunet.sp. gov.br/textos/eventos/2.doc>. Acesso em: 20 out. 2010.

DEMO, P. Formação permanente e tecnologias educacionais. Petrópolis, RJ: Vozes, 2000 .

FIDALGO, F.; OLIVEIRA, M. A. M.; FIDALGO, N. L. R. Trabalho docente, formação continuada e tecnologias. In: FIDALGO, F; OLIVEIRA, M. A. M.; FIDALGO, N. L. R.(Orgs.). A intensificação do trabalho docente: tecnologias e produtividade. Campinas, SP: Papirus, 2009.

FONSECA, V. Educação Especial. Porto Alegre: Artes Médicas. 1995.

GOLDFELD, M. A Criança Surda: Linguagem e Cognição numa perspectiva sóciointeracionista. São Paulo: Plexus, 2001.

GLAT, R.\& OLIVEIRA, E. da S. G. Adaptações Curriculares. In: Relatório de consultoria técnica, projeto Educação Inclusiva no Brasil: Desafios Atuais e Perspectivas para o Futuro, 2003. Disponível em: <http://www.cnotinfor.pt/inclusiva>. Acesso em: dez. 2010.

MAGGIO, M. O tutor na Educação a Distância. In: LITWIN, E. Educação a distância: temas para o debate de uma nova agenda educativa. Porto Alegre: Artmed Editora, 2001.

MANTOAN, M. T. E. A integração de pessoas com deficiência: contribuições para uma reflexão sobre o tema. São Paulo: Memnon Editora SENAC, 1997.

2003.

Inclusão escolar: 0 que é? Por quê? Como fazer? São Paulo: Ed. Moderna,

MENDES, E. G. A radicalização do debate sobre inclusão escolar no Brasil. In: Revista Brasileira de Educação. v. 11, n. 33, set./dez. 2006.

PADILHA, A. M. O que fazer para não excluir Davi, Hilda, Diogo... In: GÓES, M. C. R.; LAPlAne, A. L. F. (Org). Políticas e Práticas de educação inclusiva. Campinas, SP: Autores Associados, 2004. 
SASSAKI, R. K. Inclusão: construindo uma sociedade para todos. Rio de Janeiro: WVA, 1997.

SKLIAR. C. B. Seis perguntas sobre a questão da inclusão de como acabar de vez por todas com as velhas e novas fronteiras em educação. Pro-posições, Revista da Faculdade de Educação, Campinas, SP, v.2, n.2/3, p. 11-21, jul./ nov. 2001. 
Sobre o livro

$\begin{aligned} \text { Formato } & 16 \mathrm{~cm} \times 23 \mathrm{~cm} \\ \text { Tipologia } & \text { Cambria } \\ & \begin{aligned} \text { Franklin Gothic Medium } \\ \text { Franklin Gothic Demi }\end{aligned} \\ & \\ \text { Papel } & \text { Sufite } 75 \mathrm{~g}\end{aligned}$


Este livro é resultado do trabalho de um grupo de profissionais preocupados com a formação docente e a escolarização das pessoas com deficiência, transtornos globais do desenvolvimento e altas habilidades/superdotações. Os autores são membros do Grupo de Estudos e Pesquisa em Políticas Práticas em Educação especial - GEPEPES, nas linhas de Educação a Distância e Educação Especial, de Educação de Pessoas Surdas e Ensino de Língua Brasileira de Sinais - Libras, e de Políticas e Educação Especial. A publicação é também parte do compromisso assumido junto ao Ministério da Educação por meio da Secretaria de Educação Continuada, Alfabetização, Diversidade e Inclusão/Diretoria de Políticas Pedagógicas de Educação Especial (MEC/SECADI/DPEE), como parte das atividades de pesquisa realizadas nas edições do Curso de Extensão em Aperfeiçoamento em Atendimento Educacional Especializado para Surdos.

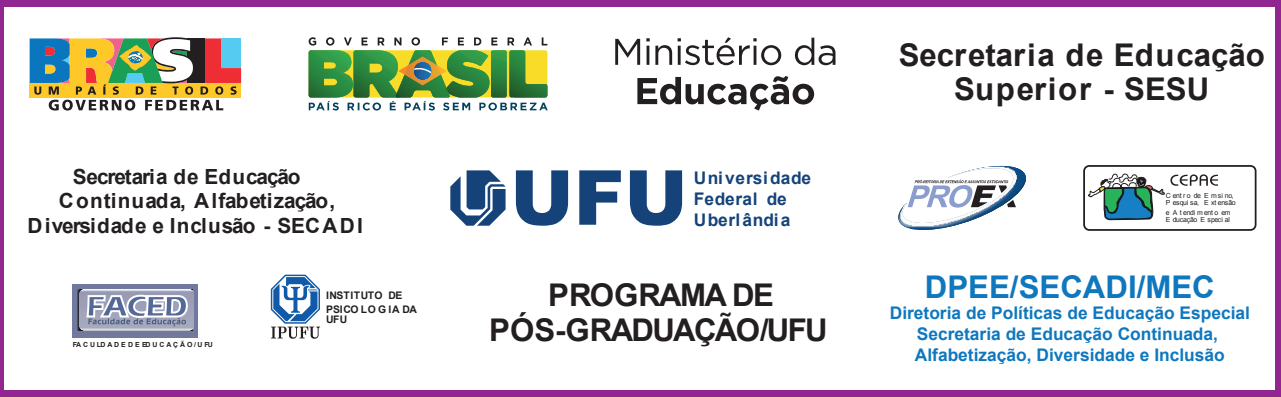

